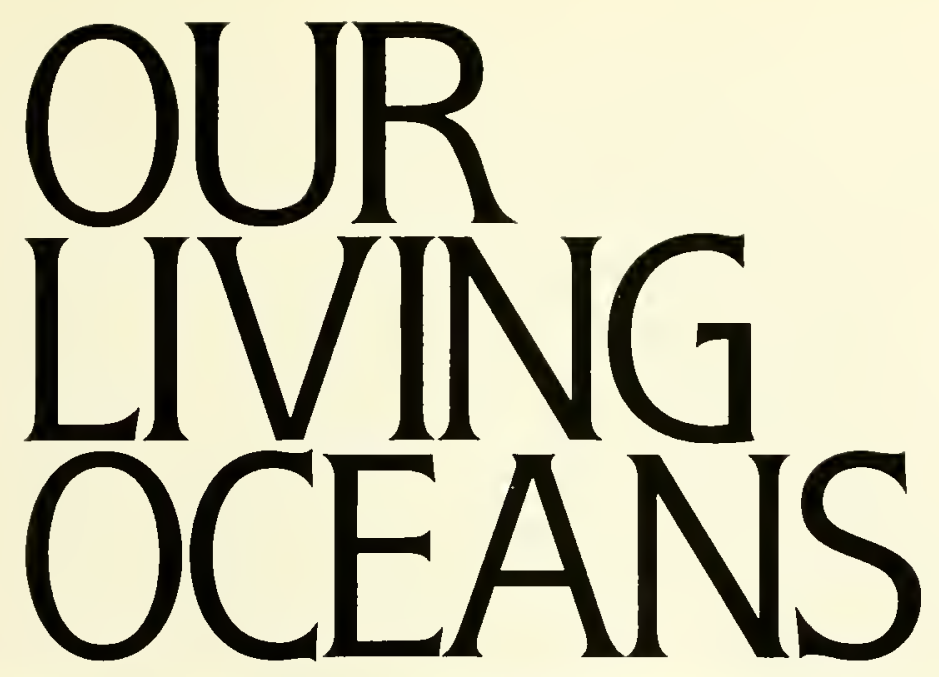

THE FIRST

ANNUAL

REPORT ON

NOAA.

THE STATUS

OF U.S. LIVING

MARINE

RESOURCES

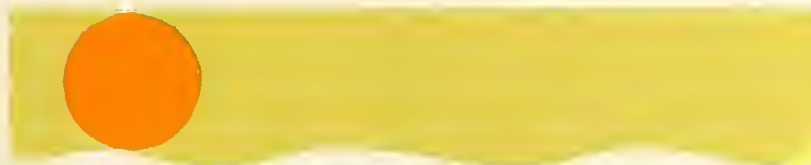

QH

91

Al

07

1991

Woods Hole Ocearougranhic

TM NMES-

1991

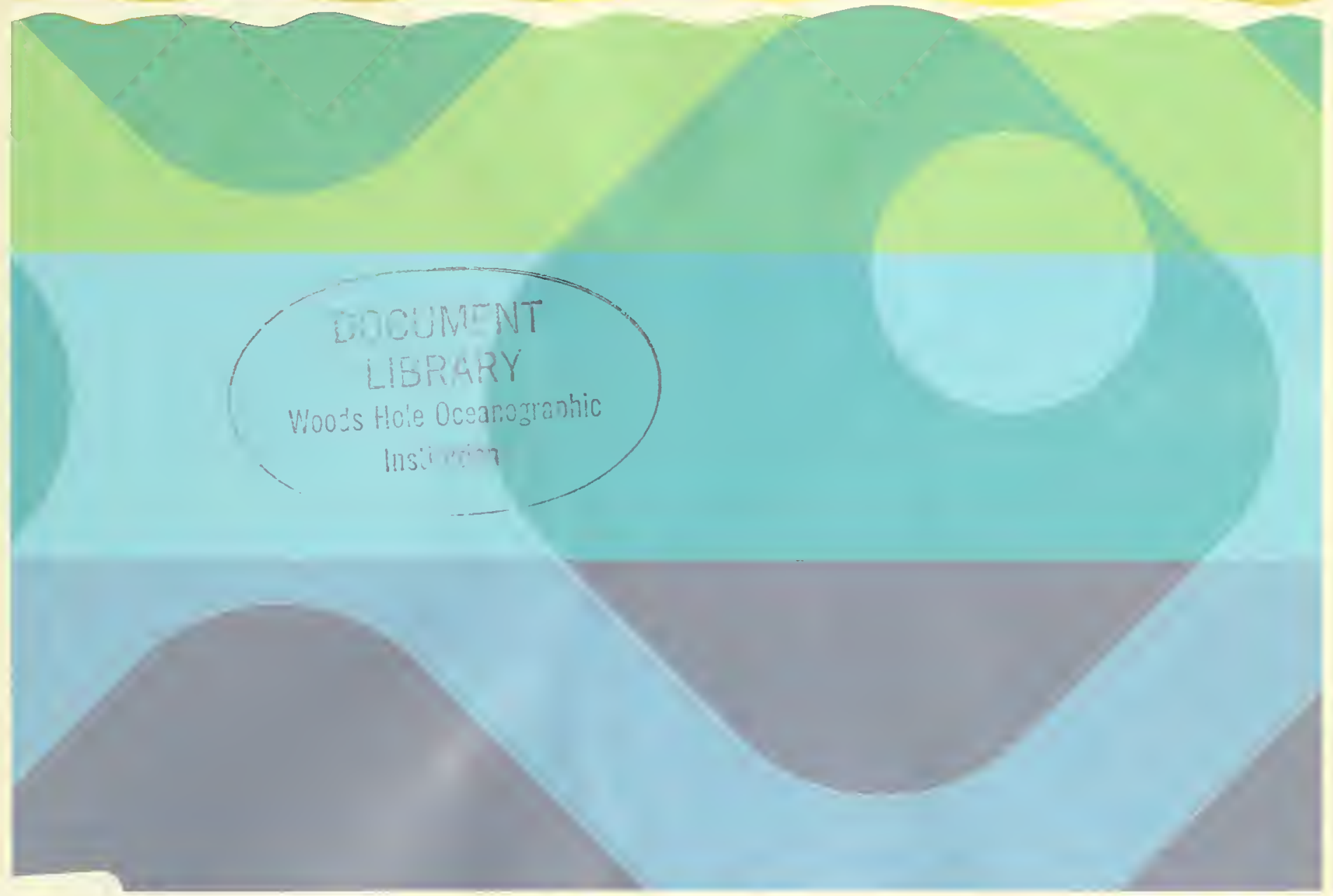





\section{v Preface}

\section{vi Foreword}

\section{Part 1: Overview}

3 introduction

4 Scientific Principles and Terms

7 National Overview: Status and Potential of U.S. Living Marine Resources

\section{Part 2: Unit Synopses}

23 Unit 1: Northeast

Demersal Fisheries

27 Unit 2: Northeast Pelagic Fisheries

29 Unit 3: Atlantic Anadromous Fisheries

32 Unit 4: Northeast Invertebrate Fisheries

36 Unit 5: Atlantic Highly Migratory Pelagic Fisheries

39 Unit 6: Atlantic Shark Fisheries

41 Unit 7: Atlantic Coastal Migratory Pelagic Fisheries

43 Unit 8: Atlantic/Gulf of Mexico/Caribbean Reef Fish Fisheries
16 Issues of National Concern

19 Strategy for the Future 47 Unit 9: Southeast Drum and
Croaker Fisheries

49 Unit 10: Southeast Menhaden and Butterfish Fisheries 52 Unit 11: Southeast/Caribbean
Invertebrate Fisheries

56 Unit 12: Pacific Coast Salmon Fisheries

59 Unit 13: Alaska Salmon Fisheries

62 Unit 14: Pacific Coast and Alaska Pelagic Fisheries

67 Unit 15: Pacific Coast Groundfish Fisheries 
72 Unit 16: Western Pacific Invertebrate Fisheries

75 Unit 17: Western Pacific Bottomfish and Armorhead Fisheries

78 Unit 18: Pacific Highly Migratory Pelagic Fisheries

83 Unit 19: Alaska Groundfish Fisheries

89 Unit 20: Alaska Shellfish Fisheries
93 Unit 21: Nearshore Fisheries

98 Unit 22: Atlantic Marine Mammals

102 Unit 23: Pacific Marine Mammals

109 Unit 24: Sea Turtles

\section{Part 3: Appendices}

113 Appendix 1:

Acknowledgments

114 Appendix 2: Fishery

Management Councils and

Fishery Management Plans
116 Appendix 3: Common and Scientific Names of Species Covered in This Report 
This report is the most comprehensive status review of U.S. living marine resources ever made. It provides the available scientific information on the health and abundance of important marine populations based on the latest assessments available in mid-1991. It addresses most marine and anadromous species having commercial, recreational, and ecological significance. Besides finfish and shellfish, it includes marine mammals, sea turtles, and corals under purview of the U.S. Department of Commerce's National Oceanic and Atmospheric Administration (NOAA). Additional information is provided in separate reports for five distinct regions: Northeast Atlantic, Southeast Atlantic and Gulf of Mexico, West Coast, Hawaii and the Pacific Islands, and Alaska.

$A$ report of this magnitude would not be possible without the long-term commitment of NOAA's National Marine Fisheries Service (NMFS) to resource assessment studies including resource surveys, collection of recreational and commercial harvest statistics, and population biology and ecological research. More than 60 NMFS scientists prepared sections of this report (Appendix 1), and many other NMFS personnel contributed indirectly. 
It is appropriate that NOAA's first report on the status of the Nation's living marine resources be released during the 200th anniversary year of Thomas Jefferson's 1791 communication to the First U.S. Congress, transmitting "... the Report on the Subject of the Fisheries of the United States...." Then, as now, the economic welfare of our fisheries and the biological health of the marine life and habitat on which these fisheries depend, remain a continuing and legitimate concern of the Federal government.

Our vision is to restore the ocean's wealth of living marine resources through major strategic initiatives to:

1) Rebuild U.S. fisheries by reducing overfishing and maintaining currently productive fisheries;

2) Protect and conserve marine mammals, sea turtles, and other endangered or threatened species;
3) Protect and restore coastal and estuarine fishery habitats; and

4) Improve seafood safety.

Through these initiatives, NMFS will set the standard for management of the ocean's renewable resources.

To support these goals, we shall update and present a new national status report each fall to NOAA's many constituents. In this way the vital information on the health of the nation's marine resources will be available to all who share the common purpose of conserving and wisely using our living ocean heritage.

William W. Fox, Jr., Ph.D.

Assistant Administrator for Fisheries National Oceanic and

Atmospheric Administration

November 1991 



\section{OUR LIVING \\ MARINE RESOURCES}

The living marine resources (LMR's) of the United States are an extremely valuable heritage. In recent years, the marine fishing industries, both seafood and recreation, and allied enterprises have contributed over $\$ 24$ billion annually to the U.S. economy. In addition, the opportunity to fish recreationally adds to the quality of life for about 17 million Americans. Also, there are economic benefits from subsistence fishing, aquaculture, and recreational viewing (e.g., whale watching) industries, as well as the intangible assets accruing from the protection of marine mammals and endangered species.

\section{OLDEST FEDERAL CONSER VATION COMMISSION}

Spencer F. Baird was named the Nation's first Commissioner of Fish and Fisheries in 1871.
It has long been recognized that conservation and wise use of LMR's require a sound scientific basis. In 1871, the U.S. Congress established the U.S. Commission of Fish and Fisheries, predecessor of the NMFS, ". . . to investigate the reasons for the decline in coastal fish stocks off southern New England and to recommend corrective measures.... From its inception, the Commission made broad scientific advances in marine biology and oceanogra. phy, building on the vision of its first Commissioner, Spencer F. Baird, an emi-

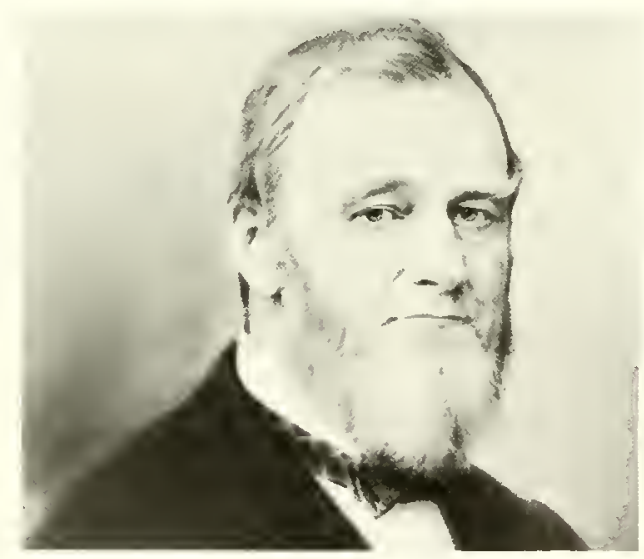

nent scientist and also Secretary of the Smithsonian Institution. Today, NMFS carries on a 120-year tradition of scientific service to the Nation; however, its mission is more complex than ever.

In the last 20 years, NMFS' responsibilities have increased exponentially as a result of more than 100 legislative acts and international conventions and treaties. NMFS now has management responsibility for most U.S. living marine resources. In particular, the Agency is responsible for: 1) Conservation and management of the fishery resources in the 200-mile U.S. Exclusive Economic Zone (EEZ) under the Magnuson Fisheries Conservation and Management Act (Magnuson Act) and 2) protection of marine mammals and threatened and endangered species under the Marine Mammal Protection Act (MMPA) and the Endangered Species Act (ESA), respectively. The Magnuson Act established eight Regional Fishery Management Councils (Councils) which are partners with NMFS in the preparation of Fisheries Management Plans (FMP's). The Councils and FMP's are listed in Appendix 2.

NMFS prepares many specialized scientific reports (about 800 in 1990) to support Federal management responsibilities and its scientific mission. This national report has the broader purpose of disseminating current information on the status of U.S. LMR's to those interested in it. It can be viewed as a "report card" on how well the Nation is fulfilling its stewardship responsibility. In this sense, its intent is analogous to Thomas Jefferson's first report to Congress (see Foreword), written two centuries ago.

This report is presented in three major sections, and the first, which includes this Introduction, provides an overview of the status of LMR's. Additionally, it discusses several issues of national concern (e.g. bycatch, overutilization, etc.) that apply to many U.S. fisheries. It also provides some background on the scientific content of the remainder of the report. The second section reviews in greater detail the status of our living marine resources in 24 separate units. These Unit Synopses describe species that are linked geographically, ecologically, and/or by characteristics of their harvesting operations. Appendices, the third section, list contributing authors and editors, Regional Fishery Management Councils and Fishery Management Plans, and the scientific and common names of the species covered in this report. 
4

\section{INTRODUCTION}

A POPULATION IS a group of animals that are genetically related owing to interbreeding. Ideally, populations should be considered distinct groups for fishery management purposes. But it is difficult to determine which individuals of a species form a population, and it may not be practical to manage them as a population. Thus, this report uses the term "population" to identify interbreeding biological groups. The term "stock" is used to identify groups of animals for management purposes.
Fish abundance or population size can be expressed as either the number of fish or the total fish weight (or "biomass"). Fish abundance is determined by growth of the individual fish and the addition or recrultment of new generations of young fish (i.e., "recruits") to the population. Those gains must then be balanced against removals from the population by fishing (called fishing mortality) and natural causes such as predation, starvation, and disease (called natural mortality). In stock assessment work, fish removals are commonly expressed in terms of rates within a time period. The fishing mortality rate is a function of fishing effort (the amount of fishing gear and the time spent fishing).

Surplus production (or just "production") is the weight (biomass) of fish that can be removed by fishing without causing a change in population size. It is calculated as the sum of the growth in weight of individuals in a population, plus the addition of biomass from new recruits, minus the bio- mass of animals lost to natural mortality.

The production rate is expressed as a proportion of the population size or biomass. The production rate is highly variable owing to environmental fluctuations, predation, and other biological interactions with other populations. On average, production rate decreases at low and high population sizes. Thus, surplus production tends to be low at the extremes of population size (i.e., where biomass or production rate is (low). It is more likely to be high at some intermediate level of population biomass. But, on average, biomass decreases as the amount of fishing effort increases. This means there is a relationship between average production and fishing effort. The relationship is known as the production function. A hypothetical production function is shown in Figure 1. Production functions are the basis for three important terms used in this report: Long-term Potential Yield (LTPY), Current Potential Yield (CPY), and Recent Average Yield (RAY).
LONG-TERM POTENTIAL YIELD (LTPY)
In the best professional judgment of NMFS scientists, LTPY is the maximum long-term average yield (catch) that can be achieved through conscientious stewardship, by controlling the fishing mortality rate to maintain the population at a size that would produce a high average yield or harvest.

\section{CURRENT POTENTIAL} YIELD (CPY)
The yield or catch that can be taken during any particular period depends on the existing fish population size and current production rate. The yield may be either greater than or less than LTPY, and this report uses the term "current potential yield." In the best professional judgment of NMFS scien- tists, CPY is the yield that will maintain the current population level (biomass) or stimulate a trend toward a population that will produce the LTPY. CPY is frequently estimated by applying the fishing mortality associated with LTPY to the current population size.

\section{RECENT AVERAGE YIELD (RAY)}

To document the actual fish catches, this report employs the term "recent average yield" (RAY). This is the reported fishery landings averaged for the 3-year period, 1988-90. 
Figure 1.-Hypothetical Production Function. In this case, the function has a flat region where average production is insensitive to the amount of fishing effort. This occurs for many populations when the effect of growth and natural mortality on production are almost in balance. But eventually excess fishing effort reduces the size of the population to the point where recruitment fails, and production drops precipitously.

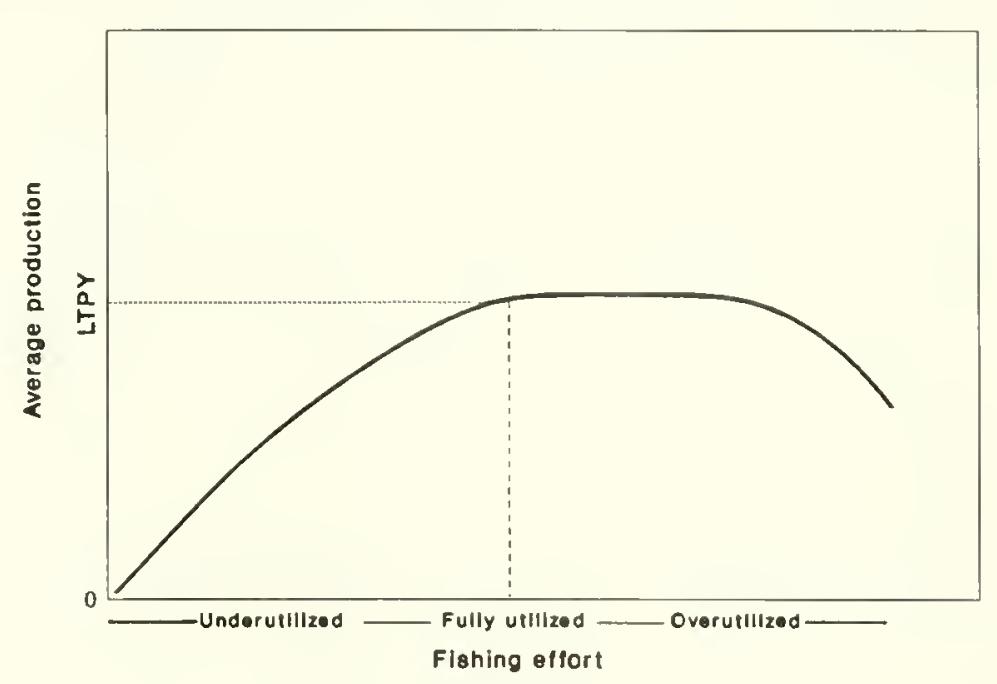

To evaluate the level of use of a fishery resource (i.e., underutilized, overutilized, or fully utilized) we must see how the existing fishing effort compares with the effort necessary to achieve LTPY. To do this, it is useful to compare CPY with LTPY and to compare RAY with both.

In this report, a fishery resource is defined as fully utilized when the amount of fishing effort is about equal to the effort needed to achieve LTPY. For fully utilized fisheries, the RAY and CPY are usually about equal. In most cases, LTPY and CPY are also about equal, but they may differ as a result of production variability.

A fishery resource is considered overutilized when more fishing effort is used than is necessary to achieve LTPY. When RAY is greater than CPY, and CPY is less than LTPY, overutilization is indicated. Additionally, it is possible for RAY, CPY, and LTPY to be about equal while the fishery resource is overutilized. This occurs when adding more fishing effort adds very little to the catch. In such cases, overutilization may not have an apparent adverse effect on production, but it further reduces the size of the population, and it wastes effort and economic resources.

A fishery resource is termed underutilized when more effort is required to achieve LTPY. This situation is generally indicated when RAY is less than CPY and CPY is greater than LTPY. But there may be exceptions. For example, RAY may be held below CPY and LTPY to compensate for uncertainty in population estimates.

These are some of the factors NMFS considers in determining the degree of utilization of a resource, but they do not give a complete picture. Therefore, the NMFS has used its judgment to classify fishery resources as underutilized, fully utilized, or overutilized whenever there is sufficient information.

This report serves as only one information source on the status of LMR's. Another source is the guidelines set under the Magnuson Act that require FMP's define "overfishing" in a measurable way. Magnuson Act guidelines allow considerable flexibility in the formulation of FMP overfishing definitions. Annual evaluations will determine if fishery resources are overfished according to these definitions. Determinations of the degree of utilization reported in this document are more narrowly based on traditional principles of fisheries science. The terms "overutilization" as used in this document and "overfishing" as used to fulfill Magnuson Act requirements are not interchangeable.

This document also reports on marine mammals and sea turtles that are protected under the Marine Mammal Protection Act (MMPA) and/or the Endangered Species Act (ESA). The same scientific principles apply to the population dynam- 


\section{... Scientific Principles and Terms}

6

\section{... EVALUATING FISHERY RESOURCE LEVELS}

ics of these protected species, but the terminology of underutilized, fully utilized, and overutilized does not apply. Instead, marine mammals are referred to as depleted when their population size is below the level of maximum net production (i.e., analogous to LTPY for a fishery resource), which is often referred to as the optimum population size. Protected species are also classified as "threatened" or "endangered" under the ESA. A species is considered threatened if it is likely to become an endangered species in the foreseeable future throughout a significant portion of its range. A species is considered endangered if it is in danger of extinction throughout a significant portion of its range.
Marine fisheries research has long been necessary. Here (top photo) Spencer Baird, first U.S. Fish Commissioner, shoves off on a nearshore collecting trip off Woods Hole, Mass. His assistant, and later second U.S. Fish Commissioner, George Brown Goode, sits in the bow. Today marine fisheries research is conducted at sea with modern NOAA research vessels like the Miller Freemon (bottom, PMC/NOAA photo).
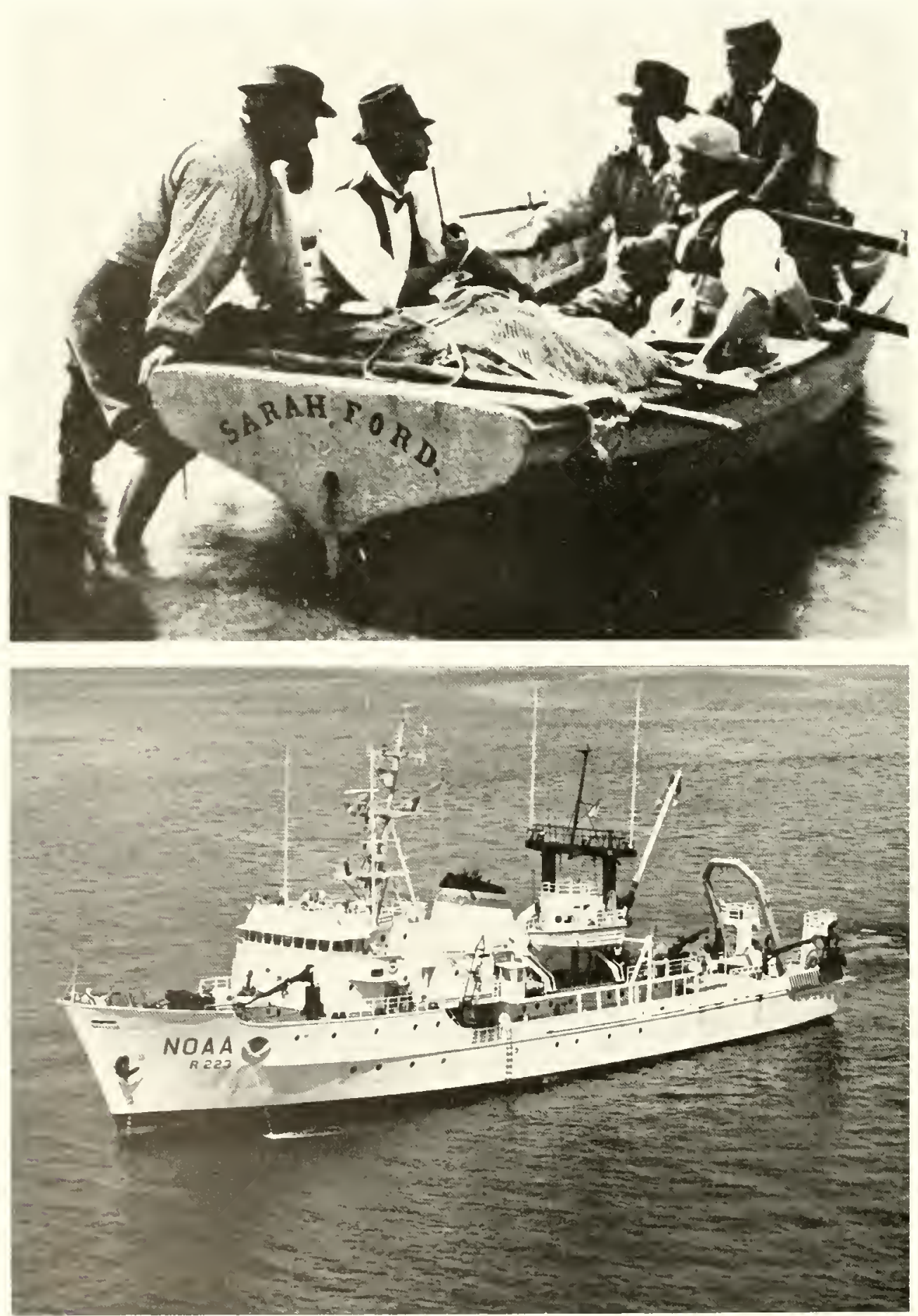


\section{INTRODUCTION}

The LTPY of all U.S. fishery resources (Table 1 ) is conservatively estimated at 8.9 million metric tons ( $t$ ). This does not include the 11.8 million salmon on the west coast which have traditionally been reported in thousands of fish (Unit 12). The Food and Agriculture Organization of the United Nations (FAO) estimates the upper limit of the world's annually sustainable yield of marine and freshwater fish at about 100 million $t$. Therefore, the long-term potential U.S. marine fish harvest is about $9 \%$ of the total world potential.

Bottom dwelling "groundfish" make up $61 \%$ of the total U.S. LTPY, while highly migratory and coastal pelagic species constitute $30 \%$. The remaining $9 \%$ is almost equally divided between anadromous and nearshore finfishes and the invertebrate fishery resources. Three fishery unitsAlaska groundfish (Unit 19), Pacific tunas and billfish (Unit 18), and Southeast menhaden and butterfish (Unit 10)-account for $69 \%$, or 6.1 million $\mathrm{t}$, of the national LTPY.

The estimate of the total current potential yield for the Nation's fishery resources is virtually equal to the LTPY (both were 8.9 million $\mathrm{t}$ ). But there are important differences among regions, units, and individual stocks. For example, LTPY exceeds CPY by more than $125,000 t(31 \%)$ for New England groundfish, whereas CPY exceeds LTPY by $280,000 \mathrm{t}(57 \%)$ for Gulf of Alaska groundfish. In most cases where LTPY is greater than CPY, the long-term potential can only be achieved when the population is rebuilt. In those cases where CPY is greater than LTPY, harvesting at the CPY level cannot be sustained indefinitely.

The total U.S. RAY is 6.4 million $t$, including recreationally caught fish. This value is higher than the catch reported in the NMFS publication, "Fisheries of the United States." The discrepancy is largely due to the exclusion of the high seas fisheries
Table 1.-Recent average, current potential, and long-term potential yields of U.S. LMR's in metric tons $(t)$.

Unit and fishery
1. Northeast demersal
2. Northeast pelagic
3. Atlantic anadromous
4. Northeast invertebrate
5. Atlantic highly migratory pelagic
6. Atlantic sharks
7. Atlantic coastal migratory pelagic
8. Atlantic/Gulf of Mexico/Caribbean reef fish
9. Southeast drum and croaker
10. Southeast menhaden and butterfish
11. Southeast/Caribbean invertebrate
12. Pacific coast salmon
13. Alaska salmon
14. Pacific coast and Alaska pelagic
15. Pacific coast groundfish
16. Western Pacific invertebrate
17. Western Pacific bottomfish and armorhead
18. Pacific highly migratory pelagic
19. Alaska groundfish
Eastern Bering Sea
Gulf of Alaska
Pacific halibut (less Canada)
20. Alaska shellfish
21. Nearshore
Total

Percent of LTPY
LTPY

533,500

470,000

3,979

67,700

271,063

9,730

28,283

$41,404^{\circ}$

$75,934^{\prime}$

$1,177,000$

126,632

$11,806^{3}$

270,258

264,100

357,773

628

2,800

$1,649,928$

$3,295,700$

$(2,784,800)$

$(493,600)$

$(17,300)$

87,480

$\frac{231,225}{8,890,317}$

CPY

408,000

571,000

3,979

104,700

222,569

7,630

20,980

$28,065^{2}$

$28,808^{2}$

957,000

120,025

$11,806^{3}$

270,258

211.100

308,738

402

801

$1,569,261$

$3,728,700$

$(2,926,100)$

$(773,600)$

$(29,000)$

87,480

231,225

$8,877,721$

$99.9 \%$
228,237

176,700

3.979

95,300

226,065

9,530

14,881

28,366

25,808

922,000

120,585

$11,268^{3}$

284,847

102,000

264,946

580

571

$1,599,261$

$2,002,100$

$(1,790,100)$

$(177,600)$

$(34,400)$

87,480

$\frac{231,225}{6,424,461}$

$72.3 \%$

\footnotetext{
'Undereslımate

${ }^{2}$ Overestimate

${ }^{3}$ Thousands of fish.

${ }^{4}$ Not Including Unit 12
} 
8

The globally distributed yellowfin tuna supports fisheries in the Atlantic, Pacific, and Indian Oceans.

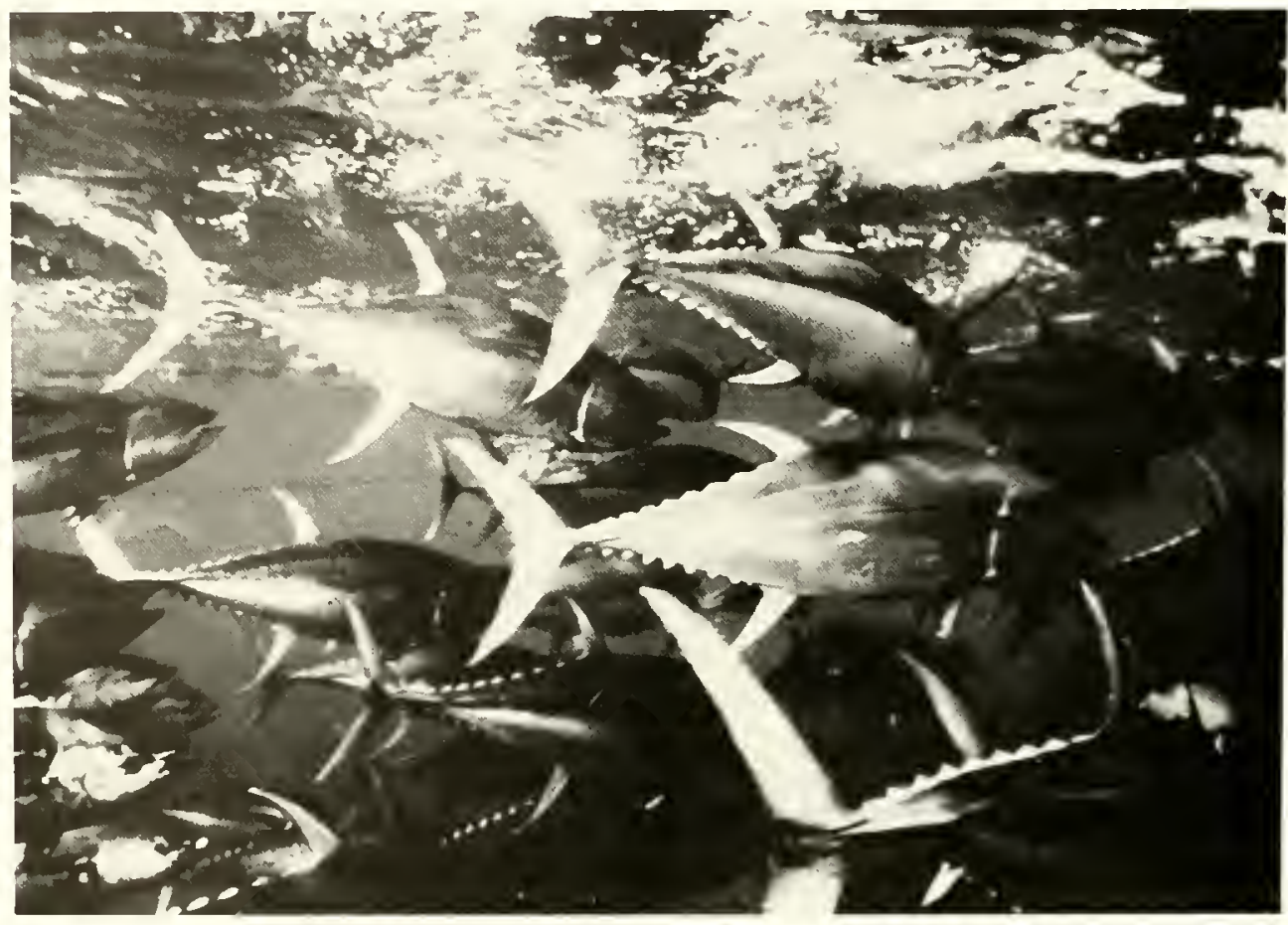

\section{... INTRODUCTION}

catch landed outside the continental U.S. (e.g., Pacific tunas) from "Fisheries of the United States." RAY (combined commercial and recreational fisheries) for the U.S. represents a little more than $6 \%$ of the recent world catch. In recent years, the U.S. has ranked about sixth among major fishing nations, following the USSR, China, Japan, Peru, and Chile.

The recreational finfish catch on the Atlantic and Gulf coasts was estimated at 234 million fish, or $65,000 \mathrm{t}$, in 1990; for the west coast it was estimated at 41 million fish, or $13,000 \mathrm{t}$, for 1989 (the last year that data are available). This catch total is exclusive of Pacific salmon, which historically has composed about $2 \%$ of the entire west coast recreational catch.

The RAY is $72 \%$ of the national CPY and LTPY. While this comparison indicates that there is potential for the U.S. to increase its fishery yields, the following factors need to be considered in interpreting these results:

1) Estimates of LTPY and CPY are sometimes imprecise; therefore, harvest levels may be set conservatively to reduce the risk of depleting fishery resources (e.g., Alaska's walleye pollock).

2) Increasing the yield will result in a reduction in abundance, catch rates, and size of fish, which may adversely affect some users of the resource (e.g., anglers who desire a high catch rate and/or large fish).

3) There are limited markets for in creased landings of several species for which RAY is less than CPY and LTPY (e.g., dogfish off New England and arrowtooth flounder off Alaska).

4) Comparison of aggregate value of LTPY, CPY, and RAY masks the fact that the recent yield for many species exceeds the current potential, and, as noted, the current potential is lower than the longterm potential as a result of overutilization and resource depletion (e.g., Georges Bank haddock).

Brief regional summaries of potential yields and the status of fisheries resources, as well as marine mammals, and threatened and endangered sea turtles, are given below. 


\section{NORTHEAST U.S. LMR'S}

A summer flounder and associated species (butterfish, Loligo squid, and sand lance) taken in research vessel surveys off the New England coast.
The fisheries of the northeast region (Units $1,2,3$, and 4) annually contribute about $25 \%$ of the value and $18 \%$ of the volume of the Nation's commercial fisheries. In 1990 , the total northeast landings were 753,000 $t$, valued at $\$ 857$ million. The category, mixed groundfish, is the most valuable component of the commercial fishery (\$178 million), followed by American lobster (\$151 million) and Atlantic sea scallop (\$147 million). Marine angling is extremely important and contributes an estimated $\$ 1.5$ billion per year to the region's economy.

Northeast finfish and invertebrate fisher- ies have an estimated LTPY of over 1.1 million $t$ (exclusive of resources within state waters such as menhaden, blue crab, oyster, blue mussel, hard clam, etc.), or $12 \%$ of the national LTPY. Recent annual landings in this region have totaled only $500,000 t$-less than half of their long-term potential yield. The large discrepancy between recent landings and potential yield results from overutilization of 18 regional stocks (including most groundfish and flounders) and 7 underutilized stocks (including Atlantic mackerel, squids, and butterfish); 11 species (stocks) are considered fully utilized.

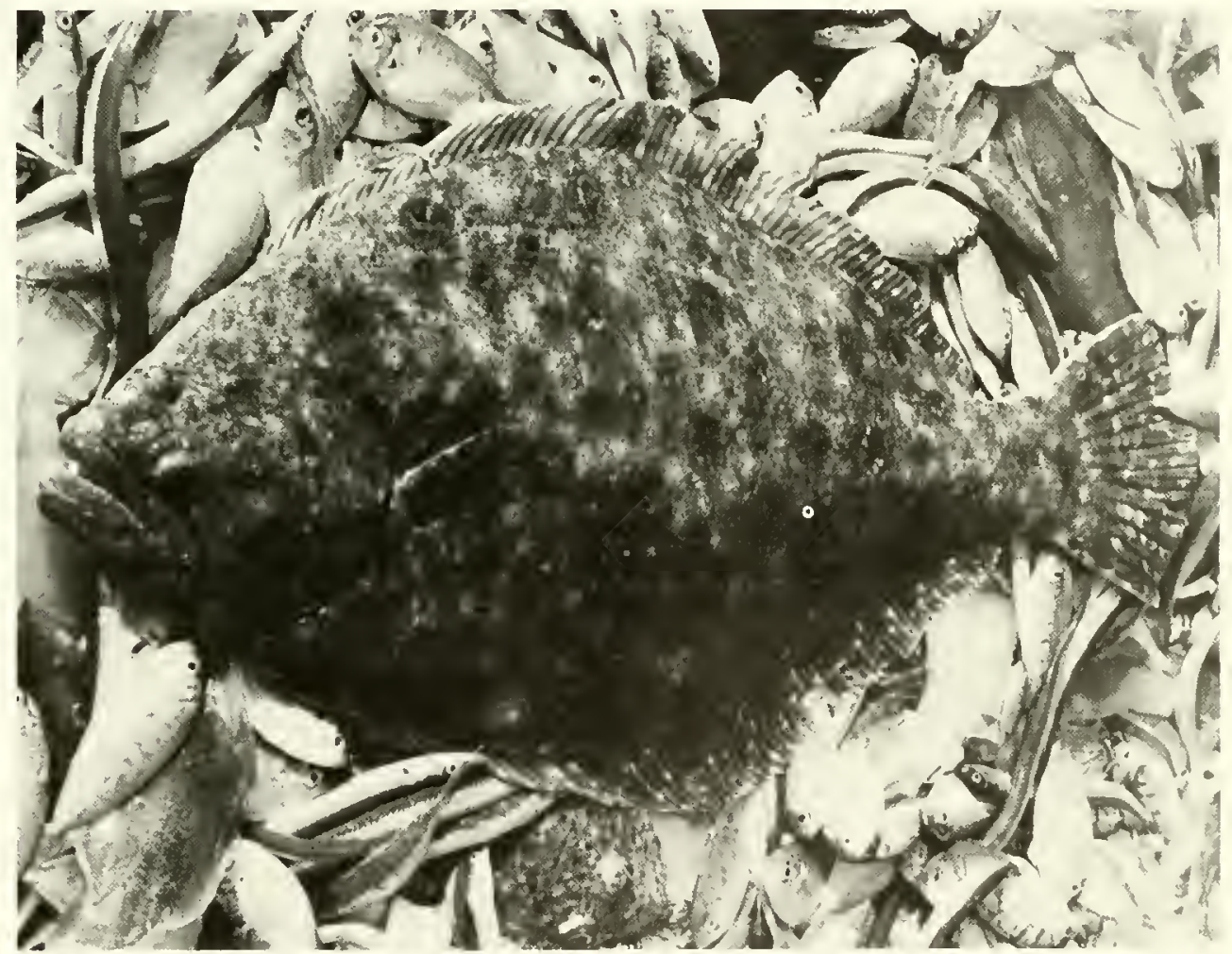

SOUTHEAST U.S. LMR'S
The combined LTPY for southeast Atlantic, Gulf of Mexico and Caribbean LMR's (Units $5,6,7,8,9,10$, and 11 ) is estimated at about 1.4 million $t$ ( $16 \%$ of the national LTPY); recent catches have run about $80 \%$ of CPY and $77 \%$ of LTPY, and $17 \%$ of the U.S. total. Atlantic swordfish and bluefin tuna, many southeast Atlantic snappers and groupers, and Caribbean reef fish have been overutilized and some stocks are at historically low levels. The status of many other reef fish stocks is unknown, but they are likely to be overutilized as well. Individually, these stocks are minor portions of the catch, but, in aggregate, they have supported important recreational and commercial fisheries. The recreationally and commercially important coastal pelagic species (e.g., mackerels, dolphin fish, and cobia) yield only about $53 \%$ of their estimated aggregate LTPY as a result of overutilization. Certain individual stocks are severely depressed, as are Gulf of Mexico king mackerel. 


\section{... National Overview: status and Potential of U.S. Living Marine Resources}

10

... SOUTHEAST U.S. LMR'S

This all-tackle, world record red drum, weighing 94 pounds 2 ounces, was caught off Cape Hatteras, N.C, in 1984.
Currently, all commercially important shrimp species are being harvested at the LTPY level, but they could produce similar yields with considerably less effort if fishing mortality were reduced. The dominant catches are Gulf of Mexico brown, white,

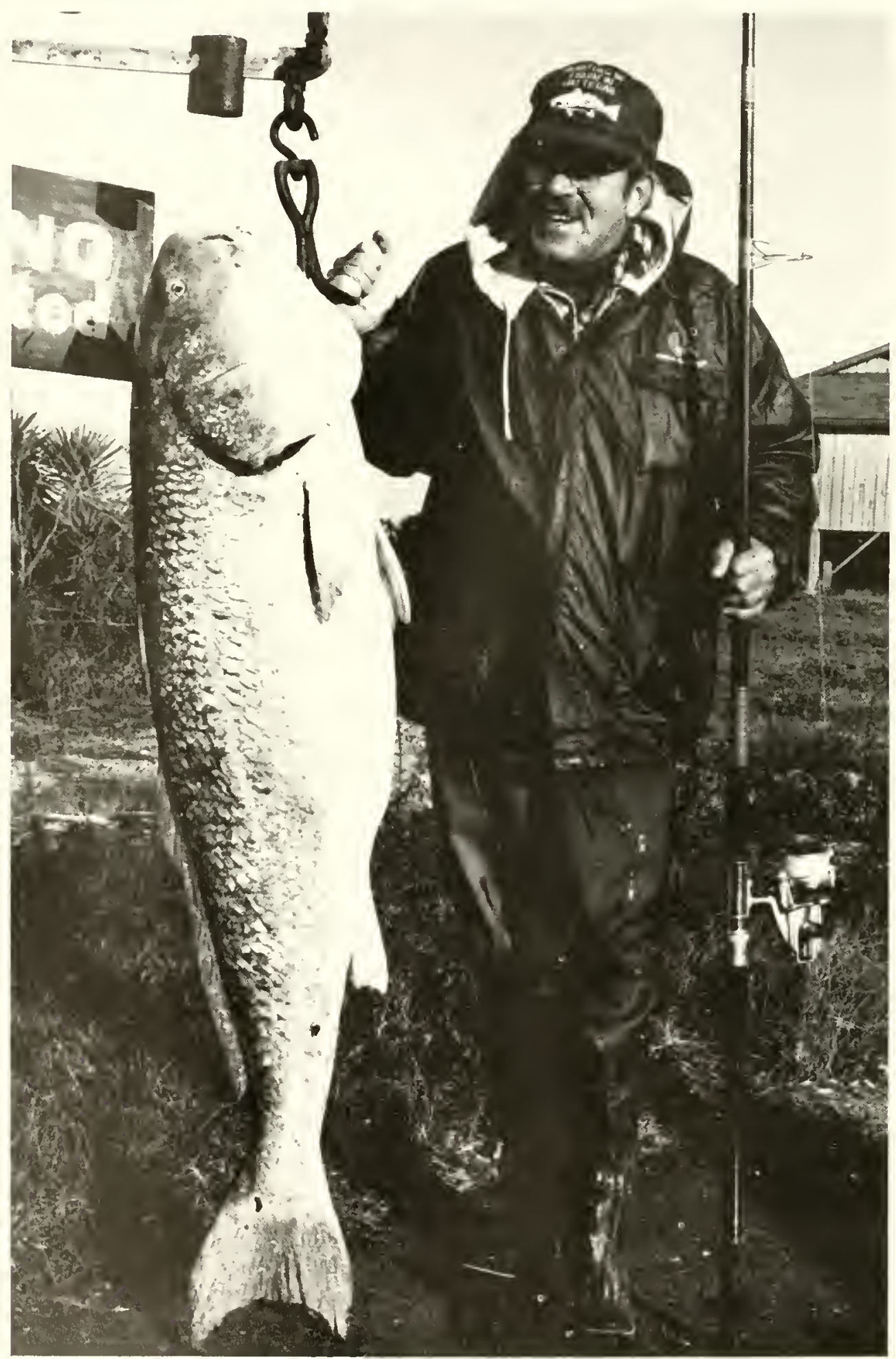

and pink shrimp, which represent $89 \%$ of the total shrimp catch, nationally. In 1990 , those three species produced a total catch of $111,702 \mathrm{t}$, valued in excess of $\$ 405$ million. 


\section{WEST COAST AND WESTERN PACIFIC LMR'S}

West coast, Pacific-wide, and Pacific island fisheries (Units 12, 14, 15, 16, 17, and 18) account for more than 2.2 million $t$ and $25 \%$ of the U.S. LTPY. These include groundfish and northern anchovy (west coast), tuna and billfish (Pacific-wide), and reef and seamount finfish and lobster ( $\mathrm{Pa}$ cific islands).

Underutilized, fully utilized, and overutilized stocks range between 18 and $24 \%$ of the total Pacific coast and western Pacific stocks. Insufficient assessment data exist for 19 stocks ( $36 \%$ of the total), which are assigned an "unknown" status. The large biomasses that existed for most of the long-lived species (sablefish, Dover sole, rockfish) prior to intense fishing have been fished down to the point where these species are fully utilized and the CPY is very close to the LTPY. Stocks of several species of rockfish need to be rebuilt after severe overutilization and poor recruitment. Other species, like jack mackerel and shortbelly rockfish, are presently underutilized for lack of markets. With the exception of yellowfin tuna in the eastern tropical Pacific, virtually all the other 17 stocks in the highly migratory species unit are unassessed for LTPY and CPY. Included are the large pelagic sharks, central western Pacific tunas, swordfish, and albacore and skipjack tuna stocks, Pacificwide.

The total economic value of these resources is conservatively set at $\$ 1.5$ billion. Pacific salmon produce commercial land. ings worth about $\$ 140$ million to west coast fishermen. Conservatively valuing each recreationally caught salmon at $\$ 20.00$ would place the average annual 1988-90 recreational catch of $1,205,000$ fish at over $\$ 24$ million. The Pacific tuna fisheries are valued at more than $\$ 1.3$ billion, and although no estimate is available for billfishes (owing to the variety of species in this category and a large recreational fishery component), the three principal species (swordfish and blue and striped marlins) are all valued in excess of $\$ 2,000 / t$, for both recreational and commercial fisheries. Groundfish commercial landings are valued at $\$ 88$ million.
A large catch of shortbelly rockfish on the Pacific coast.

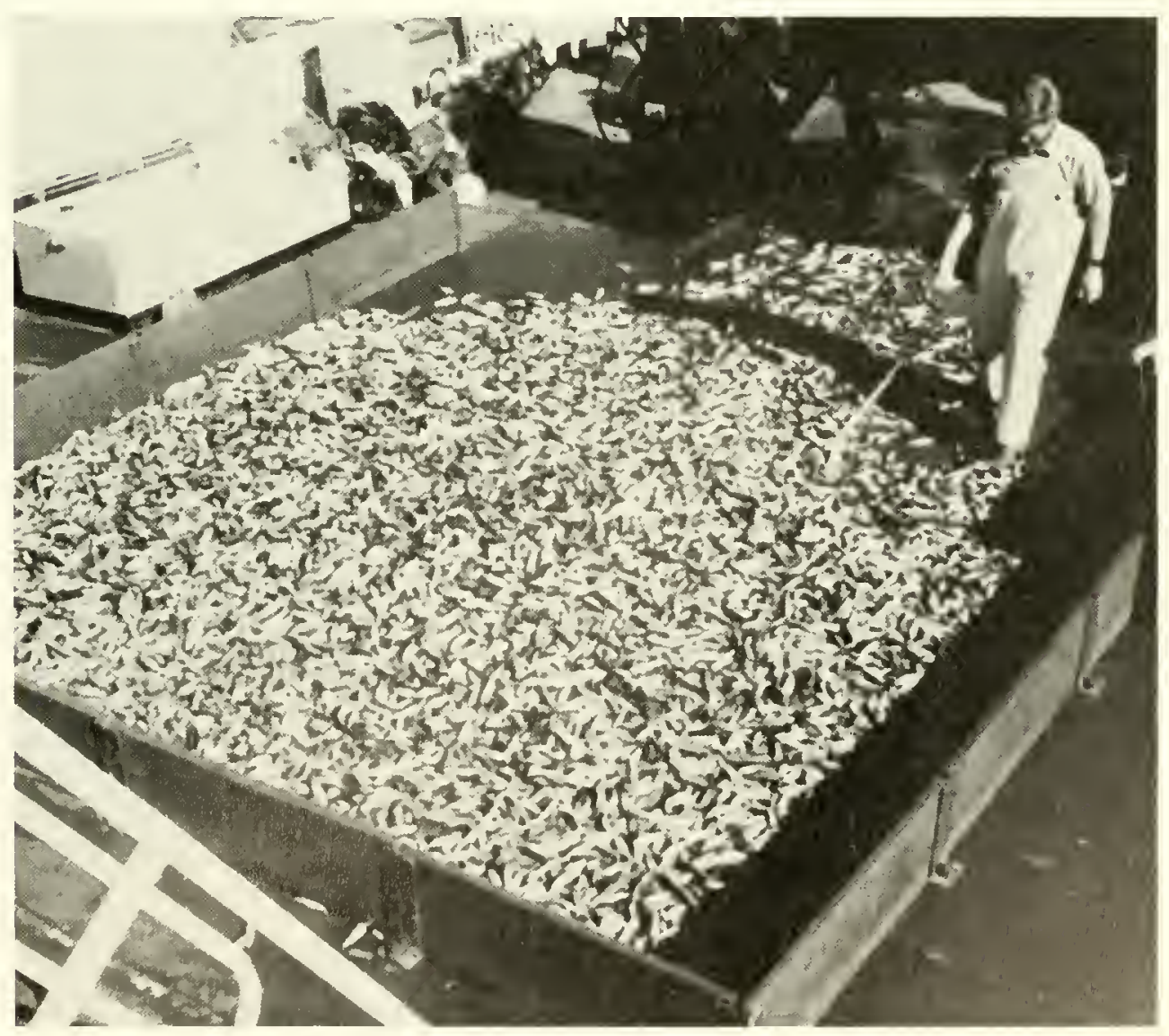




\section{... National Overview: Status and Potential of U.S. Living Marine Resources}

12

STATUS AND POTENTIAL OF ALASKA LMR'S

A large Pacific halibut is hauled in.
The Alaska fisheries have historically focused on salmon, halibut, and crab (Units 13, 19, and 20). With the displacement of foreign distant-water fleets by U.S. vessels, groundfish stocks of the eastern Bering Sea and Gulf of Alaska have become the basis for the largest domestic fish catch by volume and one of the world's largest single-species fisheries (walleye pollock). Conservatively estimated, Alaska's combined LTPY represents more than $41 \%$ of the national total. Twenty-five fisheries ( $74 \%$ of the regional total) are fully utilized; none is considered overutilized. The 1988 90 RAY has remained steady at 2.4 million $\mathrm{t}$, or $67 \%$ of the long-term regional yield, and is valued at more than $\$ 1.1$ billion.

With only one exception, the groundfish stocks off Alaska are well managed and in good-to-excellent condition. The CPY of 3.7 million $t$ is $13 \%$ above the LTPY estimate of 3.3 million $t$, owing in large measure to the current high abundance and above-average recruitment that have occurred in individual fisheries (principally certain Alaska salmon stocks, Pacific halibut, $\mathrm{Pa}$ cific cod, and most Bering Sea and Gulf of Alaska flatfish). Owing to the favorable biological health of the resources, the current yield from $21 \%$ of the stocks could be increased (i.e., they are listed as underutilized). This reflects, in part, the North Pa-

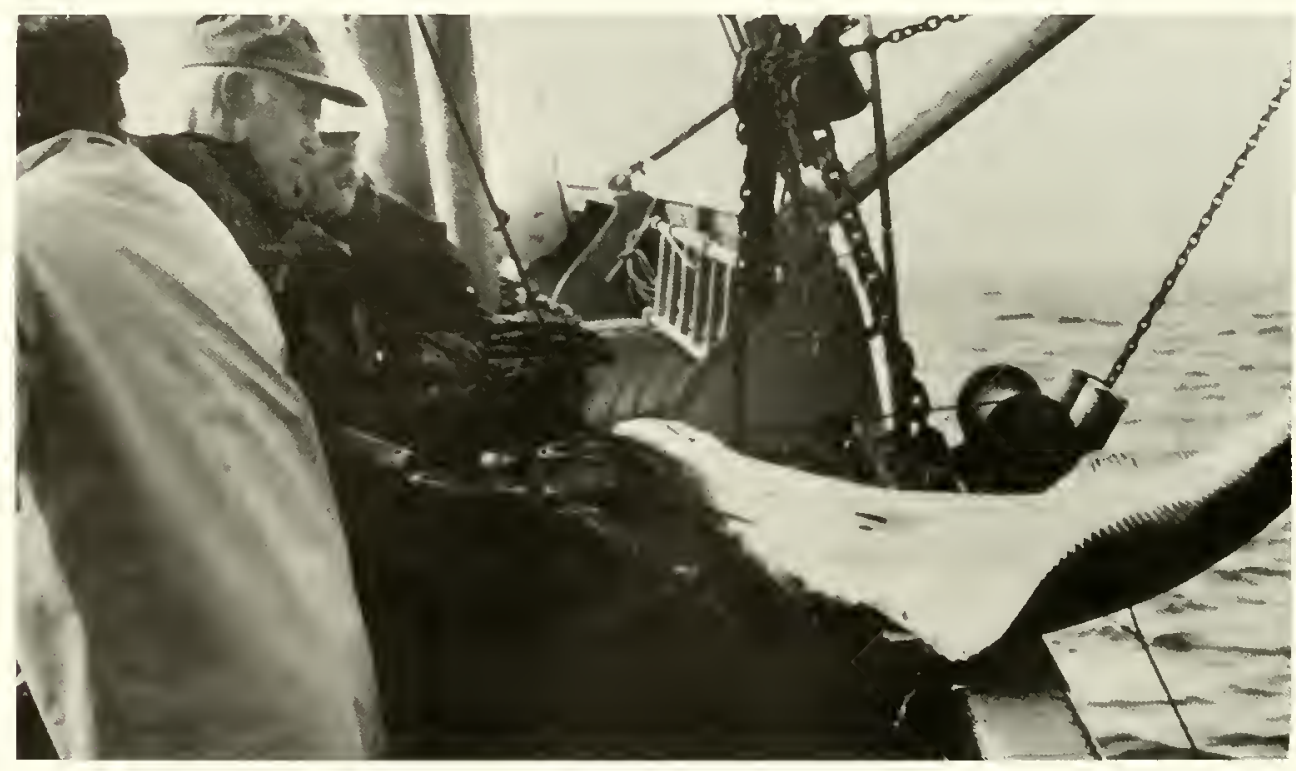

A big bag of walleye pollock taken in Alaska waters.

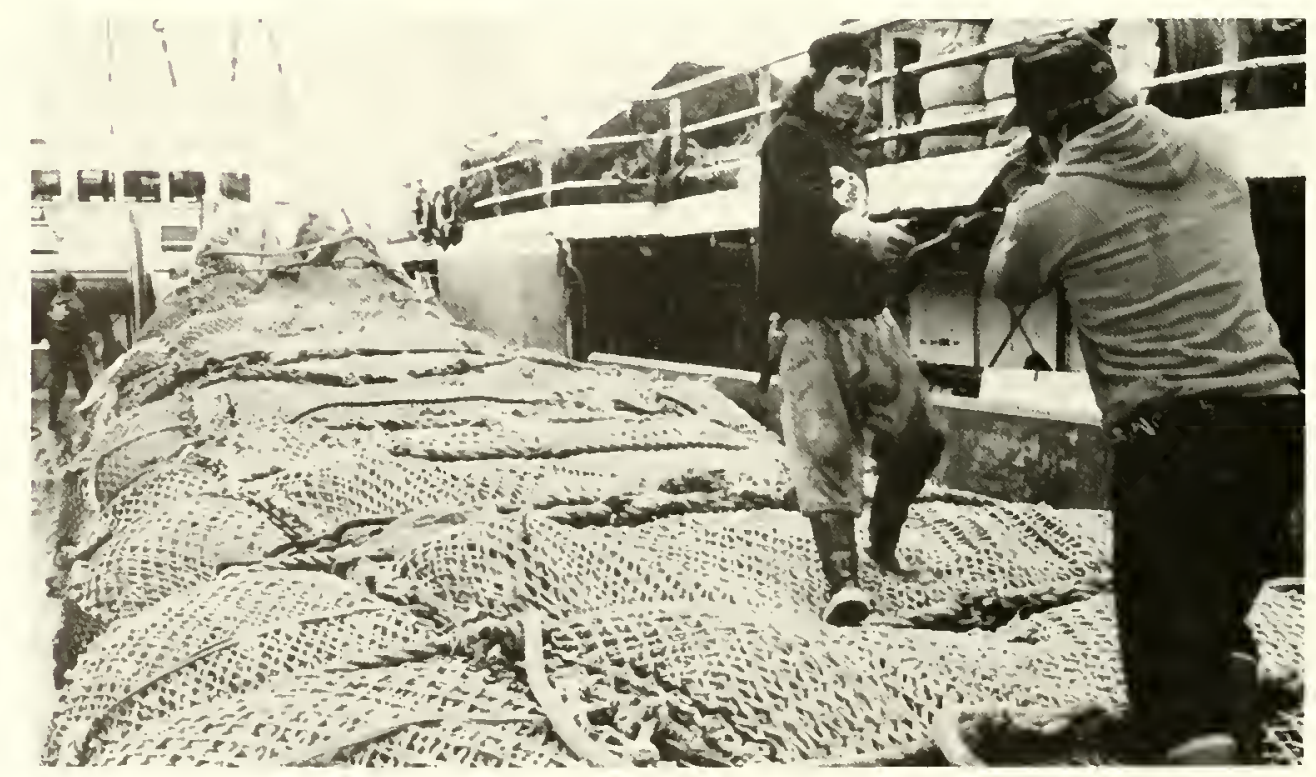


... ALASKA LMR'S

U.S. NEARSHORE LMR'S

A commercial digger on the Maine coast harvests soft-shelled clams and marine worms, the latter for bait. cific Fishery Management Council's annual cap on groundfish harvests at 2 million $t$ and bycatch restrictions for nontarget species. The cap provides a margin of safety for eastern Bering Sea groundfish to allow for uncertainty in biological assessments.

Alaska salmon stocks have rebounded to record high levels. Catches since 1980 have steadily increased to an all-time record of 155 million salmon landed in 1989. Pacific halibut stocks are in good condition, with CPY and RAY at $168 \%$ and $199 \%$, respectively, of the species' long-term yield. Both king and tanner crab have experienced wide recruitment swings and, having suffered severe population declines duning the early 1980 's, are slowly rebuilding.
It is difficult to assess the status of all nearshore species (Unit 21) around the entire U.S. coast because they come under varied management and data collection regimes. No realistic estimates exist for LTPY or CPY because of the diverse nature of these coastal and estuarine species and their fisheries. Management authority is usually a regional, state, and/or local responsibility, because most fisheries occur within the 3-mile interior boundary to the Federally controlled EEZ. But, generally, Atlantic oysters, hard and softshell clams, bay scallops, and abalones are overutilized, at least in part of their ranges. Fully utilized resources include Pacific shrimp and clams, Dungeness crab, blue crab, and calico scallop. The status of 20 of the 34 species included in this unit cannot be determined from the existing data. The latest RAY is conservatively set at 231,225 t. The commercial value of all nearshore resources is about $\$ 376$ million, which does not include the substantial recreational component.

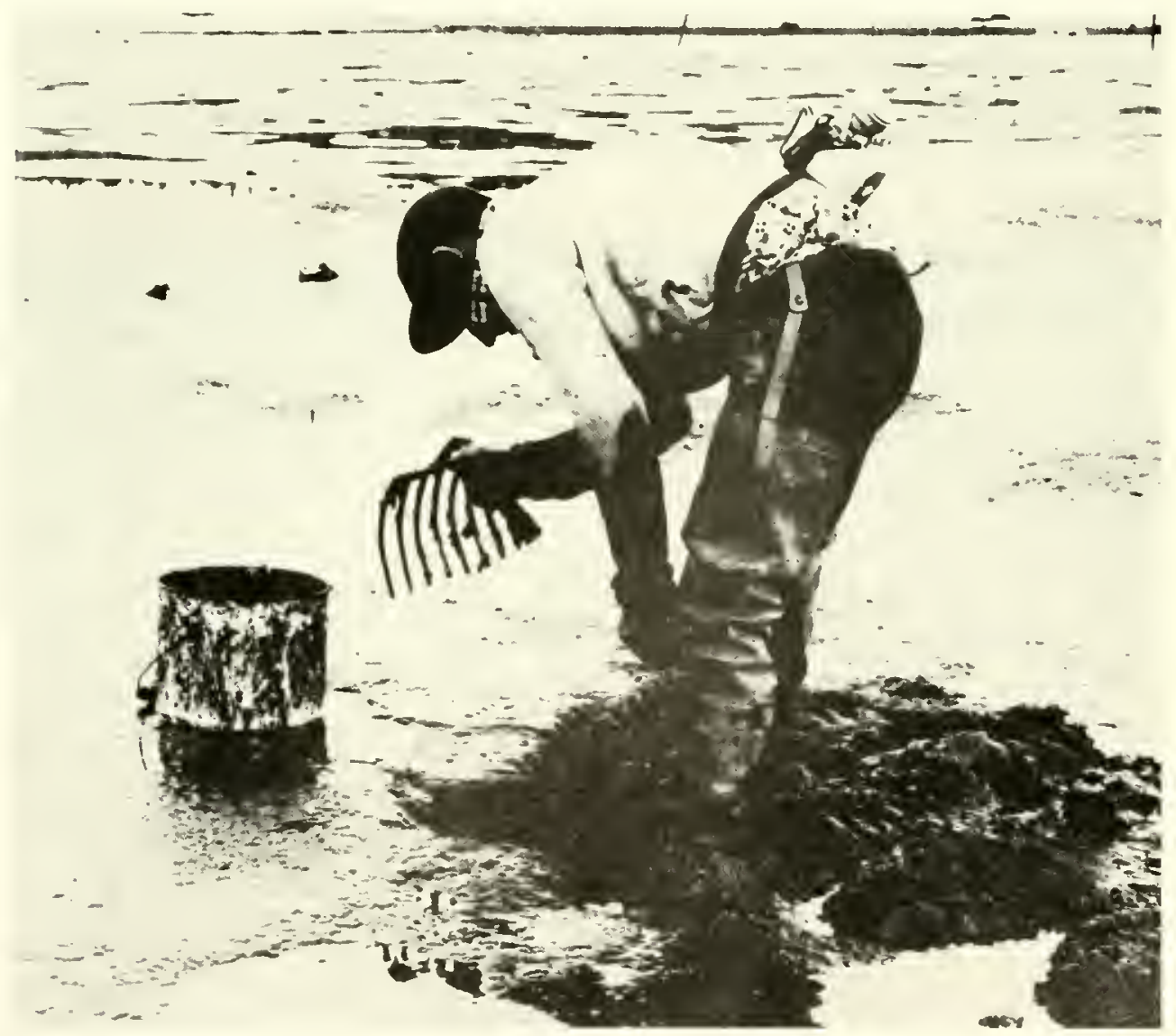




\section{... National Overview: Status and Potential of U.S. Living Marine Resources}

14

\section{MARINE MAMMALS AND SEA TURTLES}

The MMPA and ESA require regular status updates for marine mammal and sea turtle populations. The current state of our knowledge only allows 18 stocks to be assigned abundance trend estimates (Table 2). The rest are of unknown status (particularly the Pacific dolphin stocks).

\section{Marine Mammals}

Thirty-six species of marine mammals (Unit 22) range the western North Atlantic Ocean and the Gulf of Mexico, including 34 species of whales, dolphins, and porpoises, and two seal species. Abundance estimates are known for 9 species (Table 2). Of these, 3 found off the east coast are listed as endangered under ESA; of these, the Atlantic right whales are critically depleted and their long-term survival is in doubt. There is also serious concern about Mid-Atlantic coastal bottlenose dolphins and harbor porpoise. There are far too few data on other species, such as blue, fin, and pilot whales, to judge the current health of individual stocks.

Forty-two marine mammal species (Unit 23) occur in U.S. waters of the eastern North Pacific Ocean and eastern tropical Pacific, including 31 species of whales,
Table 2.-Status and trends of marine mammals and sea turtles.

\section{Unit and \\ Species}

22. Atlantic manine mammals

23. Pacific marine mammals

24. Sea turtles

Total

Percent of total

$22 \%$

$22 \%$

${ }^{\prime} \mathrm{E}=$ Endangered, $\mathrm{T}=$ Threatened, $\mathrm{D}=$ Depleted

California sea lions at rest in Elliott Bay, Seattle, Wash.

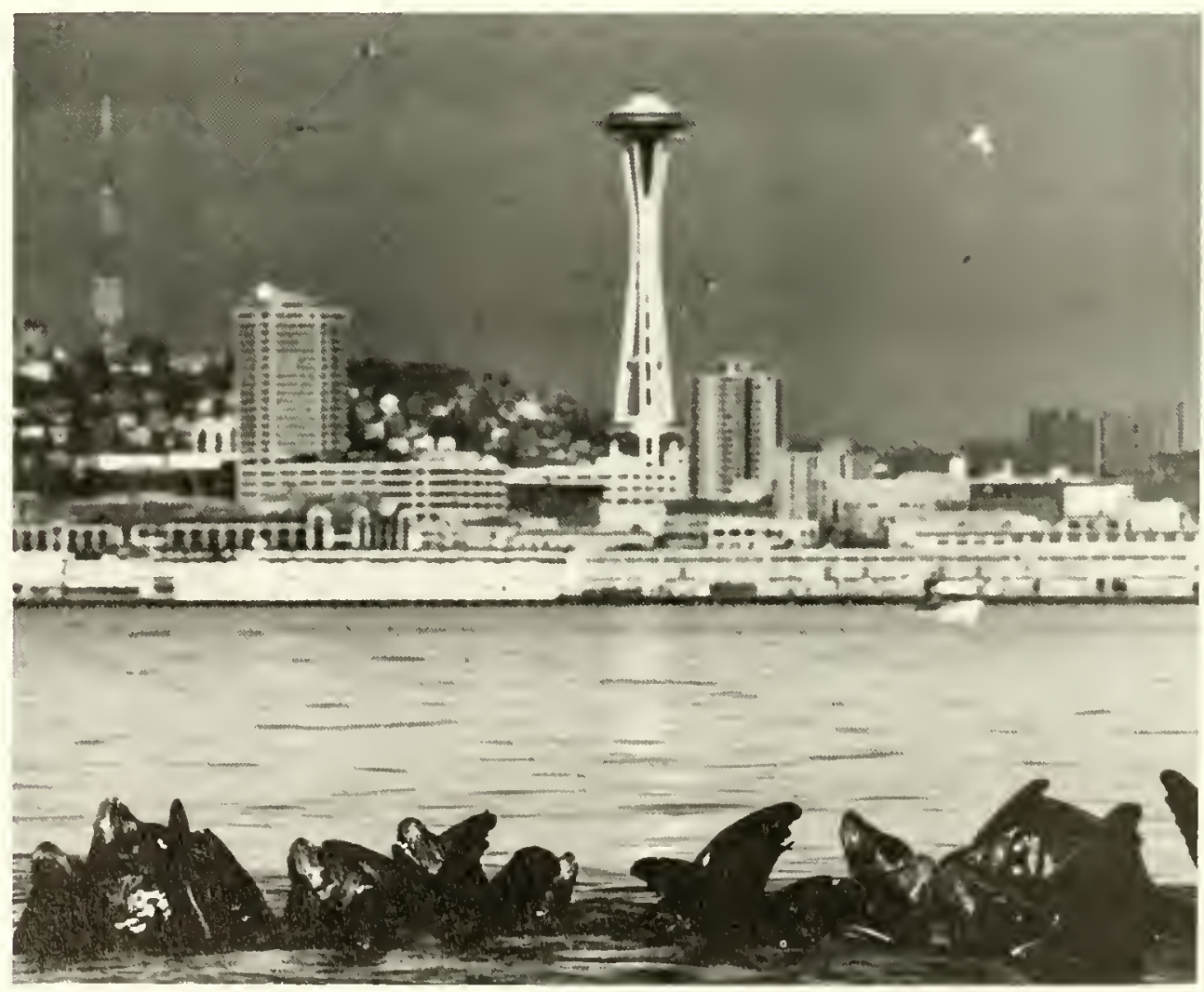


... Marine Mammals dolphins, and porpoises, and 11 species of seals and sea lions. Abundance estimates are known for 18 species (Table 2). Of these, 5 species are endangered or threatened under ESA guidelines. Although the data are incomplete, right whales in the eastern North Pacific are at critically low levels; only 5-7 sightings have been made in the past 25 years. The eastern North
Pacific or "California" stock of gray whales has recovered to or surpassed its historical abundance level. Moreover, south of Alaska some mammals have also recovered or are recovering to near historical abundance levels (i.e., harbor seal, California sea lion, northern fur seal, and the northern elephant seal).

\section{sea Turtles}

A green sea turtle comes ashore at French Frigate Shoals in the Hawaiian archipelago.
Six species of sea turtles (Unit 24) regularly spend all or part of their lives off the U.S. Atlantic and Pacific coasts, and in U.S. territorial waters of the Caribbean and western Pacific Ocean: The Kemp's ridley, olive ridley, loggerhead, green, hawksbill, and leatherback. Very few stock assessment data exist for any turtle species in U.S. waters.

Studies of nesting densities, however, provide a partial picture of population trends. The Kemp's ridley population has experienced a major decline since 1947 from an estimated 40,000 nesting females to less than 800 nests per year between 1978 and 1988. Loggerhead nesting populations have declined over the last 20-30 years on more northern U.S. beaches (e.g., Georgia and South Carolina). On the Atlan- tic beaches of south Florida, however, loggerheads have not shown a decline, and might even be increasing. Green turtle nestings on Florida beaches are low, but they increased between 1971 and 1989. Hawksbill turtles are too few in U.S. waters for a trend analysis. Leatherbacks nest on beaches of the Virgin Islands and Puerto Rico. Although nesting records are too few to detect trends, their numbers do not appear to be declining.

Kemp's ridleys, leatherbacks, and hawksbills are listed as endangered throughout their ranges; green turtles are endangered in Florida and threatened in all other locations; and loggerheads are listed as threatened throughout their range. Currently all five species are protected under the Endangered Species Act (Table 2).

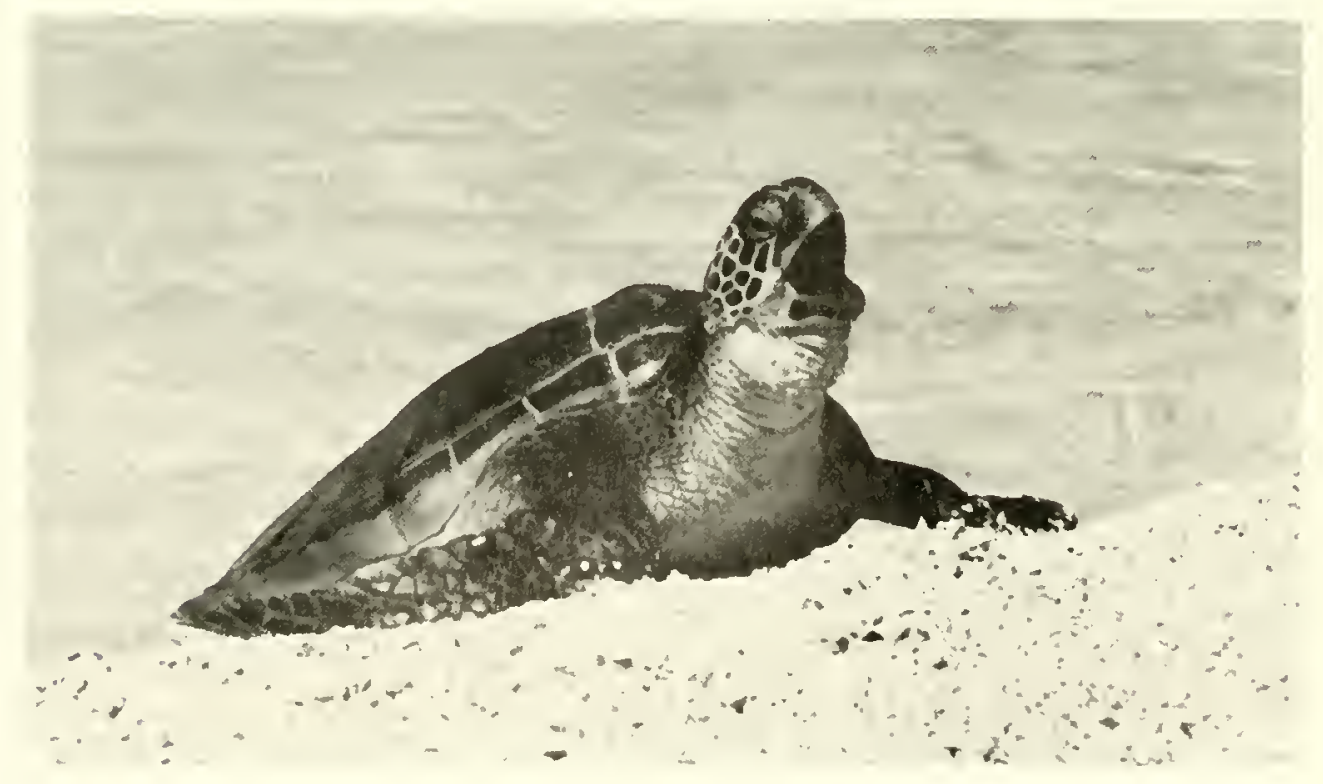


As noted in the Introduction, one purpose of this document is to serve as a report card on the Mation's stewardship of its living marine resources. Although this report does not assign a qualitative "grade," there are several areas where performance needs to improve.

\section{OVERUTILIZATION, EXCESS FISHING EFFORT, AND RESOURCE DEPLETION}

This document reports on 232 species or fishery resource groups (Table 3). Of the 153 species or species groups for which status has been assessed, 65 or $42 \%$ are overutilized. The list includes many of the Nation's most valuable fishery resources (e.g., most traditional New England groundfish and flounders, Atlantic salmon, sea scallops, Atlantic bluefin tuna, swordfish, large coastal pelagic sharks, Atlantic menhaden, spiny lobsters in the Southeast. Pacific ocean perch, blue marlin in the Pacific, albacore in the North Pacific, and nearshore oysters, hard clams, and abalones). The status of many populations of marine mammals and sea turtles is also of concern. Of the 37 stocks considered in this document, 13 are classified as endangered, 6 as threatened and 1 as depleted (Table 2). Current trends in abundance are known for only 15 stocks, and about half of them are declining.
For most overutilized resources, fishing effort is far in excess of what is needed to harvest the CPY or LTPY. Many resources are severely depleted as a result of excess fishing. As a result, the Nation is wasting large economic benefits and many recreational opportunities.

Still, the abundance of some fishery resources is high. In some cases, there is little economic demand for the resource (e.g., dogfish off the U.S. northeast coast and arrowtooth flounder in the North Pacific), but, in other cases where demand is great, a high biomass has been maintained by setting total allowable catches conservatively to reduce the risk of overharvesting the resource. There are also notable examples to be found in the marine mammal populations that have recovered under protection afforded to them by the MMPA (e.g., the eastern North Pacific gray whale and California sea lion).
Table 3.-Utilization of assessed stocks of U.S. living marine resources.

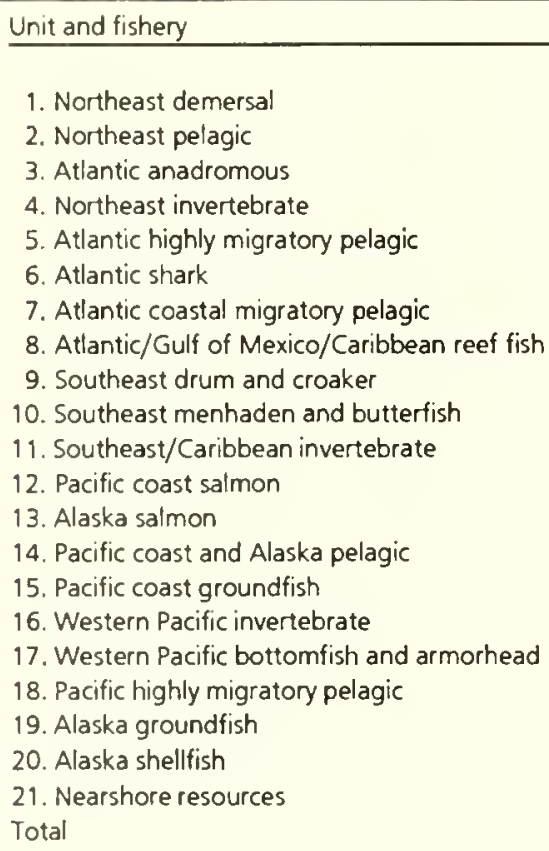

Unk

\begin{tabular}{rrrrr}
2 & 15 & 5 & 3 & 25 \\
3 & 1 & 2 & 4 & 6 \\
& 2 & 3 & & 5 \\
3 & 2 & 4 & 1 & 5 \\
1 & 1 & & 1 & 10 \\
3 & 3 & & 1 & 7 \\
17 & 10 & 1 & & 28 \\
4 & 3 & & & 7 \\
& 1 & 1 & 1 & 3 \\
5 & 8 & 1 & & 14 \\
& 5 & & & 5 \\
& & 5 & & 5 \\
& & 2 & 2 & 4 \\
7 & 2 & 7 & 2 & 18 \\
& & 1 & 1 & 2 \\
12 & 2 & & 4 & 6 \\
1 & & 1 & 3 & 18 \\
1 & & 2 & 1 & 23 \\
20 & 8 & 6 & & 34 \\
\hline 79 & 65 & 57 & 31 & 232 \\
& & & & $100 \%$
\end{tabular}


BYCATCH

\section{USER CONFLICTS}

Many, if not most, current fishing methods catch nontarget species or unmarketable sizes of marine life. This inadvertent or accidental catch is referred to as "bycatch." When the bycatch is used by the fishery without jeopardizing other more beneficial uses of the resource, it is not a concern. But bycatch is an increasing concern when it results in the following problems:

1) Discarding of large quantities of fish that are of low value because of their species or small size. This is particularly true when the small fish are a valuable species in their own right. For example, the discarded bycatch of finfish in the southeast Atlantic and Gulf of Mexico shrimp fisheries is believed to be several times larger than the shrimp catch, including billions of juveniles of valuable commercial and recreational species such as croaker, spot, and drum.

2) Discarding of economically valuable components of the catch to comply with regulations that are intended either to conserve the nontarget species or to reduce user-group conflicts (discussed below). For example, Bering Sea trawl fisheries for walleye pollock and yellowfin sole are not allowed to keep Pacific halibut, sablefish, salmon, and king and tanner crabs that are taken simultaneously with the targeted species. As a result, large quantities of valuable finfish and shellfish are wasted. To reduce discarding, it may also be necessary to limit the catch of target species below their potential yield.

3) Mortality to marine mammals and endangered species such as sea turtles. Seals and large and small cetaceans are taken as bycatch in many fisheries, including gillnet fisheries of New England, trawl fisheries for Atlantic mackerel, gillnet fisheries off the west coast and Alaska, and trawl fisheries off Alaska. Sea turtles are primarily taken as bycatch in southeast Atlantic and Gulf of Mexico shrimp fisheries, but the amount of turtle bycatch has been greatly reduced by regulations that require shrimpers to use turtle excluder devices (TED's) in their nets.

Another form of discarding (although it does not result from bycatch) that has raised some concern results from the practice of disposing of low value portions of animals and only retaining select body parts of greater value. Examples of this practice are "shark finning" in the Atlantic and roe fisheries on spawning walleye pollock in the Bering Sea and Gulf of Alaska.
Many competing special interest groups want to share in the benefits from living marine resources. This results in conflicts between components of the commercial fishing industry, such as inshore and offshore vessels off Alaska; between commercial and recreational fisheries, such as those in the southeast for Spanish and king mackerel; and between utilizing fisheries resources and ensuring total protection of marine mammals and endangered species.

In many cases, the resolution of these conflicts is controversial and may result in inefficiencies in fishing operations, discard ing, or the loss of opportunities to harvest part of the potential yield.

\section{INSUFFICIENT INFORMATION ON THE STATUS OF LIVING MARINE RESOURCES}

The status of utilization is unknown for $34 \%$ (Table 3 ) of the fish species or species groups considered in this document. The trend in abundance is unknown for $57 \%$ (Table 2) of the marine mammal and sea turtle species. Even for the species where status or the trend in abundance is known, the information is often imprecise. There are also large gaps in fundamental understanding of the LMR populations and of the ecosystems of which they are a part.

Many potential benefits from LMR's may not be achievable because of insufficient information. When the status of LMR's is unknown or imprecisely known, it is necessary to use them conservatively to guard against accidental depletion. The Gulf of Alaska pollock fishery is an example of this situation. Lack of precision in assessments of fishery resources often has been used to argue that the evidence of overutilization was not strong enough to justify restricting a fishery. This argument has led to the depletion of many stocks (e.g., most traditional New England groundfish and flounders). 


\section{... INSUFFICIENT INFORMATION ON THE STATUS OF LIVING MARINE RESOURCES}

Uncertainty about the relationship between marine marnmals and fisheries now threatens both. For example, it is possible that trawl fisheries in the Bering Sea are adversely affecting Steller sea lion populations, but there is little scientific basis for drawing a sound conclusion. The outcome of making management decisions without sufficient information could be that a valuable fishery is unnecessarily restricted to protect Steller sea lions or that the fishery unknowingly contributes to the demise of the Steller sea lion.

\section{ENVIRONMENTAL QUALITY}

Uitimately, the persistence of LMR populations depends on the "quality" of their environment. The effect of environmental quality on LMR's is most apparent for anadromous salmon stocks (both Atlantic and Pacific), many of which have been harmed by hydroelectric power development and other causes of habitat degradation, such as massive water diversions for agriculture and urban development. As a result, some west coast salmon stocks are in danger of extinction (e.g., Snake River sockeye and Sacramento River winter chinook).

Another apparent impact of environ- mental quality on fisheries is the widespread closure of inshore shellfish beds owing to contamination by pathogens and biotoxins (i.e., coliform bacteria and paralytic shellfish poisoning). For example, $83 \%$ of the shellfish production acreage in Massachusetts has been closed (Table 4).

The effects of environmental quality on other fishery resources is difficult to detect and quantify, but there are disturbing signs. For example, chemical contaminants in Boston Harbor and Puget Sound are the most probable causes of tumors in winter flounder and English sole, respectively.

\begin{tabular}{|c|c|c|c|c|}
\hline $\begin{array}{l}\text { Table 4.-Shellfish closures in } \\
\text { the Gulf of Maine. }\end{array}$ & Region & Year $^{1}$ & $\begin{array}{l}\text { Production } \\
\text { acreage }\end{array}$ & $\begin{array}{l}\text { Percent } \\
\text { restricted }\end{array}$ \\
\hline & Massachusetts & 1984 & 8,170 & 83 \\
\hline & New Hampshire & 1989 & 3.420 & 100 \\
\hline & Nova Scotia & 1985 & 26,671 & 15 \\
\hline & New Brunswick & 1985 & 9.702 & 32 \\
\hline
\end{tabular}

'Year of closure. 
NMFS has developed a "Strategic Plan for the Conservation and Wise Use of America's Living Marine Resource." It addresses the concerns discussed above. The plan is a fundamental departure from the approaches of the past. In particular, it calls for:

1) Risk-averse decisions in the face of uncertainty (i.e., erring on the side of conservation, not resource depletion);

2) Reduction of uncertainty by greatly expanding the scientific information base upon which decisions are based;

3) Controlled access to fisheries to reduce the tendency toward excess fishing capacity, economic waste, conflicts be- tween user groups, and industry pressure to make "risk-prone" decisions;

4) Development of more selective fishing practices to reduce bycatch; and

5) Implementation of a cohesive strategy, built on all applicable legislative authorities, to protect and restore the quality of the environments supporting LMR's.

For the plan to be successful, NMFS will need the cooperation of all those who use and benefit from the ocean's living marine resources. It will also need the support of all Americans concerned about the conservation and wise use of our common ocean heritage. 



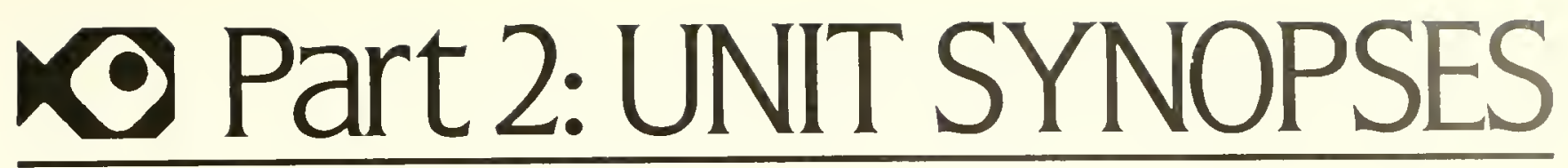





\section{INTRODUCTION}

The northeast U.S. demersal (groundfish) fisheries include about 35 fish species or stocks, primarily in New England waters, but also off the Mid-Atlantic states. In New England, the groundfish group is dominated by members of the cod and flounder families, dogfish sharks, and small skates. Mid-Atlantic groundfish fisheries land primarily summer flounder, scup, goosefish, and black sea bass.

Northeast groundfish fishermen use such fishing gears as otter trawls, gill nets, traps, and set lines. Otter trawling is the dominant fishing method throughout the region (1,104 vessels trawled in 1989, whereas 247 vessels fished with gill nets).
Many of the vessels switch gears seasonally. Total U.S. commercial landings of mixed groundfish in the northeast were $161,000 \mathrm{t}$ in 1990. Even if the sport catch $(12,000 \mathrm{t})$ and Canadian landings were included, the 1990 groundfish landings were still less than half (45\%) of their estimated long-term potential yield (LTPY) (Table 1-1). If the depleted northeast groundfish resources were restored, they alone would contribute another $\$ 180$ million annually to the region's economy and substantially boost recreational fisheries and their economic value.

Northeast groundfish are often found in mixed aggregations, are often caught in

\section{Table 1-1.-Recent average, current potential, and long-term potential yields in metric tons $(t)$, and status of utilization of northeast groundfish. The LTPY, CPY, and RAY for the unit equals the sum of the species' LTPY's, CPY's, and RAY's. Where the species' LTPY is unknown, the species' CPY is substituted in the sum. If the species' CPY is unknown, the species' RAY is substituted.}

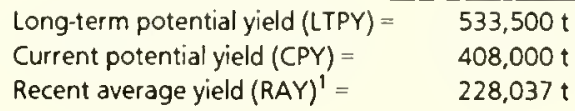

\begin{tabular}{lcccc}
\hline & & Yield $(t)$ & Status of \\
\cline { 2 - 3 } Species & RAYl & CPY & LTPY & utilization \\
\hline
\end{tabular}

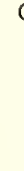

roundfish/flounders

Atlantic $\operatorname{cod}^{2.3}$

Pollock $2.3,4.5$

Silver hake

Summer flounder ${ }^{3}$

Winter flounder ${ }^{3}$

Yellowtail flounder

Haddock 2,6

American plaice

Witch flounder

Windowpane flounder

Red hake

Redfish

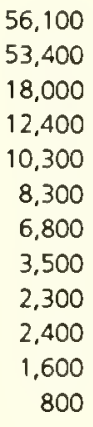

Skates/dogfish

Skates

Spiny dogfish

Other finfish

Goosefish

Scup ${ }^{3}$

White hake ${ }^{2}$

Weakfish $^{3}$

Black sea bass ${ }^{3}$

Cusk $^{2}$

Ocean pout

Spot ${ }^{3}$

Tilefish

Wolffish

Atlantic halibut

56,100
53.400
18,000
12,400
10,300
8,300
6,800
3,500
2,300
2,400
1,600
800

7,900
7,200

10,000
7,100
5,800
5,000
3,200
1,700
1,500
1,300
900
500
37

60,000

40,000

20,000

6,000

9.000

6,000

6,000

2,400

1,500

2,000

Unknown

600

25,000

200,000

$$
\begin{array}{r}
10,000 \\
6,700 \\
5,000
\end{array}
$$

Unknown

Unknown

1,200

1,300

Unknown

$$
900
$$$$
400
$$

Unknown

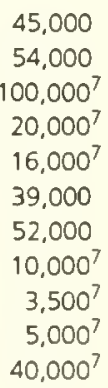

45,000

$00,000^{7}$

$20,000^{7}$

$16,000^{7}$

39,000

52.000

$0.000^{7}$

$5,000^{7}$

$40,000^{7}$

14,000

25,000

50,000

$10,000^{7}$
$12,500^{7}$

$5,000^{7}$

Unknown

Unknown

$1,500^{7}$

$12,500^{7}$

Unknown

Unknown

$700^{7}$

Unknown

\section{Over \\ Over \\ Fult \\ Over \\ Over \\ Over \\ Over \\ Over \\ Over \\ Full \\ Under \\ Over}

Under

Under

Over

Over

Full

Unknown

Full

Over

Full

Unknown

Over

Over

Over

\footnotetext{
$1988-90$ average

${ }^{2}$ Includes more than 1001 of foreign landings (primarly Canadian).

${ }^{3}$ Includes more than 1001 of recreational landings.

${ }^{4}$ For pollock, U 5 landings are only $11,700 \mathrm{t}(22 \%)$ of the RAY.

${ }^{5}$ Overutilized for U.S. portion of the stock, but not the Canadian portion

${ }^{6}$ For haddock, U.S landings are only 2,500 (37\%) of the RAY

'Provisional LTPY's, based on historical landings patterns
} 


\section{... INTRODUCTION}

\section{SPECIES AND STATUS}

\section{Principal Groundfish and Flounders}

the same nets, and are often composed of different mixes by area and time of year. Such interactions greatly complicate management. The complexity is reflected, for example, in the need for differing restrictions on mesh sizes, gear types, minimum fish sizes, and seasonal closures set by such groups as the New England and MidAtlantic Fishery Management Councils, Atlantic States Marine Fisheries Commission (ASMFC), state fishery agencies, and $\mathrm{Ca}$ nadian fishery management entities, because fish stocks often cross state and international boundaries. New England groundfish are managed primarily under the Northeast Multispecies Fisheries Management Plan (FMP) (13 species), as well as peripherally under provisions of the ASMFC Northern Shrimp Management Plan. Mid-Atlantic groundfish are managed under the Summer Flounder FMP. The region's demersal fisheries are thus managed indirectly regarding mesh sizes, minimum fish lengths, and some area closures. No direct U.S. controls on groundfish harvests (by catch quota, fishing effort, or fishing vessel numbers) now exist. Canada has established catch quotas and limited entry for fishing vessels for its portion of the transboundary fish stocks.
The principal groundfish and flounders group includes important cod family members (Atlantic cod, haddock, silver and red hake, pollock), flounders (yellowtail, summer, winter, witch, and windowpane flounders, and American plaice), and redfish (Fig. 1-1). Recent annual commercial landings of these 12 species have averaged $176,000 \mathrm{t}$, whereas their LTPY could be nearly 400,000 t (Table 1-1). Total value of the principal groundfish and flounder com mercial landings in 1990 was \$164 million. The northeast groundfish group also supports important recreational fisheries for summer and winter flounders, Atlantic cod, and other species. In 1990, recreational landings of principal groundfish and flounder species were 11,700 t. The estimated recreational fishing value of summer and winter flounders (the two most important of the principal groundfish and flounders) was $\$ 196$ million.

The abundance index for this group declined almost $70 \%$ between 1963 and 1974, reflecting the huge catch increases by foreign fleets (Fig. 1-1). Many stocks declined sharply in this group, notably Georges Bank haddock, most silver and red hake stocks, and most flounder stocks. By 1974, abundance levels for many
Figure 1-1.-U.S. commercial landings and abundance indices for principal groundfish and flounders off the New England coast, 1960-90. Abundance indices are mean weight $(\mathrm{kg})$ per tow taken in Northeast Fisheries science Center (NEFSC) autumn bottom trawl surveys. Species include: Atlantic cod, haddock, pollock, redfish, silver, red, and white hakes, American plaice, and the yellowtail, winter, windowpane, witch, and summer flounders.

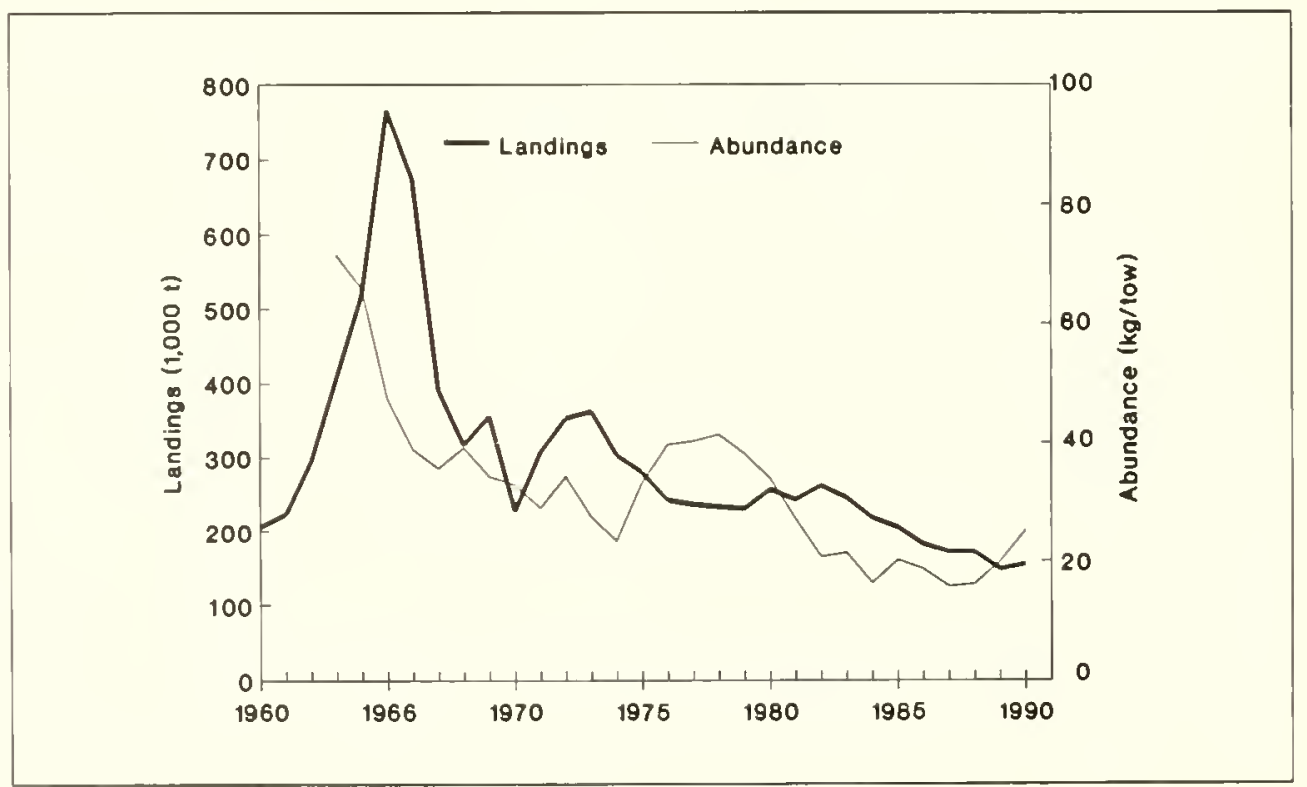


... Principal Groundfish and Flounders stocks were the lowest ever recorded.

Groundfish partly recovered during the late 1970's because overall fishing efforts were reduced by restrictive management under the International Commission for the Northwest Atlantic Fisheries (ICNAF) and by the advent of the Magnuson Fishery Conservation and Management Act (MFCMA) in 1976. Cod and haddock numbers increased markedly; pollock and several flounder stocks also grew. Overall, the groundfish stock index peaked in 1978, then began to decline again and fell in 1987 and 1988 to extremely low values. The 1989 and 1990 index values were slightly higher than the previous two years, primarily owing to recruitment of moderate 1987 year classes of Atlantic cod and yellowtail flounder.

Domestic fishing for northeast demersal fishes increased rapidly after the MFCMA took effect in 1977 and more than doubled during the first 10 years. Effort has remained at near-peak levels, despite large declines in overall catch.

\section{skates and Dogfish sharks}

Figure 1-2.-U.S. commercial landings and abundance indices for skates and dogfish off the northeastern U.S. Coast, 1960-90. Abundance indices are mean weight ( $k g$ ) per tow taken in NEFSC spring bottom trawl surveys. Species include little, winter, barndoor, brier, thorny, leopard, and smooth-tailed skates, and spiny and smooth dogfish.
Dogfish and skates are a significant and growing part of overall northeast groundfish stocks (Fig. 1-2). Of the two dogfishes (spiny and smooth), the spiny dogfish is dominant by far. Seven species of skates (little, winter, barndoor, brier, thorny, leopard, and smooth-tailed) occur on the northeast shelf, but three (winter, little, and thorny skates) produce most of the landings.

Skate and spiny dogfish landings have increased in recent years (spiny dogfish landings in 1990 were $14,300 \mathrm{t}$, up from $4,500 \mathrm{t}$ in 1989; total skate landings were
$11,300 \mathrm{t}$ in 1990, up from 6,600 $\mathrm{t}$ in 1989). Nevertheless, these landings levels remain well below the long-term potential landings and the current potential yields for these fish. This is due to a steady increase in the stocks throughout the 1970's and 1980's (Fig. 1-2). Survey catches of both dogfish and skates since 1986 have been the highest observed. These dogfish and skate increases, coupled with groundfish and flounder declines, indicate that the proportion of dogfish and skates in the Georges Bank surveys has risen from roughly $25 \%$ in 1963 to nearly $75 \%$ in recent years.

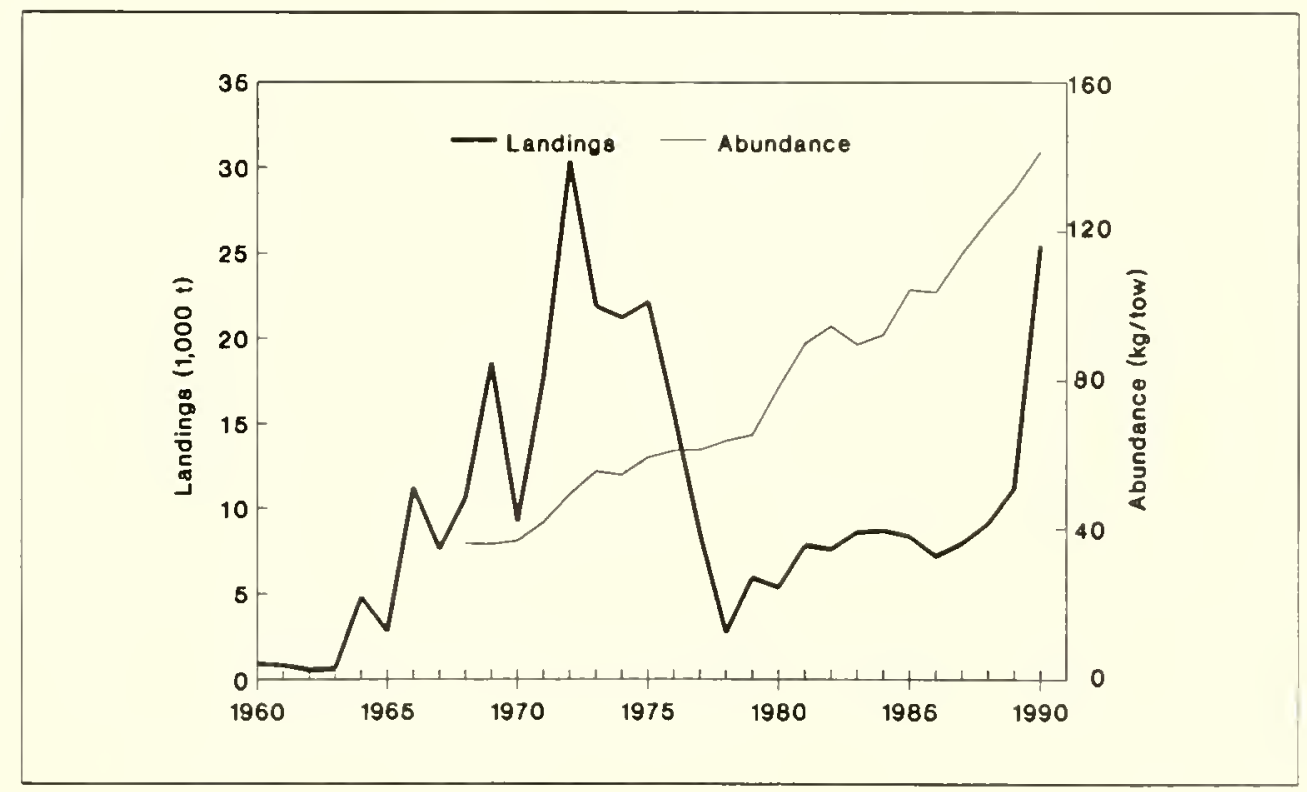




\section{other Finfish}

Other groundfish taken primarily as bycatch in the Gulf of Maine are goosefish, cusk, wolffish, and Atlantic halibut. Ocean pout is a bycatch in southern New England, while Mid-Atlantic bycatch species are scup, weakfish, black sea bass, spot, tilefish, searobin, and others. As a group, these species are generally overutilized; current landings are generally well below long-term maxima (Table 1-1). Most of these stocks are managed incidentally under FMP's for primary groundfish species. For example, goosefish, cusk, wolffish, and halibut (all of which are overutilized) are taken in various groundfish fisheries that are regulated under the Northeast Multispecies FMP. Similarly, scup and black sea bass are major components of the summer flounder fishery. The ASMFC has developed a weakfish FMP, and several other stocks (tilefish, scup, and black sea bass) are slated for future FMP's.

ISSUES
Principal Groundfish
and Flounder

Skate and Dogfish
Overutilization and depletion of spawning stocks are primary concerns for northeast groundfish. Fishing regulations apply only indirect controls (e.g., via mesh size, minimum fish size, and/or area closures) on harvests. Other important issues are the bycatch of small groundfish in certain trawl fisheries and the incompatibility of mesh and fish size regulations which results in excessive groundfish discards. Many New England groundfishes (particularly on Georges Bank) cross the U.S.-Canada boundary, but ineffective bilateral accords have contributed to the depletion of these stocks. So far, the northeast groundfishes have not been seriously hurt by coastal pollution, although species such as winter flounder are at risk. Also, there is concern that certain shelf-water warming scenarios could alter fish distribution patterns and predator-prey interactions. Important marine mammal-fishery interactions also need to be understood better.
The current high numbers of skates and dogfish make them a dominant part of the mixed groundfish catches, but because there is little market for them, many are discarded. In addition, the recovery of de- pleted groundfish may be inhibited by the great numbers of dogfish and skates that compete for the same food items or that may prey on young groundfish. 
INTRODUCTION

\section{SPECIES AND STATUS}

Figure 2-1.-U.S. commercial landings and abundance indices for Atlantic herring and Atlantic mackerel off the northeastern U.S. coast, 1960-90. Abundance indices are mean weight ( $\mathrm{kg}$ ) per tow taken in NEFSC spring bottom trawl surveys. Landings data are for the Georges Bank and Gulf of Maine herring stocks and for the coastwide Atlantic mackerel stock throughout jts range.
Commercial landings of pelagic or midwater fishes off the U.S. northeast coast have averaged about $180,000 \mathrm{t}$ since 1988 , while recreational landings (primarily bluefish and mackerel) have been about $23,000 \mathrm{t}$. In 1990, the commercial landings produced about $\$ 36$ million in commercial dockside revenue, of which the long-finned squid accounted for the greatest portion (\$14 million). Bluefish and mackerel angling is important to the region, and an estimated \$345 million is spent annually by bluefish anglers.
The U.S. northeast midwater fisheries are dominated by six species: Atlantic mackerel, Atlantic herring, butterfish, bluefish, and the long-finned and short-finned squids. Four are considered underutilized: Mackerel, butterfish, and the two squids.

The long-term population trends for herring and mackerel, the principal pelagic species, have fluctuated considerably during the last 25 years (Fig. 2-1). The abundance index reached minimal levels in the mid-1970's, reflecting pronounced declines for both species (as well as the collapse of the Georges Bank herring). Both species have been increasing in recent years. Atlantic mackerel recovered during the 1980's, and stock assessments indicate a total stock of about 2.5 million $t$. Mackerel landings in 1990 were very lowonly $60,600 \mathrm{t}$. Clearly, large quantities of mackerel are unused (Table 2-1), though some uncertainty in assessments remain.
Growth, maturity rates, and productivity declined as the stock has grown.

The Gulf of Maine herring stock is considered fully utilized, and total 1990 landings were $51,300 \mathrm{t}$, representing a $125 \%$ increase over the 1983 level. The Georges Bank herring was virtually wiped out, after landings of over $370,000 \mathrm{t}$ in 1967 and subsequent excessive catches. There are indications now of a recovery of the Georges Bank herrings, based on U.S. and Canadian studies.

Of the two squids, the long-finned squid is the more important, owing to strong international export markets (primarily Italy and Spain). Nevertheless, both species are considered underfished. Surveys indicate their numbers are above average and landings are well below top historical levels. Seasonal changes affect the availability of both species to fishermen, especially the short-finned squid.

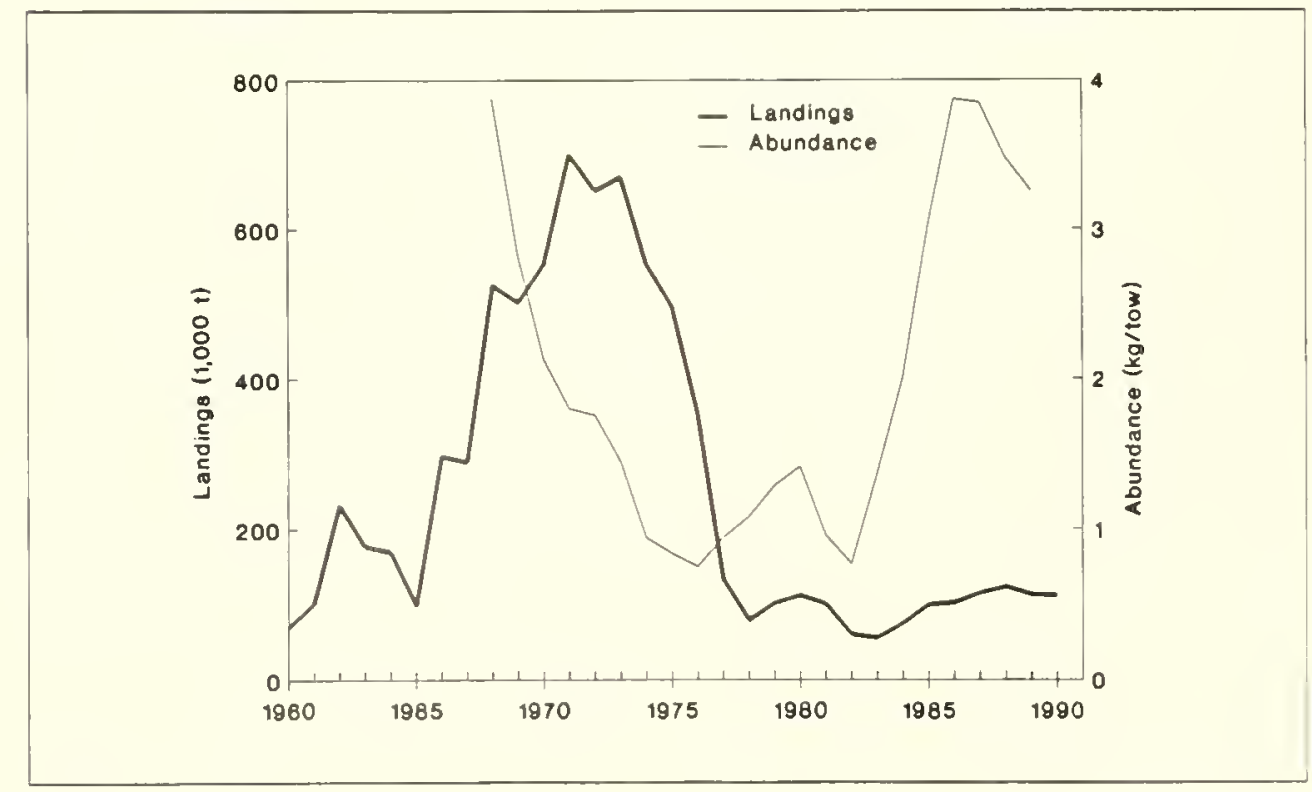




\section{... Northeast Pelagic Fisheries}

... SPECIES AND STATUS

Table 2-1.-Recent average, current potential, and long-term potential yields in metric tons $(t)$, and status of utilization of northeast U.S. pelagic fisheries. The LTPY, CPY, and RAY for the unit equals the sum of the species' LTPY'S, CPY's, and RAY's.
Butterfish are likewise considered underutilized, though landings have dropped considerably in recent years, owing mostly to poor foreign markets. The butterfish fishery is currently well below its LTPY (Table 2-1).

Bluefish landings peaked in 1980 at
$72,600 \mathrm{t}$ but declined to a 30,800 t average in recent years (Table 2-1). Most bluefish (over $80 \%$ ) are caught by sport fishermen. Recent catch declines and a drop in the species' abundance index suggest that bluefish decreased during the 1980's and that the stock is fully exploited. $\begin{array}{ll}\text { Long-term potential yield (LTPY) }= & 470,000 \mathrm{t} \\ \text { Current potential yield (CPY) }= & 571,000 \mathrm{t} \\ \text { Recent average yield }(\text { RAY })^{\prime}= & 176,700 \mathrm{t}\end{array}$

\begin{tabular}{|c|c|c|c|c|}
\hline \multirow[b]{2}{*}{ Species } & \multicolumn{3}{|c|}{ Yield $(t)$} & \multirow{2}{*}{$\begin{array}{l}\text { Status of } \\
\text { utilization }\end{array}$} \\
\hline & RAY' & CPY & LTPY & \\
\hline Atlantic mackerel $2,3,4$ & 73.100 & 400,000 & 200,000 & Under \\
\hline Atlantic herring & 44,300 & 51,000 & $20,000^{5}$ & Full \\
\hline Bluefish ${ }^{3}$ & 30,800 & 30,000 & $60,000^{5}$ & Full \\
\hline \multicolumn{5}{|l|}{ Squids } \\
\hline Long-finned & 19.200 & 44,000 & 44,000 & Under \\
\hline Short-finned & 6,800 & 30,000 & 30,000 & Under \\
\hline Butterfish & 2,500 & 16,000 & 16,000 & Under \\
\hline
\end{tabular}

'1988-90 average (including foreign and recreatıonal calches).

${ }^{2}$ Includes more than $100 \mathrm{l}$ of forergn landings (primarily Canadian).

${ }^{3}$ Includes more than 100 i of recreational landings.

${ }^{4}$ For mackerel. U.S landings are only $16.100 \mathrm{i}(22 \%)$ of the RAY

${ }^{5}$ Provisional LTPY's, based on historical landings patterns.

\section{ISSUES}

For mackerel, butterfish, and the squids, the recent average yields represent only about $30 \%$ of the LTPY's and, given the current high abundance of mackerel, only about $20 \%$ of the CPY.

Biological interactions of all these stocks have a significant effect on their productivity. Herring, mackerel, and the squids are primary diet items for many predatory fishes, seabirds, and marine mammals. Thus, development of more extensive fisheries will entail some bycatch of marine mammals, primarily pilot whales and common dolphins. Similarly, development of significant fisheries for the herring, mackerel, and squids may affect species like cod, hakes, pollock, goosefish, and spiny dogfish which use them for food. On the other hand, these pelagic species are also predators of young fish of many species.

Uncertainty in the identification of mackerel, herring, and squid stocks is another problem for fishery managers. For example, two mackerel spawning stocks have been identified, but whether or how much either has increased is not known. Likewise, lack of information on the stock structure of both squid species adds uncertainty to production data and stock relationships.

The bottom trawl surveys reflect stock biomass trends generally, but they are not very precise owing to strong effects of the environment on the distribution of the species. Increasing assessment precision of small pelagic stocks will require the development of new survey series, perhaps including midwater trawling combined with advanced hydroacoustic sampling. 


\section{INTRODUCTION}

The anadromous species of the Atlantic seaboard are a diverse group, including river herrings (alewife, blueback herring, hickory shad). American shad, striped bass, Atlantic salmon, sturgeons (Atlantic and shortnose), and rainbow smelt. Regulation of their stocks is likewise diverse: The Atlantic States Marine Fisheries Commission (ASMFC) has implemented a Fishery Management Plan (FMP) for river herrings and American shad, while shortnose sturgeon is managed under an Endangered Species Act (ESA) recovery plan. Atlantic salmon are regulated by a
New England Council FMP and are also under North Atlantic Salmon Conservation Organization (NASCO) auspices. Striped bass are regulated under an ASMFC FMP and by special Federal authority under the Atlantic Striped Bass Act (implemented by NMFS and USFWS). Current commercial landings of Atlantic anadromous species (Table 3-1; Fig. 3-1, 3-2) are only about 4,000 t, far below historic levels. Several are or were of major recreational importance to the region (including American shad, striped bass, and Atlantic salmon).

\begin{abstract}
Table 3-1.-Recent average, current potential, and long-term potential yields in metric tons (t), and status of utilization of Atlantic anadromous fisheries. The LTPY, CPY, and RAY for the unit equals the sum of the species' LTPY's, CPY's, and RAY's. Where the species' LTPY is unknown, the species' CPY is substituted in the sum. If the species' CPY is unknown, the species' RAY is substituted.
\end{abstract}

$\begin{array}{ll}\text { Long-term potential yield (LTPY) }= & 3,954 \mathrm{t} \\ \text { Current potential yield }(\text { CPY })= & 3,954 \mathrm{t} \\ \text { Recent average yield }(\text { RAY })^{1}= & 3,954 \mathrm{t}\end{array}$

\begin{tabular}{|c|c|c|c|c|}
\hline \multirow[b]{2}{*}{ Species } & \multicolumn{3}{|c|}{ Yield $(t)$} & \multirow{2}{*}{$\begin{array}{l}\text { Status of } \\
\text { utilization }\end{array}$} \\
\hline & RAY ${ }^{\prime}$ & CPY & LTPY & \\
\hline Alewife & 1,800 & Unknown & Unknown & Variable by river \\
\hline American shad & 1,200 & Unknown & Unknown & Variable by river \\
\hline Striped bass ${ }^{2}$ & 900 & Unknown & Unknown & Full \\
\hline Sturgeons & 54 & Unknown & Unknown & Variable by river \\
\hline Atlantic salmon & $(5,000)^{3}$ & $500^{4}$ & Unknown & Over \\
\hline
\end{tabular}

'1988-90 average, including foreign and recreational calches

${ }^{2}$ Includes significant recreational landings

${ }^{3}$ Allantic salmon RAY in numbers of fish, primarily intercepted in distanl-water commercial fisheries.

${ }^{4}$ Atlantic saimon CPY in numbers for U.S waters only
SPECIES AND STATUS
Atlantic salmon historically spawned in many large New England river systems, but dams, pollution, and industrial and agricultural development combined to eliminate most native runs long ago. Today, the only self-supporting U.S. salmon runs are in Maine. Restoration efforts, in the form of stocking and fish passage construction, are underway in the Connecticut, Pawcatuck, Merrimack, and Penobscot Rivers. After 2-3 years of river life, U.S. Atlantic salmon migrate to sea and through Canadian and Greenland waters.

Atlantic salmon spawning-run sizes in Maine rivers, plus estimated U.S. and distant-water catches, are listed in Figure 3-1. U.S. angler harvests averaged 430 fish in Maine rivers in recent years, about $10 \%$ of the runs. Foreign distant-water catches
(Canadian and Greenland high-seas commercial gill netting) of (I.S. salmon are estimated at $60-80 \%$ of the run. Those salmon fisheries are regulated by NASCO.

Three main striped bass stocks range along the Atlantic coast: Hudson River, Chesapeake Bay, and Roanoke River (N.C.). Historically, striped bass have supported important commercial and sport fisheries, and recreational catches have often equaled or exceeded commercial landings (Fig. 3-2). Commercial fishermen use a variety of gears, including haul seines, trawls, pound and gill nets, and hook-and-line. Commercial landings peaked in 1973, and then began a precipitous decline. The declining landings, coupled with consistently poor recruitment in the Chesapeake Bay, spurred restrictive regulations by the ASMFC in the mid- 


\section{... Atlantic Anadromous Fisheries}

... SPECIES AND STATUS

Figure 3-1.-Estimated sizes of spawning runs of Atlantic salmon to Maine rivers (numbers of fish) and the total catch by U.S. anglers and foreign commercial fishermen of fish from those rivers, 1967-90. The foreign salmon catch is estimated from data on tagged and recaptured salmon. 1980's. Additionally, the U.S. Congress passed the Striped Bass Conservation Act which empowered the Departments of Commerce and Interior to bar striped bass fishing in any state which ASMFC found not in compliance with its FMP.

In 1989, high recruitment in the Chesapeake Bay (Fig. 3-2) triggered a slight relaxation of regulations and allowed increased fishing on all Atlantic striped bass stocks in 1990 . The fisheries remain closely monitored and rigidly controlled. Modeling studies indicate that stocks should continue to recover if fishing annually removes $22 \%$ or less of the legal-sized fish.

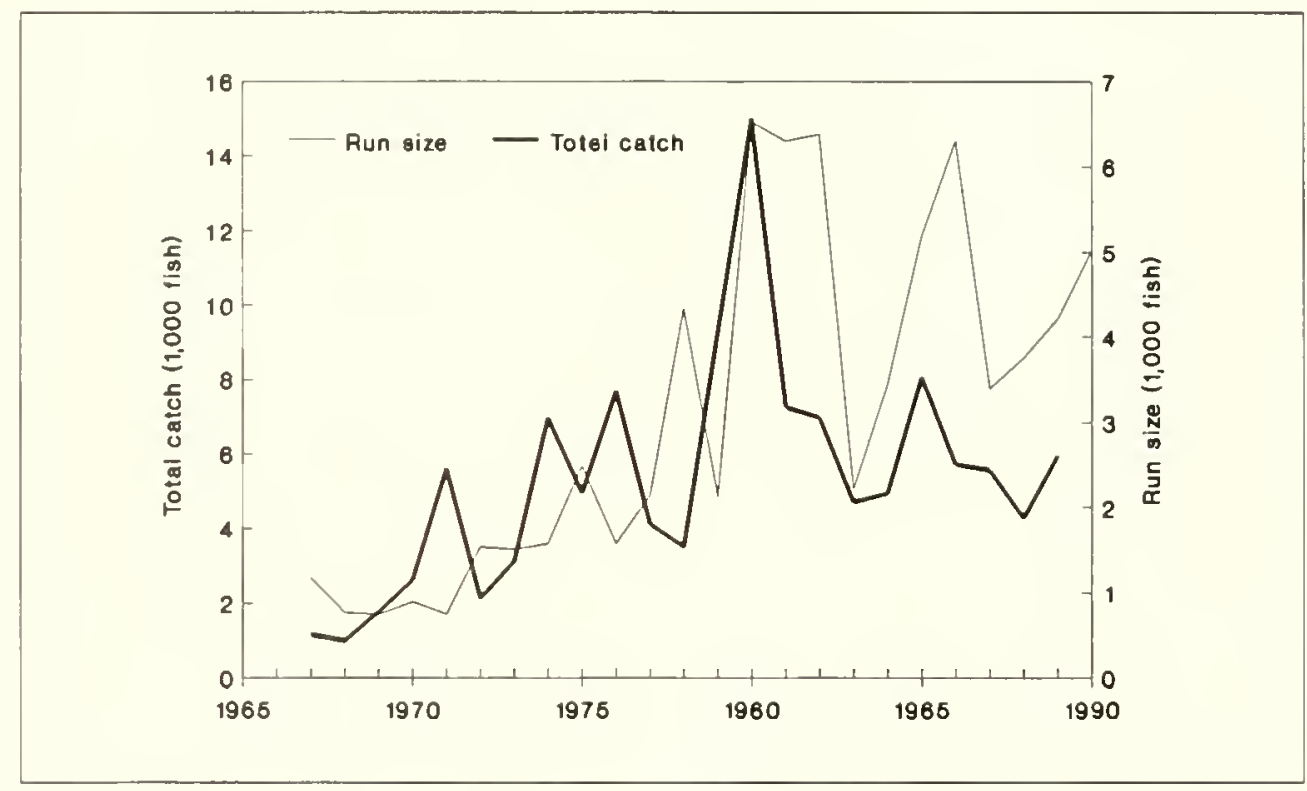

Figure 3-2.--Striped bass catches in commercial and recreational fisheries, and the recruitment index (Maryland "seine index") of young striped bass abundance in the Chesapeake Bay, 1954-90. The recruitment index is the average catch per seine haul. 
ISSUES

Losses of Atlantic salmon of U.S. origin in commercial fisheries off Canada and West Greenland severely restrict the restoration of U.S. runs and fisheries. Currently, these catches are about 10 times the home-water catch of U.S. anglers. Problems with the downstream passage of young salmon and the upstream passage of adults around dams also hamper wild salmon restoration in many rivers. Additionally, the habitat in many former salmon streams is too degraded now to produce salmon. Long-term climate change may also affect Atlantic salmon. Warmer average temperatures may allow wider foraging in West Greenland waters by U.S. salmon, but may change the timing of migrations from river to ocean waters.

A particular concern for striped bass is the potential impact of catch-and-release fishing. Striped bass angling effort currently far exceeds commercial fishing effort, and during the late 1980 's over $90 \%$ of the recreational catch was released alive. If survival rates of the released fish are low, then hooking mortality may seriously compromise any benefit of high minimum sizes. Chesapeake Bay water quality is another concern. Fishing restrictions have helped rebuild the Bay's severely depleted spawning stocks. However, if poor water quality hampers or prohibits survival of young bass, striped bass restoration will remain threatened. 


\section{INTRODUCTION}

Several invertebrate species (i.e., lobsters, mollusks, and shrimps) have long sustained the region's most valuable fisheries. Some of them are quite sensitive to oceanic temperature changes, and popula- tions and catches have fluctuated accordingly. While squids are also invertebrates, they are covered in Unit 2 with other "pelagic" fishes.

\section{SPECIES AND STATUS}

The region's major invertebrate fisheries target five species: American lobster, surf clam, ocean quahog, sea scallop, and northern shrimp (Table 4-1). In 1990 the total value of these five species was $\$ 359$ million. Lobster (\$154 million) and sea scallop ( $\$ 148$ million) were the most valuable of all northeast fisheries landings. Together, these five species are valued highest of all northeast commercial fisheries.
Table 4-1.-Average annual, current potential, and long-term potential yields in metric tons $(t)$, and status of utilization of northeast invertebrate fisheries. The LTPY, CPY, and RAY for the unit equals the sum of the species' LTPY'S, CPY's, and RAY'S. Where the species' LTPY is unknown, the species' CPY is substituted in the sum.

$\begin{array}{lr}\text { Long-term potential yield (LTPY) }= & 67,700 \mathrm{t} \\ \text { Current potential yield }(\text { CPY })= & 104,700 \mathrm{t} \\ \text { Recent average yield }(\text { RAY })^{?}= & 95,300 \mathrm{t}\end{array}$

\begin{tabular}{|c|c|c|c|c|}
\hline \multirow[b]{2}{*}{ Species } & \multicolumn{3}{|c|}{ Yield (t) } & \multirow{2}{*}{$\begin{array}{l}\text { Status of } \\
\text { utilization }\end{array}$} \\
\hline & RAY $^{1}$ & $\mathrm{CPY}$ & LTPY & \\
\hline Surf clam² & 30,600 & 32,600 & Unknown & Full \\
\hline American lobster & 24,600 & 27.600 & Unknown & Over \\
\hline Ocean quahog ${ }^{2}$ & 21,800 & 22,700 & 22,700 & Full \\
\hline Sea scallop 2 & 15,100 & 17,400 & 13,300 & Over \\
\hline Northern shrimp & 3,200 & 4,400 & $4,000^{3}$ & Full \\
\hline
\end{tabular}

${ }^{1} 1988-90$ average.

${ }^{2}$ Data for bivalve species are in shucked meat weights.

${ }^{3}$ Provisional LTPY, based on historical landings patterns.

\section{American Lobster}

Surf Clam and ocean Quahog
American lobsters are caught primarily with baited traps; only a small fraction of U.S. landings come from trawling. Lobsters are partially regulated under a Northeast Fisheries Management Council (NEFMC) Fishery Management Plan (FMP). Because most lobsters are caught within state waters, state catch rules usually apply. American lobsters are regulated primarily by a minimum carapace length of $39 / 32$-inch ( 83 $\mathrm{mm}$ ) in the EEZ and $31 / 4-i$ ch in most state waters. Fishing mortality rates for both inshore and offshore populations far exceed the level which would maximize the weight of the catch. One management goal is to increase the size and age of lobsters caught. This would allow many more juve niles to mature and thereby increase production of new lobsters. At the same time the larger juveniles caught would increase the landings (Fig. 4-1).
Surf clams and ocean quahogs are harvested with hydraulic dredging vessels; the majority of EEZ landings occur off New Jersey and the Delmarva Peninsula. Small quantities of surf clams and ocean quahogs are landed from southern New En- gland and the Gulf of Maine waters. Fisheries for these species are still closed on Georges Bank because of paralytic shellfish poisoning (PSP) contamination. Surf clams and ocean quahogs are managed under the Surf Clam and Ocean Quahog 
Figure 4-1.-U.S. American lobster landings, 1940-90, and the number of lobster traps fished in Maine coastal waters during that period. In 1990, Maine produced $46 \%$ of the U.S. landings of the species.

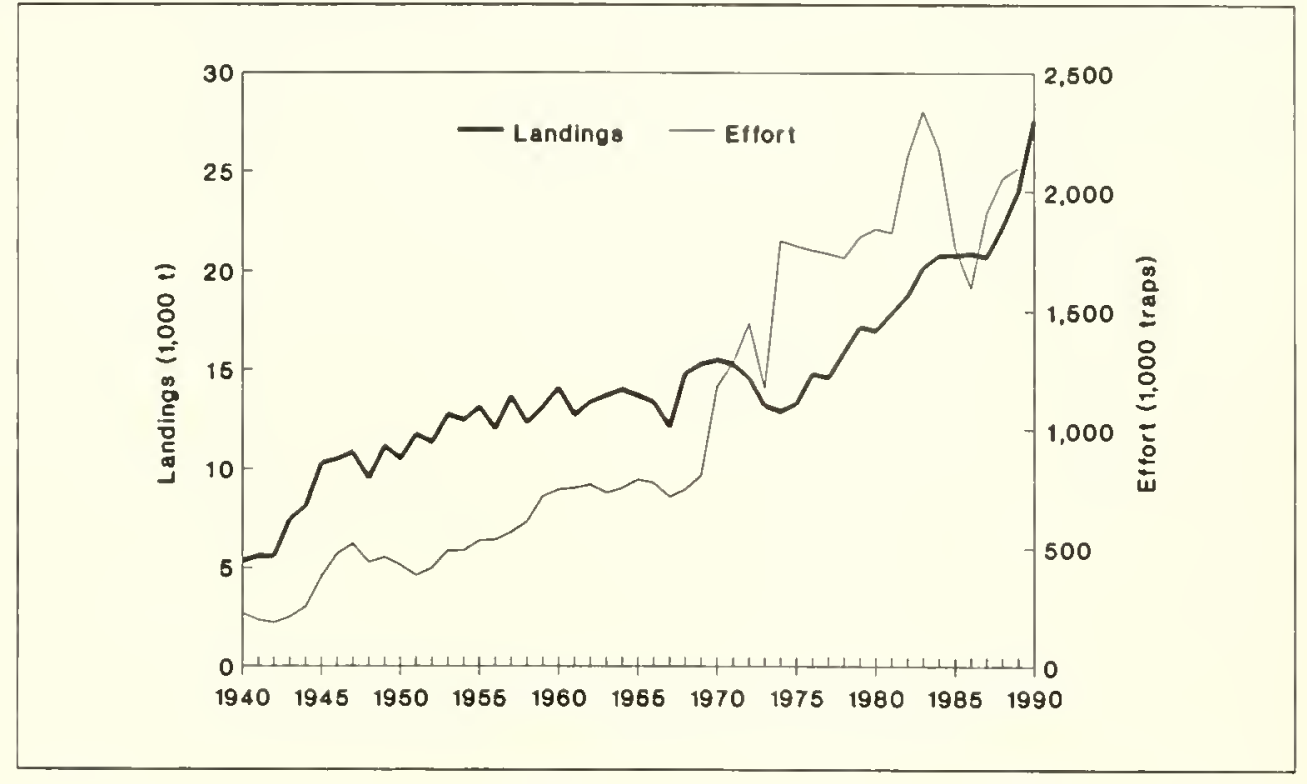

FMP of the Mid-Atlantic Fishery Management Council. The primary clam and quahog management measure is a system of individual transferable quotas (ITQ) allocated on the basis of historical participation in the fisheries. The development of this system is the first such allocation of property rights for management of living marine resources in U.S. waters.

Atlantic surf clam landings increased steadily from $11,400 \mathrm{t}$ in 1960 to $43,600 \mathrm{t}$ in 1974. Subsequent years of overutilization, combined with a large die-off along the New Jersey coast in 1976, led to very low stocks, and landings declined to $15,800 \mathrm{t}$ in 1979. Since 1977, the FMP has regulated total annual EEZ surf clam landings (where most are caught) and has addressed the problem of overcapitalization (too many boats and gear) in the fishery. Clams from good spawning seasons in 1976 and 1977 off New Jersey and the Delmarva Peninsu!a now comprise the bulk of the harvestable stocks. Under current harvest rates in the EEZ, there are enough surf clams to support current EEZ landings of 24,000 t well into the 1990's.

As surf clam populations collapsed in the mid-1970's, ocean quahog landings increased rapidly to fill the need for processed clam products. Landings increased from $600 \mathrm{t}$ in 1975 to the current level of 22,000 t. Ocean quahogs inhabit the Gulf of Maine, Georges Bank, and the relatively deep waters of the Mid-Atlantic continental shelf. In the cooler waters of the Gulf of Maine, they are found relatively near shore. The species is extremely slow growing, and quahogs over 100 years old are common in the populations (particularly in the MidAtlantic region). Current annual landings have been maintained at less that $2 \%$ of the estimated stock in view of its limited annual productivity.

\section{sea scallop}

Historically, sea scallop landings have fluctuated greatly in response to changes in production and fishing effort, recruitment variability, and changing effort patterns by U.S. and Canadian fishermen (Fig. 4-2). Good production in recent years brought increased fishing effort and record U.S. landings in 1990. Because scallops are fished when young, yield is far below what it could be if scallops were allowed to grow more before harvest. This situation is called "growth overfishing."
Sea scallops are harvested on the continental shelf from the Virginia Capes to The Hague Line (between the U.S. and Canadian portions of Georges Bank), and in the Gulf of Maine. Sea scallops are primarily dredged, though small quantities are taken with otter trawls and by divers (in the Gulf of Maine). The Sea Scallop FMP of the NEFMC regulates the fishery primarily by maximum-meat-count regulations intended to protect small scallops. 


\section{... Northeast Invertebrate Fisheries}

34

Figure 4-2.-U.S. and Canadian landings of Atlantic sea scallops in the northeastern U.S. and southeastern Canadian waters, 1940-90.

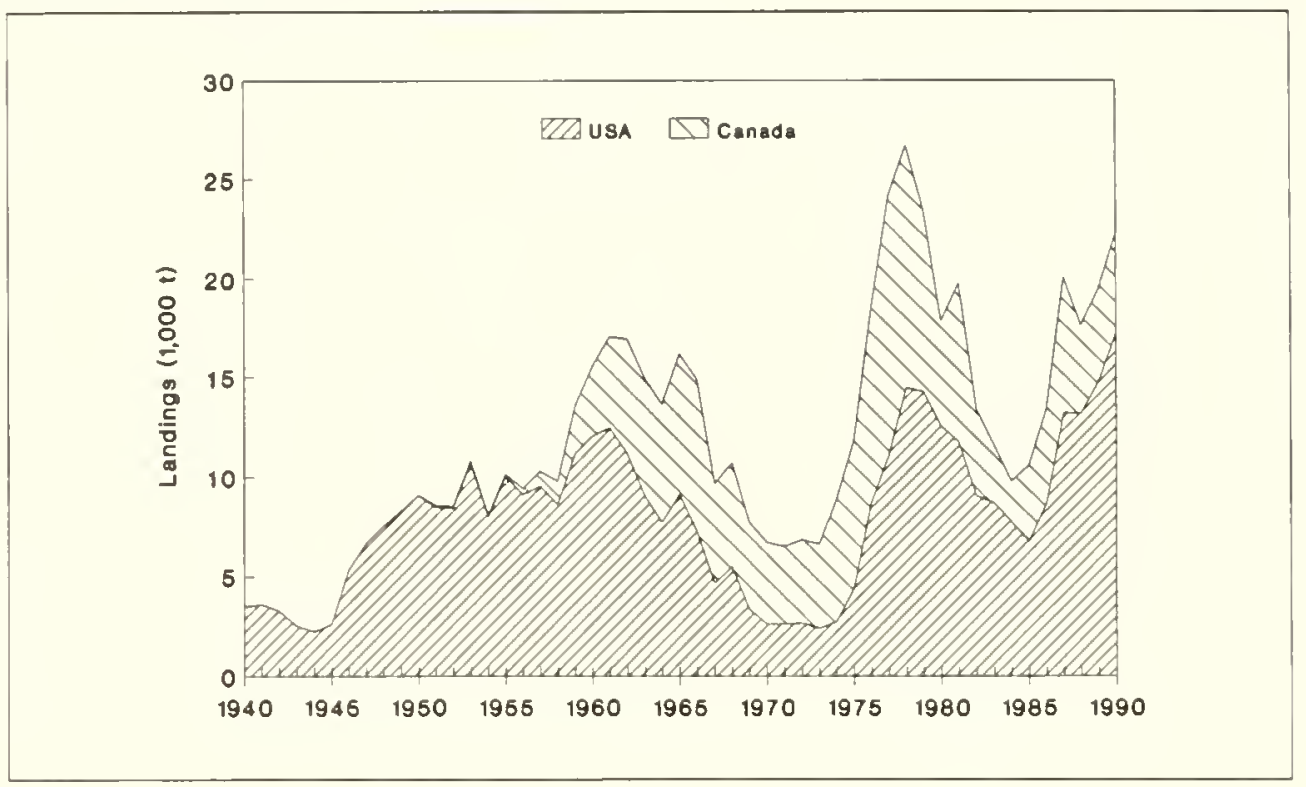

\section{Northern Shrimp}

The Atlantic States Marine Fisheries Commission (ASMFC) regulates the northern shrimp fishery in the Gulf of Maine; regulations control the season length (December to May) and the type of gear.

Northern shrimp are harvested exclusively from the Gulf of Maine with smallmesh trawls. Northern shrimp are at the southern extent of their geographical range in U.S. waters, and high abundance of small shrimp is generally a result of low water temperatures.

The Gulf of Maine fishery for northern shrimp has undergone a boom and bust cycle over the past 25 years. Landings peaked at 12,800 $t$ in 1969 but rapidly declined during the 1970's to a point where no fishing was allowed in 1978, under regulations of ASMFC. The rapid decline in abundance has been attributed both to overfishing and to unusually high water temperatures in the 1970's. Populations have rebuilt somewhat from the very low levels of the late 1970's. Recent landings have stabilized at about $4,000 \mathrm{t}$, and fishing mortality rates are now relatively low.

\section{ISSUES}

The sea scallop fishing mortality rate is far higher than that which would produce the maximum yield (i.e., growth overfishing). Current meat-count regulations have little control over total fishing mortality rates, but do offer some protection for 3-year-old scallops. Recent strong year-classes have increased U.S. landings to record levels (Fig. 4-2), but production has varied widely because the fishery is highly dependent on the incoming year-class each year.

American lobster management is complicated by the international trade in live lobsters between Canada and the United States. Conformity of imports with U.S. size limits is a major political issue. Despite growth in recent landings, the fishery is still almost completely supported by young lobsters just meeting the minimum size, and this is a source of serious concern for the long-term health and stability of the fishery. The relatively high lobster production in recent years provides an opportunity to increase the minimum legal lobster size with minimum short-term catch loss. This opportunity may not be available later, and future increases in legal size limits would be even more difficult to implement. Overall increases in lobster landings in most western Atlantic areas (a record of 27,000 $t$ in 1990) imply that they may be due more to favorable environmental conditions for young lobster survival than to the effects of fishery regulation. 
... ISSUES

An important continuing issue in the surf clam-ocean quahog fishery will be the implementation of the ITQ system which removed the need for complex catch and effort restrictions. There has been a beneficial reduction in the size of the surf clam fleet (from about 115 to 68 vessels) in the first six months under the ITQ system.

An important question complicating the long-term management of northern shrimp is the relative influence of fishing and environmental variability on populations. Under cooler water temperature regimes, juvenile survival and subsequent recruitment appear to be enhanced. In times of warmer water temperatures, husbanding the adult stock will tend to stabilize year-toyear landings fluctuation and preserve spawning biomass for more favorable environmental conditions.

Northern shrimp undergo a sex reversal, beginning as males and changing to females during their third year of life. Understanding the effects of harvesting on a species with such a life history pattern, particularly in relation to the size (age) at capture and the overall fishing mortality rate, is an important issue for developing management strategies.

Bycatch of undersized groundfish in the small-mesh trawl fishery targeting northern shrimp is an important and contentious management issue. The NEFSC Sea Sarnpling Program has documented the seasonal and temporal extent of bycatch of groundfish in the shrimp fishery. Potential bases for resolution of the bycatch problem include the development and use of trawls designed to retain shrimp while releasing groundfish ("separator trawls"), and temporal and spatial closures to minimize groundfish bycatch. 


\section{INTRODUCTION}

Migratory high-seas fishes (called "oceanic pelagics") аге caught for sport and/or commerce. In the Atlantic Ocean, swordfish and bluefin tuna have long provided important fisheries, while in recent years, yellowfin tuna have become important to U.S. fishermen.

\section{SPECIES AND STATUS}

Figure 5-1.-U.S. landings of tunas, swordfish, marlins, sailfish, and spearfish from the western North Atlantic Ocean, and the percentage of the total landings made up of the primary species (bluefin and yellow fin tuna and swordfish), 1961-90.
Important species include swordfish, bluefin tuna, yellowfin tuna, bigeye tuna, albacore, skipjack tuna, blue and white marlin, sailfish, longbill spearfish, and other minor fishes. Many anglers catch billfish, blue marlin, white marlin, and sailfish in U.S. waters and occasionally longbill spearfish. Commercial fishing for them in U.S. waters is now banned, but the species may be accidentally caught on tuna and swordfish longlines.

From the early 1960's through 1977 . U.S. fishermen averaged about $5,000 \mathrm{t}$ per year $(2,000-12,000 \mathrm{t} /$ year $)$ of oceanic pelagics (Fig. 5-1). Since 1978, U.S. fishermen have caught 8,000 t or more per year, and during 1987-89 they averaged 18,130 $t /$ year. However, the estimated current potential yield of oceanic pelagics is 13,335 $\mathrm{t} /$ year, and the long-term potential yield to the U.S. fleet is estimated at 23,471 $\mathrm{t}$ (Table 5-1).

Since 1960, the top species in the U.S. harvest has shifted from bluefin tuna to swordfish to yellowfin tuna (Fig. 5-1) as each species became increasingly overfished. In 1961-73, bluefin tuna repre- sented $45-80 \%$ of the U.S. western Atlantic catch. But since 1977, the percentage has dropped to less than $10 \%$, reflecting the crash in the bluefin tuna population (Fig. 5-1), catch restrictions, and the increasing harvests of alternate species. During 196173. swordfish represented $5-20 \%$ of the U.S. catch, rose to $60 \%$ in 1982 , but has since dropped to about 33\% (Fig. 5-1). During 1961-83, the percentage of yellowfin tuna in the U.S. North Atlantic catch was usually less than $10 \%$, but that has since risen to $45 \%$.

The U.S. dockside value of these fishes soared from about $\$ 20$ million (early 1980 's) to over $\$ 100$ million in 1988 . During 1987-89, the average annual dockside value was $\$ 96.5$ million.

Angler harvests of large pelagic fishes are hard to tally because their catch is comparatively small. Also, tagging and releasing of some species have grown in recent years, so fewer are landed. The average annual catch by anglers for 1987 89 is conservatively estimated at $1,900 \mathrm{t}$. Fishing tournament surveys indicate a substantial increase in billfish fishing since

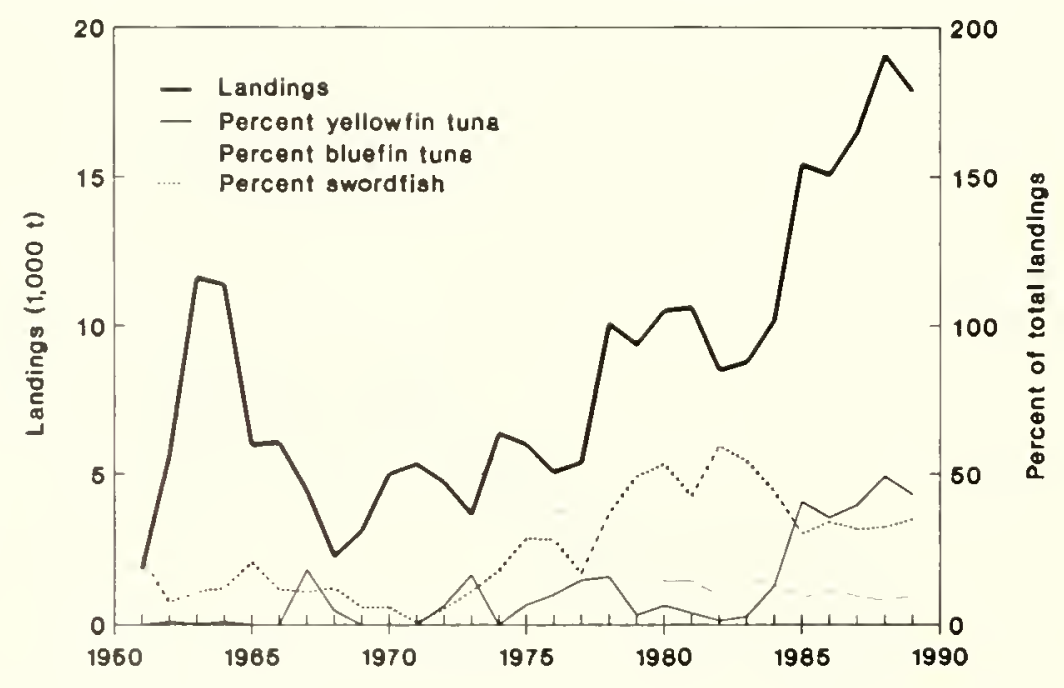


Table 5-1.-Recent average, current potential, and long-term potential yields in metric tons (t), and status of utilization of Atlantic highly migratory pelagic species. The LTPY, CPY, and RAY for the unit equals the sum of the species' LTPY's, CPY's, and RAY's. Where the species' LTPY is unknown, the species' CPY is substituted in the sum. If the species' CPY is unknown, the species' RAY is substituted.
Long-term potential yield (LTPY $)^{\prime}=$ Current potential yield $(C P Y)^{\prime}=$

Recent average yield $(\text { RAY })^{1.2}=$

\begin{tabular}{|c|c|c|c|c|}
\hline \multirow[b]{2}{*}{ Species and area } & \multicolumn{3}{|c|}{ Yield $(t)$} & \multirow{2}{*}{$\begin{array}{l}\text { Status of } \\
\text { utilization }\end{array}$} \\
\hline & RAY $^{2.3}$ & $C P Y^{2}$ & LTPY2 & \\
\hline Bigeye tuna (Atlantic) & 55,600 & Unknown & 70,800 & Under \\
\hline Albacore (N. Atlantic) & 34,566 & Unknown & 48,000 & Full \\
\hline Yellowfin tuna (W. Atlantic) & 28,267 & Unknown & 31,000 & Unknown \\
\hline Skipjack tuna (W. Atlantic) & 26,200 & Unknown & 33,000 & Full \\
\hline Swordfish (N. Atlantic) & 18,896 & 5,300 & 16,000 & Over \\
\hline Bluefin tuna (W. Atlantic) & 2,900 & 2,000 & 11,000 & Over \\
\hline \multicolumn{5}{|l|}{ Billfishes } \\
\hline Blue marlin (N. Atlantic) & 773 & Unknown & 2,400 & Full \\
\hline White marlin (N. Atlantic) & 351 & Unknown & Unknown & Unknown \\
\hline Sailfish (W. Atlantic & 812 & Unknown & Unknown & Full \\
\hline Other tunas (Atlantic) & 57,700 & Unknown & Unknown & Unknown \\
\hline
\end{tabular}

'Total LTPY, CPY, and RAY based only on the U.S portion of the yield under present fishing patterns.

${ }^{2} 1988-90$ average.

${ }^{3}$ Individual LTPY's, CPY's, and RAY's based on entire stock, regardless of harvesting nation.

\section{... SPECIES AND STATUS}

1972, though there are no precise data on these anglers. Billfish tournament growth in some southern states indicates a fivefold to tenfold increase in this fishery since 1972. More data are needed, however, to quantify the recreational fishery trends for these fishes in the U.S. Atlantic and Gulf waters.

At least two Atlantic pelagic species are far overutilized. Recent swordfish harvests have heightened the risk of a population collapse: Though international swordfish protection rules have been adopted, they may not prevent serious production losses. Bluefin tuna have been overharvested, severely reduced, and harvest cuts were implemented in 1982. However, there has been no apparent increase in adult numbers, and, indeed, it appears that spawning stocks continue to decline.

Atlantic oceanic pelagic fishes migrate widely, and they are harvested over broad oceanic areas by both U.S. and foreign commercial and recreational fishermen. Thus, both national and international management are mandatory for their survival. In all cases, scientific stock assessments provide the bases for regulations. The U.S. fleets fish from the northwestern Atlantic Ocean through the Caribbean Sea and the Gulf of Mexico. When in U.S. jurisdiction, they may be regulated under the Magnuson Fishery Conservation and Management Act (MFCMA) as well as international agreements through the International Commission for the Conservation of Atlantic Tunas (ICCAT).

U.S. fishery management plans have been developed for swordfish, blue marlin, white marlin, sailfish, and spearfish under the MFCMA. International regulations are being adopted for swordfish for the high seas. Bluefin tuna fishing has been regulated for nearly a decade.

\section{ISSUES}

Management of such highly migratory spe cies is difficult. Domestic regulation alone, without international agreements, has limitations. On the other hand, international agreements are difficult to achieve if the primary fishing nations cannot agree on fishing and conservation objectives. Some nations see such rules as too restrictive of short-term gains, while others see them as too lax for long-term conservation.

Other oceanic pelagics, notably yellowfin tuna, blue marlin, white marlin, 
and sailfish, are subjects of U.S. concern. Marlin and sailfish bycatches in tuna and swordfish fisheries are a problem, especially as commercial fisheries move into concentrations of billfishes important to anglers. Meanwhile, expansion of the U.S. longline fishery for Gulf yellowfin tuna and Spanish longline fishing in the tropical eastern Atlantic have heightened concern for distressed Atlantic tunas, swordfish, and the billfishes sought by anglers. 


\section{INTRODUCTION}

Figure 6-1.-U.S. commercial and recreational landings and abundance indices of large and small coastal Atlantic sharks, 1979-90.
About 350 species of sharks are known worldwide, and 72 frequent U.S. waters along the Atlantic coast, Gulf of Mexico, Puerto Rico, and the U.S. Virgin Islands. Sharks have been fished in limited coastal areas for many years, but the large coastal sharks have been intensively fished only a few years. Sharks were first fished primarily for their livers (liver oil for vitamin A) and hides (for leather). Other minor products were fresh and salted meat, dried fins (for Oriental sharkfin soup), and fish meal.
The appearance of low cost, synthetic vitamin A ended some of the small shark fisheries in 1950. Very little shark was eaten in the United States before 1970. Since then, shark has become popular due to better handling, marketing and promotion, and an economy favoring low-cost shark over more expensive fish. Very recently, however, high levels of mercury have been found in some sharks which has destabilized the shark market (Fig. 6-1).
SPECIES AND STATUS
Under the Magnuson Fisheries Conservation and Management Act (MFCMA), U.S. Atlantic sharks have been divided into three management groups (Table 6-1): 1) Large coastal sharks (white, tiger, lemon, smooth and great hammerhead, basking. whale, blacktip, sandbar, reef, dusky, spinner, silky, bull, bignose, Galapagos, night, ragged tooth, nurse, and scalloped), 2) small coastal sharks (Atlantic and Caribbean sharpnose, finetooth, blacknose, bonnethead, and Atlantic angel), and 3) pelagic sharks (longfin and shortfin mako, blue, porbeagle, thresher, bigeye thresher, oceanic whitetip, sevengill, sixgill, and big. eye sixgill).

Both U.S. recreational and commercial shark fishermen seek coastal sharks along the Atlantic seaboard. Pelagic sharks are targeted by tournament anglers, particu- larly off the Mid-Atlantic states, and are incidentally caught by swordfish and tuna longliners. The dockside value of the commercial shark fisheries has averaged about $\$ 7$ million annually in recent years.

Anglers fish for sharks on both tournament and nontournament trips, the latter being the more prevalent. Nontournament anglers usually catch small coastal sharks that are generally not targeted by commercial fisheries. However, commercial and recreational fishermen can affect the shark fishing of each other. The Gulf shrimp fishery catches and discards many small coastal sharks (mostly sharpnose). Also, headboat anglers depend on blacktip sharks, a species seasonally taken by longline and drift gillnet fishermen. Many southern shark tournament anglers also fish for the same large coastal species 


\section{... Atlantic shark Fisheries}

40

Table 6-1.-Recent average, current potential, and long-term potential yields in metric tons ( $t)$, and status of utilization for Atlantic sharks. The LTPY, CPY, and RAY for the unit equals the sum of the species' LTPY's, CPY's, and RAY's. Where the species' LTPY is unknown, the species' CPY is substituted in the sum. If the species' CPY is unknown, the species' RAY is substituted.

Long-term potential yield (LTPY) $=\quad 9,730 \mathrm{t}$

Current potential yield $($ CPY $)=\quad 7.630 \mathrm{t}$

Recent average yield $(\text { RAY })^{1}=\quad 9.530 \mathrm{t}$

\begin{tabular}{|c|c|c|c|c|}
\hline \multirow[b]{2}{*}{ Species and area } & \multicolumn{3}{|c|}{ Yield $(t)$} & \multirow{2}{*}{$\begin{array}{l}\text { Status of } \\
\text { utilization }\end{array}$} \\
\hline & RAY $^{2,3}$ & CPY2 & LTPY $^{2}$ & \\
\hline Large coastal sharks ${ }^{2}$ & 3,800 & 1,900 & 3.400 & Over \\
\hline Small coastal sharks 3.4 & 3.000 & 3,000 & 3.600 & Under \\
\hline Pelagic sharks 5 & 2,730 & Unknown & Unknown & Unknown \\
\hline
\end{tabular}

'198890 average.

IIncludes sandbar, reef, blacktip. dusky, spinner, slky, bull, bignose, Galapagos, night, tiger, lemon, ragged tooth, nurse, scalloped, smooth and great hammerhead, whale, basking, and white sharks.

${ }^{3}$ Includes Atlantic and Caribbean sharpnose, finetooth, blacknose, bonnethead, and Allantic angel sharks.

${ }^{4}$ Almost all of the small coastal shark yield is caught as bycatch in the Gulf shrimp fishery and discarded at sea.

Includes longfin and shortfin mako, blue, porbeagle, thresher, bigeye thresher, oceanic whitetıp, sevengill, sixgill, and bigeye sixgill sharks.

taken by commercial fishermen. Tournament anglers further north (Mid-Atlantic states and southern New England) fish for shortfin mako and blue sharks that are caught incidentally by large pelagic longline fisheries. In another twist, sharks taken by anglers along the Atlantic and Gulf coasts are often sold to commercial fish buyers (in 1986 about $9 \%$ of the "commercial" landings were taken by rod-and-reel fishermen).

Meanwhile, a mobile longline fishery targets large coastal sharks in both Atlantic and Gulf waters, taking several species important to anglers. Fish buyers prefer sharks of $15-50$ pounds (dressed weight), but larger sharks may be killed just for their fins.

Other boats use gill nets, including drift gill nets, for blacktip shark near shore in late summer and early auturnn. Gulf snapper-grouper boats, particularly bottom longliners, also land sharks. Many sharks caught by Gulf shrimp trawlers are discarded at sea (though fins may be saved), but large valuable sharks are kept and sold.

Many sharks are also caught in the pelagic swordfish and tuna longline fishery. Worth little or nothing, most of these sharks are discarded at sea, though shortfin mako are regularly landed owing to their market value.

\section{ISSUES}

Recreational and commercial fishermen have both voiced concern about declining shark populations. Sharks live 30-40 years or more, they grow and reproduce slowly, and therefore they are very vulnerable to overutilization. Finning, a common commercial fishing practice of removing fins from sharks and discarding the rest of the shark overboard, has been criticized. Another problem is a critical lack of data on shark numbers, biology, distribution, life history, and harvest. Without this data, it is difficult to address shark problems. 


\section{INTRODUCTION}

Figure 7-1.-Atlantic coast migratory pelagic fish landings and abundance (biomass) indices for king and Spanish mackerels, 1979-90.
"Coastal pelagic" fishes, which range from the shore to the outer edge of the U.S. continental shelf, include king, Spanish, and cero mackerel; dolphin fish, and cobia. They are found from the Gulf of Maine southward into Cuban, Central American, and Brazilian waters.

In general, coastal pelagics swim fast, form schools, feed voraciously, grow rapidly, mature rather early, and spawn for extended periods of time. They are sought by both sport and commercial fishermen who, respectively, caught $8,000-17,000 \mathrm{t}$ and $5,000-10,000 \mathrm{t} /$ year during 197989 (Fig. 7-1).

U.S. and Mexican commercial fishermen have fished Spanish mackerel since the 1850 's and king mackerel since the 1880's. The Spanish mackerel fishermen began fishing near New York and New Jersey with trolling gear, but the most commonly used gear since the 1950's has been the gill net, especially the runaround gill net. About 1900, the U.S. fishery shifted southward until most of the commercial harvest was taken in the southern and Gulf states, as it is today. In 1990 , over $90 \%$ of the commercial catch was landed in Florida. The Spanish mackerel recreational fishery is equally significant, and anglers now catch about half of all the Spanish mackerel taken.

Commercial king mackerel fishermen have used gill nets, troll lines, handlines, purse seines, otter trawls, and pound nets. Runaround gill nets and troll lines were the primary gears used in Florida until the late 1970's, when purse seines began to boost harvests. Purse seines are now banned under the Coastal Pelagic Fishery Management Plan (CPFMP). King mackerel are commercially fished from Chesapeake Bay southward. Four major production areas are North Carolina; Port Salerno to Sebastian, Fla.; the Florida Keys; and Naples, Fla. Grande Isle, La., a fifth area until the early 1980's, was believed to harbor older females and serve as a major spawning ground for Gulf king mackerel. Catch was believed to be very high on these fish during the late 1970's and early 1980's. Few fish are now taken in this region and it no longer contributes much to the fishery. A large king mackerel sport fishery also exists off Panama City, Fla., and off other southeastern states. Sport landings are thought to have been hurt by the expanding commercial fisheries in the 1970's that were mostly unregulated until the 1980's.

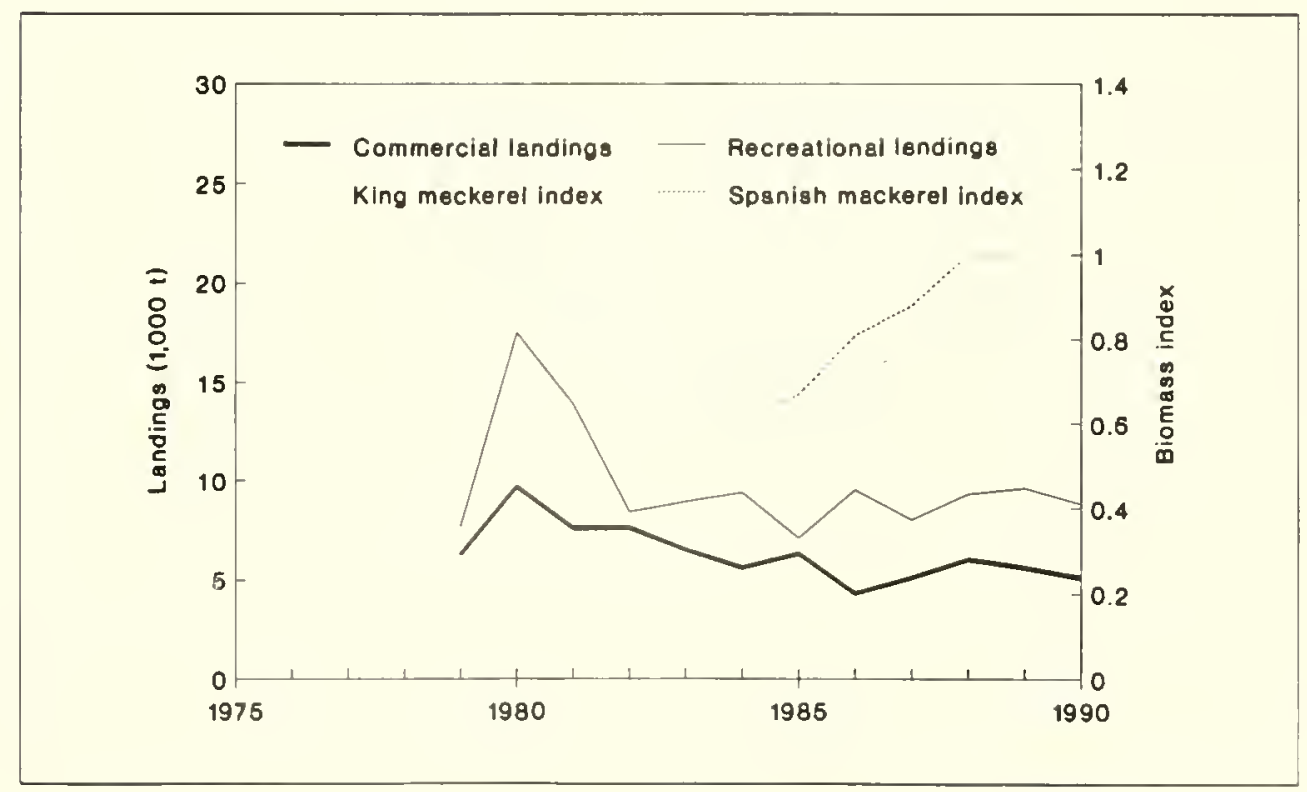


SPECIES AND STATUS
Table 7-1.-Recent average, current potential, and long-term potential yields in metric tons ( $t$ ), and status of utilization of Atlantic coastal migratory pelagic fishes. The LTPY, CPY, and RAY for the unit equals the sum of the species' LTPY's, CPY's, and RAY's. Where the species' LTPY is unknown, the species' $C P Y$ is substituted in the sum. If the species' CPY is unknown, the species' RAY is substituted.
Atlantic dolphin and cobia sport fisheries produce more than $90 \%$ of the total annual yield of coastal pelagic species. Some cobia are incidentally caught by commercial mackerel fishermen. Cero mackerel are unimportant and are usually taken in other fisheries.

Coastal pelagic fishes (mackerels, cobia, and dolphin) are managed under the joint CPFMP and regulations adopled by the Mid-Atlantic, South Atlantic, and Gulf of Mexico Fishery Management Councils. Although Mexican catches are believed large, only U.S. fishermen are now regulated. King and Spanish mackerel catches have been limited under increasingly restrictive Federal management since 1982, along with a similar tightening by the states. Dolphin and cobia are managed through minimum fish size and creel limits; cero mackerel fishing is minimal and unregulated.

This group as a whole now yields only about $53 \%$ of its long-term potential (Table 7-1), and many species are fished near or over maximum production levels. Three of the four mackerel stocks are overutilized and have been under a rigid rebuilding schedule since 1983.

The Gulf king mackerel stock, likely the one with the largest long-term potential, is also severely depressed and is producing the least. Recent average annual production is at $25 \%$ of its maximum level; stock reduction was due to excessive harvests from the late 1970's through the early 1980's. Liberal fishing rules and sparse data hampered conservation until 1986.

The Atlantic king mackerel group is near maximum production. Spanish mackerel are below maximum production levels, but are recovering. The status of cobia and dolphin in the southeastern Atlantic is unclear. They are mostly caught by anglers, but the data needed to assess long-term production do not exist.

\begin{tabular}{|c|c|c|c|c|}
\hline \multicolumn{2}{|c|}{$\begin{array}{l}\text { Long-term potential yield (LTPY) }= \\
\text { Current potential yield }(C P Y)= \\
\text { Recent average yield }(\text { RAY })^{1}=\end{array}$} & \multicolumn{2}{|c|}{$\begin{array}{l}28,283 t \\
20,980 t \\
14,881 t\end{array}$} & \multirow{3}{*}{$\begin{array}{l}\text { Status of } \\
\text { utilization }\end{array}$} \\
\hline \multirow[b]{2}{*}{ Species and area } & \multicolumn{3}{|c|}{ Yield $(t)$} & \\
\hline & RAY ${ }^{1}$ & CPY & LTPY & \\
\hline Dolphin & 4,170 & Unknown & Unknown & Unknown \\
\hline \multicolumn{5}{|l|}{ King mackerel } \\
\hline Gulf of Mexico & 2,413 & 2,670 & 9,750 & Over \\
\hline Atlantic & 2,942 & 5,221 & 3,632 & Under \\
\hline \multicolumn{5}{|l|}{ Spanish mackerel } \\
\hline Gulf of Mexico & 1,934 & 4,722 & 5,457 & Over \\
\hline Atlantic & 2,403 & 3,178 & 3.715 & Over \\
\hline Cobia & 997 & Unknown & Unknown & Unknown \\
\hline Cero mackerel & 22 & Unknown & Unknown & Unknown \\
\hline
\end{tabular}

'1988-90 average.
Management of coastal pelagic species will require the coordination of Federal, state, and international regulatory actions to accommodate the migratory behavior of the mackerels.
The allocation of the yield between recreational and commercial users remains an issue. This has become particularly critical because the mackerel population has declined. 


\section{INTRODUCTION}

\section{SPECIES AND STATUS}

Figure 8-1.-Recreational and commercial reef fish landings from the Gulf of Mexico and the index of abundance of young red snappers, 1979-90.
The term "reef fishes" includes species that prefer coral reefs, artificial structures or other hard bottom areas, and tilefishes that prefer sandy bottom areas. They range from the coast to about $150 \mathrm{~m}$ depth, depending on the species and area.

Ecologically, reef fish fisheries are integrated with such other fisheries as spiny lobster, conch, stone crab, corals, "live" rock, and ornamental aquarium fishes. Nonconsumptive uses of reef resources (i.e., ecotourism, sport diving, education, and scientific research) are also economically important and can conflict with commercial or recreational fisheries.
Reef fish fisheries vary greatly by location and species; they are extremely complex and have many users: Commercial, artisanal, recreational, and scientific. Anglers specialize in fishing for food, sport, and trophies, and operate from charterboats, headboats, private boats, and shore, using fish traps, hook and line, longlines, bandit rigs, spears, trammel nets, and barrier nets.

Reef fish have been caught for centuries, but good statistical data for most areas began in the late 1970's when recreational fishery surveys were started. Fishery data collection remains difficult owing to diverse user groups, broad geographical areas, and the many ports where fish are landed. Fishing pressure has increased with growing human populations, greater demands for fishery products, and technological improvements, such as longlines, wire fish traps, electronic fish finders, and navigational aids.
Reef fisheries vary widely by area. In most cases, the current and long-term potential yields are unknown, though for many species they are probably higher than present average yields would indicate (Table 8-1). For example, the recent Puerto Rican 3-year average landings for most species were only a small fraction of the highest reported annual landings. In many cases, data are not available by species, fishery component, or area. Statistics are confounded because species are easily misidentified owing to similar appearances.

More than 100 reef fishes are important to commercial or sport fishermen (Table $8-1)$. While landings and value for individual species are not large, reef fishes overall produce significant landings and values (Fig. 8-1, 8-2). Recent average commercial catches for the U.S. Atlantic and Gulf have been about 9,000 t with a dockside value of $\$ 48$ million. Sport fishermen make

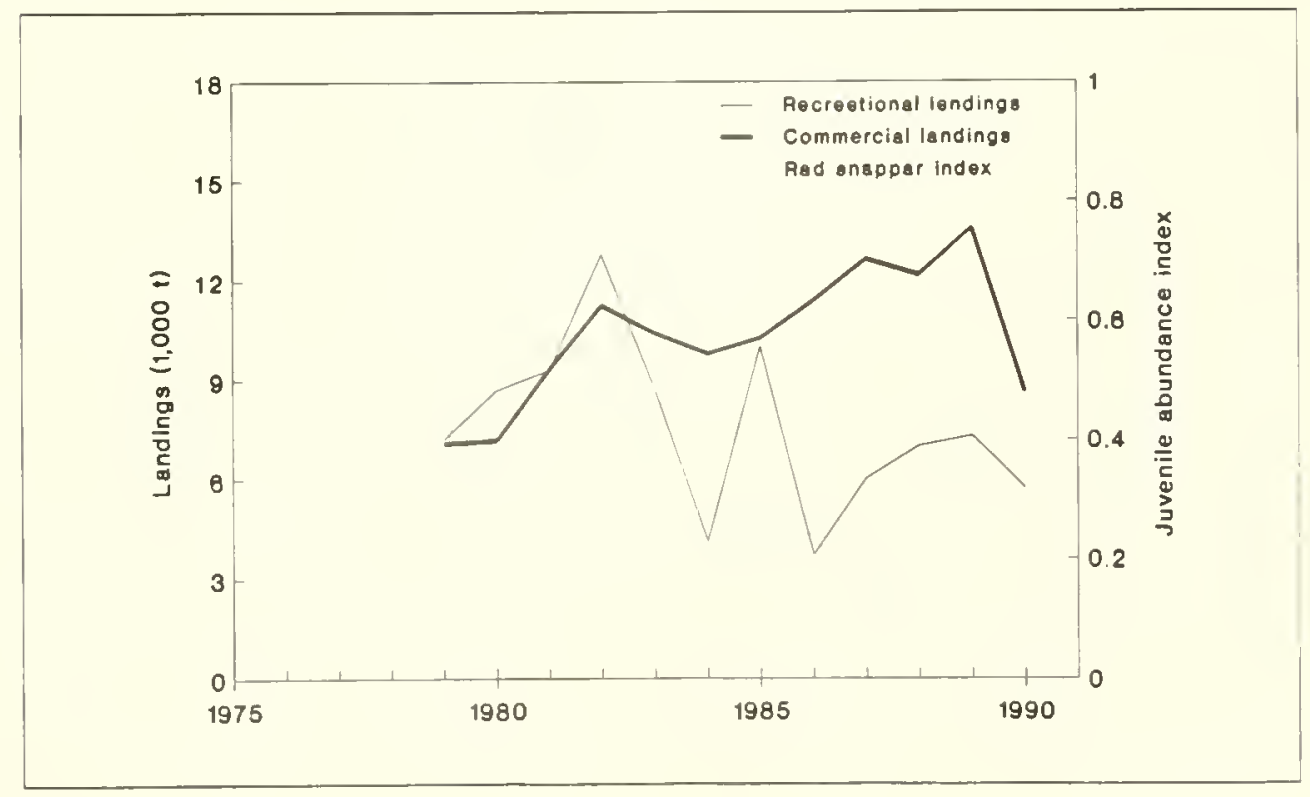




\section{... Atlantic/Gulf of Mexico/Caribbean Reef Fish Fisheries}

44

Table 8-1.- Recent average, current potential, and long-term potential yields in metric tons $(t)$, and status of utilization of Atlantic, Gulf of Mexico, and Caribbean reef fishes. The LTPY, CPY, and RAY for the unit equals the sum of the species' LTPY's, CPY's, and RAY's. Where the species' LTPY is unknown, the species' CPY is substituted in the sum. If the species' CPY is unknown, the species' RAY is substituted.
Long-term potential yield $(\text { LTPY })^{1}=$
$41,404 \mathrm{t}$
Current potential yield $(\text { CPY })^{\dagger}=\quad 28,065 \mathrm{t}$
Recent average yield $(\text { RAY })^{2}=\quad 28,366 t$

\begin{tabular}{|c|c|c|c|c|}
\hline \multirow[b]{2}{*}{ Area and species } & \multicolumn{3}{|c|}{ Yield $(t)$} & \multirow{2}{*}{$\begin{array}{l}\text { Status of } \\
\text { utilization }\end{array}$} \\
\hline & RAY $^{2}$ & $\mathrm{CPY} Y^{\prime}$ & LTPY $^{\top}$ & \\
\hline
\end{tabular}

Gulf of Mexico

Red snapper

Red grouper

Nassau grouper and jewfish ${ }^{3}$

Shallow groupers (7 species)

Other groupers ( 5 species)

Other snappers ( 14 species)

Porgies (6 species)

Amberjacks (2 species)

Grunts ( 3 species)

5ea basses ( 3 species)

Others (16 species)

Atlantic

Wreckfish

Vermilion snapper

Red snapper

Red porgy

Nassau grouper and jewfish ${ }^{3}$

Other groupers (16 species)

5 ea basses ( 3 species)

Other snappers ( 12 species)

Amberjacks (2 species)

Other porgies ( 8 species)

Grunts ( 11 species)

Others (12 species)

Caribbean

Nassau grouper and jewfish ${ }^{3}$

5 nappers (10 species)

Other groupers (6 species)

Grunts ( 5 species)

Others (50 species)

1,800
Unknown
0
Unknown
Unknown
Unknown
Unknown
Unknown
Unknown
Unknown
Unknown
Unknown
Unknown
Unknown
Unknown
0
Unknown
Unknown
Unknown
Unknown
Unknown
Unknown
Unknown
Unknown
Unknown
Unknown
Unknown

15,000

Unknown

Unknown

Unknown

Unknown

Unknown

Unknown

Unknown

Unknown

Unknown

Unknown

Unknown

Unknown

450

Unknown

Unknown

Unknown

Unknown

Unknown

Unknown

Unknown

Unknown

Unknown

Unknown

Unknown

Unknown

Unknown
Unknown
Over

Unknown

Over

Over

Unknown

Unknown

Unknown

Unknown

Unknown

Unknown

Unknown

Full

Over

Over

Over

Over

Over

Unknown

Over

Unknown

Unknown

Unknown

Unknown

Over

Unknown

Unknown

Unknown

Unknown

'LTPY is probably greatly understımaled and CPY overestımated, although potentıal production estımates are not available for most species groups, many are probably overutilized

${ }^{2} 1988-90$ average

${ }^{3} \mathrm{~A}$ total fishing prohibition has been imposed or is being considered

... SPECIES AND STATUS more than 20 million angler-trips annually.

The reef fish management unit includes about 100 species (excluding those for the marine aquarium trade). In the southeastern U.S. region, the unit is managed by three councils for Federal waters, eight states, the U.S. Virgin Islands, and Puerto Rico.

Reef fishes are vulnerable to overfishing owing to their long lives, slow growth, ease of capture, large body size, delayed reproduction, and other factors. Most are probably fully- and overutilized (Table 8-1). Red snapper, traditionally the most important
Gulf reef fish, is overutilized in part as a result of its incidental catch by the shrimp fishery. Eight of the ten major species in the Atlantic headboat fishery show significant size declines since 1972. In the Caribbean, such traditional fishery mainstays as Nassau grouper have practically disappeared, and total landings of species of more recent importance like the red hind have declined since the late 1970's (Fig. 8-3). Landings of amberjack, lane snapper, vermilion snapper, and similar species have increased as catches of traditional species have declined. 
Figure 8-2.-Recreational and commercial reef fish landings from the southeastern U.S. Atlantic coast and the index of abundance (average weight) of gag grouper, 1979-90.
Figure 8-3.-U.S. reef fish landings from Caribbean waters, 1978-89.
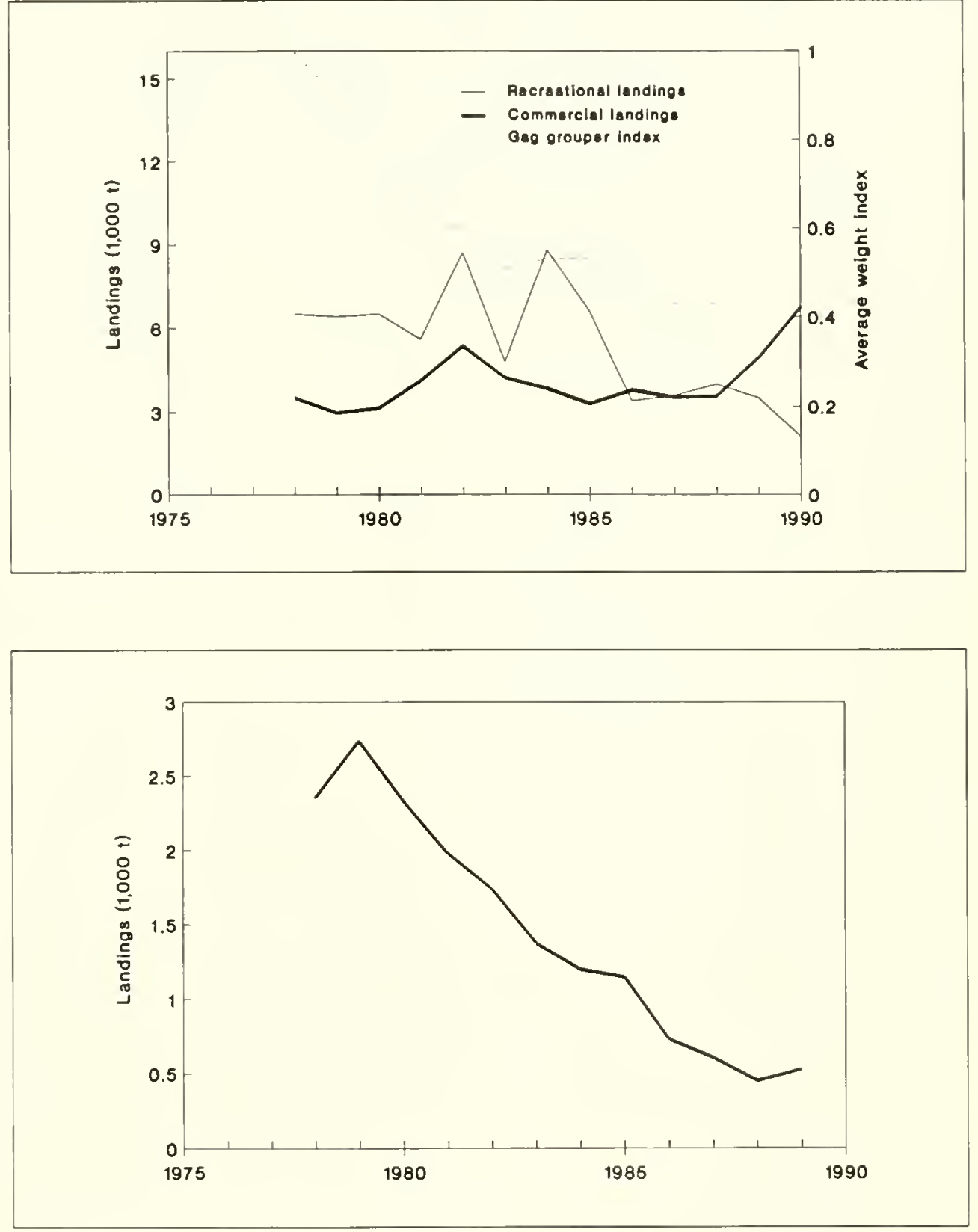

\section{ISSUES}

Proper fish identification is one of several severe problems that complicates the as sessment of individual reef fish species. Many reef fishes are similar in color, size, shape, etc., and are hard to tell apart. Catch data, therefore, do not reflect the catch by species. Even identifying species caught by anglers is difficult. Aging and other sampling techniques are also complicated by identification problems.

Another problem that affects reef fish stocks is that fish traps catch different species indiscriminately and can continue to catch fish even if traps are lost. However, regulations have eliminated traps in some areas.

Virtually all assessed reef fish stocks are overutilized. Unfortunately, potential production estimates do not exist and the exact status of most stocks is unknown.

As fish numbers have dropped, "sequential overharvesting" has occurred, as fishermen have shifted their effort to new species. Examples are the move to wreckfish in the Atlantic or to amberjack in the Gulf and Atlantic from other historically 


\section{... ISSUES}

sought reef fishes. Likewise, grunts and triggerfish have become a large part of certain southeastern U.S. recreational and commercial fishery harvests as traditional species declined. Red snapper reproduction has been hampered by two factors: 1) Heavy fishing on adult snappers and 2) the incidental catch and discards by shrimp trawlers. The sharp drop in the average size of red snapper now seen usually reflects high mortalities and population declines.

Research and management issues of concern are: 1) Bycatch losses of red snappers and other species in shrimp fisheries, 2) losses of undersized fishes caught in deep water, 3) proper stock identification, 4) unknown reasons for recruitment variability, 5) unknown long-term potential yield by area and species, 6) recovery of overfished stocks (i.e., jewfish, Nassau grouper, red snapper), 7) assessing fishing and bycatch take by longlines, wire fish traps, etc., 8) assessing the value of marine fishery reserves in managing reef fisheries, 9) determining effects of habitat alteration or degradation (e.g., sea grasses, coral reefs, mangroves, estuaries) on fish stocks, and 10) balancing traditional fisheries use with alternative uses such as ecotourism and sport diving. 


\section{INTRODUCTION}

The drum family includes several commercially and recreationally important fishes that have been fished since at least the late 1800's when commercial landings were first estimated. Thus, some of the fisheries are over a century old, while others have become more popular in recent years, as with the recent popularity of "blackened redfish" which stimulated demand for red drum.

\section{SPECIES AND STATUS}

Important species in this group are Atlantic croaker, spot, red drum, black drum, kingfishes (whiting), and spotted and other seatrouts. Commercial drum landings peaked in 1956 at over $32,000 \mathrm{t}$, more than $20,000 \mathrm{t}$ above the 1953 level. That great increase was stimulated by development of the pet food industry in the northern Gulf of Mexico. Atlantic croaker was sought for pet food as well, and about $76 \%$ of the associated landings were croaker and sand and silver seatrout. This pet food catch was reported with the "industrial fishery" data after 1956, and estimates of its size and value have since been unavailable. Status and potential yields for these species are given in Table 9-1.

The catch value of this group for human consumption was about $\$ 10$ million in 1978. This increased to about $\$ 22$ million in 1986, largely as a result of an increase in the price of the fish.

The overall sport catch of these species has been about equal to the commercial harvest for human consumption (Fig. 9-1). Most are harvested in state waters and are therefore under state management. In recent years, several states have set regulations favoring recreational use of some species, such as the red drum.
Commercial adult red drum purse seining in Federal Gulf of Mexico waters developed rapidly in the middle 1980's as demand grew for "blackened redfish." Before that, nearly all red drum were harvested near shore (in state waters) as juveniles. But as the offshore fishery developed, it became clear that the schooling adult redfish were extremely vulnerable to heavy harvests. Analyses showed that long-term potential yields for this fishery required limiting the harvest to the larger adult fish. In addition, greater inshore redfish catches by recreational and commercial fishermen, complicated by other factors, had cut the number of young fish that could have replenished offshore adult stocks.

Eventually a Red Drum Fishery Management Plan was developed for Gulf and, later, Atlantic waters. Both plans ban red drum fishing in Federal waters until the adult population increases in size. This effectively bars a significant adult red drum fishery in Federal waters as long as state rules favor substantial inshore fishing for young red drum. State actions so far have preserved inshore harvests and allocated most or all of the catch to sport fishermen.
Table 9-1.--Recent average, current potential, and long-term potential yields in metric tons $(t)$, and status of utilization of drum, croaker, and related species. The LTPY, CPY, and RAY for the unit equals the sum of the species' LTPY'S, CPY's, and RAY's. Where the species' LTPY is unknown, the species' CPY is substituted in the sum. If the species' CPY is unknown, the species' RAY is substituted.

$\begin{array}{ll}\text { Long-term potential yield }(\text { LTPY })^{\prime}= & 75,934 \mathrm{t} \\ \text { Current potential yield }(\mathrm{CPY})^{\prime}= & 25,808 \mathrm{t} \\ \text { Recent average yield }(\mathrm{RAY})^{2}= & 25,808 \mathrm{t}\end{array}$

\begin{tabular}{|c|c|c|c|c|}
\hline \multirow[b]{2}{*}{ Species and area } & \multicolumn{3}{|c|}{ Yield (t) } & \multirow{2}{*}{$\begin{array}{l}\text { Status of } \\
\text { utilization }\end{array}$} \\
\hline & RAY $^{2}$ & $\mathrm{CPY}^{1}$ & LTPY' & \\
\hline Black drum & 6,128 & Unknown & Unknown & Unknown \\
\hline Atlantic croaker & 4,946 & Unknown & 50,000 & Over \\
\hline Spot & 3,336 & Unknown & Unknown & Unknown \\
\hline \multicolumn{5}{|l|}{ Red drum } \\
\hline Gulf of Mexico & 2,828 & 2.828 & 7,900 & Over \\
\hline Atlantic & 626 & Unknown & Unknown & Over \\
\hline Seatrouts & 6.250 & Unknown & Unknown & Unknown \\
\hline Kingfishes (whiting) & 9.694 & Unknown & Unknown & Unknown \\
\hline
\end{tabular}

'LTPY is probably underestumated and CPY overestumated, although potenlial production estımates are not avaılable for some species groups, it is expected that they may be overulilized.

${ }^{2}, 98890$ average 


\section{Southeast Drum and Croaker Fisheries}

Figure 9-1.-U.S. drum and groundfish landings from southeastern U.S. coastal waters and the red drum recruitment index for the Gulf of Mexico, 1970-90.

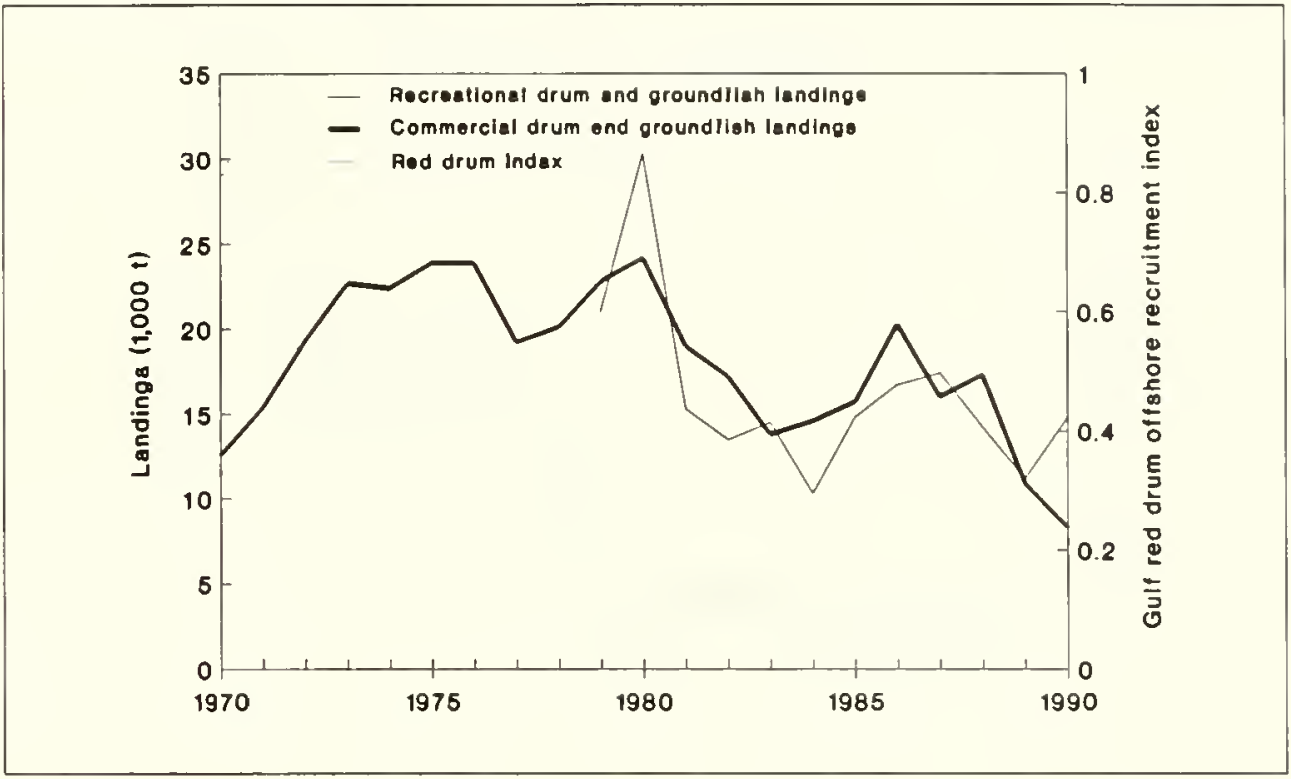

Efficient and economical means of reducing the bycatch of finfish in the shrimp fishery need to be developed. Large numbers of Atlantic croakers, spot, and sand and silver seatrout are also caught and killed in the shrimp fishery. Estimates of the $1972-89$ bycatch in the Gulf's offshore shrimp fishery averaged about 500 million spot, 1 billion seatrout, and 7.5 billion croaker. These species constitute the bulk of the offshore bycatch of finfish which averaged about 175,000 t during the 1980's. 


\section{INTRODUCTION}

Menhaden, important commercial fishes, are found in both coastal and estuarine Atlantic and Gulf of Mexico waters. Menha- den are food for many other fishes and sea birds. The butterfish fishery remains small and undeveloped.

\section{SPECIES AND STATUS}

\section{Atlantic Menhaden}

Figure 10-1.-U.S. menhaden landings from the Gulf of Mexico and southeastern Atlantic coast, 1950-90, and stock biomass estimates.
The Atlantic and the Gulf menhaden form large surface schools that support a huge "industrial" fishery which produces fish meal, oil, and soluble proteins. The industry is vertically integrated, generally with company-owned vessels, spotter aircraft, and processing plants. An active baitfish fishery along the Atlantic and Gulf coasts harvests about $5 \%$ of the amount landed by the industrial fishery. These fisheries are managed by individual states through the Atlantic States Marine Fisheries Commission (ASMFC) and the Gulf States Marine Fisheries Commission (GSMFC).
Atlantic menhaden are found from Nova Scotia, Canada, to West Palm Beach, Fla. As coastal waters warm in April and May, large surface schools form along the coasts of Florida, Georgia, and the Carolinas. The schools move slowly northward, stratifying by age and size during the summer, with the older and larger fish generally moving farther north. The southern migration begins in early fall with surface schools disappearing in late December or early January off the Carolinas. Atlantic menhaden may live 10 years, but most fish caught are 3 years of age or younger.

Menhaden landings rose during the 1940 's and early 1950's and peaked at
$712,100 \mathrm{t}$ in 1956. Landings remained high during the late 1950's and early 1960's, dropped precipitously during the middle 1960's, and remained low, bottoming out at $161,600 \mathrm{t}$ in 1969 (Fig. 10-1). Since 1970 , landings have improved but not to the levels of the late 1950 's. A recent peak of 418,600 toccurred in 1983 , even though recruitment to age 1 is comparable with the 1950 's. The commercial value of Atlantic menhaden for $1985-89$ averaged $\$ 31.9$ million/year.

In 1990, just a few menhaden "reduction," or processing, plants were in operation, located in Beaufort, N.C.; Reedville, Va.; coastal Maine (one Russian factory

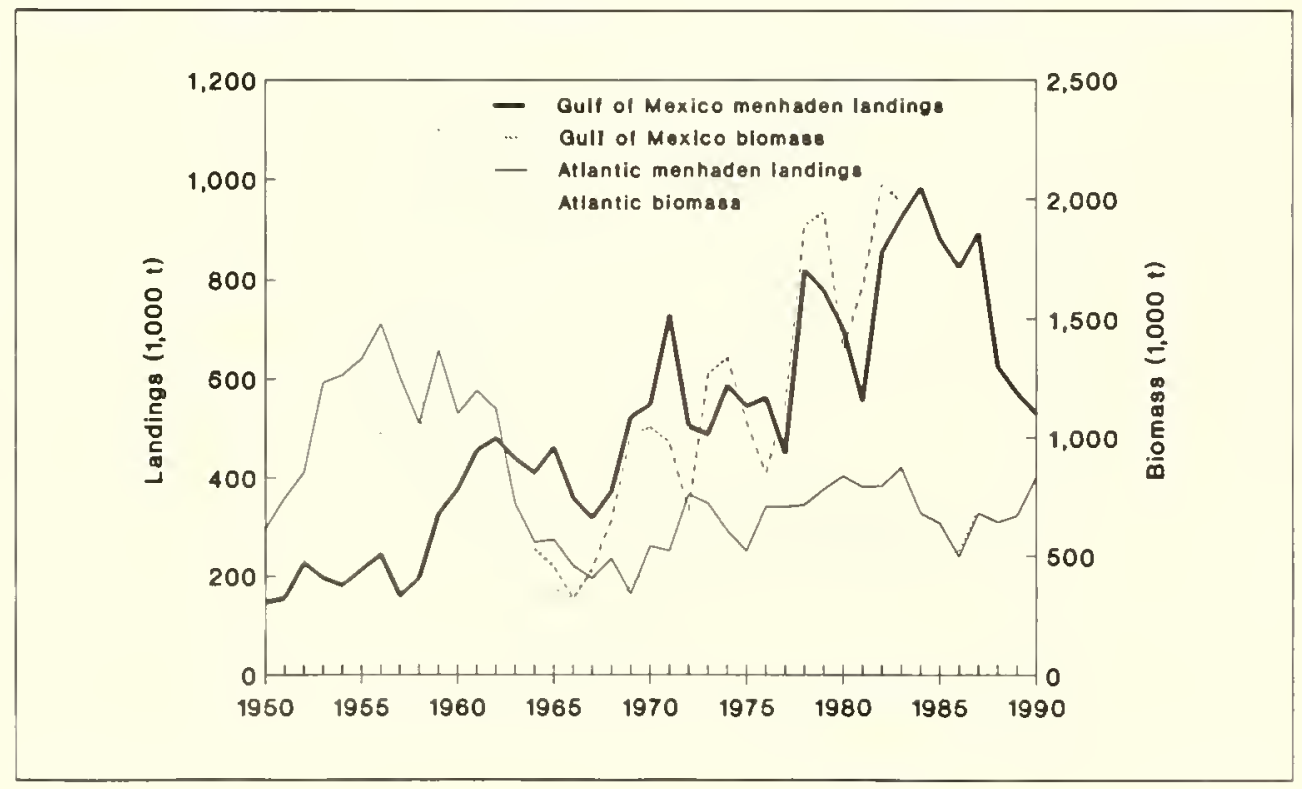




\section{.. Atlantic Menhaden}

ship as part of an internal-waters processing agreement); and New Brunswick, Can.

The stock collapse in the 1960's drove fishing effort southward to North Carolina and Virginia where menhaden are generally younger and smaller than those in the north. Overutilization owing to "growth overfishing" (catching too many fish be- fore they grow to full size) has been a prime management concern for this stock, but spawning stock size also has remained low since 1962. A management plan written in 1982 by the ASMFC was not adopted by all states, and the Commission is rewriting it.

Landings were generally high during the middle 1980's (greater than 800,000 t for $1982-87$ ), but they have declined steeply from 894,200 t to 528,300 t between 1987 and 1990. The commercial value of Gulf menhaden for 198589 averaged $\$ 66.2$ million/year.

Because this species is short lived and has a high natural mortality, "growth overfishing" has not been a major concern. Estimates of maximum spawning potential have generally been high (over $30 \%$ ). Management coordinated through the GSMFC consists of a 6-month fishing season (midApril through mid-October) and closure of inside waters across the northern Gulf of Mexico.

\section{Butterfish}

Table 10-1.- Recent average, current potential, and long-term potential yields in metric tons (t), and status of utilization of southeastern menhaden and butterfish. The LTPY, CPY, and RAY for the unit equals the sum of the species' LTPY'S, CPY's, and RAY's.
A small purse-seine fishery for butterfish is developing in the Gulf of Mexico. The potential for this fishery is significant (over $30,000 \mathrm{t}$ ), but the annual yield peaked in
1988 at $4,800 \mathrm{t}$, and the average annual yield for 1986-90 (minus 1988) was just $570 \mathrm{t}$ (Table 10-1). $\begin{array}{lr}\text { Long-term potential yield (LTPY) }= & 1,177,000 \mathrm{t} \\ \text { Current potential yield (CPY) }= & 957,000 \mathrm{t} \\ \text { Recent average yield (RAY) }{ }^{1}= & 922,000 \mathrm{t}\end{array}$

\begin{tabular}{|c|c|c|c|c|}
\hline \multirow[b]{2}{*}{ Species and area } & \multicolumn{3}{|c|}{ Yield $(\mathrm{t})$} & \multirow{2}{*}{$\begin{array}{l}\text { Status of } \\
\text { utilization }\end{array}$} \\
\hline & RAY ${ }^{\prime}$ & CPY & LTPY & \\
\hline \multicolumn{5}{|l|}{ Menhaden } \\
\hline Gulf of Mexico & 575,000 & 575,000 & 660,000 & Full \\
\hline Atlantic & 345,000 & 345,000 & 480,000 & Over \\
\hline Gulf butterfish & 2,000 & 37,000 & 37,000 & Under \\
\hline
\end{tabular}

198890 average 
ISSUES
Growth overfishing is an important issue. The demand to harvest menhaden as soon as they become available reduces the opportunity for greater weight production. In addition, interstate coordination of menha- den management is needed because of the migratory nature of the fish. The importance of menhaden as prey for other species also needs to be considered. 


\section{INTRODUCTION}

Important U.S. southeast/Caribbean marine invertebrates include various shrimps, spiny lobster, stone crab, conchs, and corals (Table 11-1). The fisheries range from almost nil for certain corals to extensive and valuable for the Gulf shrimps. Though many fisheries, such as spiny lobsters and stone crabs, have only moderate value nationally, they are important to local economies. Owing to the great differences in yield, value, management, harvest techniques, fishery area, etc., for these fisheries, each species group must be examined separately to gain a realistic perspective of their status.

\begin{abstract}
Table 11-1.-Recent average, current potential, and long-term potential yields in metric tons $(t)$, and status of utilization of southeast and Caribbean invertebrate species. The LTPY, CPY, and RAY for the unit equals the sum of the species' LTPY's, CPY'S, and RAY's. Where the species' LTPY is unknown, the species' CPY is substituted in the sum. If the species' CPY is unknown, the species' RAY is substituted.
\end{abstract}

$\begin{array}{ll}\text { Long-term potential yield (LTPY) }= & 126,632 \mathrm{t} \\ \text { Current potential yield }(C P Y)= & 120,025 \mathrm{t} \\ \text { Recent average yield }(\text { RAY })^{\prime}= & 120,585 \mathrm{t}\end{array}$

$\begin{array}{ll}\text { Recent average yield }(\text { RAY })^{\prime}= & 120,025 t\end{array}$

\begin{tabular}{|c|c|c|c|c|}
\hline \multirow[b]{2}{*}{ Species and area } & \multicolumn{3}{|c|}{ Yield $(t)$} & \multirow{2}{*}{$\begin{array}{l}\text { Status of } \\
\text { utilization }\end{array}$} \\
\hline & RAY' & CPY & LTPY & \\
\hline
\end{tabular}

$\begin{array}{lr}\text { Shrimp } & \\ \text { Brown } & \\ \text { Gulf of Mexico } & 67,906 \\ \text { Atlantic } & 3,892 \\ \text { White } & \\ \text { Gulf of Mexico } & 29,319 \\ \text { Atlantic } & 5,045 \\ \text { Pink } & \\ \text { Gulf of Mexico } & 6,049 \\ \text { Atlantic } & 1,207 \\ \text { Royal red } & 320 \\ \text { Seabob } & 2,180 \\ \text { Rock } & 49 \\ \text { Spinylobsters } & \\ \text { Southeast U.S. } & \\ \text { Caribbean } & 2,960 \\ \text { Stone crab } & \\ \text { Queen conch } & \end{array}$

198890 average.

${ }^{2}$ Long-term potential of brown, white, and pınk shrımp based upon largest observed 10-year average annual yiekd

${ }^{3}$ Yields based upon commercial catches; recreational catch is unknown but may be significant.

4rields are in tons of claws; declawed crabs regenerate new claws.

${ }^{5}$ Fishing prohibited in Florida and U.S Virgin islands.

${ }^{6}$ Coral harvests prohıbited except for a small take allowed for use in aquarium and pharmaceutıcal industries.

\section{SPECIES AND STATUS}

\section{shrimp}

Brown, white, and pink shrimps account for $89 \%$ of the total Gulf of Mexico shrimp catch. In 1990 alone, these three important species produced $111,702 \mathrm{t}$ valued at over $\$ 405$ million (Fig. 11-1). They are found in all U.S. Gulf waters inside 60 fathoms $(\mathrm{fm})$. Most of the offshore brown shrimp catch is taken at $11-20 \mathrm{fm}$ depths, white shrimp are caught in $5 \mathrm{fm}$ or less, and pink shrimp in $11-15 \mathrm{fm}$. Brown shrimp is most abundant off the Texas/Louisiana coast; the greatest concentration of pink shrimp is found off southwest Florida. Current, recent, and long-term potential yields for these species are given in Table 11-1.

These shrimps have been fished commercially since the late 1800 's, at first with long seines in shallow water. However, the otter trawl, introduced in 1915, extended shrimping to deeper waters. At first, most vessels towed one large trawl, sometimes 120 feet wide at the mouth. Soon, a double trawl arrangement (each about 40-75 feet wide at the mouth) was found more effective. Some shrimpers began using a twin trawl system, towing four trawls, each 
Figure 11-1.-U.S. shrimp landings from the Gulf of Mexico, 1960-90, and the parent stock abundance indices for brown, white, and pink shrimp.

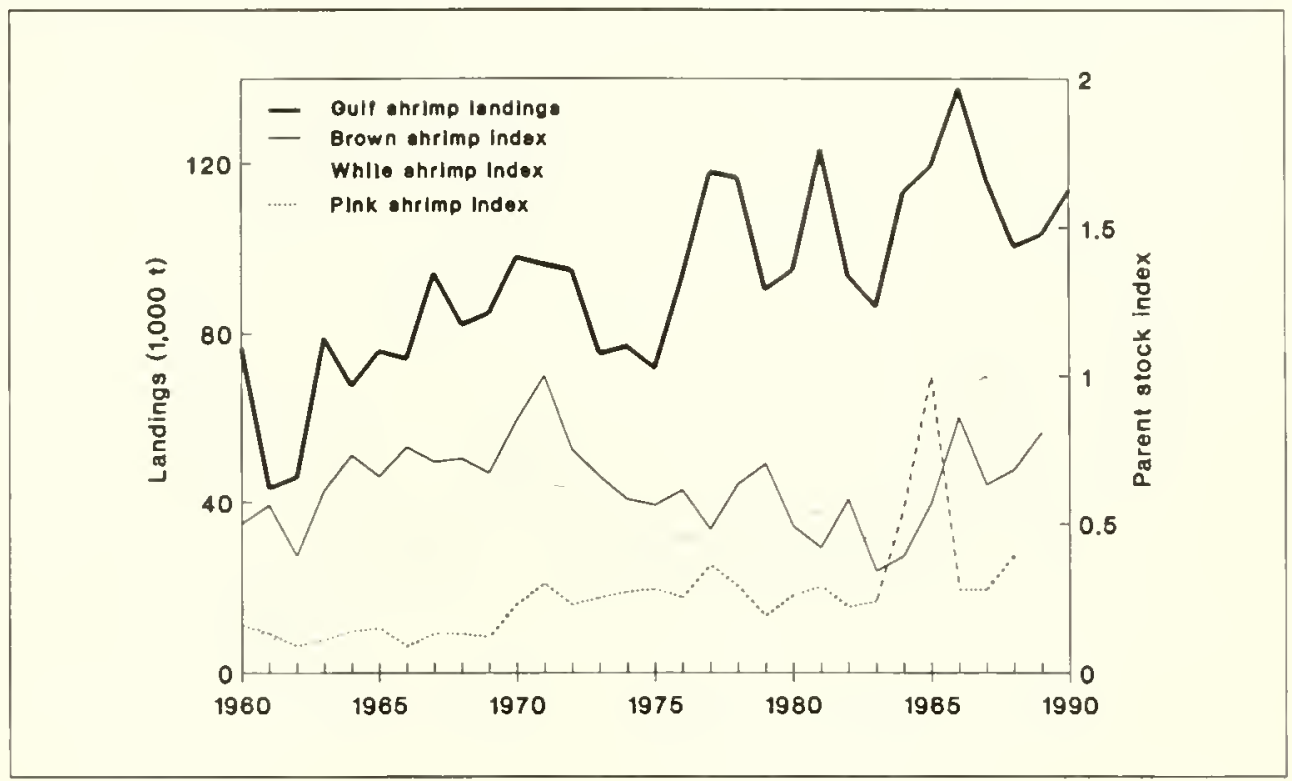

about 40 feet wide at the mouth, at one time. Widely accepted, this design is now the most common gear on commercial offshore shrimpers.

Gulf brown and white shrimp catch levels have increased significantly over the past 30 years, while pink shrimp catches, stable until about 1985, have declined in recent seasons and are now at an all-time low. Numbers of young shrimp for each species entering the fisheries have generally re flected catch levels. The commercial shrimp are harvested at maximum levels. The fishery is believed to have more boats and gear than needed, i.e., reducing fishing effort would not significantly reduce the shrimp catch. But reducing bycatch would help protect finfish.

The Gulf of Mexico Shrimp Fishery Management Plan regulations restrict shrimping with closures on two shrimping grounds (the "Texas closure" for brown shrimp and a pink shrimp closure off Florida) and with size limits on white shrimp caught in Federal offshore waters that are landed in Louisiana. These regulations strive to improve the monetary value of the fishery.

The number of young brown shrimp produced per parent has increased significantly, but not for white and pink shrimp. The brown shrimp increase appears related to marsh alterations. Coastal sinking and a sea-level rise in the northwestern Gulf inundates intertidal marshes longer, allowing the shrimp to feed for longer periods within the marsh area. In the Gulf, both factors have also expanded estuarine areas, created more marsh edges, and provided more protection from predators. As a result, the nursery function of those marshes has been greatly magnified and brown shrimp production has expanded. However, continued subsidence will lead to marsh deterioration and an ultimate loss of supporting wetlands, and current high fishery yields may not be indefinitely sustainable.

\section{Spiny Lobster}

Annual Florida spiny lobster landings were fairly stable during the 1980 's, running about 2,700 t from the Gulf of Mexico, but yielding record landings in 1989 of 3,200 $t$, valued at about $\$ 20$ million. On Florida's Atlantic coast, landings have averaged 230 $t$, valued at $\$ 2$ million. The fishery is considered "overcapitalized," with about 500,000 lobster traps in use. Half that number of traps would provide the same catch. Fishermen use live undersized lobster to bait traps, but owing to a high mortality rate 
... spiny Lobster for these baits, about $30-50 \%$ of the potential yield is lost. The recreational fishery is large at the beginning of the season, but its total harvest level is unknown.

Spiny lobster larvae may drift at sea for nine months, and thus identification of their source or parent stock is almost impossible; however we need to know far more about their origins and movements to improve our management of them. Currently, the species is managed under a joint FMP, coordinated with Florida regulations which specify a 3-inch minimum carapace length, a closed season from 31 April to 5 August, protection of egg-bearing fernales, closure of some nursery areas, recreational bag limits, and a controversial twoday "sport" season.
Caribbean spiny lobsters are caught primarily by fish traps, lobster traps, and divers. The Caribbean Council's Spiny Lobster FMP includes the Federal waters of Puerto Rico and the U.S. Virgin Islands and is based on a 3.5-inch minimum carapace length and protection of young egg-bearing lobsters.

Annual spiny lobster landings for Puerto Rico have averaged 144 tover the past 23 years, varying from $108 \mathrm{t}$ in 1972 to a high of $233 \mathrm{t}$ in 1979, then declining to a low of $65 \mathrm{t}$ in 1988. No precise data are available on fishing effort, but the Puerto Rican stock may be overutilized. U.S. Virgin Islands landings for $1980-88$ were fairly stable, averaging $19 \mathrm{t}$.

\section{Stone Crab}

Stone crabs are caught mainly in southern Florida, though some are landed further north along Florida's west coast. The Gulf of Mexico Stone Crab FMP, approved in September 1979, generally extended Florida's regulations into the EEZ. These regulations are based on a minimum claw size of 2.75 inches, biodegradable trap panels, protection of egg-bearing females, and closed seasons. Minimum size regulations assure that crabs have reproduced at least once before being caught.

Annual catches (claw weight) varied from 1,200 to $1,400 t$ in the Gulf of Mexico through the 1980's and recent annual val- ues average $\$ 12-15$ million. Atlantic coast landings average around $34 \mathrm{t}$, worth $\$ 120,000$. The number of crab traps set increased from 295,000 in $1979-80$ to 567,000 in 1984-85 but have been relatively stable in recent years, though estimated seasonal trap hauls (fishing effort) increased from 3.6 million in 1985 to 4.8 million in 1987. Thus, more of the total landings were harvested earlier and this shortened the effective fishing season length. However, it is unlikely that recent maximum production figures can be sustained on a long-term basis.

\section{Conch and Coral}

Conchs (primarily the queen conch but other species too) are mostly taken by divers and can be easily depleted. They are currently protected in state and Federal waters off Florida and in the territorial waters of the U.S. Virgin Islands; meanwhile an FMP is being developed for the Federal waters off Puerto Rico and the U.S. Virgin Islands.

Corals are managed as two groups: Hard and soft corals. Hard corals are currently protected (except for very small collections taken by permit for research and educational purposes) because they are generally slow growing and provide critical habitat for many fishes. In fact, their value as habitat is considered far more important than their commercial value.

Soft corals include gorgonians and sea fans. Some gorgonians are taken (about 50,000 colonies per year) for the aquarium and pharmaceutical industries. Growth potential for most species is considered limited. Sea fans are completely protected except via permit for research and educational use. 
ISSUES

Habitat
Estuarine habitat conditions affect all shrimp fisheries. Specifically, marsh losses remove critical habitat for young shrimp and thereby depress shrimp production. Studies are needed on losses of shrimp nursery habitats, environmental changes, predator abundance, and pollution. Florida spiny lobsters depend on good reef habitat and shallow-water algal flats for feeding and reproduction, but this need may conflict with development. Habitat is very im- portant to stone crab survival, particularly management of water quality and water flow through the Everglades. Specific water requirements need to be identified and maintained. Also needed is a unified program to integrate and study the effects of environmental alterations, fishing technology, regulations, and economic factors on shrimp, lobster, and crab production and restoration. Steps need to be taken to mitigate or restore lost habitat.

\section{stock origin}

Spiny lobster parent stock could be of pan-Caribbean origin, or it could be composed of a number of different spawning stocks. The sources of all Florida and Car- ibbean lobster stock production (both U.S. and foreign landings) need to be identified and international management established to prevent overutilization.

\section{Growth Overfishing}

Many small spiny lobsters are caught in the Puerto Rican fishery. If these lobsters were allowed to grow to a larger size before harvest, there would be a substantial increase in yield. Modification of the traps to allow more of the small lobsters to escape and implementation of a minimum size rule need to be investigated.

Many small shrimps are caught in the Puerto Rican fishery. Models have shown that there would be a substantial increase in value to the fishery if these shrimps were allowed to grow to a larger size before harvesting and if the current price structure did not change to reflect the change in landings by size category. Modifications in shrimp management to reduce the capture of small shrimp, without causing a shift in price per pound, in certain size categories need to be investigated.

\section{Gear Conflict}

A continuing gear conflict between stone crab trappers and shrimp trawlers off southwestern Florida has been mostly resolved in the EEZ with a line separating the fisheries areas and seasonal closure areas. This approach needs continued monitoring to gauge its success and prevent renewal of the conflict. 


\section{INTRODUCTION}

Salmon are fished commercially and recreationally in Puget Sound, Oregon and Washington coastal rivers, the Columbia River, California's Klamath River, and in the ocean off the three states. These species have long been harvested-indeed since time immemorial by many Indian tribes. And today, west coast salmon management is very complex, involving the U.S.-Canada Pacific Salmon Commission (PSC), state fishery agencies, Indian tribes, and the Pacific Fishery Management Council (PFMC).

\section{SPECIES AND STATUS}

Figure 12-1.-Recreational and commercial chinook salmon landings (thousands of fish) in Oregon, Washington, and California, 1960-90.
Five species of Pacific salmon are caught in the coastal fisheries of Washington, Oregon, and California: Chinook, coho, sockeye, pink, and chum. Pacific salmon spend their adult life ( $1-7$ years) at sea and return to freshwater streams to spawn. From their freshwater spawning grounds, the young salmon may migrate thousands of miles out to sea and into international waters beyond the 200-mile U.S. Exclusive Economic Zone (EEZ).

Some Pacific coast salmon catches during 1960-90 fluctuated widely (Fig. 12-1, $12-2,12-3)$, largely due to varied survival rates. For example, El Niño, an unusual warm ocean condition, devastated chinook and coho salmon in 1983-85, and both species have had poor survival in recent years.

Commercial salmon landings have lately been valued at about $\$ 140$ million at dockside. If sport-caught fish were valued at $\$ 20.00$ each (a conservative figure to many economists), the average recreational catch for 1987-90 would be worth over \$24 million. Some economists think a substantially higher value per fish would be more realistic.

Stocks and harvests of some salmon species can be improved (Table 12-1). Though pink, chum, and sockeye salmon catches probably will not change much from recent yearly averages, better coho survival could help them approach their long-term average production. After excellent survival rates and returns in 1988, chinook production has dropped dramatically, and reduced returns and catches are expected this year (1991).

Several agencies hope to double production of certain chinook stocks. Still, for all five species of salmon, there is more fishing gear than needed to harvest them, and strict limitations are required to protect the stocks. Thus, all species are listed as overutilized.

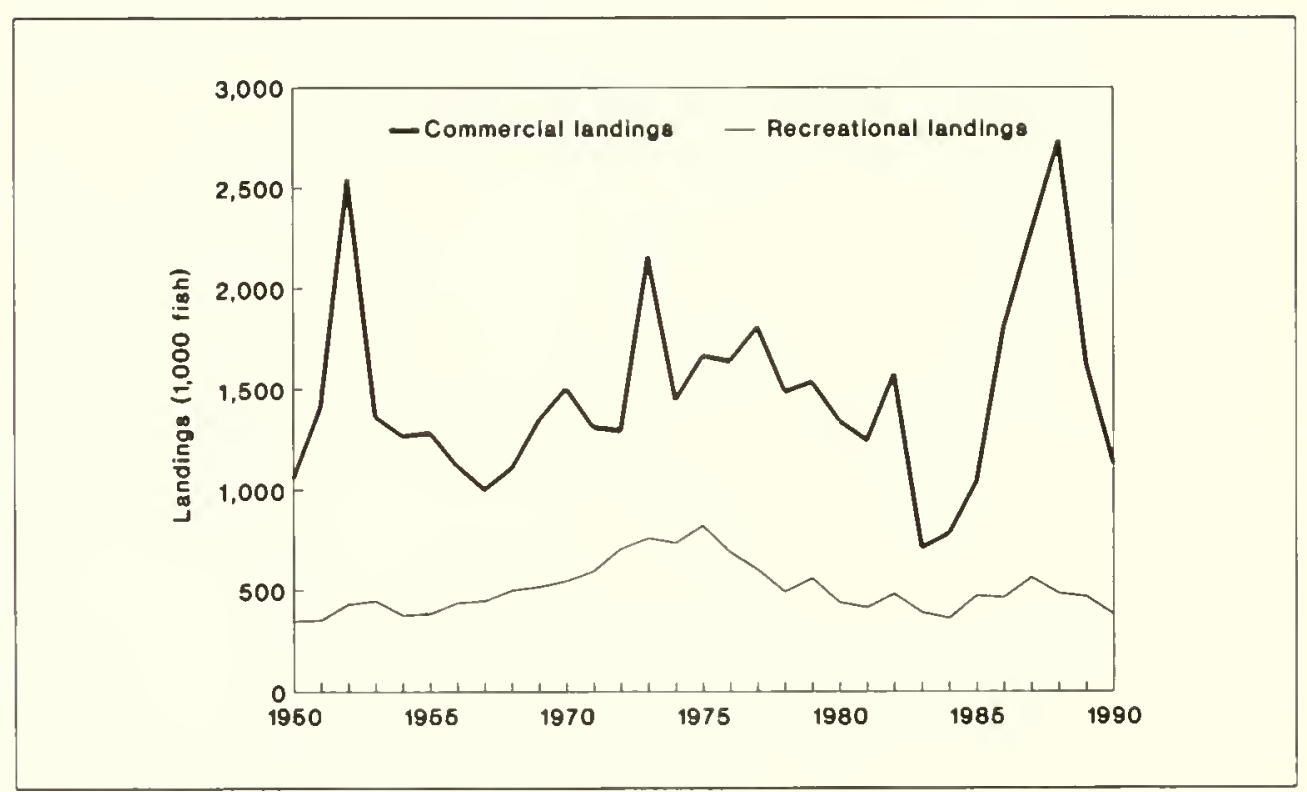


Figure 12-2.-Recreational and commercial coho salmon landings (thousands of fish) in oregon, Washington, and California, 1960-90.
Figure 12-3.-Combined commercial and recreational landings of pink, sockeye, and chum salmon landings (thousands of fish) in Oregon, Washington, and California, 1960-90.
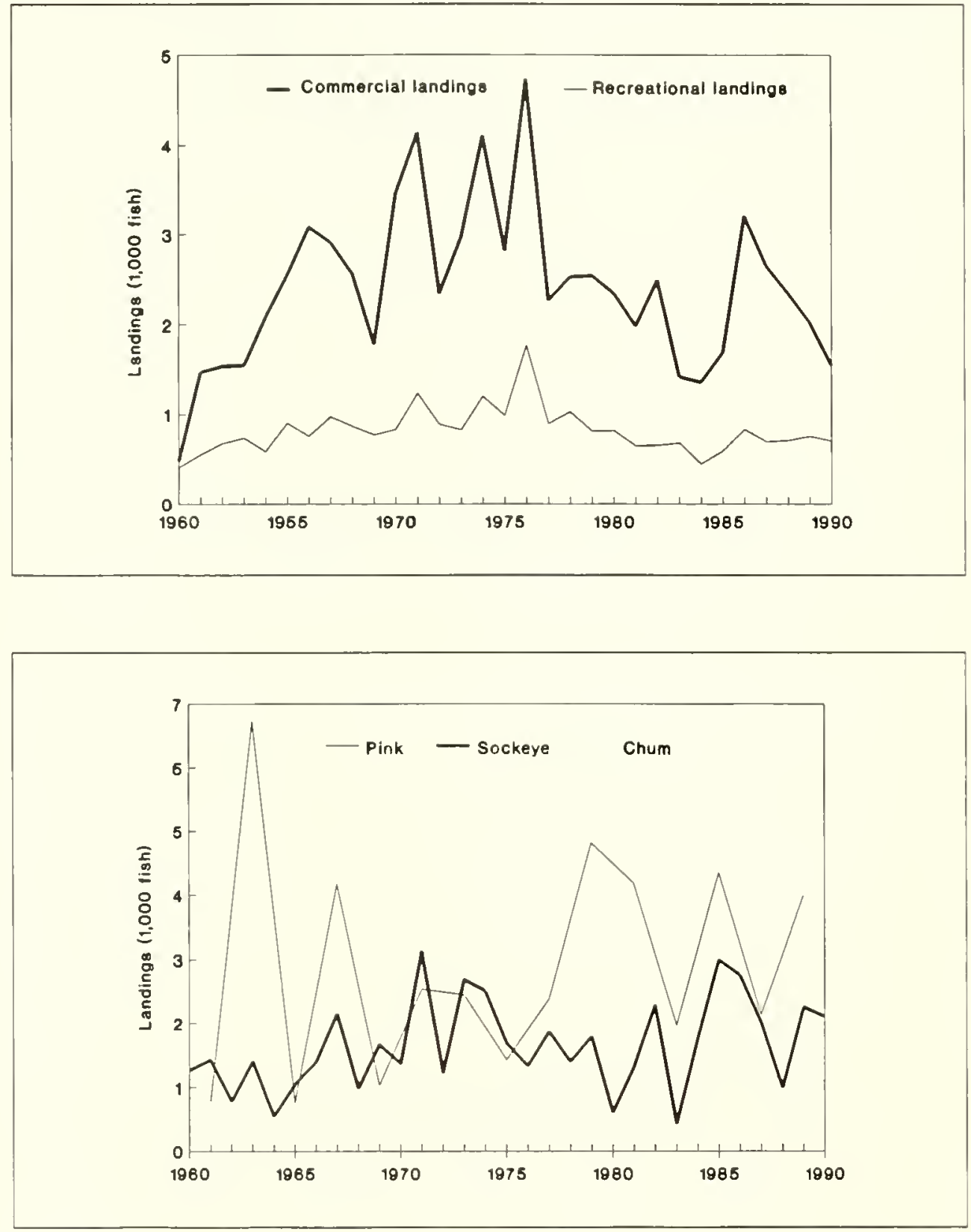

Table 12-1.-Recent average, current potential, and long-term potential yields of salmon in the Pacific coast fishery in numbers of salmon. The LTPY, CPY, and RAY for the unit equals the sum of the species' LTPY'S, CPY's, and RAY's.
Long-term potential yield (LTPY) $=11,806,000$

Current potential yield $(C P Y)=\quad 11,806,000$

Recent average yield $(\text { RAY })^{\prime}=\quad 11,268,000$

\begin{tabular}{lcccc}
\hline & \multicolumn{3}{c}{ Yield (no. of salmon) } & $\begin{array}{c}\text { Status of } \\
\text { utilization }\end{array}$ \\
\cline { 2 - 4 } Species & RAY & CPY & LTPY & Over \\
Chinook & $2,274,000$ & $2,274,000$ & $2,274,000^{2}$ & Over \\
Coho & $2,693,000$ & $3,231,000$ & $3,231,000$ & Over \\
Pink & $3,496,000$ & $3,496,000$ & $3,496,000$ & Over \\
Sockeye & $1,788,000$ & $1,788,000$ & $1,788,000$ & Over \\
Chum & $1,017,000$ & $1,017,000$ & $1,017,000$ & \\
\hline
\end{tabular}

'Average is for 1988-90 except for pink, which is a 1985-87-89 average

${ }^{2}$ Long term goals for some stocks include doubling of production, primarily through large scale improvements in freshwater habitat If successful, this would diamalically increase LTPY. 


\section{Chinook and \\ coho salmon}

Ocean fisheries for these species are managed by the PFMC. The decline in the ocean coho catch during the past 20 years, particularly off Washington, is largely due to a shift in catch to "inside fisheries," like Puget Sound, in compliance with a Federal court ruling in the early 1970's that Washington treaty Indians are entitled to up to $50 \%$ of the catch of salmon migrating through their usual and accustomed tribal fishing areas.

Most ocean chinook are caught by the commercial troll fishery, whereas an increasing share of the ocean catch of coho is being allocated to sport fishermen. Annual catch quotas now limit the entire coho catch off Washington, Oregon, and California, and the chinook catch off Washington and Oregon (north of Cape Falcon). In 1990, there were 4,550 troll boats licensed to fish commercially off these three states. For the sport fishery, about 600 charter boats were licensed and 657,000 anglertrips or days were made.

\section{sockeye, Pink, and chum salmon}

\section{ISSUES}

Freshwater Habitat
Management of these three species rests primarily with the PSC and state and tribal fishery agencies. Washington catches of sockeye and pink salmon are composed largely of fish migrating to Canada's Fraser River. Although recent Fraser River salmon

Worsening freshwater (spawning) habitat has been the main cause of the salmon decline. This includes siltation problems and, particularly, the lack of water for spawning and fish passage. For example, serious fish passage problerns at Columbia River hydroelectric dams have been a major factor in salmon declines. In California, the conflict is primarily between fish needs for water and farm irrigation demands.

Owing to habitat losses, the Sacramento runs have been extremely large, their U.S. catch is limited under the U.S.-Canada Salmon Treaty of 1985. U.S. stocks of pink, sockeye, and chum salmon, although limited in range and size, appear to be fairly stable.

winter-run chinook was listed as threatened under the Endangered Species Act (ESA) in 1990. In April 1991, the NMFS recommended that a Snake River sockeye stock be listed as endangered under the ESA. Requests have also been received to list spring, summer, and fall chinook stocks from the Snake River owing to their poor condition. Wild coho stocks of the lower Columbia River were recently declared extinct by the NMFS. wild vs. Hatchery stocks Increased production by salmon hatcheries, particularly of chinook and coho, has raised concerns about the relationship between natural (wild) and hatchery-produced fish. Though hatchery fish can supplement natural production, they also may compete with or even replace wild salmon. This potential problem must be addressed when trying to increase depressed wild salmon runs.

\section{Treaty Conflicts}

Conflicts between treaty Indian and non-Indian fishermen sometimes arise. Lack of agreement over Indian catch allowances in California's Klamath River made the setting of 1991 ocean salmon fishing regula- tions by the PFMC a challenge. In Washington, a Federal court ruling that salmon must be managed to protect the smallest or the weakest stock has curtailed ocean catches in recent years.

\section{Incidental catch}

Some salmon, mainly chinook, are accidentally caught at sea in the Pacific whiting fishery. Though the number taken is small compared with catches in other fisheries, this incidental catch becomes a politically sensitive issue when ocean fisheries are severely restricted, as in 1991 when troll fishing was prohibited in certain coastal areas. 


\section{INTRODUCTION}

Table 13-1.-Average annual number of Alaska salmon caught by decade since 1880 . Source: ADF\&G data.
Alaska's Pacific salmon fisheries contribute to the world's food supply, the economy and health of the Nation, and rank as the state's largest nongovernmental employer. They also provide recreational opportunities and are an integral part of Alaska's native culture and heritage.

Pacific salmon spend a portion of their life (1-7 years) at sea and return to freshwater streams to spawn and die. From their freshwater spawning grounds, the young salmon may migrate thousands of miles out to sea and into international waters outside of the U.S. Exclusive Economic Zone (EEZ).

The U.S. Alaska salmon industry began with purchase of the territory from Russia in 1867. Catch levels have varied widely since then (Table 13-1). By 1896, the Alaska salmon catch reached 11.5 million fish and increased to 126 million by 1936 . Catches declined after 1941 to a low of 22 million in 1974. In the 1980's, catches increased, hitting an all-time high in 1989 of 155 million salmon (Table 13-1, Fig. 13-1). Sport catches of salmon in 1988 totaled about 908,000 fish in all waters.

The value of the 1990 state-wide catch $(305,123 t)$ has been estimated at $\$ 540$ million. Though the 1990 catch was smaller than the $322,528 \mathrm{t}$ taken in 1989 , it was worth more because of its larger valuable sockeye harvest.

Alaska's 34,000 -mile coast is nearly twothirds the length of the coastline of the "lower 48 " states. Salmon management in such a vast area requires a complex mixture of domestic and international bodies, treaties, regulations, and agreements. Federal and state agencies participate in the North Pacific Fisheries Management Council (NPFMC). Salmon management is also negotiated with Canada in the Pacific Salmon Commission, with Canada and Japan in the International North Pacific Fisheries Commission (INPFC), and via bilateral and multilateral talks and negotiations with Taiwan and the Republic of Korea.

Management in the EEZ (3-200 miles offshore) is the responsibility of the NMFS and the NPFMC. The Council leaves to the INPFC the management of foreign salmon fisheries in the EEZ west of long. $175^{\circ} \mathrm{E}$. The Alaska Department of Fish and Game (ADFEG) manages all fisheries in state waters.

\begin{tabular}{cccc} 
Period & Average annuai catch & \multicolumn{1}{c}{ Period } & Average annual catch \\
\hline $1880-89$ & $1,582,000$ & $1940-49$ & $77,884,000$ \\
$1890-99$ & $9,461,000$ & $1950-59$ & $41,440,000$ \\
$1900-09$ & $30,967,000$ & $1960-69$ & $50,894,000$ \\
$1910-19$ & $63,946,000$ & $1970-79$ & $48,458,000$ \\
$1920-29$ & $70,237,000$ & $1980-89$ & $121,950,000$ \\
$1930-39$ & $90,064,000$ & 1990 & $153,000,000$
\end{tabular}

\section{SPECIES AND STATUS}

Alaska's five salmon species (chinook, coho, chum, sockeye, and pink) are fully utilized, and stocks generally have rebuilt to or beyond previous high levels (Table 13-2). Some stocks, like chinook and coho, may be harmed by foreign high-seas catches. High-seas catch data are incomplete and more research is needed so salmon of American and Asian origin can be identified and protected.
Some salmon may be regionally overutilized. In Bristol Bay, chinook catches are far below recent averages-the 1990 catch was the second smallest of the 1950-90 period. In the lower Yukon area, chinook catches are about $21 \%$ below par. Meanwhile pink salmon in Bristol Bay are far below 1970-89 harvests, and wild sockeye and chum salmon in Prince William Sound have declined. 


\section{Alaska Salmon Fisheries}

60

Figure 13-1.-Alaska salmon landings, 1970-90.

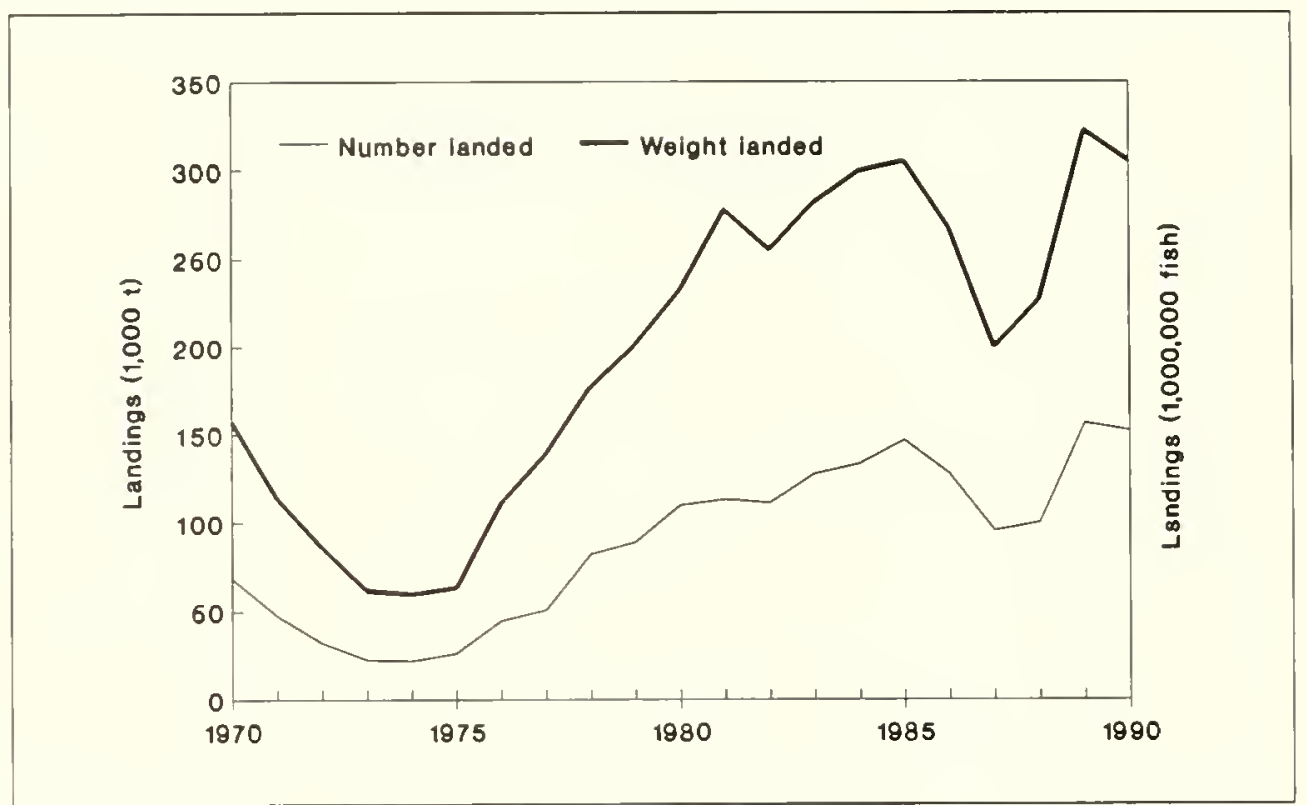

Table 13-2.-Recent average, current potential, and long-term potential yields in metric tons (t), and status of utilization of Alaska salmon. The LTPY, CPY, and RAY for the unit equals the sum of the species' LTPY's, CPY's, and RAY's.

$\begin{array}{lr}\text { Long-term potential yield (LTPY) }= & 273.719 t \\ \text { Current potential yield (CPY) }= & 273.719 t \\ \text { Recent average yield }(\text { RAY })^{\prime}= & 288.1333 t\end{array}$

\begin{tabular}{|c|c|c|c|c|}
\hline \multirow[b]{2}{*}{ Species } & \multicolumn{3}{|c|}{ Yield (t) } & \multirow{2}{*}{$\begin{array}{l}\text { Status of } \\
\text { utilization }\end{array}$} \\
\hline & RAY' & CPY & LTPY & \\
\hline Pink & 118,232 & 109,972 & 109,972 & Full \\
\hline Sockeye & 114,481 & 103,661 & 103,661 & Full \\
\hline Chum & 36,547 & 38,900 & 38,900 & Full \\
\hline Coho & 14,162 & 15,372 & 15,372 & Full \\
\hline Chinook & 4,711 & 5,814 & 5,814 & Full \\
\hline
\end{tabular}

'1988-1990 average.

\section{ISSUES}

Three important problems facing Alaska salmon are: 1) Interceptions by high-seas foreign driftnet fisheries; 2) accidental chinook catches by the U.S. groundfish fishery; and 3) destruction of spawning and rearing habitats.

\section{Driftnet Fisheries}

High seas (pelagic) driftnet fishing has long been a contentious issue in the North Pacific Ocean and the Bering Sea. Japan still runs mothership salmon driftnet and land-based salmon driftnet fisheries. About 174.000 North American salmon were caught by the Japanese mothership fishery in 1990.

The high-seas squid driftnet fisheries of
Japan, Korea, and Taiwan are suspected of taking large numbers of North American salmon. Over 1,000 vessels fish an area of the North Pacific Ocean larger than our contiguous 48 states. Some of the vessels set 40 miles of gill net a night. Protecting salmon from these fisheries is hampered by a lack of information. 
Chinook Bycatch
Chinook catches by U.S. groundfish trawlers in the Bering Sea and the Gulf of Alaska are another problem. About 15,000 chinook were taken in the trawl fishery in each area in 1990. In addition, early data from the Bering Sea's "Donut Hole" area suggest that the bycatch might exceed
60,000 chinook. Concern grew in 1991 when, by early February, over 20,000 chinook were estimated to have been caught in the Bering-Aleutian area and about 2,200 chinook were taken in the Gulf of Alaska.

\section{Habitat Problems}

Logging and industrial and urban development can often degrade salmon habitat. Logging problems can include road construction and maintenance, use of chemicals, and timber harvest. Though large areas of Alaska's wetlands are presently undisturbed and pristine and provide critical salmon habitat, logging activities have affected about 100,000 acres of stream- side habitat and 3,000 miles of streams. From 1981 to 1988 , development was allowed on about 41,000 acres of wetlands. The State of Alaska has currently not accepted the Environmental Protection Agency's policy on "no net loss" of wetlands. Very little information is yet available on the value of these vast wetlands as fish habitat. 


\section{INTRODUCTION}

Several pelagic species provide important fisheries for food, bait, and industrial fishery products. One, the Pacific sardine, was fished to the point of collapse and only now begins to show signs of improvement (Table 14-1).
Table 14-1.-Recent average, current potential, and long-term potential yields in metric tons $(t)$, and status of utilization of Pacific coast and Alaska pelagic species. The LTPY, CPY, and RAY for the unit equals the sum of the species' LTPY's, CPY's, and RAY's. Where the species' LTPY is unknown, the species' CPY is substituted in the sum. $\begin{array}{ll}\text { Long-term potential yield (LTPY) }= & 614,100 \mathrm{t} \\ \text { Current potential yield }(\text { CPY })= & 231,100 \mathrm{t} \\ \text { Recent average yield }(\text { RAY })^{\prime}= & 120,400 \mathrm{t}\end{array}$

\begin{tabular}{|c|c|c|c|c|}
\hline \multirow[b]{2}{*}{ Species and area } & \multicolumn{3}{|c|}{ Yield (t) } & \multirow{2}{*}{$\begin{array}{l}\text { Status of } \\
\text { utilization }\end{array}$} \\
\hline & RAY $^{1}$ & CPY & LTPY & \\
\hline Northern anchow & $60,000^{2}$ & 166,000 & 219.000 & Under \\
\hline Pacific sardine & $4,200^{3}$ & 10,000 & 250.000 & Recovering \\
\hline Jack mackerel & $14,200^{4}$ & 10,000 & 100,000 & Under \\
\hline \multicolumn{5}{|l|}{ Pacific herring } \\
\hline Gulf of Alaska & 18,200 & 28,200 & Unknown & Full \\
\hline \multicolumn{5}{|l|}{ Pacific herring } \\
\hline Bering Sea & 23,800 & 16,900 & Unknown & Full \\
\hline
\end{tabular}

'1988-90 average

${ }^{2}$ U 5 yield $=7,000 \mathrm{~L}$, Mexican yield $=53,000 \mathrm{~L}$.

${ }^{3} 198889$ average.

${ }^{4} 1981-89$ average

\section{SPECIES AND STATUS}

Northern anchovy, Pacific sardine, jack mackerel, and Pacific herring are important fisheries off the Pacific coast and Alaska. The northern anchovy, Pacific sardine, and jack mackerel are harvested by purse seiners off southern California and Baja California, Mexico. U.S. anchovy fisheries are managed under the Northern Anchovy Fishery Management Plan (FMP), while Pacific sardine and jack mackerel are managed by the State of California. All three species will be managed by the
Coastal Pelagics FMP now being developed.

Pacific herrings are taken as bycatch in the groundfish fisheries in the Gulf of Alaska and the Bering Sea. Under groundfish FMP's for those two areas, the Pacific herring is a prohibited species and cannot be landed by groundfish fishermen. Large commercial herring fisheries also exist in Alaska coastal areas, but they are managed by the State of Alaska.

\section{Northern Anchovy}

Northern anchovies are small, short-lived plankton eaters and typically school near the surface in waters of $54^{\circ}-71^{\circ} \mathrm{F}\left(12^{\circ}\right.$ $21.5^{\circ} \mathrm{C}$ ). They rarely exceed 4 years of age and 7 inches total length. The species ranges from the Queen Charlotte Islands, B.C., to Magdalena Bay, Baja Calif. The "central subpopulation," which supports U.S. fisheries, ranges from about San Francisco, Calif. (lat. $38^{\circ} \mathrm{N}$ ), to Punta Baja, Baja Calif. (lat. $30^{\circ} \mathrm{N}$ ). The central subpopulation has been fished in both California and Mexico for "reduction" (conversion to fish meal, oil, and soluble protein), bait (live or frozen) for anglers, fresh or canned fish for human consumption, animal food, and anchovy paste.

Northern anchovy biomass (Fig. 14-1) in the central subpopulation averaged 400,000 t during 1964-70, increased rapidly to $1,800,000 \mathrm{t}$ in 1974 , and then declined to $490,000 \mathrm{t}$ in 1978. Although total anchovy harvests since 1983 have been less than the theoretical maximum sustainable yield and the historical levels before 1983, abundance continues to decline 
... Northern Anchovy

Figure 14-1.-Northern anchovy landings by U.S. and Mexican fleets during 1945-90, and biomass (age 1 and older) from 1964 to 1990. slowly. Annual harvests are expected to drop soon because the Mexican reduction fishery is unprofitable and will probably end.

Anchovy landings (Fig. 14-1) in California were less than 50,000 t during $1945-65$ and increased, with the advent of "reduction" fishing, to an all-time high of about $150,000 \mathrm{t}$ during 1975. During 1975-83, U.S. landings declined as the reduction fishery diminished. Since 1983, U.S. landings have been low (less than 10,000 t), mostly for live bait and other nonreduction uses.

No numerical limits are placed on the live-bait catch, but there is a 7,000 $\mathrm{t}$ quota for other nonreduction uses. Regulations also specify an optimum yield for the re- duction fishery based on the biomass of spawning fish.

The well-being of other species, especially the endangered brown pelican which feeds on northern anchovies, is important in anchovy management. Thus, there is a threshold in the optimum-yield formula for reduction fishing to prevent anchovy depletion and provide adequate forage for marine fishes, mammals, and birds. As a final safeguard against depletion, the management plan closes all fisheries in the second year if the spawning biomass falls below 50,000 t for two consecutive years; the closure continues in subsequent years until the spawning biomass equals or exceeds $50,000 \mathrm{t}$.

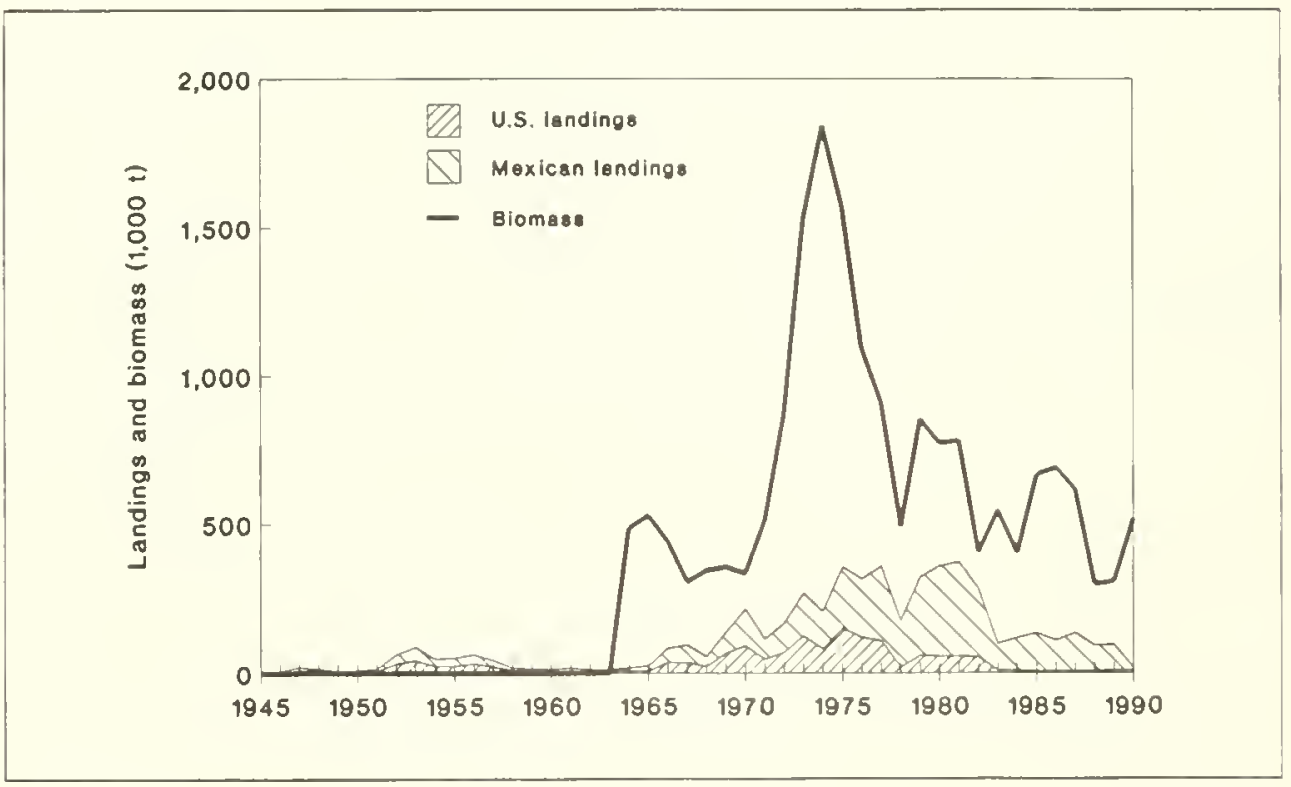

\section{Pacific Sardine}

Pacific sardines once supported the largest fishery in the western hemisphere ( $25 \%$ of all fish landed in the (J.S.) during the 1930's and early 1940's. Their abundance then may have been 2.5 million t. Sardine catches declined after World War II, and the fishery finally collapsed in the early 1960's (Fig. 14-2). A complete moratorium on sardine fishing was imposed in California during the 1967-68 season. Since 1986, small annual quotas of about 1,500 thave been allowed for commercial harvest.

At their peak abundance, Pacific sar- dines were distributed from southeastern Alaska to the Gulf of California. Although primarily a coastal species, sardines have been seen 560 km (350 miles) offshore. California fisheries have been most important in terms of total landings, but fisheries also existed off Oregon and Washington when sardines were abundant.

Like the northern anchovy, Pacific sardines are found in surface schools. They live as long as 10 years and may reach a length of nearly 12 inches $(30 \mathrm{~cm})$. In the past, sardines were harvested for fish meal, 


\section{...Pacific sardine}

Figure 14-2.--U.S. Pacific sardine landings from the $1932-33$ to the $1990-91$ seasons and biomass (age 2 and older) from 1945 to 1965. bait, and human consumption. Currently, there is no fish meal (reduction) fishery, but some sardines are still taken for human consumption and bait.

Pacific sardine numbers off southern California are now increasing. Since 1986, stock biomass has increased about $40 \% /$ year, and the current biomass is about 100,000 t. Commercial demand for sardines is strong, and as catch quotas grow, the fishery is expected to thrive.

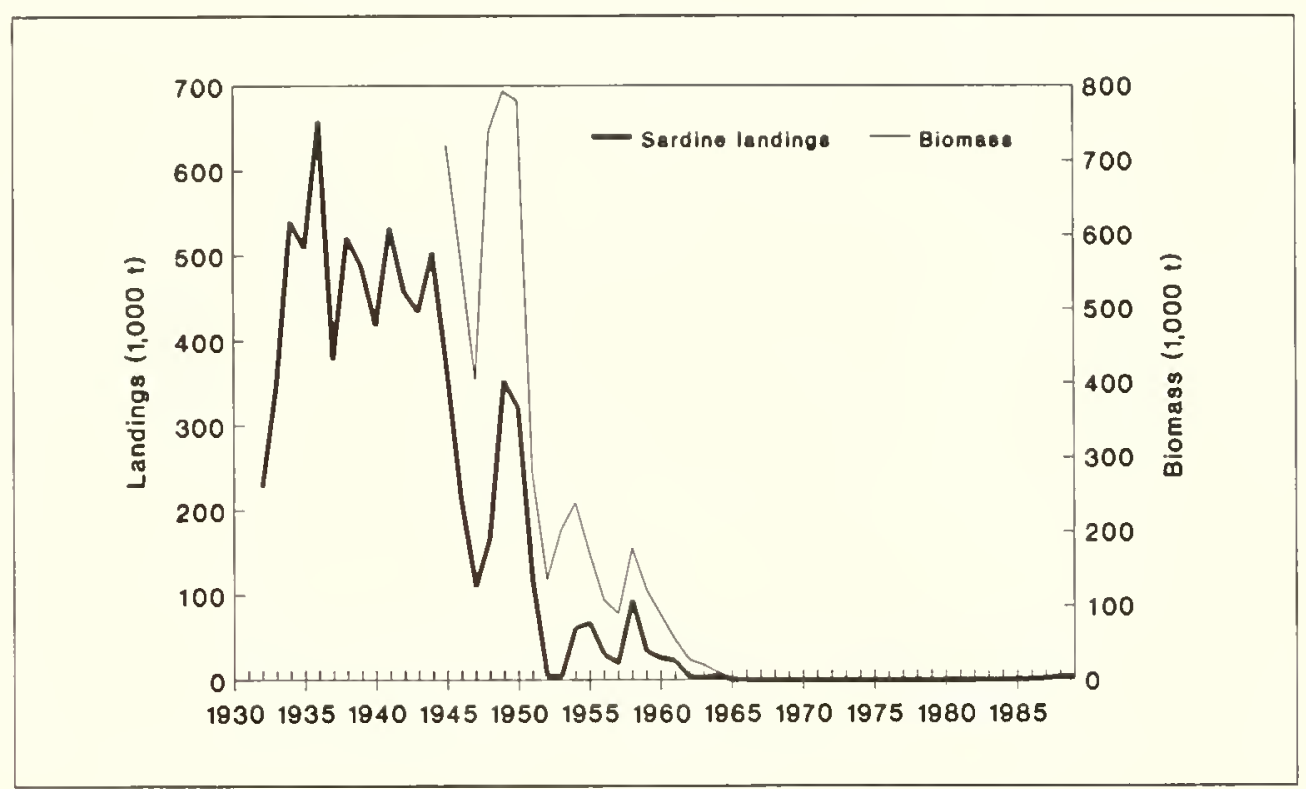

Jack Mackerel
The jack mackerel is similar to several other species of "horse mackerels" found worldwide in temperate marine waters. This species spawns from central Baja California to British Columbia during spring and summer. Juveniles spend several years in their nursery grounds in the Southern California Bight, while older fish move northward, sometimes ranging hundreds of miles from shore, especially off the Pacific Northwest. Jack mackerel reach sexual maturity early in life. Most begin spawning as 1-year-olds, and individuals in offshore waters may live for 30 or more years.

The southern California jack mackerel stock has been fished since the late 1940's when it began to substitute for the failing sardine fishery. The purse seine fishery for it has continued at a low level. Jack mackerel and Pacific (or chub) mackerel are not identified separately on landings receipts and are considered commercially equivalent. Jack mackerel is slightly less favored by purse seine fishermen, however, because it ranges farther from port and frequents rocky bottom areas which can damage nets. There is currently no catch limit.

The large adults found offshore are sometimes caught incidentally by trawlers, particularly those targeting Pacific whiting. During the 1970's, the foreign whiting trawlers may have caught $1,000-2,000 \mathrm{t}$ annually, but the foreign and joint-venture catches in the 1980's dropped to $100 \mathrm{t}$ or less. The foreign trawl fisheries of the 1970 's resulted in jack mackerel management being placed in the Groundfish FMP. An incidental catch of 12,000 t/year (north of lat. $39^{\circ} \mathrm{N}$ ) was set to account for the incidental take; restrictions on fishing for other groundfish species, like whiting, were thus avoided. In 1991, interest by foreign, joint-venture, and domestic industries increased, and the catch limit was raised to $52,000 \mathrm{t}$ to allow a mackerel fishery to develop. While that fishery failed to materialize, strong signs of commercial interest continue.

Jack mackerel have a rather broad distribution, and their stocks consist of a wide variety of ages and sizes. This makes their assessment and management difficult. 
.. Jack Mackerel

\section{Pacific Herring}

Figure 14-3.-Pacific herring landings in the Gulf of Alaska and eastern Bering Sea, 1977-90.
Mackerel stocks are thought to be about 1.5 million $\mathrm{t}$, but their potential yield is little more than an educated guess. Development of more reliable estimates of stock size and potential yield awaits collection of more data on age structure and reproductive biology which could allow interpretation of existing egg and larval survey data.
The Pacific Fishery Management Council has begun to transfer jack mackerel management from the Groundfish FMP to a new Coastal Pelagics FMP. This will allow both the southern California and the offshore mackerels to be managed in the same plan.
Pacific herrings range throughout Alaska waters. Major concentrations in the Gulf of Alaska occur in southeastern Alaska, Prince William Sound, and Kodiak IslandCook Inlet. Northern Bristol Bay and Norton Sound are major centers of abundance in the Bering Sea. Fewer herrings are found in the Chukchi Sea and Arctic Ocean; fishable concentrations have only been found in Kotzebue Sound.

Herrings are fished in state waters, and they are managed by the Alaska Department of Fish and Game (ADFEG). Since the early 1970's, fishermen have concentrated on harvesting roe-herring, though a small amount is taken for bait. Herrings were harvested in the eastern Bering Sea EEZ by foreign fisheries from 1959 to 1980 when allocations ended, prohibiting herring harvests in Federal waters.

The ADFEG regulates and monitors 20 separate herring fisheries, in which 40,700 $t$ valued at $\$ 27$ million were harvested in
1990. Most were roe-herring $(34,500 \mathrm{t})$, and the rest went for food and bait $(6,200$ t) and roe-on-kelp (400 t).

Gulf of Alaska harvests have averaged 18,000 t since 1977 (Fig. 14-3). Bering Sea catches rose from $14,000 \mathrm{t}$ in 1977 to peak at nearly $37,000 \mathrm{t}$ in 1985 . Since 1985 , that catch has been declining. Herrings taken in the Bering Sea groundfish fishery cannot be retained, but are counted as part of the catch. The herring bycatch averaged $2,000-4,000 \mathrm{t}$ in the foreign and joint-venture fisheries, but may have been higher in the domestic trawl fishery.

Overall herring abundance in the Gulf of Alaska is at moderate to high levels, though some stocks are depressed or declining. A strong 1984 year-class is reported in most fisheries. Also, the very strong 1988 year-class reported in southeastern Alaska and Prince William Sound waters is expected to further boost Gulf of Alaska herring abundance in 1992.

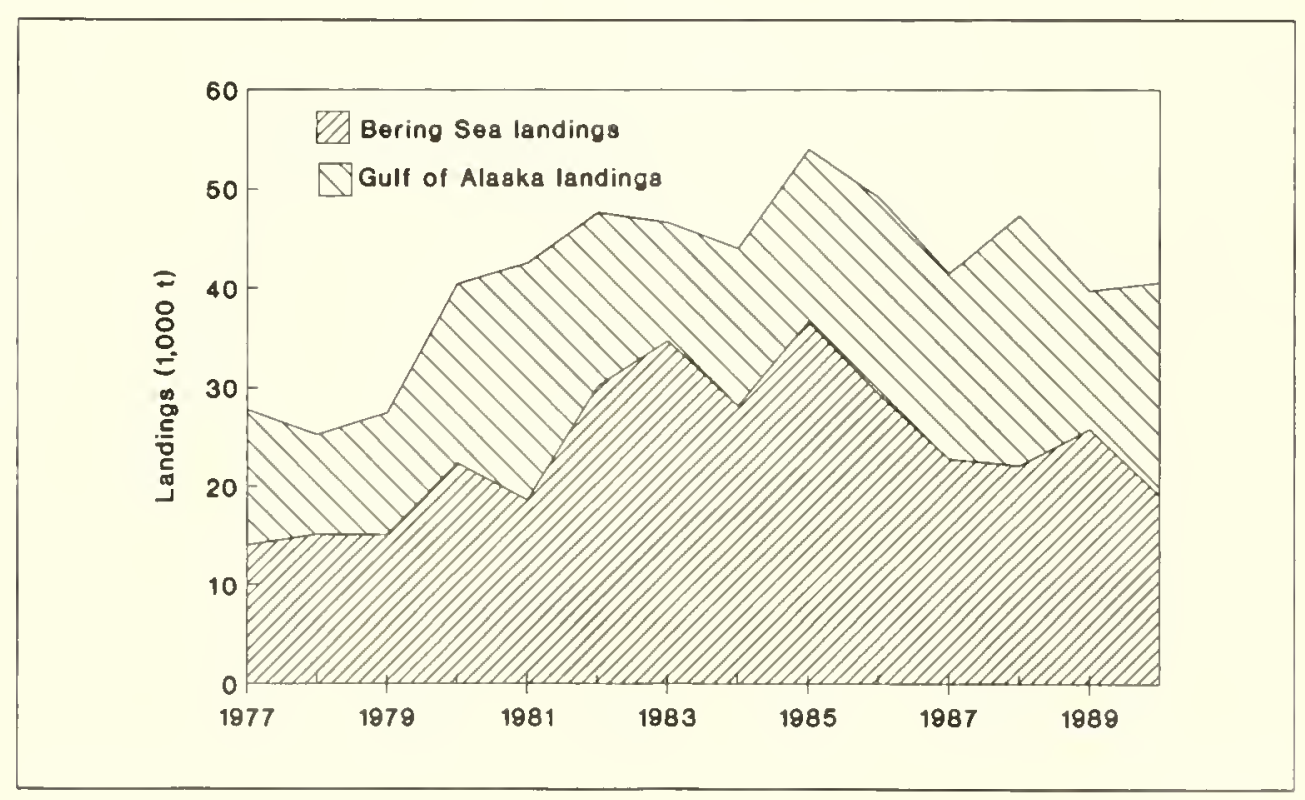


... Pacific Herring
Herrings have declined in the southeastern Bering Sea, but are stable-to-increasing in the northeastern Bering Sea. The 197778 year-classes were very strong and have sustained the fisheries through the 1980's. Historically, a strong year-class has occurred at 5- to 6-year intervals, but none occurred in the 1980's. Unless recruitment improves soon, declines are expected to continue in spawning areas south of Norton Sound. These declines would hurt $\mathrm{Na}$ tive subsistence fisheries, inshore roe fisheries, and the Bering Sea groundfish fishery if the herring bycatch is high.
Special trawl, ichthyoplankton, or hydroacoustic surveys for mackerel are too large in geographical scope and too expensive to conduct regularly. Much of the necessary management information will have to be derived from the fishery, such as distribution, catch rates, and samples of fish to analyze their ages, reproductive status, growth rates, etc. 


\section{INTRODUCTION}

Figure 15-1.- The 15-year trend in Pacific coast groundfish landings. Yield is partitioned into domestic shoreside landings of all species, foreign harvest of Pacific whiting, and joint venture harvest of Pacific whiting.
The Pacific coast groundfish fishery includes 83 species managed by the Pacific Fishery Management Council (PFMC) in the U.S. EEZ off Washington, Oregon, and California. These groundfish, which include 12 species of flatfishes and 55 different rockfishes, are harvested commercially by trawl, trap, and hook-and-line gear. Sport fishermen operate from shore, private boats, and charter or commercial passenger fishing vessels.

The commercial catch of Pacific coast groundfishes by foreign and U.S. fishermen has changed greatly in recent years (Fig. 15-1). Shoreside landings of all species increased from $43,000 t$ in 1975 to a peak of $116,000 t$ in 1982 and is well monitored through state and Federal cooperation in the Pacific Fishery Information Network (PacFIN). Since 1982, shoreside landings have run 82,700-97,700 t; the latter figure, landed in 1989, was valued at $\$ 67,500,000$.

A foreign fishery for Pacific whiting (formerly called hake) began in the mid-1960's and peaked at $240,000 \mathrm{t}$ in 1976. That catch declined as quotas were imposed and a joint-venture (U.S.-foreign) fishery began to develop. In 1989 the joint-venture fishery harvested 203,600 $t$ (valued at $\$ 21,600,000)$ and completely displaced the foreign Pacific whiting fishery.

The recreational groundfish catch in 1986 was $13,900 \mathrm{t}$ (excluding fish landed dressed), including $42 \%$ rockfish and lingcod. The recreational catch in 1986 was substantial only for lingcod $(1,400 t)$ and rockfish $(5,500 t)$. Anglers took $43 \%$ of the total lingcod catch and $13 \%$ of the total rockfish catch, but the recreational percentage was much greater for some rockfish species in certain areas. Determining the value of this recreational fishery is a priority research need of the PFMC.

Most groundfish are caught by trawlers. In 1989, midwater trawlers delivered 203,600 t of Pacific whiting to foreign processors at sea, and shoreside deliveries of all species included $83,800 \mathrm{t}$ from trawls, 2,000 t from traps, 5,800 t from longlines, and 6,100 t from other and unspecified gears. The recent average yield (RAY) of Pacific whiting is $177,000 \mathrm{t}$, ten times greater than the RAY of any other species (Table 15-1).

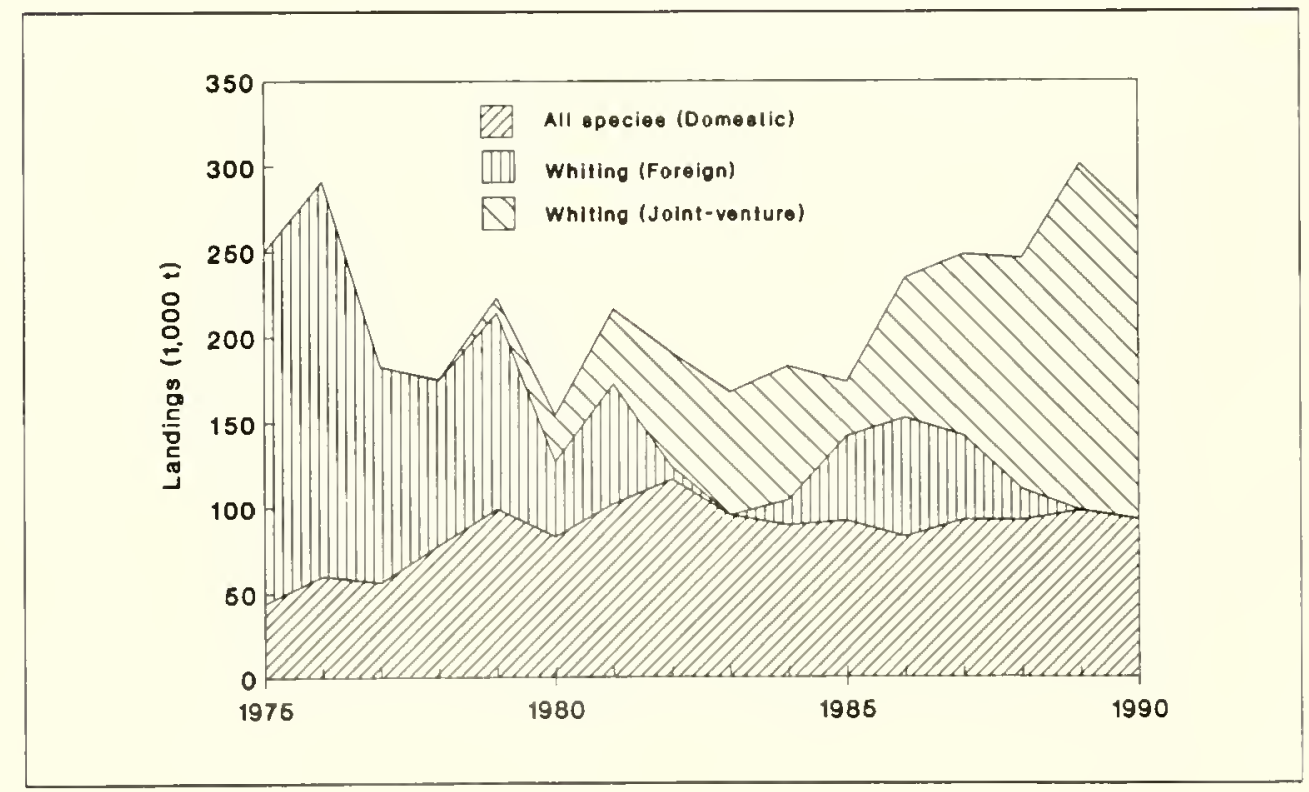


SPECIES AND STATUS
Most major west coast groundfishes are now fully harvested (Table 15-1), and recent catches have been controlled by annual quotas or trip limits. Many species can live a long time ( $50+$ years if unfished), but they can support only low harvest rates. Sablefish is such a species whose overall population is coming into equilibrium-that is, its current potential yields are approaching its long-term potential yields (Fig. 152). Recent data indicate that the statuses of Dover sole, yellowtail rockfish, canary rockfish, and widow rockfish are similar. Pacific whiting reached full utilization in 1989 (Fig. 15-3). Its CPY is very close to its LTPY, but this is changing. The CPY for whiting will likely vary because this species has greater short-term natural fluctuations than most other groundfish species. Shortbelly rockfish and jack mackerel are underutilized, but no market has yet developed for them.

Pacific ocean perch and bocaccio are below potential population levels. The long-lived perch was heavily fished by foreign nations in the 1960's and 1970's. Its population is slowly growing, and its CPY is zero, though some harvest is allowed as bycatch. Bocaccio is a shorter-lived southern species that has had several years of poor reproduction and no stock assessment updates. The 1990 assessment showed that the harvest needed to be cut $50 \%$ to reduce the risk of further declines. Specific species assessments follow.

\section{Pacific Whiting}

Pacific whiting stocks are well studied, with accurate ageing, hydroacoustic stock surveys, and an assessment model that analyzes all fishery and survey data while taking into account environmental effects on the stock. Still, this is not enough to help forecasts of 3-5 years owing to yet unpredictable values. The greatest management problems for this species are bycatch of salmon, allocation of catch between the U.S. and Canada, and allocation between onshore and offshore fisheries.
Table 15-1.-Recent average, current potential, and long-term potential yields in metric tons $(t)$ of Pacific coast groundfish. The LTPY, CPY, and RAY for the unit equals the sum of the species' LTPY'S, CPY'S, and RAY's. Where the species' LTPY is unknown, the species' CPY is substituted in the sum. If the species' CPY is unknown, the species' RAY is substituted. $\begin{array}{ll}\text { Long-term potential yield (LTPY) }= & 357,773 t \\ \text { Current potential yield (CPY) }= & 308,738 t \\ \text { Recent average yield }(\text { RAY })^{1}= & 264,946 t\end{array}$

\begin{tabular}{|c|c|c|c|c|}
\hline \multirow[b]{2}{*}{ Species } & \multicolumn{3}{|c|}{ Yield (t) } & \multirow{2}{*}{$\begin{array}{l}\text { Status of } \\
\text { utilization }\end{array}$} \\
\hline & RAY' & CPY & LTPY & \\
\hline Pacific whiting & 177,381 & 228,000 & 226,000 & Full \\
\hline Sablefish & 11,279 & 8,900 & 8,700 & Full \\
\hline Dover sole & 18,413 & 22,500 & 16,300 & Full \\
\hline English sole & 2,321 & 1.900 & 4,500 & Full \\
\hline Petrale sole & 2,157 & 3,200 & 3,200 & Unknown \\
\hline Thornyheads & 5,752 & 7,900 & Unknown & Unknown \\
\hline Widow rockfish & 11,947 & 7,000 & 8,300 & Full \\
\hline Bocaccio C-M-E ${ }^{2}$ & 1.750 & 800 & 2,400 & Over \\
\hline Canary rockfish & 2,227 & 2,900 & 3,500 & Full \\
\hline Pacific ocean perch & 1,090 & 0 & 2,500 & Over \\
\hline Shortbelly rockfish & 0 & 13,000 & 29,000 & Under \\
\hline Yellowtail V-C ${ }^{2}$ & 4,903 & 4,300 & 4,200 & Full \\
\hline Other rockfish C-M-E & 8,273 & Unknown & Unknown & Unknown \\
\hline Other rockfish V-C & 5,671 & 4,500 & Unknown & Unknown \\
\hline Lingcod & 2,887 & 7,000 & 7,000 & Unknown \\
\hline Pacific cod & 2,595 & 3,200 & Unknown & Unknown \\
\hline Jack mackerel & 0 & 52,500 & 12,000 & Under \\
\hline Other fish & 6,300 & Unknown & Unknown & Unknown \\
\hline
\end{tabular}

'1988-90 average.

${ }^{2}$ All values are coastwide except V.C is Cape Blanco, Oreg. to northern Vancouver Island, B.C.; C-M.E is U.S -Mexican border to Cape Blanco. Oreg. Where a rockfish specoes is harvested outside the specified area, it is included with "Other rockfish." 
Figure 15-2.-The 20-year trend in total catch (domestic and foreign) of sablefish in the U.S. EEZ and the estimated trend in biiomass for ages 3 and older.
Figure 15-3.-The 20-year trend in domestic and foreign catch of Pacific whiting in the U.5. EEZ, total quota for harvest in the U.S. EEZ since 1978 , and estimated trend in biomass for ages 2 and older.
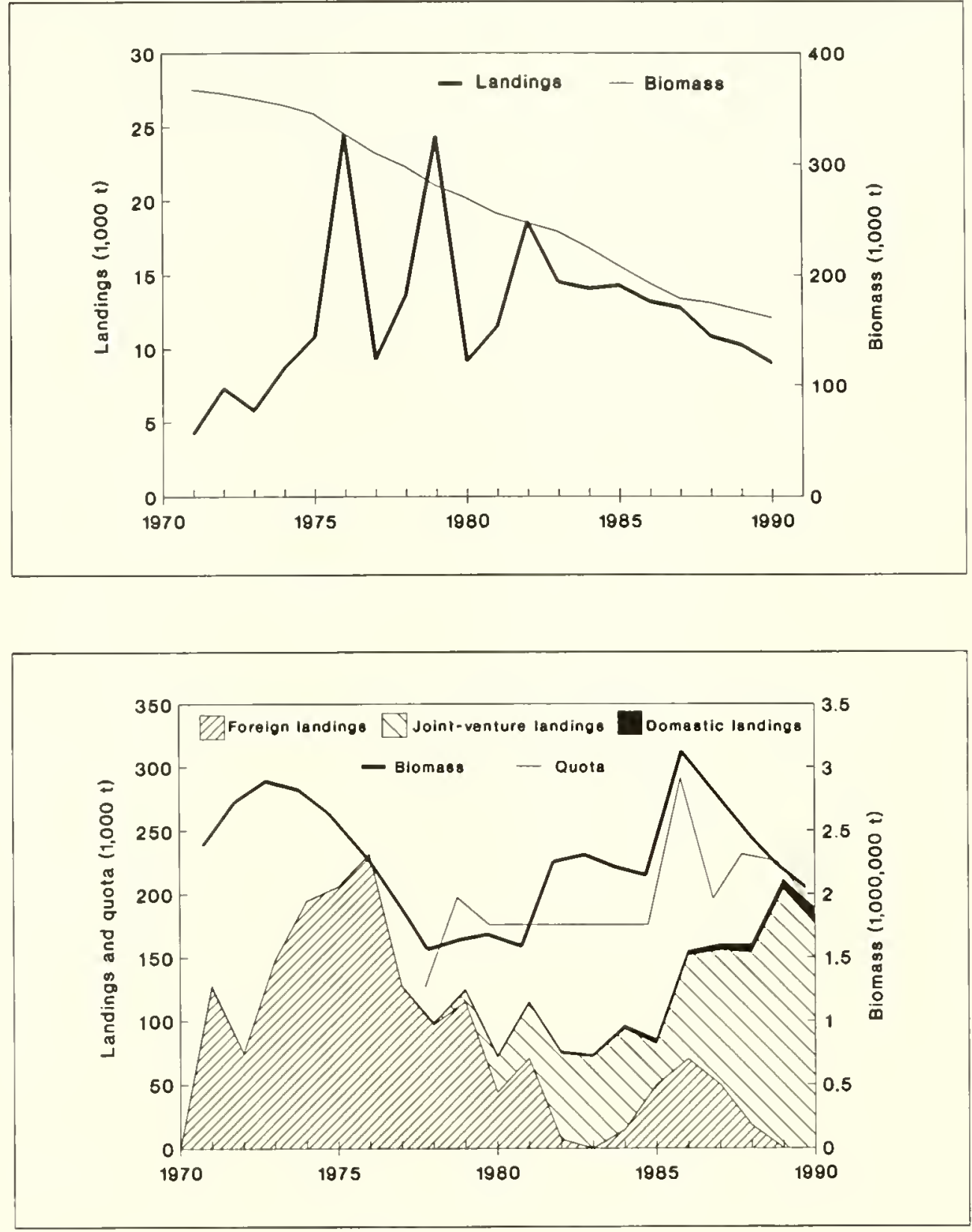

\section{Sablefish}

Sablefish assessment is hampered by lack of data. The size and age composition of the commercial catch has only been monitored since 1986, and trawl surveys at $100-700 \mathrm{fm}$ have only been conducted in a small part of the species' wide range.
Imprecise age and stock determinations must be clarified by further research. Other problems are catch allocations between trap and longline fishermen and incidental catches of sablefish by trawlers fishing for other species.

\section{Dover sole}

Dover sole stock assessment suffers from the same lack of extensive, quantitative trawl survey data and similar stock mixing problems as sablefish. Although fishery catch and fishing effort data have been collected for several years, interpretation has been confounded by changing market conditions. 


\section{... Pacific Coast Groundfish Fisheries}

other Flatfish
Important flatfishes, other than Dover sole, are English and petrale soles and arrowtooth flounder. English and petrale soles have long histories of stable harvests, but they were last assessed in the mid1980's. The arrowtooth flounder fishery has recently expanded in part of its range, and more research on them is needed.
Thornyhead
Thornyheads are harvested in deep water with sablefish and Dover sole. Their catch nearly tripled from 1987 to 1990 owing to increased demand. Data are not yet available for a full stock assessment, but the extremely long life of shortspine thornyheads indicates that their harvest rate must remain lower than sablefish and Dover sole.

\section{Rockfish}

\section{ISSUES}

surveys
Rockfishes are also hard to assess. The age of the six major species caught has been well monitored, but more and better data are needed for accurate stock assess- ment. Better survey methods must be developed. Assessment of the 50-plus lesser rockfish species will be an even bigger, but necessary, task.

\section{Catch statistics}

Most needed are quantitative surveys to verify the assessments of fish stocks. These should include expansion of traw! surveys, calibration of catch rates, and development of alternate survey methods.
All groundfish catches must be monitored accurately. The PacFIN program monitors only groundfish landings and the biological characteristics of some species. Expansion of this program would provide full biological monitoring for most species and an estimate of the amount of fish discarded owing to restrictions (trip limits) on keeping some species. A fishing vessel observer program may be necessary to develop this estimate.

The problem of monitoring discarded fish is tied in with the many species caught during a fishing trip. We know little of the true probability that species are caught together and of the fishermen's ability to alter these probabilities by selective fishing. Thus, we are unable to predict how changes in a single-species trip limit will affect the catch and discard of different fishes caught together. We also have made little progress in managing species that are caught together and which have different productivity levels (e.g., thornyheads caught with Dover sole). Questions of biological interactions among species are even further from our level of understanding.

\section{Allocations}

Allocation of "available catch" to different groups is a difficult and sometimes controversial management problem. The Fishery Management Council must cope with a U.S.-Canada whiting allocation, onshoreoffshore whiting allocation, fixed gear-trawl allocation of sablefish, and recreationalcommercial competition for some rock- fishes. Technical assessment of these issues generally rests on an economic analysis that rarely has adequate information on all sectors of the fishing industry. For some of these problems, individual transferable shares have been identified as a potential long-term solution. 
Excess Harvesting capacity
Perhaps the most difficult problem is managing the excess harvesting capacity: There are simply too many boats and gear for the fish available. Today, more and more severe trip limits frustrate fishermen, managers, enforcement agents, and biolo- gists alike. Tomorrow, the problem could shift to unexpected stock declines. A fishing license limitation program is being considered by the Pacific Fishery Management Council. 
INTRODUCTION

\section{SPECIES AND STATUS}

\section{Lobster}

Table 16-1.-Recent average, current potential, and long-term potential yields in metric tons (t), and status of utilization of Western Pacific invertebrate fisheries. The LTPY, CPY, and RAY for the unit equals the sum of the species' LTPY's, CPY's, and RAY's.

Figure 16-1.-The main (MHI) and Northwestern (NWHI) Hawaiian Islands.
Important invertebrate fisheries in the Western Pacific have included spiny and slipper lobsters and the gold, bamboo, and pink corals. The fisheries are relatively re- cent and range from the Hawaiian Islands EEZ to Guam, American Samoa, and various U.S. Pacific islands.
Spiny and slipper lobsters are fished in the Western Pacific, primarily in the Northwestern Hawaiian Islands (NWHI) area (Fig. 16-1). They are not plentiful outside this region. The fishery began in 1977, and a Fishery Management Plan (FMP) took effect in 1983. The NWHI are uninhabited so all harvests are commercial-there is no recreational fishery. In recent years about 15 vessels have combined to make about 1 million trap hauls. The vessels, all relatively large, carry about 800 traps which they use on 2-month fishing trips. The fishery is managed by the Western Pacific Regional Fishery Management Council (WPFMC).

Recent lobster landings (Fig. 16-2) have been $80 \%$ spiny lobsters. Value of the 1990 landings was $\$ 6$ million. Fishing effort in recent years has been close to 1 million trap-hauls-about the level which achieves LTPY (625 t) (Table 16-1). The lower landings in 1990 were attributed to poor recruitment due to environmental events.
Long-term potential yield (LTPY) $=628 \mathrm{t}$

Current potential yield $(C P Y)=\quad 602 \mathrm{t}$

Recent average yield $(\text { RAY })^{1}=\quad 580 \AA$

\begin{tabular}{lrrrr}
\hline Species group & \multicolumn{3}{c}{ Yield $(\mathrm{t})$} & Ltatus of \\
\cline { 2 - 5 } & RAY & CPY & & utilization \\
\hline $\begin{array}{l}\text { Spiny and } \\
\text { slipper lobsters }\end{array}$ & 580 & 600 & 625 & Fu'l \\
Precious corals & 0 & 1.5 & 2.5 & Under \\
\hline
\end{tabular}

'1988-90 average.

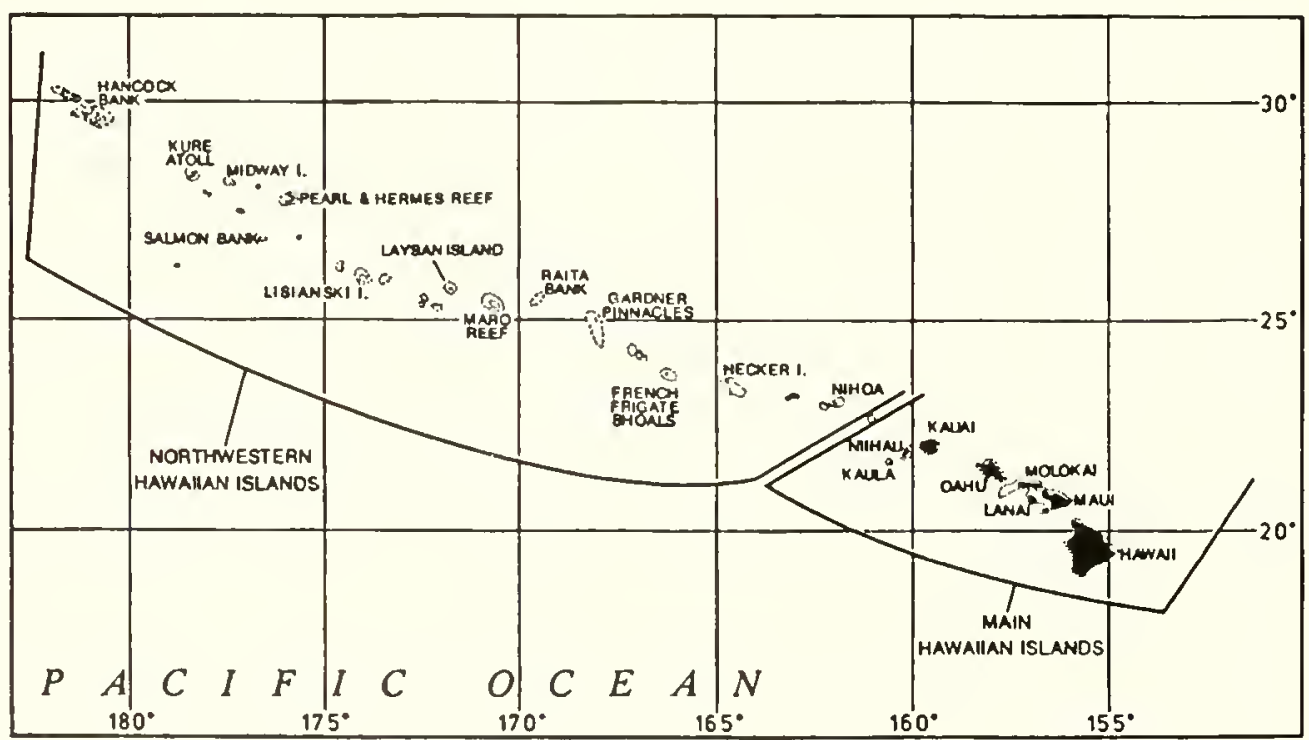


Figure 16-2.-Spiny and slipper lobster landings and fishing effort in Hawaii, 1977-90.

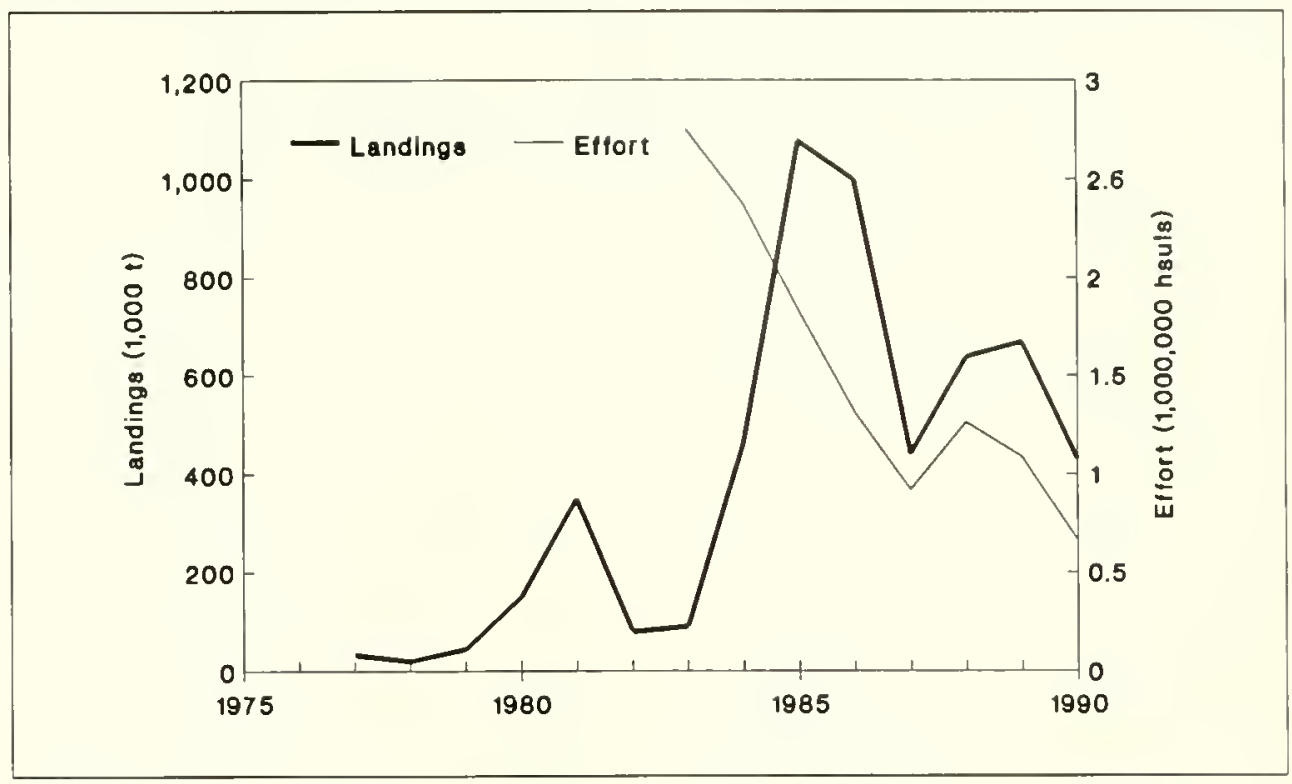

\section{coral}

Figure 16-3.-Landings of precious corals from Hawailan waters, 1966-90.
A short-lived (1974-79) fishery for several gold and bamboo corals and for pink coral existed off Makapu'u Point, Oahu, Hawaii. Since then, the prohibitive cost of fishing such difficult-to-harvest, deep-water corals has stifled U.S. exploitation. With the exception of one aborted attempt at Hancock Seamount in the Hawaiian EEZ in 1988, legal domestic harvesting of precious coral within the EEZ has been nonexistent for 12 years (Fig. 16-3). There are no recreational coral fisheries. Precious corals within the EEZ are managed under the Precious Coral FMP, set in September 1983 by the WPFMC. Fishing is by regular or "experimental" fishing permit only. The FMP regulates precious coral fisheries within the EEZ management unit seaward of the MHI and NWHI, Guam, American Samoa, and the U.S. Pacific Island possessions of Johnston Atoll, Kingman Reef, and Palmyra, Wake, Jarvis, Howland, and Baker Islands.

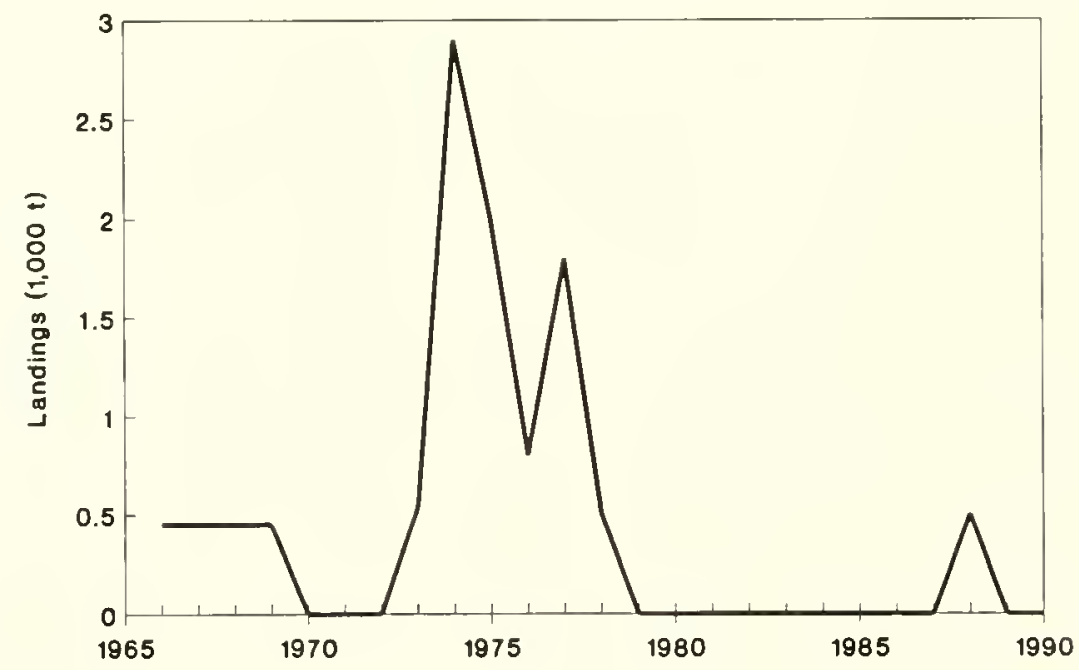




\section{. Western Pacific Invertebrate Fisheries}

Management of the spiny and slipper lobsters is difficult because the number of young lobsters entering the fishery each year varies widely. We need to know the cause of this variation so we can predict it.
Preliminary research suggests that annual variation in current flow along the Hawaiian ridge may be the cause, but we need to pursue these studies to verify this hypothesis. 


\section{INTRODUCTION}

The bottomfish fishery geographically encompasses the Main Hawaiian Islands (MHI), the Northwest Hawaiian Islands (NWHI), the Territory of Guam, the Commonwealth of the Northern Marianas Is- lands (CNMI), and the Territory of American Samoa (Table 17-1). In contrast, the pelagic armorhead is fished on several undersea peaks called "seamounts."

\begin{abstract}
Table 17-1.-Recent average, current potential, and long-term potential yields in metric tons $(t)$, and status of utilization of bottomfish and pelagic armorheads. The LTPY, CPY, and RAY for the unit equals the sum of the species' LTPY'S, CPY's, and RAY's.
\end{abstract}

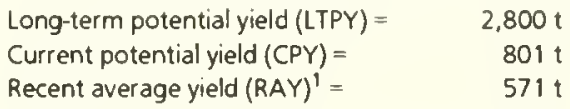

\begin{tabular}{|c|c|c|c|c|}
\hline \multirow[b]{2}{*}{ Species and area } & \multicolumn{3}{|c|}{ Yield (t) } & \multirow{2}{*}{$\begin{array}{l}\text { Status of } \\
\text { utilization }\end{array}$} \\
\hline & RAY ${ }^{1}$ & $\mathrm{CPY}$ & LTPY & \\
\hline \multicolumn{5}{|l|}{ Bottomfish } \\
\hline MHI & 386 & 386 & 271 & Over \\
\hline NWHI & 129 & 335 & 335 & Under \\
\hline American Samoa & 21 & 31 & 31 & Under \\
\hline Guam & 20 & 25 & 25 & Under \\
\hline CNMI & 15 & 24 & 15 & Under \\
\hline Pelagic armorhead & 0 & 0 & 2,123 & Over \\
\hline
\end{tabular}

${ }^{1} 1988.90$ average.

\section{SPECIES AND STATUS}

\section{Bottomfish}

In Hawaii, the bottomfish species fished include several snappers, jacks, and groupers, while in the more tropical waters of Guam, CNMI, and Samoa the fishes include a more diverse assortment of species within the same families as well as several species of emperors. They are found on rock and coral bottoms at depths of $50-400$ $\mathrm{m}$.

The Guam, CNMI, Samoa, and MHI fisheries employ relatively small vessels on 1-day trips close to port; much of the catch is taken by either part-time or sport fishermen. In contrast, NWHI species are fished by full-time fishermen in relatively large vessels on trips of up to 10 days and far from port. Fishermen use the handlining technique in which a single weighted line with several baited hooks is raised and lowered with a powered reel.

Catch weight, size data, and fishing effort are collected for each species in the five areas. However, the sampling programs vary in scope between the areas. About $90 \%$ of the total catch is taken in Hawaii, nearly equally divided between the $\mathrm{MHI}$ and the NWHI (Fig. 17-1).

Stock assessments, though somewhat limited, indicate that the spawning stock of at least four major MHI species (opakapaka, ehu, onaga, and ulua) are at only $20-30 \%$ of original levels. Thus, overutilization is a concern, and, the Western Pacific Fishery Management Council has recommended some form of management.

\section{Pelagic Armorhead}

The seamount groundfish fishery targets just one species: The pelagic armorhead. It is fished on many of the undersea peaks of the Hawaiian Ridge and Emperor seamount chains, though only a small area, the Hancock seamount, is within the U.S. EEZ. The armorhead was fished by the Japanese and, until 10 years ago, by Soviet bottom trawlers. The catch peaked in 1972 with catch rates exceeding $60 \mathrm{t} /$ hour but then dropped to very low levels. The combined population on all seamounts collapsed to about $0.5 \%$ of the 1972 level by the early 1980's (Fig. 17-2). The catch was regulated on Hancock seamounts in 1977 under a Preliminary Management Plan, but catches still declined and fishing was stopped in 1984. In 1986, under the Bottomfish and Seamount Groundfish FMP, a 6-year fishing moratorium was im- 
Figure 17-1.-U.S. landings and catch per unit of effort of bottomfish from fisheries off the a) main Hawaiian Islands (MHI and b) Northwest Hawaiian Islands (NWHI).
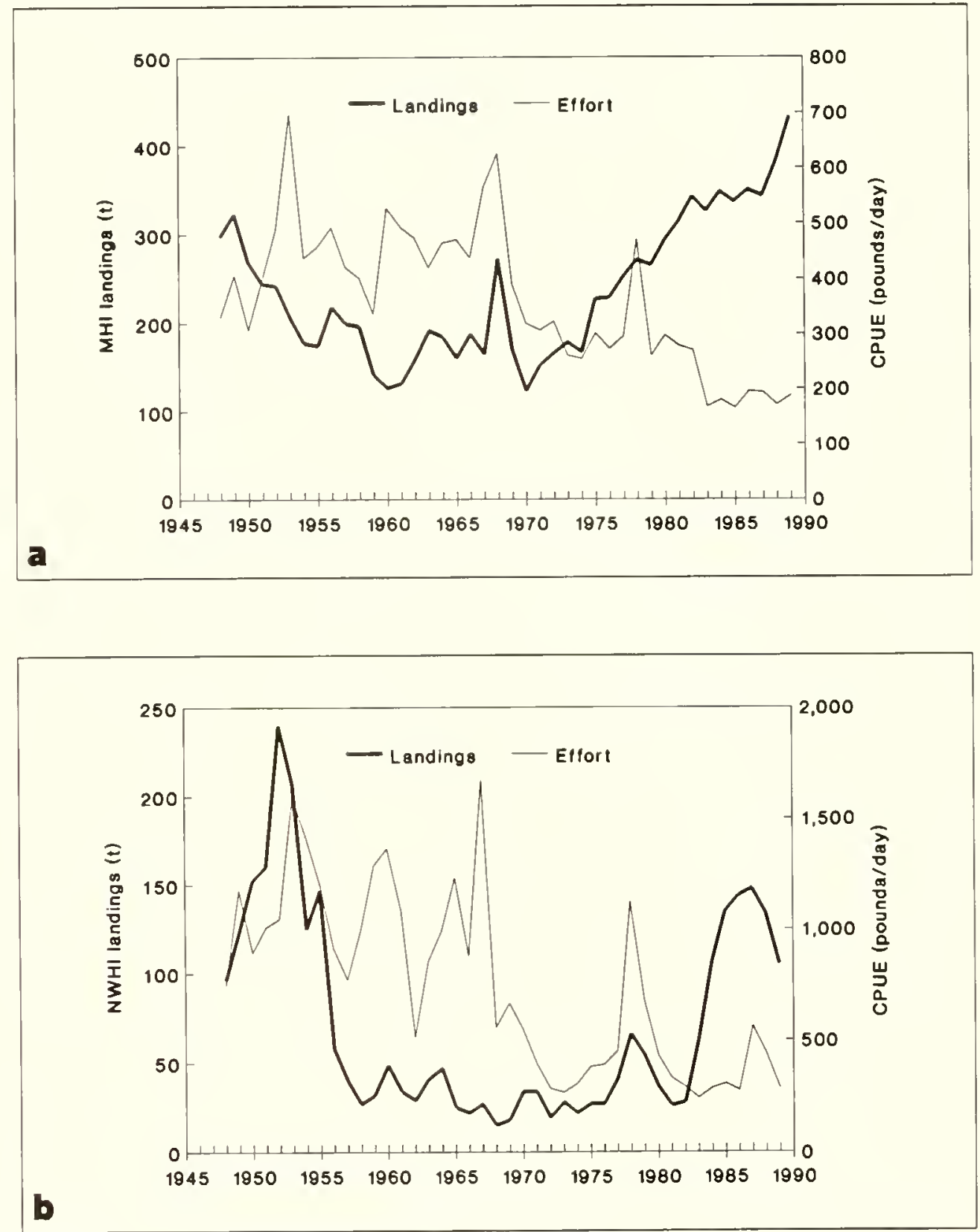

\section{... Pelagic Armorhead}

posed on the Hancock seamounts.

The long-term potential yield (Table 17-

1 ) is $2,123 \mathrm{t}$, but further recovery is needed to achieve that level.

Standardized stock assessments began in 1985. Research cruises focus on the S.E. Hancock seamount and sample the armorhead stock with bottom longlines, calibrated against Japanese trawling. Catch rates vary but have not shown the increases expected after the fishing moratorium was implemented (Fig. 17-3). Closure of only the small U.S.-EEZ portion of the armorhead's distribution probably was insufficient to allow population recovery. 
Figure 17-2.-Catch per unit of effort of pelagic armorheads caught in the commercial Japanese trawl fishery on Pacific seamounts, 1970-84.
Figure 17-3.- Catch per unit of effort of pelagic armorheads taken on longlines during research cruises to Hancock Seamount, 1985-90.
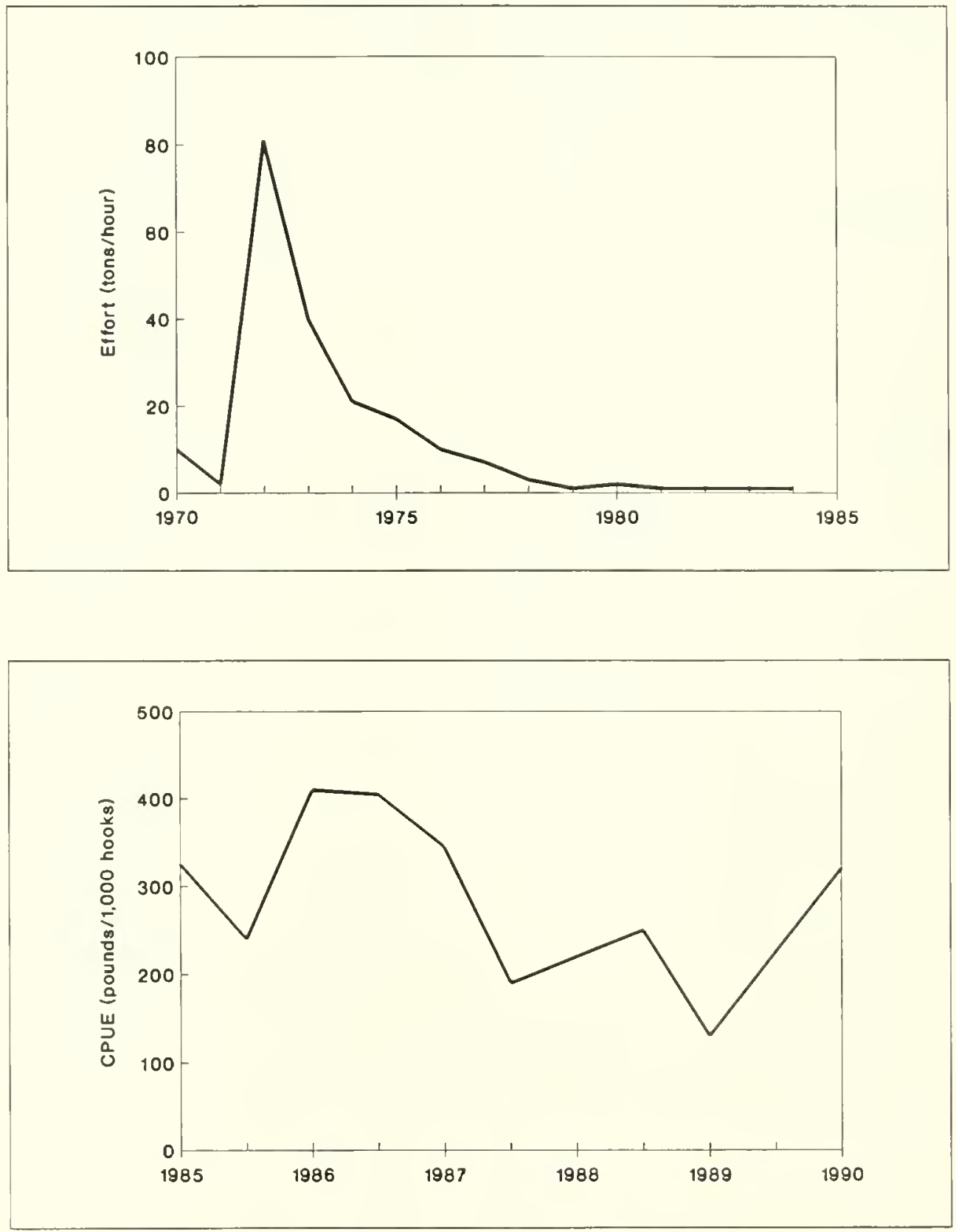

Adequacy of the biological and catch data collected is a primary management concern for the Western Pacific bottomfish fishery. For example, the reproduction of many of the important species in Guam, CNMI, and Samoa is unknown, and spawning numbers cannot be computed. The primary issue now for the pelagic armorhead and its seamount fishery is how to halt the armorhead harvest outside the
U.S. EEZ via some form of international agreement so the stock can recover.

The spawning stocks of at least four important MHI fishes (opakapaka, ehu, onaga, and ulua) appear to be at about $20-30 \%$ of original levels. Thus, overutilization is a concern and management has been recommended by the Western Pacific Fishery Management Council. 
INTRODUCTION
The fishes in this group range the high seas and often are outside U.S. fisheries management jurisdiction. The status of several is either precarious or unknown. Some species are sought vigorously by both commercial and sport fishermen.

\section{SPECIES AND STATUS}

Highly migratory species include tropical tunas (yellowfin and skipjack), albacore, billfishes, sharks, and other large pelagic fishes. Most are caught commercially, but some, especially certain billfishes, support important recreational fisheries as well.

\section{Tropical Tunas}

The tropical tunas (yellowfin and skipjack) are fished with longlines across the Pacific, whereas the purse seine is the primary gear in the Eastern Tropical Pacific (ETP) and the Central-Western Pacific (CWP) regions. Fishing in both the ETP and CWP is generally between lat. $20^{\circ} \mathrm{N}$ and $20^{\circ} \mathrm{S}$. Mexico is the primary fishing nation in the ETP. Others include the United States, Vanuatu, Venezuela, and some other coastal nations. Major fishing nations in the CWP are the United States, Japan, Korea, and Tai- wan. Current, recent, and long-term potential yields for the various species are given in Table 18-1.

About $90 \%$ of the Pacific yellowfin tuna catch is taken by purse seine, pole-andline, longline, and handline. Purse seiners account for $30-50 \%$ of the catch. Virtually all skipjack tuna is taken by pole-and-line and purse seine.

During 1970-80, the ETP fishery was expanding and dominated by the United States. Fishing became less profitable in
Table 18-1.-Recent average, current potential, and long-term potential yields in metric tons $(t)$, and status of utilization for Pacific highly migratory species. The LTPY, CPY, and RAY for the unit equals the sum of the species' LTPY'S, CPY'S, and RAY's. Where the species' LTPY is unknown, the species' CPY is substituted in the sum. If the species' CPY is unknown, the species' RAY is substituted.

$\begin{array}{ll}\text { Long-term potential yield (LTPY) }= & 1,649,928 \mathrm{t} \\ \text { Current potential yieid }(\text { CPY })= & 1,569,261 \mathrm{t} \\ \text { Recent average yield }(\text { RAY })^{1}= & 1,599,261 \mathrm{t}\end{array}$

Recent average yield $(\text { RAY })^{1}=\quad 1,599.261 \mathrm{t}$

\begin{tabular}{|c|c|c|c|c|}
\hline \multirow[b]{2}{*}{ Species and area } & \multicolumn{3}{|c|}{ Yield $(t)$} & \multirow{2}{*}{$\begin{array}{l}\text { Status of } \\
\text { utilization }\end{array}$} \\
\hline & RAY' & CPY & LTPY & \\
\hline Yellowfin tuna (CWP²) & 280,000 & Unknown & Unknown & Unknown \\
\hline Yellowfin tuna (ETP ${ }^{3}$ ) & 280,000 & 250,000 & 250,000 & Full \\
\hline Skipjack tuna (CWP) & 767,000 & Unknown & Unknown & Under \\
\hline Skipjack tuna (ETP) & 87,000 & Unknown & Unknown & Under \\
\hline Albacore (North Pacific) & 46,000 & Unknown & 120.000 & Over \\
\hline Albacore (South Pacific) & 43,000 & Unknown & Unknown & Unknown \\
\hline Blue marlin & 18,742 & Unknown & 23,500 & Over \\
\hline Black marlin & 1,765 & Unknown & 1,765 & Unknown \\
\hline Striped marlin & 14,951 & Unknown & 16,000 & Under \\
\hline \multicolumn{5}{|l|}{ Sailfish and } \\
\hline shortbill spearfish & 4,392 & Unknown & Unknown & Unknown \\
\hline Swordfish & 24,140 & Unknown & 25,000 & Unknown \\
\hline Wahoo & 101 & Unknown & Unknown & Unknown \\
\hline Mahimahi & 23,539 & Unknown & Unknown & Unknown \\
\hline Pompano & Unknown & Unknown & Unknown & Unknown \\
\hline Requiem sharks & 8,137 & Unknown & Unknown & Unknown \\
\hline Thresher sharks & 268 & Unknown & Unknown & Unknown \\
\hline Hammerhead sharks & 0 & Unknown & Unknown & Unknown \\
\hline Mackerel sharks & 226 & Unknown & Unknown & Unknown \\
\hline
\end{tabular}

\footnotetext{
${ }^{1} 1988.90$ average

${ }^{2} \mathrm{CWP}=$ Central-Western Pacific Ocean.

${ }^{3} \mathrm{ETP}=$ Eastern Tropical Paafic Ocean.
} 
... Tropical Tunas

Figure 18-1.-U.S. skipjack tuna landings from the Pacific Ocean, the eastern tropical Pacific (ETP), and the central-western Pacific (CWP), 1970-90. the 1980's and many U.S. fishermen quit or moved to the CWP, leaving Mexico the dominant fleet in the ETP with over 50 purse seiners. U.S. vessels decreased to about 10 in 1990-91 in response to dolphin safety concerns. Purse seiners (all countries) in the ETP in 1991 numbered over 125.

Gears used in the CWP fishery include purse seine, ring net, handline, pole-andline, and longline. Purse seiners, dominated by the United States and Japan, take $30-50 \%$ of the yellowfin tuna catch. In 1989 the total number of purse seiners in the CWP was more than 120. In 1990-91 about 50 U.S. seiners operated in the CWP.

Currently, there is no international tuna management in the ETP; each coastal nation regulates fishing within its own EEZ. Until 1980 the Inter-American Tropical Tuna Commission (IATTC) regulated the international fishery with catch quotas. Since then, IATTC regulations have been suspended because Mexico is not an IATTC member.

Also, there is no overall resource management program in the CWP, though the Forum Fisheries Agency (FFA), which represents the affected South Pacific island nations, has instituted a licensing program for foreign (distant-water) fishing fleets through access agreements. The U.S. fleet is currently limited to 50 purse seiners in the FFA region under an access agreement (South Pacific Regional Tuna Treaty).

More skipjack tuna are caught than any other tunas. Recent average yield (RAY) of Pacific skipjack tuna is $767,000 \mathrm{t}$ from the CWP (Fig. 18-1) and 87,000 trom the ETP; angler catches are small. The species is believed underutilized, though the longterm potential yield (LTPY) is unknown. The annual dockside value of the Pacific skipjack tuna catch is about $\$ 680$ million, and for yellowfin tuna it is $\$ 450$ million, based on a conservative dockside price of $\$ 800 / \mathrm{t}$ for both species.

The recent average yield of yellowfin tuna for the entire Pacific is about 560,000 t (Table 18-1), distributed about equally between the ETP and the CWP (Fig. 18-2). Recent assessments of yellowfin tuna indicate that the LTPY for the ETP is about $250,000 \mathrm{t}$, making this fish fully utilized. The LTPY for the CWP is unknown because a comprehensive analysis of potential yield has not been performed. However, catch rates are fairly steady, and preliminary analyses of stock condition suggest that the fishery may be nearing full production.

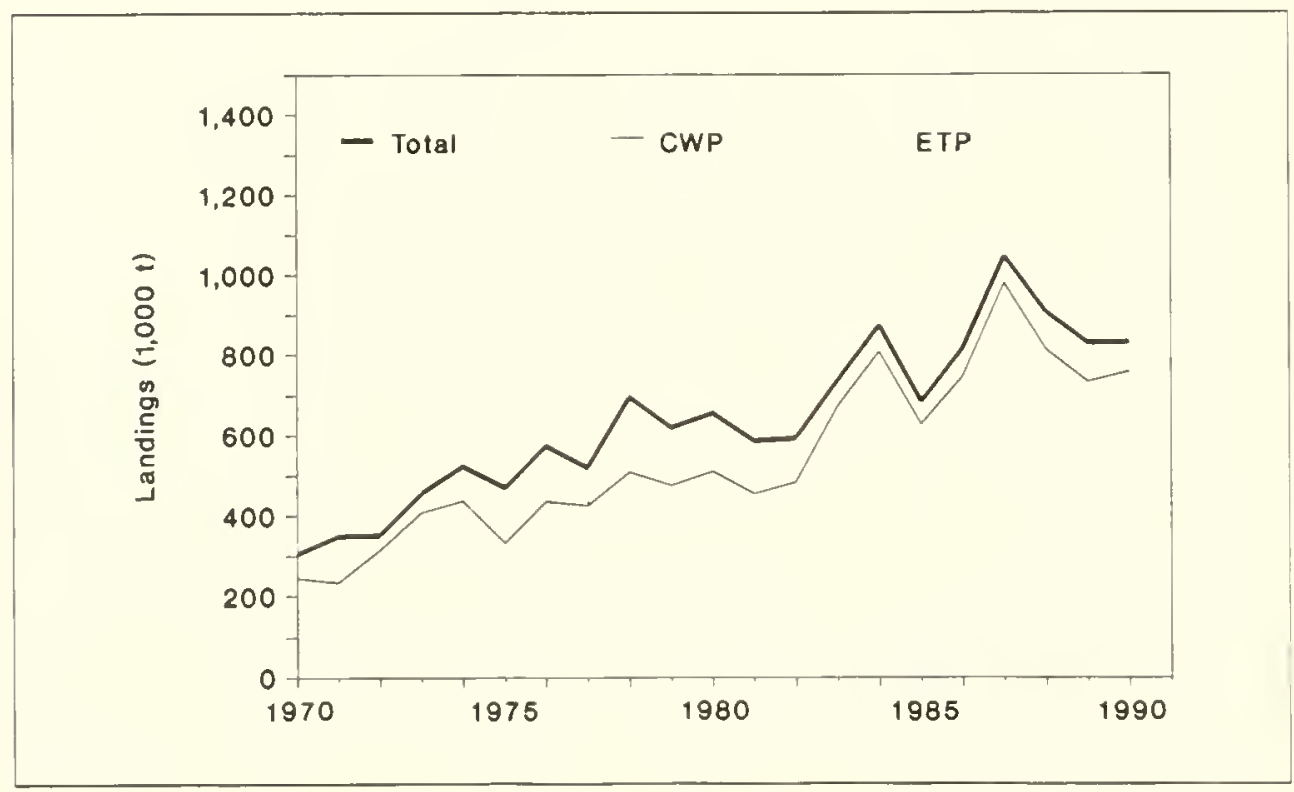


Figure 18-2.-U.S. yellowfin tuna landings from the Pacific Ocean, the eastern tropical Pacific (ETP), and the central-western Pacific (CWP), 1970-90.

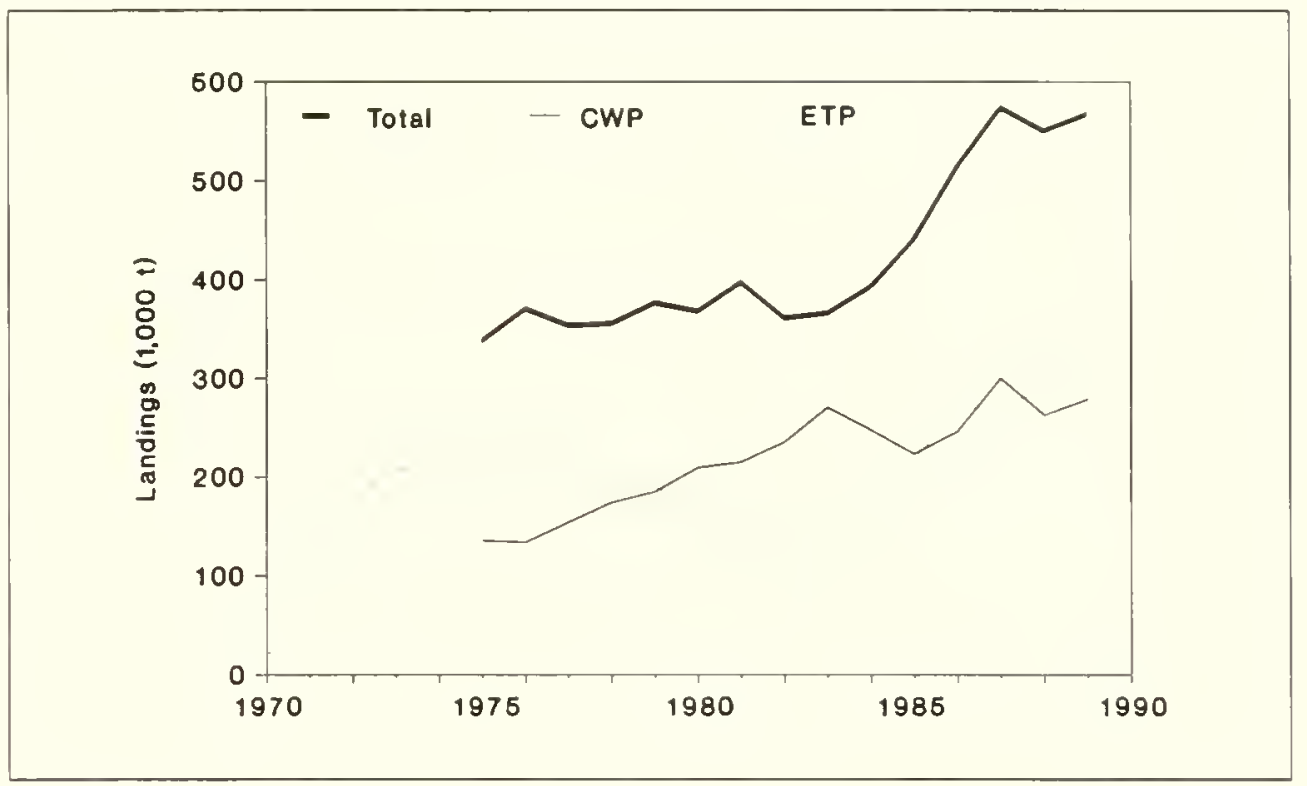

North Pacific albacore is fished from the northern limits of the Subtropical Convergence Zone (STCZ) to about lat. $15^{\circ} \mathrm{N}$, and from Japan to North America. In the South Pacific, it is fished from about lat. $15^{\circ} \mathrm{S}$ to the southern limits of the STCZ and from South America to Australia.

In the North Pacific, albacore are fished primarily by longline, pole-and-line, drift gill net, and trolling. Longline gear is used in the lower latitudes, and this gear accounts for about $20-25 \%$ of the current catches. The surface fisheries (pole-and-line, drift gill net, troll) operate in the more temperate regions and account for $75-80 \%$ of the catches. The U.S. fishery in the North Pacific extends from the middle of the North Pacific to North America and uses between 500 and 2,000 vessels. Based on a dockside value of $\$ 2,200 / t$, the annual value of the Pacific albacore catch is about $\$ 195$ million.

South Pacific albacore are fished primarily by longline, drift gill net, and trolling. As in the north, longliners operate nearer the equator. Surface gear is set in the Tasman Sea and in the STCZ at about long. $160^{\circ} \mathrm{W}$. In 1990, about 60 U.S. trollers fished the South Pacific.

Presently, there are no management re- gimes for the North or South Pacific albacore fisheries. In the South Pacific, multinational discussions between Pacific island nations and distant-water fishing nations, including the United States, are being held to explore various management schemes.

The Pacific albacore (both the north and south stocks) has a long history of exploitation (Fig. 18-3). Recent development of a large surface fishery in the South Pacific, in addition to the longline fishery, has changed the previous stock assessments from "fully exploited," under a longline only fishery, to "unknown." No LTPY has yet been estimated, but a comprehensive assessment is needed owing to the rapid expansion of the surface drift net and troll fisheries.

In the North Pacific, the total catch, catch rates, and fishing effort in the U.S. troll fishery and the Japanese pole-and-line fishery have all been declining (Fig. 18-3). Previous assessments estimated LTPY near 120,000 $t$ and stock production at or above LTPY in the 1970's. This high production, coupled with the recent addition of a drift gillnet fishery (for which statistics are incomplete), is probably overutilizing the stock. 
Figure 18-3.-U.S. albacore landings from the Pacific Ocean, the North Pacific, and the South Pacific, 1970-90.

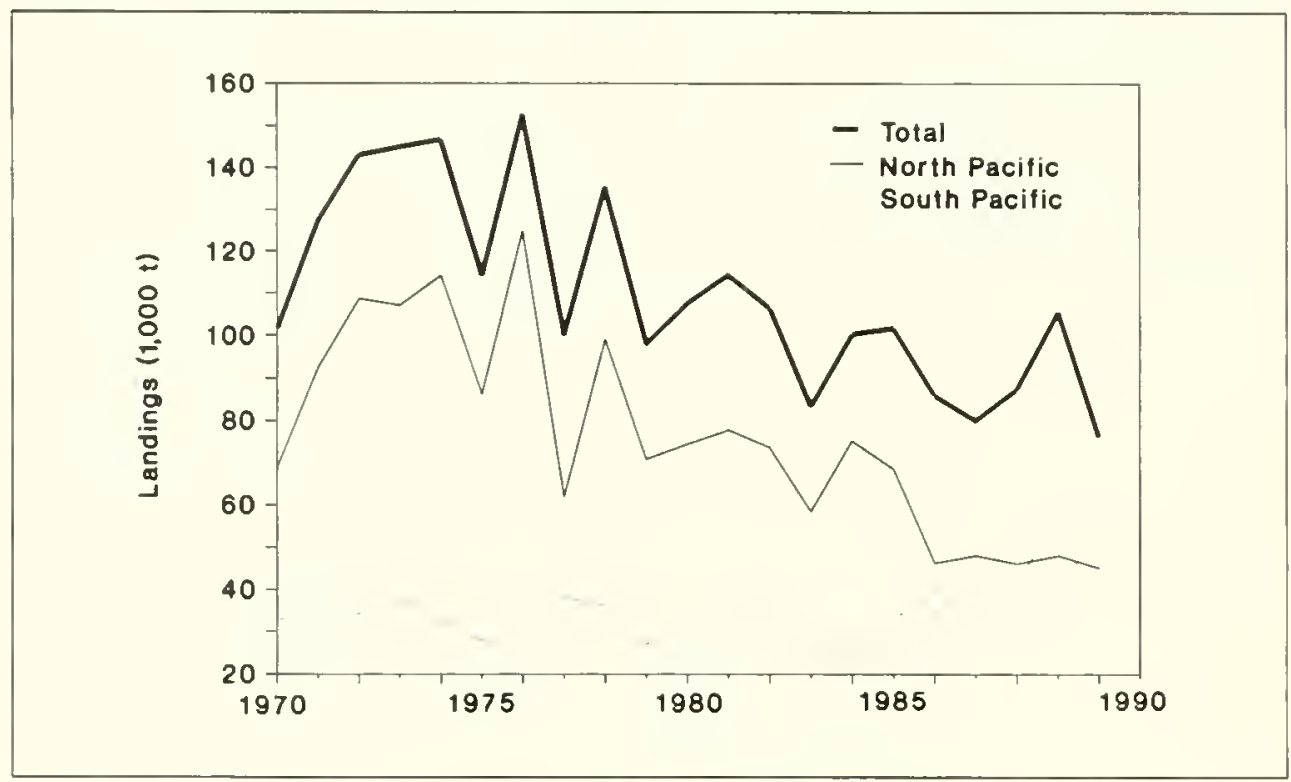

\section{Billfish and other Species}

Species included here are the blue, black, and striped marlins; swordfish, sailfish, shortbill spearfish, wahoo, mahimahi (dolphin fish), pompano, and several oceanic sharks (requiem, thresher, hammerhead, and mackerel). They generally range from North America to Asia and between the North and South Pacific STCZ's. They are more abundant near islands, continental slopes, seamounts, and oceanic fronts, and many are important to local economies; they are caught by foreign and U.S. fishermen, both sport and commercial.

U.S. commercial fishing gears include drift gill nets, handlines, harpoons, longline, trolling, and rod-and-reel. Anglers use only rod-and-reel. Swordfish and thresher sharks are taken by longline around the Hawaiian Islands and by harpoon and drift gill net off North America.

U.S. fisheries are generally dwarfed by foreign fisheries (mostly longline and drift gill net). There is no international authority managing these species in the Pacific. U.S. management authority rests with the Western Pacific Fisheries Management Council for Hawailan and Western Pacific waters, and with the Pacific Fisheries Management Council for North American waters (although the latter has delegated management to the State of California for swordfish, striped marlin, and some sharks). Owing to the many species in this category, no precise value can be calculated for the annual catch. However, the catch of swordfish and blue and striped marlins are each valued in excess of $\$ 2,000 / \mathrm{t}$.

Catches of billfish and other species (Fig. 18-4) have been relatively constant, near $90,000 \mathrm{t}$ per year, with a slight increase in the most recent years (Table 18-1). Four species dominate the "other" catches: Blue and striped marlins, swordfish, and mahimahi.

The status of most species' stocks is unknown. Recent assessments with 10 year-old data indicate that swordfish and striped marlin were utilized slightly below LTPY and blue marlin was fished above LTPY; however, new data is needed to confirm or dispute this finding.

\section{ISSUES}

Tunas
The primary issue facing Pacific tropical tunas is the lack of consensus on a plan for gathering and reporting statistics and for setting up a conservation and management group to represent all interests. The lack of data is critical and prevents tuna assessment, management, and protection. Both North and South Pacific albacore are affected by high-seas drift gill nets. The impact of this fishery on the stocks is not clear; however, data from these fisheries are being collected. In the South Pacific, 


\section{... Pacific Highly Migratory Pelagic Fisheries}

\section{2}

Figure 18-4.-Total U.S. and foreign landings of billfish and other pelagic migratory fish from the Pacific Ocean, 1979-88, and the U.S. landings from the eastern Pacific, 1979-89, and the central-western Pacific (CWP), 1979-90.

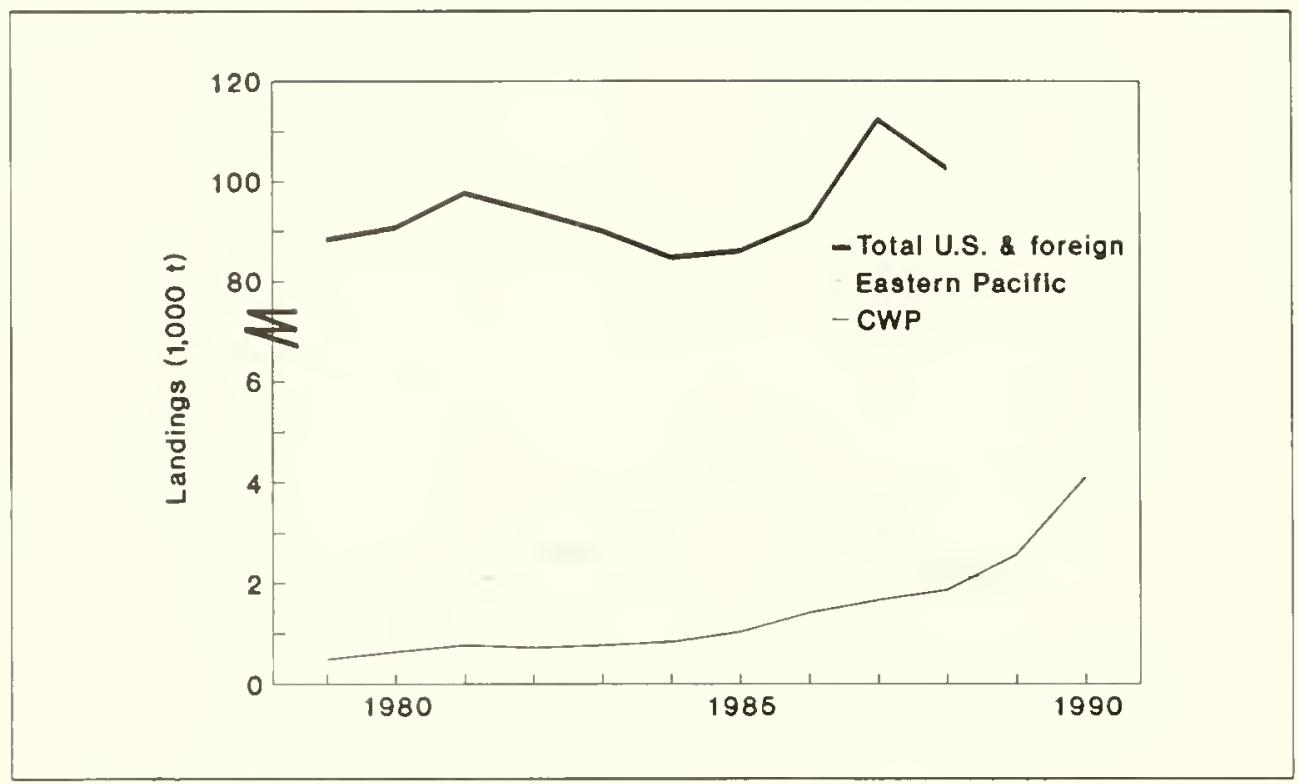

... Tunas

the interaction between the established long-line fishery and a rapidly growing surface fishery (predominately (I.S.) needs attention, particularly if allocation of available yield between the fisheries becomes an issue. The scope, structure, and organization of a multilateral management regime is another issue which needs continued attention.

Population levels of the billfishes and other species is either unknown or out of date: There is no international mechanism to examine data collected on the Pacific-wide stocks. Hence, there is no up-to-date assessment of stock condition, including that portion of the stock that ranges in the U.S. EEZ. Basic biological data (beyond catches) are also lacking or grossly inadequate for most of these species. This limits determination of the current condition of the stocks. Bycatch of these speries by drift gill nets and in other fisheries is another issue. Often these catches go unreported.
The North Pacific stock appears to be overutilized, possibly owing to heavy catches by drift gill nets. Data collection and an evaluation of the effects of the drift gillnet fishery are urgently needed. Creation of an international forum to manage the stock is another issue that needs attention, particularly if the fishing nations want the stock to recover.

The increase in U.S. vessels (longliners) in the Hawaiian EEZ and the Central Pacific high seas and their impact on the swordfish stocks is another concern. In addition, incidental take of protected species (Hawaiian monk seal and sea turtles) is a sensitive issue.

Scientists recognize that at least one species, the Indo-Pacific blue marlin, is and has been depleted and no management mechanism exists to correct the situation. Thresher sharks in the west coast swordfish/shark drift gillnet fishery are heavily fished. 


\section{INTRODUCTION}

Figure 19-1.-The North Pacific Ocean.
The North Pacific (Fig. 19-1) is one of the most productive oceans, supporting many of the world's largest populations of groundfish, salmon, crabs, marine mammals, and seabirds. Large-scale commercial fisheries for groundfish in Alaska waters were developed and dominated by foreign fleets from the early 1950's until the Magnuson Fishery Conservation and Management Act (MFCMA) was passed in 1976. This act produced one of the great success stories for development of a U.S. groundfish industry.

Though foreign fisheries dominated through 1983 (and were important through 1986) (see pages 85,87 ), joint ventures between U.S. fishermen and foreign companies eventually replaced them as experience was gained. Later, even the joint ventures were superseded by domestic fishermen and processors. With the exception of Greenland turbot, the groundfish off Alaska have generally been in good to excellent condition.

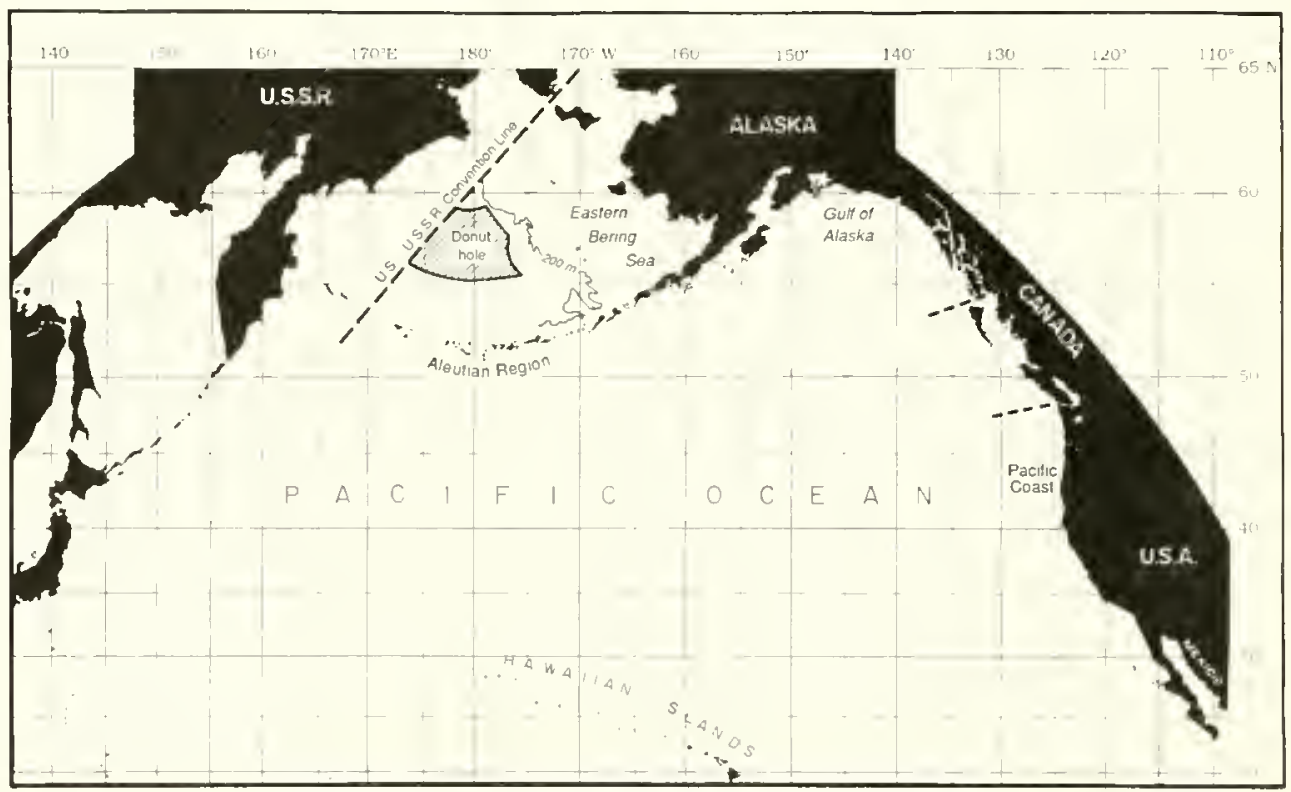

\section{SPECIES AND STATUS}

Pacific Halibut
Pacific halibut has been fished commercially since the late 1800 's; it is now fished only with longline gear, though other gear types accidentally catch some halibut. There is an active recreational fishery as well, and about $3,700 \mathrm{t}$ are landed by anglers.

Halibut is found from the Bering Sea to Oregon, though the center of abundance is in the Gulf of Alaska. The resource is considered as one large interrelated stock but is regulated by subareas with catch quotas and time-area closures.

The Pacific halibut is managed under treaty between the United States and Canada, and primary assessment and management recommendations are provided by the International Pacific Halibut Commission.
In 1990, nearly 37,000 t of Pacific halibut were landed commercially $(31,900 \mathrm{t}$ in the United States and 5,100 $\mathrm{t}$ in Canada) (Fig. $19-2)$ valued at $\$ 115$ million. About 2,000 $t$ were wasted owing to fishing by lost gear and discard, and 10,000 $\mathrm{t}$ were lost to accidental catches by fishermen targeting other species. Over 6,500 U.S. vessels were licensed for the commercial halibut fishery, as were 435 Canadian vessels.

Halibut stocks are assessed annually, and the fishable population apparently peaked at $166,000 \mathrm{t}$ in 198687 after a rebuilding period (Fig. 19-2). The population has since declined at about 5\%/year. Some decline is still expected, but halibut numbers remain fairly high by historical standards. The species is fully utilized (Table 19-1). 
84 abundance trends for Pacific halibut in the North Pacific ocean for U.S. commercial and recreational fisheries and the Canadian fishery, 1980-90.
Figure 19-2.-Landings and

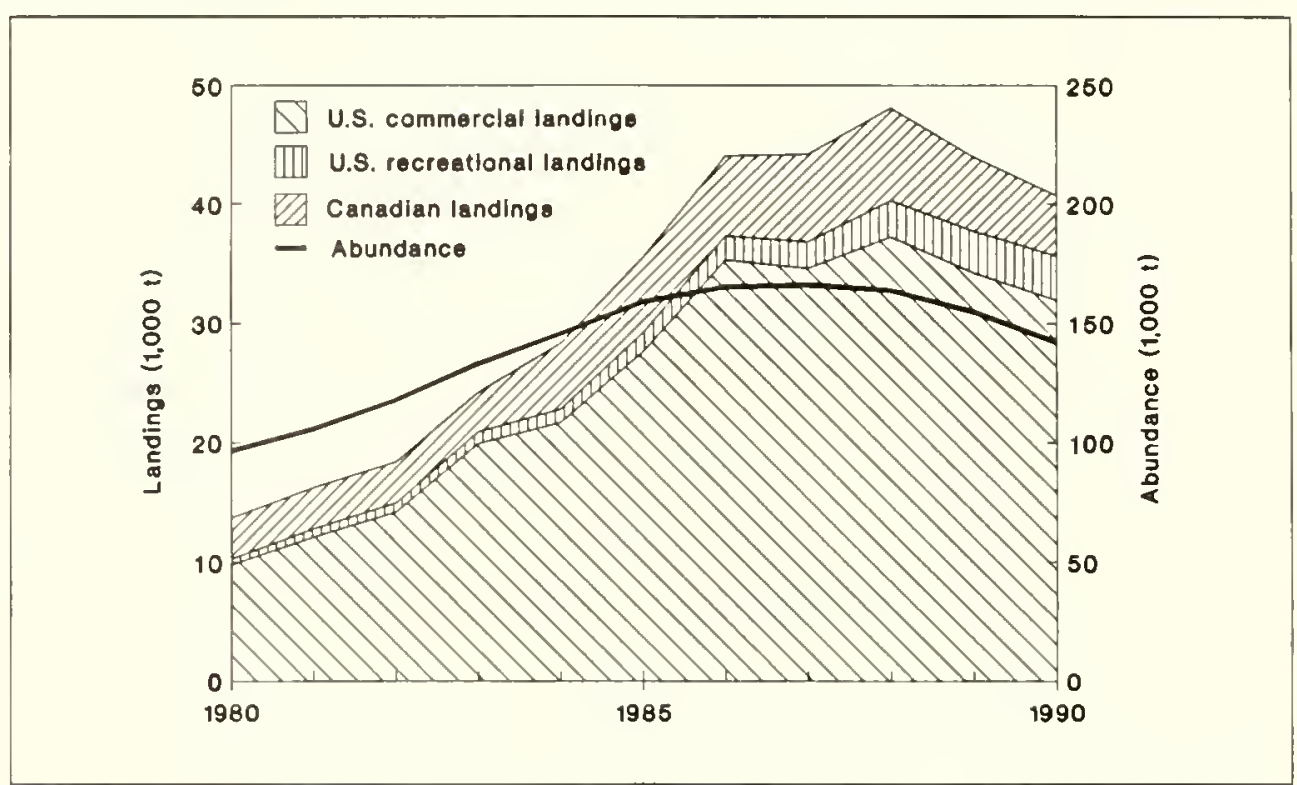

Table 19-1.-Recent average, current potential, and long-term potential yields in metric tons (t), and status of utilization for Pacific halibut. The LTPY, CPY, and RAY for the unit equals the sum of the species' LTPY's, CPY's, and RAY's.
Long-term potential yield $(\text { LTPY })^{1}=$
$20,000 t$
Current potential yield $(\mathrm{CPY})^{1}=$
Recent average yield $(\mathrm{RAY})^{2}=$
$33.500 \mathrm{t}$
$40,800 t$

\begin{tabular}{lrrrr}
\hline & \multicolumn{2}{c}{ Yield $(\mathrm{t})$} & \multicolumn{1}{c}{$\mathrm{CPY}^{1}$} & \multicolumn{1}{c}{$\begin{array}{c}\text { Status of } \\
\text { utilization }\end{array}$} \\
\cline { 2 - 4 } Region & \multicolumn{1}{c}{ RAY $^{2}$} & & \\
Bering Sea-Aleutians & 3,000 & 2,800 & 1,700 & Full \\
Gulf of Alaska & 31,100 & 25,900 & 15,400 & Full \\
Off Pacific coast & 300 & 300 & 200 & Full \\
Off Canadian Pacific coast & 6,400 & 4,500 & 2,700 & Full \\
& & & & \\
\hline
\end{tabular}

'Does not include $16,000 \mathrm{t}$ for sport catch, bycalch, and waste.

2198890 average

${ }^{3}$ Californa, Oregon, and Washington

\section{Bering Sea-Aleutian Islands Groundfish}

The average eastern Bering Sea-Aleutian Islands groundfish catch during 1988-90 was about 1.8 million t (Table 19-2; Fig. 19-3), valued at about $\$ 352$ million in 1990. The dominant groups harvested were walleye pollock, $75 \%$; flatfishes, $15 \%$; Pacific cod, 7\%; Atka mackerel, $1.4 \%$; rockfishes, $0.4 \%$; and sablefish, $0.3 \%$. Revenue from trawl landings increased from $\$ 129$ million in 1988 to $\$ 318$ million in 1990. The pollock fishery increased in value from \$86 million in 1988 to $\$ 255$ million in 1990. Longline vessel revenue also increased, largely due to increased Pacific cod catches, from $\$ 11$ million in 1989 to $\$ 34$ million in 1990 .
Groundfish populations have been maintained at high levels under the MFCMA. Their long-term potential yield (LTPY) is about 2.71 million t. The current potential yield (CPY) of 2.93 million $t$ for 1991 is above LTPY. This potential has not been fully utilized because catch quotas cannot exceed the optimum yield (OY). The OY is conservatively set below CPY, at 2.0 million $t$ out of consideration for both socioeconomic factors and biological yield potential.

Walleye Pollock: Pollock produce the largest single-species catch for the United States. The three main stocks, in decreasing order of abundance, are: Eastern Be- 
Table 19-2.-Recent average, current potential, and long-term potential yields in metric tons $(t)$, and status of utilization for Bering Sea-Aleutian Islands groundfish. The LTPY, CPY, and RAY for the unit equals the sum of the species' LTPY's, CPY's, and RAY's. Where the species' LTPY is unknown, the species' CPY is substituted in the sum.
Figure 19-3.-Landings and abundance trends for groundfish resources in the Bering Sea/Aleutian Islands region for the foreign, joint-venture, and U.S. fisheries, 1976-90.
Long-term potential yield (LTPY) $=2,784,800 \mathrm{t}$

Current potential yield $(\mathrm{CPY})=\quad 2,926,100 \mathrm{t}$

Recent average yield $(\text { RAY })^{1}=\quad 1,790,100 t$

\begin{tabular}{lrrrr}
\hline & \multicolumn{2}{c}{ Yield $(t)$} & LTPY & Status of \\
\cline { 2 - 3 } Species & \multicolumn{1}{c}{ RAY } & & Utilization \\
\hline & & & & \\
Pollock & $1,327,800$ & $1,777,500$ & $1,898,000$ & Full \\
Pacific cod & 178,800 & 229,000 & 192,000 & Full \\
Yellowfin sole & 151,500 & 250,600 & 220,000 & Full \\
Greenland turbot & 8,300 & 7,000 & 27,100 & Full \\
Arrowtooth flounder & 2,200 & 116,400 & 59,000 & Under \\
Rock sole & 43,900 & 246,500 & 160,000 & Under \\
Other flatfish & 41,500 & 219,700 & 148,500 & Under \\
Sablefish & 5,200 & 6,300 & 7,500 & Full \\
Pacific ocean perch & 9,350 & 15,300 & 14,900 & Full \\
Other rockfish & 850 & 1,300 & 1,300 & Full \\
Atka mackerel & 12,400 & 24,000 & 24,000 & Full \\
Other fish & 8,300 & 32,500 & Unknown & Under \\
& & & &
\end{tabular}

'1988-90 average.

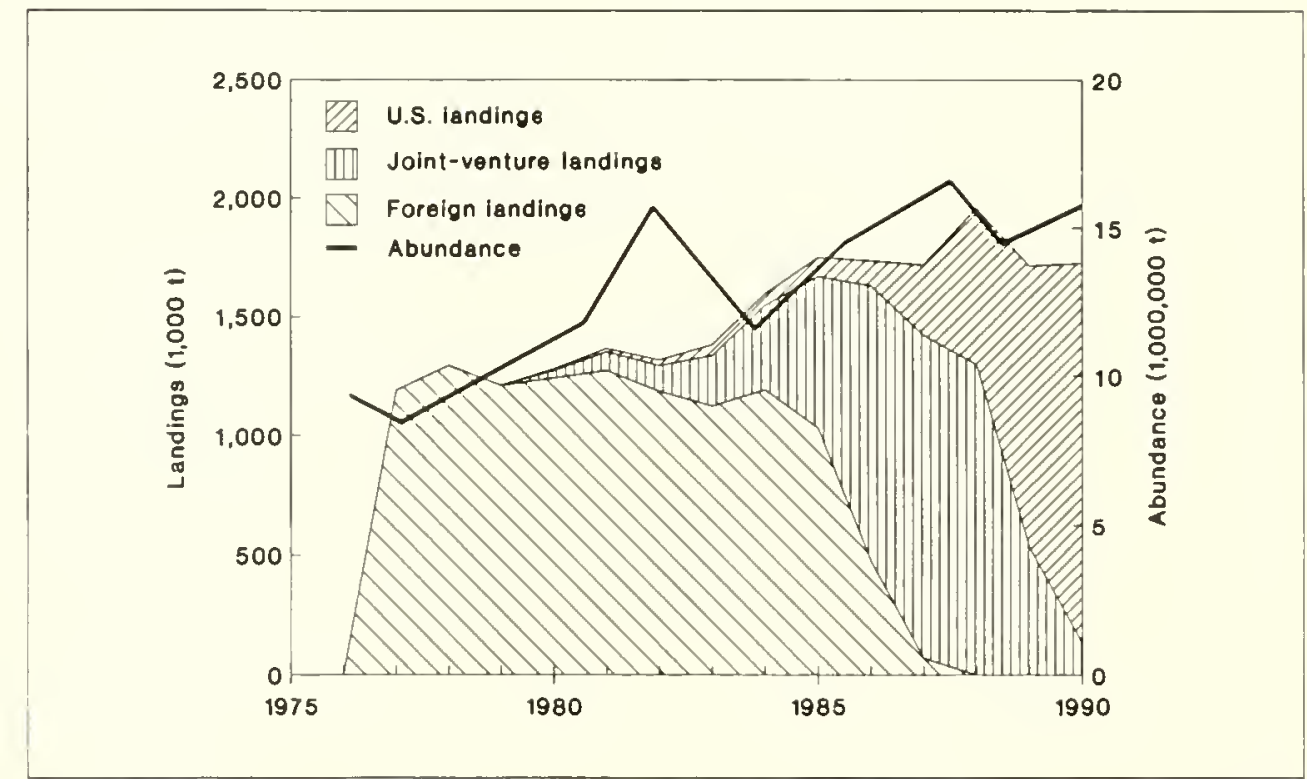

... Bering sea-Aleutian Islands Groundfish ring Sea (EBS) stock, Aleutian Basin (AB) stock, and the Aleutian Islands (AI) stock. The EBS and Al stocks are moderately high (above the levels that produce LTPY) and are now fully utilized.

Another large pollock fishery lies outside the U.S. and Soviet EEZ's in the "donut hole" of the central Bering Sea (Fig. 19-1). This fishery is dominated by Japan, U.S.S.R., Poland, China, and the Republic of Korea. The fishery targets the AB pollock stock during its migration through the donut hole area. Catches from this stock appear far too high. Although the status of the Aleutian Basin stock is not well known, it appears to be declining rapidly.

Pacific Cod: Pacific cod abundance remained high and stable throughout the 1980's. However, the 1990 survey showed a $26 \%$ drop from 1989. This decline and poor production over the past 2 years may be due to changing environmental conditions or ecological relationships. The cod stock is fully utilized.

Flatfishes: Yellowfin sole is the most abundant of the flatfishes. During the 
.. Bering sea-Aleutian Island Groundfish 1950's, the sole was the major trawling target, but it now ranks second to pollock. Yellowfin sole is fully utilized. Greenland turbot, the only depressed flatfish stock, is expected to decline further during the mid1990 's owing to poor spawning success in the 1980 's. It is considered fully utilized.

All other flatfish species are in good-toexcellent condition. Populations continue to be high and increasing for arrowtooth flounder and high and stable for rock sole, flathead sole, Alaska plaice, and other flatfishes. The rock sole is now the secondmost abundant of the flatfishes, increasing substantially from 1980. It is underutilized, as are other flatfishes. Trawl catches are restricted to prevent excessive incidental catches of Pacific halibut and king and tanner crabs.

Sablefish: Sablefish or blackcod is a valuable species caught mostly with longline and pot gear below the depths fished by trawlers. Sablefish is considered to be a single stock from the Bering Sea-Aleutian Islands (BSAI) region to the Gulf of Alaska. The BSAI population declined substantially in 1990, partly due to migration into the Gulf of Alaska. Current abundance is relatively high, though recruitment has not been strong. The sablefish is fully utilized.

Rockflshes: Rockfishes are assessed and managed as two major groups: Pacific ocean perch (POP) and "other rockfish." The POP group consists of the true Pacific ocean perch and four other red rockfish species. POP abundance dropped sharply owing to intensive foreign fisheries in the 1960 's and remained low into the early 1980 's. In recent years, catch levels have been set well below CPY to help rebuild the stocks. The POP group is now recovering and is considered fully utilized.

The "other rockfish" group includes two thornyhead species and about 30 other rockfish species not included in the POP group. Little is known about them, but they are considered fully utilized.

Atka Mackerel: Atka mackerel stocks, mainly in the Aleutian region, are hard to assess because: 1) Survey estimates are highly variable, 2) surveys in the species' Aleutian range were last conducted in 1986, and 3) two of the last three surveys failed to sample shallow waters successfully. Thus, population trends cannot be inferred from survey and catch data. Since Atka mackerel stocks cannot be fully assessed, the CPY is estimated as the average catch levels and the resource is considered fully utilized.

Other Species: In recent years, "other species" catches have represented $1 \%$ or less of the total groundfish catch. Sculpins and skates probably constitute most of this resource, but the abundance of pelagic squids, smelts, and sharks is largely unknown. Owing to insufficient data, the LTPY for "other species" is unknown. The CPY has been set at the average catch levels.

\section{Gulf Groundfish}

Gulf of Alaska groundfish catches have ranged from a low of $135,400 \mathrm{t}$ in 1978 to a high of 352,800 $\mathrm{t}$ in 1984 (Fig. 19-4), with pollock dominant, followed by Pacific cod and sablefish. The 1990 groundfish catches were valued at $\$ 94.4$ million (dockside value). Sablefish comprised about $45 \%$ of the total Gulf value. Other major revenue-producing species in the Gulf of Alaska during 1990 were Pacific cod at $\$ 26$ million, followed by pollock and rockfish.

Groundfish abundance has been relatively stable, rising slowly from 1984 to 1990. Arrowtooth flounder is most abundant, followed by pollock and Pacific cod. In 1990, arrowtooth flounder composed 2 million $\mathrm{t}$ of the Gulf groundfish biomass (5.3 million t); pollock, 1.4 million $\mathrm{t}$; and Pacific cod, 0.5 million $t$. The estimated LTPY for Gulf of Alaska groundfish is $493,600 \mathrm{t}$ (Table 19-3). The CPY is 773,600 $\mathrm{t}$, which contrasts with the RAY of 177,400 t. The wide disparity between the CPY and the RAY is because groundfish fishing is restricted owing to incidental catches of Pacific halibut.

Pollock and Pacific Cod: Pollock appear to be at an average population level, but it is difficult to determine current biomass and an appropriate fishing mortality rate. The pollock is slightly underutilized. Pacific cod are abundant and fully utilized, but are expected to decline. Reproduction has not 
Figure 19-4.--Landings and abundance trends for groundfish resources in the Gulf of Alaska region for the foreign, joint-venture, and U.S. fisheries, 1976-90.

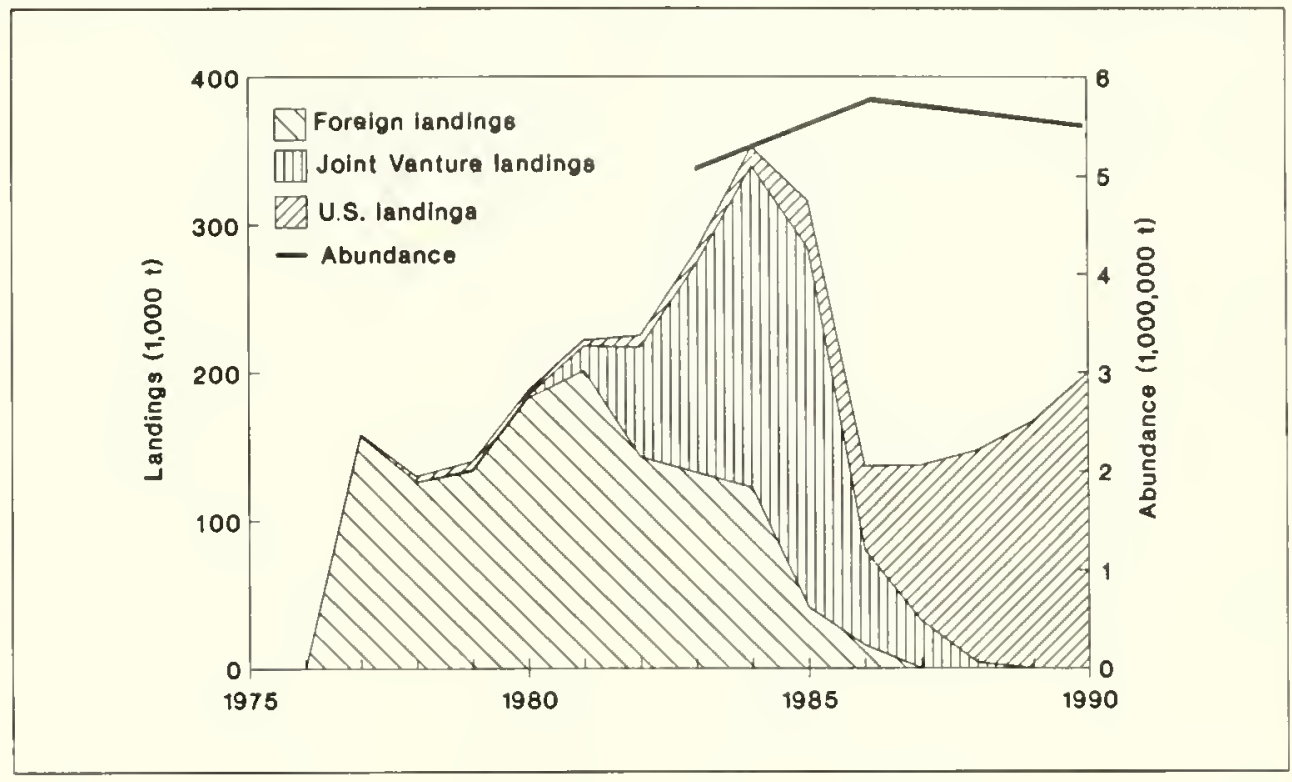

\section{... Gulf Groundfish}

Table 19-3.-Recent average, current potential, and long-term potential yields in metric tons ( $t$ ), and status of utilization for Gulf of Alaska groundfish. The LTPY, CPY, and RAY for the unit equals the sum of the species' LTPY's, CPY'S, and RAY's.

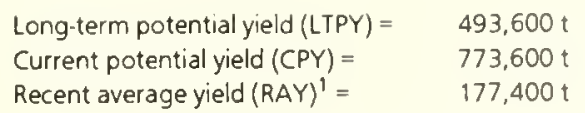

kept pace with natural and fishing losses. Flatfish, Sablefish, and Rockfish: Flatfish are in general very abundant, largely owing to great increases in arrowtooth flounder. Flatfish are managed as deepwater and shallow-water groups, while flathead sole and arrowtooth flounder are managed as separate categories. Sablefish are numerous and are in good condition, though they are projected to decline owing to low recruitment. They are fully utilized.

"Slope" rockfish, those found on the continental slope from the outer edge of the continental shelf down to the abyssal plain, are at low levels and are fully utilized. They grow slowly, are long-lived, have not re bounded from the heavy foreign fishing in the 1960's, and are considered fully utilized. The principal species in this group, Pacific ocean perch, shortraker rockfish, and rougheye rockfish, are highly valued. They are in a separate management category. Thornyhead rockfishes are also believed to be at a low level and decreasing. The population of continental shelf rockfishes (pelagic and demersal) is unknown and needs further research. Managers try to set the fishing mortality rate equal to the natural mortality rate.

\begin{tabular}{lrrrr}
\hline & \multicolumn{2}{c}{ Yield $(t)$} & LTPY & $\begin{array}{c}\text { Status of } \\
\text { Utilization }\end{array}$ \\
\cline { 2 - 4 } Species & RAY & CPY & & \\
& & & & Under \\
Pollock & 66,800 & 133,400 & 229,000 & Full \\
Pacific cod & 50,700 & 77,900 & 39,100 & Under \\
Flatfish & 10,300 & 514,900 & 168,600 & Under \\
Sablefish & 29,000 & 22,500 & 26,600 & Full \\
Slope rockfish & 16,300 & 17,900 & 21,350 & Unknown \\
Thornyhead rockfish & 2,500 & 1,800 & 3,750 & Full \\
Pelagic shelf rockfish & 1,300 & 4,800 & 4,800 & Full \\
Demersal shelf rockfish & 500 & 400 & 400 & \\
& & & &
\end{tabular}


ISSUES

"Donut Hole"

Pollock Fishery
The large unregulated foreign pollock fishery in the "donut hole" of the Bering Sea (Fig. 19-1) is a major concern as it targets the migrating U.S. and U.S.S.R. Aleutian Basin stocks. The fishery is expected to hurt U.S. EEZ pollock stocks. Another major concern is the lack of data to determine the stock's status. The U.S. and U.S.S.R. have begun to cooperate on research and management of the donut hole pollock fisheries.

\section{Marine Mammal Interactions}

Marine mammal interactions with fish and fisheries are a growing concern. Steller sea lions are listed as threatened under the Endangered Species Act, and it must be shown that the groundfish fishery will not interfere with them. Pollock provide food

for sea lions, and some fisheries have occurred near rookeries; however, we lack data to show a cause-and-effect relationship between the pollock fishery and the decline of the sea lions.

fore harvesting the entire groundfish quotas. Various incentive programs are being tested to control bycatches while improving the groundfish harvest. and crab bycatch limits are reached, the groundfish fisheries are closed-usually be-

The incidental catch of Pacific halibut and king and tanner crabs off Alaska now curtails the groundfish fisheries. When halibut

\section{Exxon Voldez oil spill}

In March of 1989, the Exxon Valdez ran aground, spilling about 11 million gallons of crude oil into Prince William Sound which spread into the Gulf of Alaska and lower Cook Inlet. Coastal areas were severely contaminated. Fortunately, no mas- sive die offs of adult fish were found, but some coastal and offshore fishes have remained exposed to petroleum hydrocarbons. Since injuries from chronic exposure to oil may not be seen for many years, studies must be continued. 
INTRODUCTION

\section{SPECIES AND STATUS}

\section{crab}

Figure 20-1.-King crab landings and abundance for the Bering Sea and Gulf of Alaska, 1960-90.
Exploratory crab and shrimp fishing began off Alaska during the 1940's and 1950's. The first major domestic king crab fishery began in the 1960's off Kodiak Island, later expanding to the Aleutian Islands and Bering Sea. Domestic tanner crab fisheries became important during the 1970's, as did the shrimp fisheries of the Gulf of Alaska. A Japanese snail fishery developed in the Bering Sea during the 1970's but ended in 1987. Shellfish fisheries in Alaska waters have shown large fluctuations in landings, owing to extremely variable population size.
Three species of king crabs (red, blue, and golden or brown) and two species of tanner crabs (bairdi and opilio) are harvested commercially off Alaska. The annual dockside value of Alaska king and tanner crab fisheries averaged about $\$ 195$ million during the $1978-90$ period $(61 \%$ or $\$ 118$ million for king crabs alone). Eighty-nine percent, or \$105 million of the value of king crab fisheries, was derived from the eastern Bering Sea and Aleutian Islands. About $75 \%$, or $\$ 88$ million of the value of king crab fisheries, came from red king crab landings. The average annual value of tanner crab landings during 1978-90 was $\$ 77$ million, with $\$ 58$ million or $76 \%$ coming from the Bering Sea-Aleutian Island area. King crab value peaked at $\$ 295$ million in 1980 , and tanner crab value peaked at $\$ 158$ million in 1990 .

About 250 vessels, mostly large and modern and each fishing an average of
300-350 pots, make up the Bering SeaAleutian Islands crab fleet. Over 400 vessels harvest crabs in the Gulf of Alaska, although there is considerable vessel overlap between the areas. Catches are restricted by quotas, seasons, and size and sex limits. Fishing seasons are set at times which avoid molting, mating, and softshell periods, both to protect crab resources and to improve product quality. Limits on the number of pots per vessel are in effect in most areas of the Gulf. Vessels are also restricted by the number of management areas they may fish in any given year. Vessels which both catch and process crabs are required to have observers throughout the season to monitor the catch and compliance with regulations.

Catch and abundance trends for king crabs fluctuated during 1960-90 (Fig. 201). After a 1964-66 peak, declines were evident. Until 1967, Japanese and Soviet

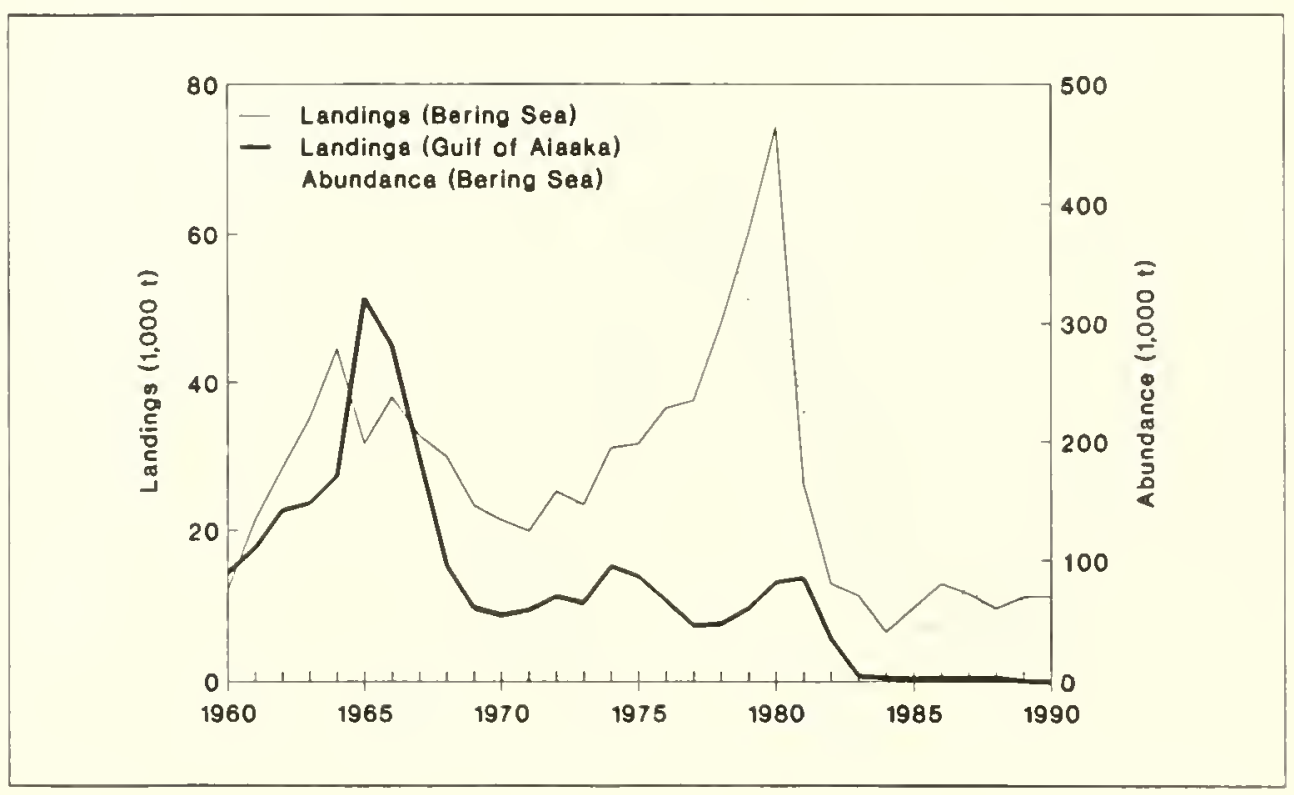




\section{... Crab}

Figure 20-2.-Tanner crab landings from the Bering Sea and Gulf of Alaska, 1960-90, and abundance of two species of tanner crab, 1976-90. fisheries dominated Bering Sea landings, but those fisheries were phased out during bilateral negotiations until foreign fishing ceased in 1974. During the late 1970's, domestic catches built to record levels in the Bering Sea, peaking at 74,000 $t$ in 1980 . Gulf catches varied at a relatively low level for a decade before dropping lower yet in 1983. Almost all Gulf of Alaska king crab fisheries have been closed since 1983. In the Bering Sea, catches dropped precipitously in 1981, followed by further declines to a low in 1983. Since then, there has been a gradual increase in the catch.

Bering Sea-Aleutian Islands tanner crab catches are largest in the eastern Bering Sea (Fig. 20-2). The $1965-75$ period was a developmental phase. During 1975-85, the catch peaked at about 49,000 tin 1979 and then declined. Since 1984, the catch has increased, reaching about $85,000 \mathrm{t}$ in 1990. Abundance trends for the eastern Bering Sea stocks indicate that the bairdi stock declined from a relatively high level in the late 1970's to a low in 1985. Since then, the Bering Sea bairdi stock has recovered and is currently approaching its former level. From a low in 1985, the opilio stock has rebounded sharply and is approaching an all-time high level. The catch in the Gulf of Alaska, composed exclusively of bairdi, reached peak levels during the 1970's, following a developmental phase in the late 1960's. Since 1979, the Gulf of Alaska catch has declined.

Values for RAY, CPY, and LTPY are presented in Table 20-1. Information on CPY and LTPY is lacking for both king and tanner crabs. Thus, default values for these parameters were derived by equating $C P Y$

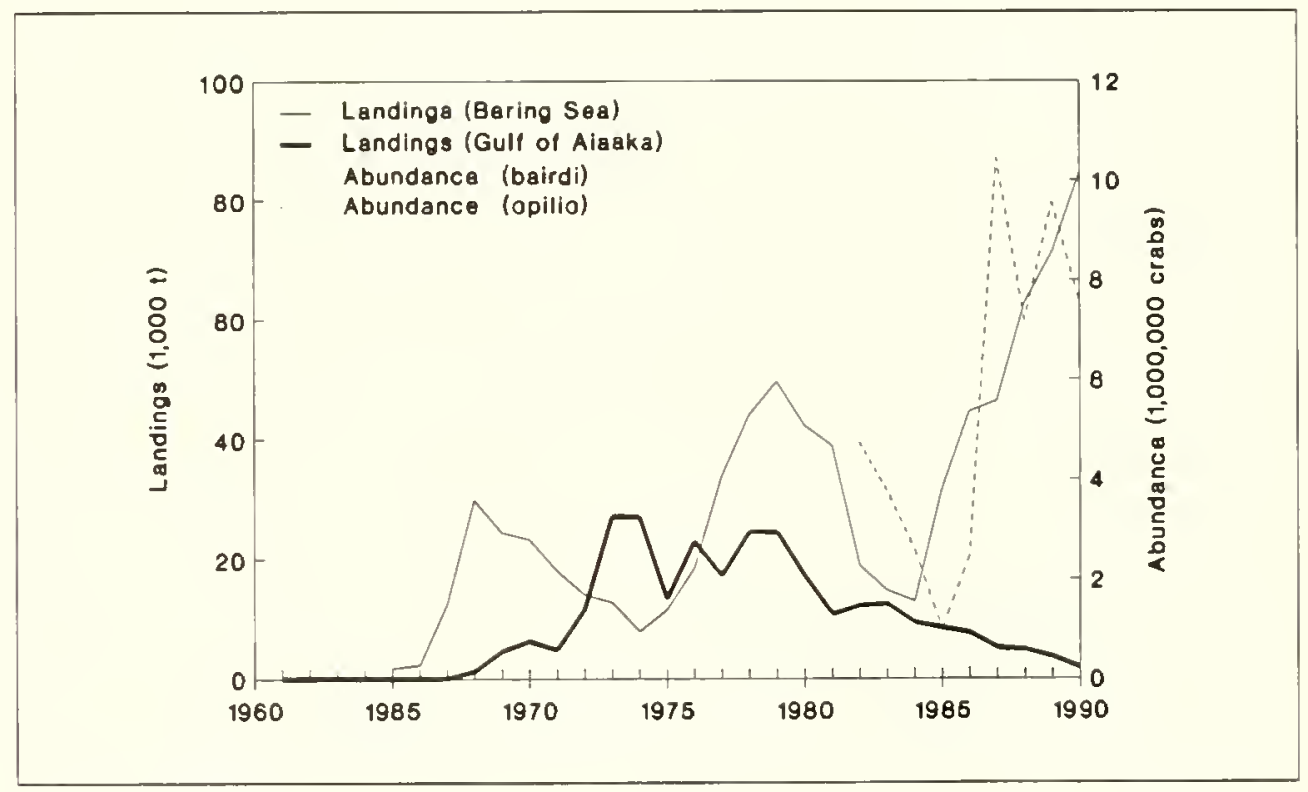

Table 20-1.-Recent average, current potential, and long-term potential yields in metric tons (t), and status of utilization for Alaska shellifish resources. The LTPY, CPY, and RAY for the unit equals the sum of the species' LTPY'S, CPY'S, and RAY'S.
Long-term potential yield $($ LTPY $)=\quad 104,934 \mathrm{t}$
Current potential yield (CPY) $=\quad 89,308 \mathrm{t}$
Recent average yield $(\text { RAY })^{1}=\quad 89,308 \mathrm{t}$

\begin{tabular}{|c|c|c|c|c|}
\hline \multirow[b]{2}{*}{ Species group } & \multicolumn{3}{|c|}{ Yield (t) } & \multirow{2}{*}{$\begin{array}{l}\text { Status of } \\
\text { utilization }\end{array}$} \\
\hline & RAY ${ }^{\prime}$ & CPY & LTPY & \\
\hline Tanner crabs & 76,256 & 76,256 & 45,436 & Full \\
\hline King crabs & 10,881 & 10,881 & 32,150 & Full \\
\hline Shrimp & 340 & 340 & 22,582 & Unknown \\
\hline Snails ${ }^{2}$ & 1,831 & 1,831 & 4,766 & Under \\
\hline
\end{tabular}

${ }^{1} 198890$ average.

${ }^{2}$ RAY and CPY dala $=1985.87$ average catch. LTPY data $=1971-87$ average. 
$\ldots$ Crab

and LTPY with the 1971-90 average catch Alaska crabs can be designated as fully utilized relative to yields of legal-sized males. Since female crabs are not landed it seems likely that most crab stocks could be designated as underutilized, in terms of existing fishing mortality on the reproductive stocks.

\section{shrimp and sea snail}

Figure 20-3.-Shrimp landings from the Bering Sea and Gulf of Alaska, 1960-89, and snail landings from the Bering Sea, 1972-87.
The U.S. fishery for shrimp in Alaska waters is at a low level. The western Gulf of Alaska has been the main area of operation. During the 1970's, when the fishery was more productive, $50-100$ vessels trawled for shrimp at Kodiak and along the Alaska Peninsula. Five species of shrimp contribute substantially to Alaskan landings, of which the northern pink shrimp is most important.

Shrimp landings in the Gulf of Alaska during 1960-90 (Fig. 20-3) show that catches rose steadily to about $58,000 \mathrm{t}$ in 1976 and then declined precipitously. Since 1988, negligible amounts of shrimp have been landed from western Alaska waters. During 1960-90, the dockside value of western shrimp fisheries averaged \$4 million annually and yielded a peak value of $\$ 14$ million in 1977 . Shrimp catches by the U.S.S.R. and Japan in the
Bering Sea peaked at $32,000 \mathrm{t}$ in 1963 , and gradually declined thereafter, until the fishery ended in 1973.

As with crabs, the potential yields of Alaska shrimp stocks are not well understood, and have been equated to recent catches. Shrimp are managed by regulating the catch levels according to the level of the stocks. In addition, spring "egg hatch" closures are used to protect breeding stocks.

The Japanese fishery for snails, conducted from about 1971 until ending in 1987 , reached a peak of some $13,000 \mathrm{t}$ in 1974. Catches averaged about $4,800 \mathrm{t}$ during 1971-87. The snail stocks of the Bering Sea are underutilized because they are currently not fished. RAY and CPY equal the 1985-87 average catch and LTPY equals the 1971-87 average.

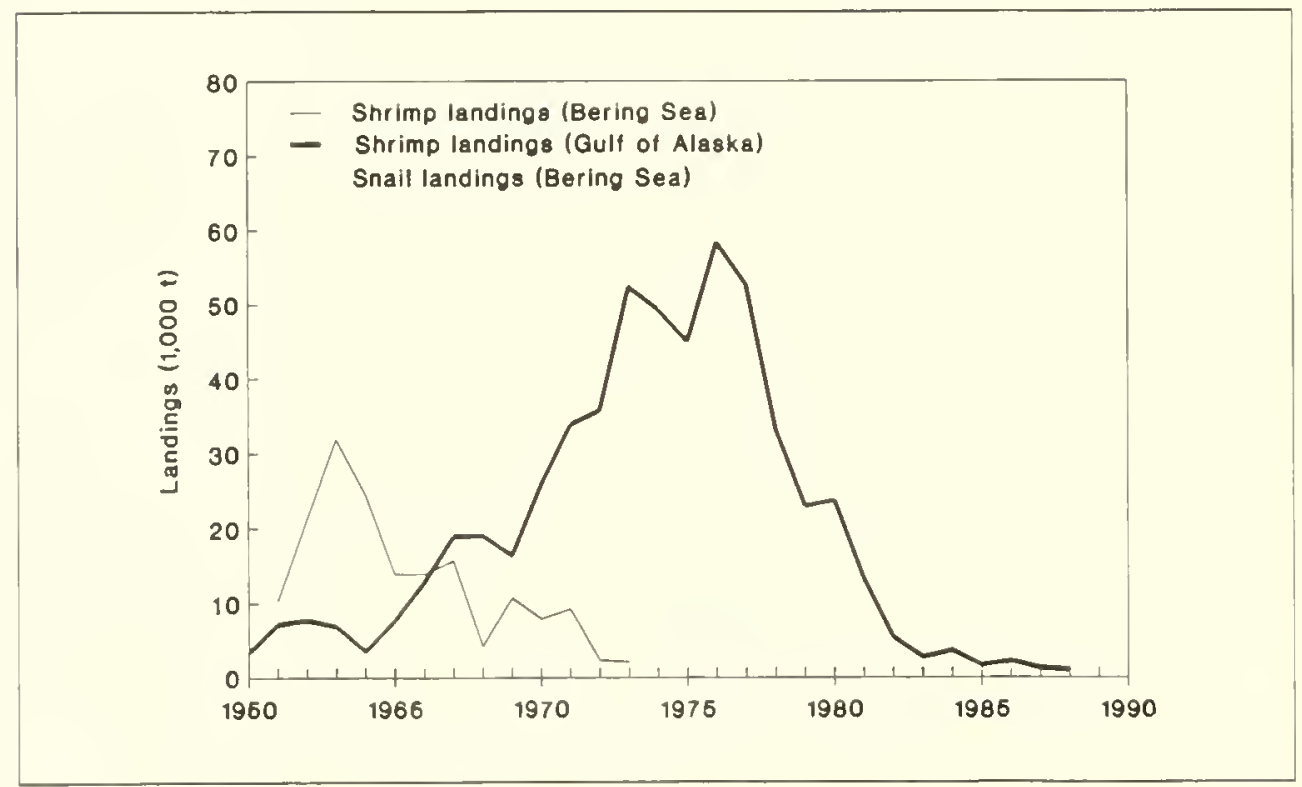


ISSUES

High Variability
These fisheries have been marked by major ups and downs in production (Fig. 20-1, 20-2, 20-3) and major perturbations in the shellfish industry. A management policy of maintaining catch stability has evolved, at least for crab stocks. Due to variable survival of young crabs, little can be done to stabilize fluctuations of the crab stocks themselves. Relatively low exploitation rates are used to stabilize the annual catch by holding over portions of strong incoming year classes to the next fishing season. This strategy has met with limited success. More effort should be placed on the problems of long-term prediction of population changes, of the effect of harvesting female crabs on population fluctuation, and of the effects of discard mortality in pot and trawl fisheries. More study is also required regarding the underlying reasons for shellfish population fluctuations, including relationships between predator (cod and pollock) and prey (shrimp) abundance. Other ecological conditions that lead to strong or weak year classes, such as those influencing larval survival, are also poorly understood.
Bycatch

Lack of Data
The bycatch of crabs in trawl and pot fisheries is also a major issue. Not only is bycatch an allocation problem, the unknown mortalities associated with trawl and pot gear discards of crabs could have a biological impact on crab stocks. When crab numbers are low, such bycatch mortalities, coupled with directed fishing mortality, could impose unacceptable risks to stock recovery.
Basic life history information, including growth rates, mortality rates, reproductive cycles, food habits, habitat requirements, and predator-prey relationships, is frequently lacking for Alaska shellfish stocks. This is particularly true of the underutilized resources such as mollusks, crangonid shrimps, octopuses, squids, sea urchins, and snails. For example, Bering Sea snail stocks represent a latent resource for which markets have existed in the past, but little is known of their numbers, productivity, or potential yield. 


\section{INTRODUCTION}

Table 21-1.- Recent average, current potential and long-term potential yields in metric tons (t), and status of utilization for nearshore fisheries resources. The LTPY, CPY, and RAY for the unit equals the sum of the species' LTPY's, CPY's, and RAY's. Where the species' LTPY is unknown, the species' CPY is substituted in the sum. If the species' CPY is unknown, the species' RAY is substituted.
Many U.S. coastal and estuarine species provide important recreational and commercial fisheries, but they are not Federally managed. This diverse (Init includes highly prized gamefishes like tarpon, bonefish, tautog, permit, and snook, as well as surfperches and Florida pompano. It also includes small fishes used for bait, food, or processing into oil and meal, such as mutlet, smelts, eulachon, ballyhoo, sardines, and herrings. Valuable invertebrates like the Dungeness, blue, rock, and Jonah crabs; Pacific shrimps, abalones, hard and softshell clams, bay scallops, oysters, periwinkles, and whelks (conchs) are also in this group.

For 1988-90, the average annual value of the commercial components of the species in Table 21-1 was about $\$ 376$ million. No separate values are available for the recreational fisheries but they are certainly significant, especially to many coastal economies.

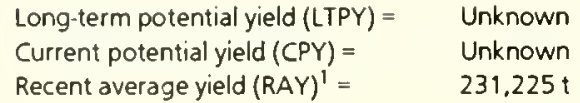

\begin{tabular}{|c|c|c|c|c|}
\hline \multirow[b]{2}{*}{ Species } & \multicolumn{3}{|c|}{ Yield (t) } & \multirow{2}{*}{$\begin{array}{c}\text { Status of } \\
\text { utilization }\end{array}$} \\
\hline & RAY $^{\prime}$ & CPY & LTPY & \\
\hline Blue crab & $95,593^{2}$ & Unknown & Unknown & Full \\
\hline Pacific shrimp & $32,180^{2}$ & Unknown & Unknown & Full \\
\hline Sea urchins (Pacific) & $25,215^{2}$ & Unknown & Unknown & Unknown \\
\hline Dungeness crab & $18,119^{2}$ & Unknown & Unknown & Full \\
\hline Mullets & $14,342^{2}$ & Unknown & Unknown & Unknown \\
\hline Oyster (Atlantic) & $9,875^{2}$ & Unknown & Unknown & Over \\
\hline Sea urchins (Atlantic) & $4,392^{2}$ & Unknown & Unknown & Unknown \\
\hline Atlantic hard clams & $4,283^{2}$ & Unknown & Unknown & Over \\
\hline Blue mussel & $4,090^{2}$ & Unknown & Unknown & Unknown \\
\hline Oyster (Pacific) & $4.026^{2}$ & Unknown & Unknown & Unknown \\
\hline Softshell clam & $3.096^{2}$ & Unknown & Unknown & Full \\
\hline Atlantic thread herring & 3.054 & Unknown & Unknown & Unknown \\
\hline Calico scallop & $2,961^{2}$ & Unknown & Unknown & Full \\
\hline Ladyfish & 2,036 & Unknown & Unknown & Unknown \\
\hline Other shads, herrings & 1.960 & Unknown & Unknown & Unknown \\
\hline Eulachon & $1.312^{2}$ & Unknown & Unknown & Unknown \\
\hline Spanish sardine & 1.296 & Unknown & Unknown & Unknown \\
\hline American eel & 551 & Unknown & Unknown & Unknown \\
\hline Pacific hard clams & $461^{2}$ & Unknown & Unknown & Full \\
\hline Ballyhoo & $446^{2}$ & Unknown & Unknown & Unknown \\
\hline Tautog & 411 & Unknown & Unknown & Unknown \\
\hline Surfperches & 392 & Unknown & Unknown & Unknown \\
\hline Florida pompano & 316 & Unknown & Unknown & Unknown \\
\hline Surf smelt & 239 & Unknown & Unknown & Unknown \\
\hline Bay scallop & $209^{2}$ & Unknown & Unknown & Over \\
\hline Abalones & $202^{2}$ & Unknown & Unknown & Over \\
\hline Snook & $140^{3}$ & Unknown & Unknown & Over \\
\hline Permit & $18^{3}$ & Unknown & Unknown & Unknown \\
\hline California corvina & $10^{3}$ & Unknown & Unknown & Unknown \\
\hline Tarpon & Unknown ${ }^{4}$ & Unknown & Unknown & Unknown \\
\hline Bonefish & Unknown ${ }^{4}$ & Unknown & Unknown & Unknown \\
\hline Striped bass (Pacific) & Unknown ${ }^{4}$ & Unknown & Unknown & Over \\
\hline Pacific razor clam & Unknown ${ }^{5}$ & Unknown & Unknown & Over \\
\hline Pismo clam & Unknown $^{5}$ & Unknown & Unknown & Over \\
\hline
\end{tabular}

198890 average

${ }^{2}$ Cornmercial landings only

${ }^{3}$ Recrealtonal landings only

${ }^{4}$ Nol avallable or meaningful owing to calch and-release nature of fishery or relatively infrequent landings.

${ }^{5}$ Nol avallable. 
SPECIES AND RANGE
Most species in this group (Table 21-1) live near shore during much or all of their lives. Some, like the shads, herrings, smelts, and Pacific striped bass, are anadromous, ascending fresh water to spawn but spending their adult lives in estuaries or at sea. In contrast, the American eel lives much of its life in fresh or brackish water but migrates far offshore to spawn in the Sargasso Sea (deep North Atlantic, beyond the Gulf Stream).

These species are distributed widely. Bay scallops, hard and softshell clarns, rock and Jonah crabs, periwinkles, and whelks are among the important fishery resources of the northeastern United States. Shads, herrings, sardines, mullets, Florida pompano, and calico scallops are fished pri- marily along the middle and southern U.S. Atlantic coast and in the Gulf of Mexico. Many of the game fishes are particularly valuable to the Florida economy, while invertebrates, like the blue crab and Atlantic oyster, support major fisheries from the Gulf to Chesapeake Bay.

Corvina and striped bass are important sport fishes in California waters, while surfperches are fished along much of the U.S. west coast. Other species like abalones, clams (hard, Pismo, razor), eulachon, and surf smelt support both recreational and commercial west coast fisheries. In the Pacific Northwest and southern Alaska, Dungeness crabs, Pacific oysters, and Pacific shrimps support valuable commercial fisheries.

\section{FISHERIES}

Bonefish, tarpon, snook, and permit are sought primarily by sport fishermen who often employ professional guides. Other popular recreational fishes, such as the surfperches and tautog, are caught primarily by anglers using bait from the beach or small boats. The small baitfishes and food fishes are harvested by both recreational and commercial fishermen using cast nets, gill nets, seines, dip nets, and pound nets; the southern Florida ballyhoo fishery supplies bait to the charterboat industry.

Many methods are also used to harvest the invertebrate species. Commercial and sport divers gather abalones, particularly in southern and central California; fishermen in small boats dive, dredge, and tong for oysters and rake hard clams; recreational clammers dig Pismo clams on sandy beaches in central California and razor clams in the Pacific Northwest; trawlers and divers take sea urchins off the New England and northern Pacific coasts; and commercial and recreational crabbers fish with pots, traps, trotlines, dredges, and dip nets for blue, rock, and Jonah crabs on the Atlantic coast and for Dungeness crabs on the Pacific coast. Pacific shrimps are harvested with pots and trawls. Other species, such as blue mussels, are both cultured and harvested from the wild.

The number of participants in these nearshore fisheries is difficult to assess because of their diversity. There is no doubt, however, that millions of recreational and commercial fishermen seek these resources; there are, for example, an estimated $600,000+$ recreational razor clam diggers in Washington alone.

In general, landings for many of these species have declined in recent years (Fig. 21-1, 21-2, 21-3, 21-4). Atlantic hard clam, softshell clam, bay scallop, and abalone landings were substantially lower in the 1980 's than in the previous three decades. Atlantic oyster landings fell sharply in the late 1980's, and Chesapeake Bay stocks are considered severely depleted. After peaking in the 1970's, Pacific shrimp landings fell off in the 1980's, primarily because of reduced Alaska landings. Dungeness and blue crab landings, though cyclical, appear to have withstood harvesting pressures well through the 40-year period examined.

Because these species frequent nearshore waters, they are not included in Federal fishery management plans; some are managed under regional, state, and/or local authority. Typically, size limits are used to protect molluscan and crustacean resources from overutilization, whereas gear restrictions are the most common management measures used for the finfishes in this group. Area closures, bag limits, and calch quotas are also employed, particularly for shellfish. Interstate Fishery Management Commission plans 
Figure 21-1.-Commercial landings of hard and softshell clams and bay scallops from the southeastern U.S. coast, 1950-90.
Figure 21-2.-Commercial abalone landings from the U.S. Pacific coast, 1950-90.
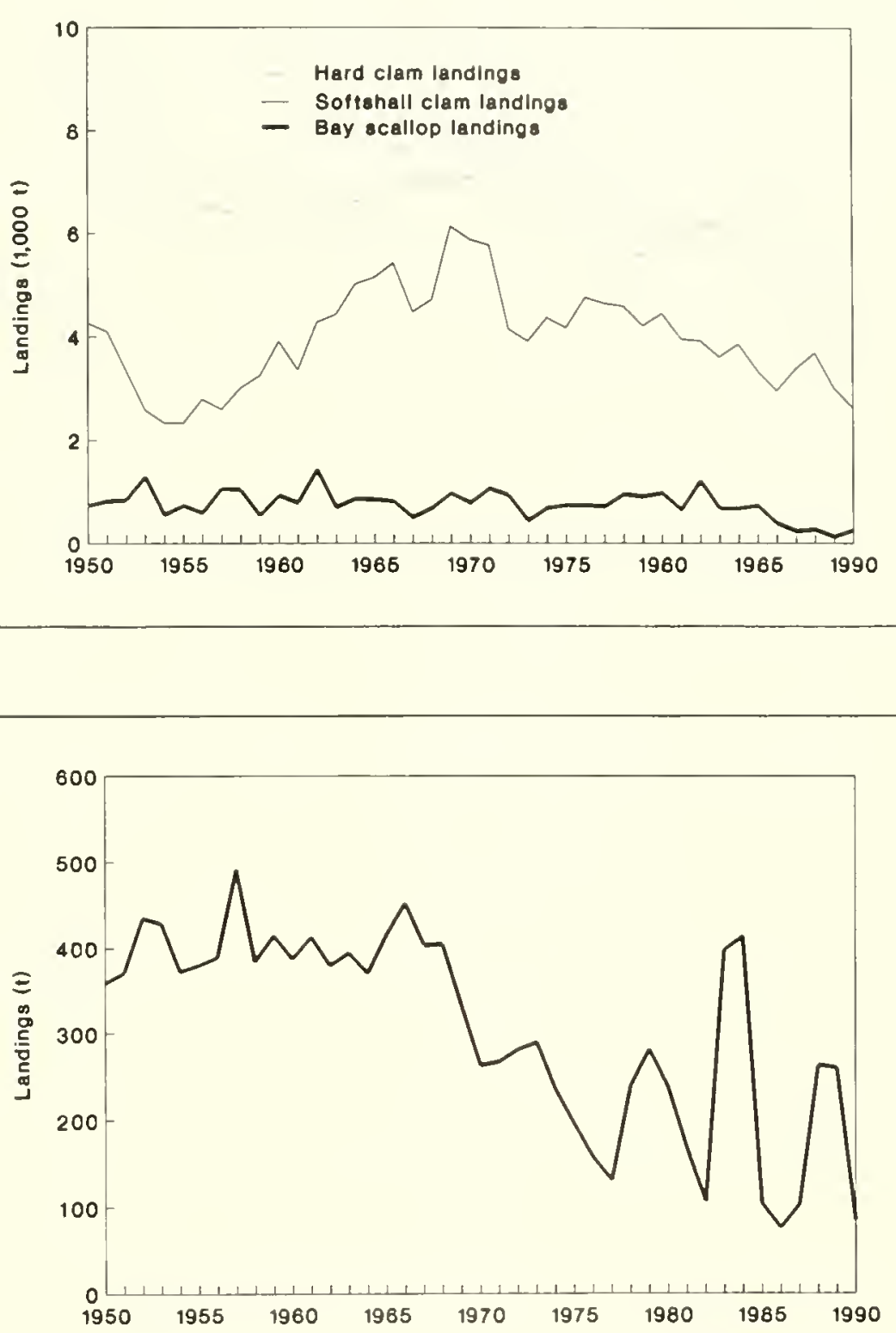

.. FISHERIES have been developed for such Chesapeake Bay species as the oyster and blue crab to try to achieva consistent management between states. Some states, notably Florida and California, have prohibited all commercial harvest of certain species by designating them as gamefishes.
It is difficult to assess the status of these stocks throughout their ranges because they are under varied management and data collection systems. Many of the species in Table 21-1 are probably overexploited, at least in part of their ranges, as with the Chesapeake Bay oyster. Others, like many of the herrings, are difficult to assess because the data on abundance and stock structure are sparse, dispersed, or nonexistent. 
Figure 21-3.-Commercial blue crab and oyster landings from the southeastern U.S. coast, 1950-90.
Figure 21-4.-Commercial Dungeness crab and Pacific shrimp landings from oregon, California, and Washington, 1950-90.
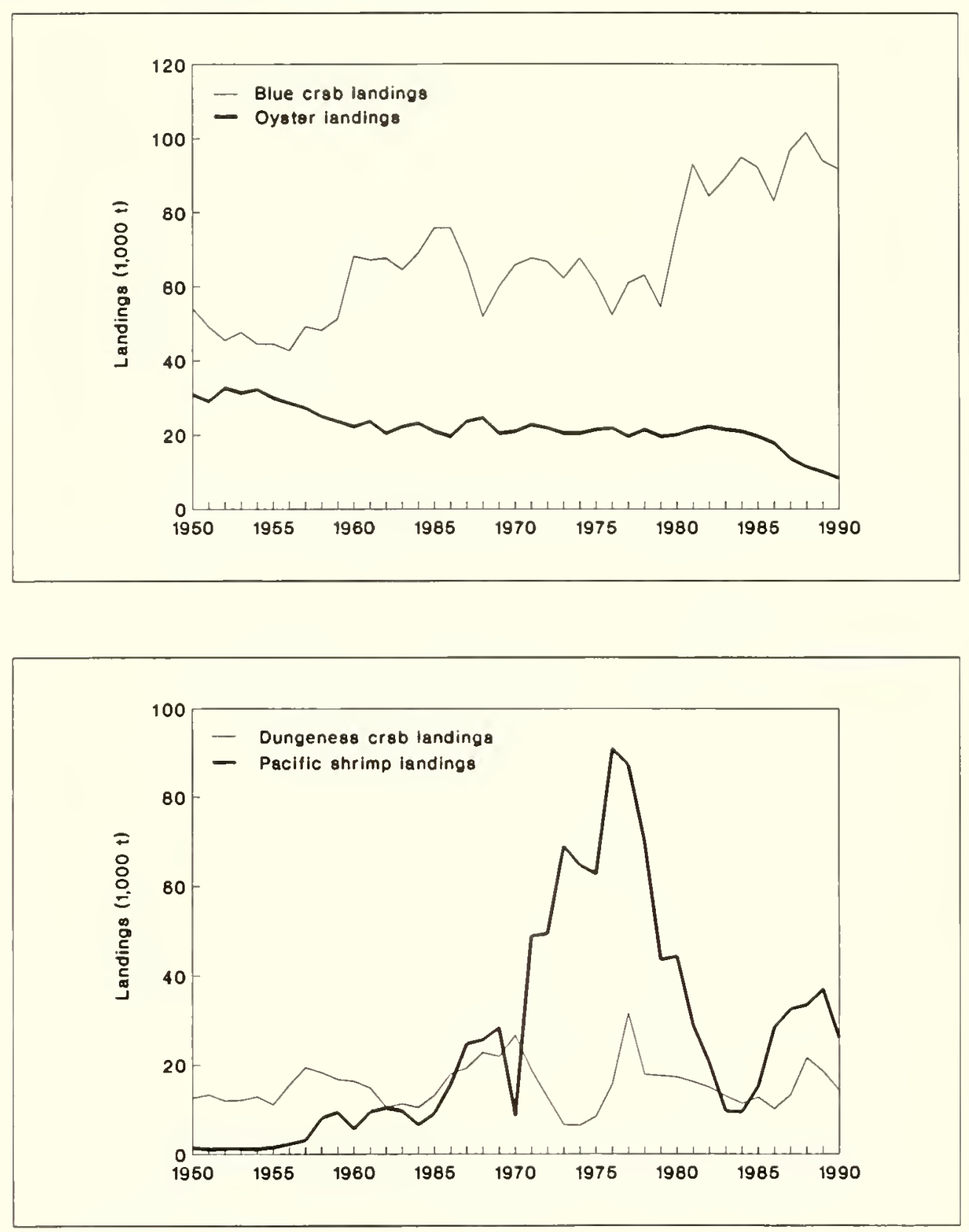

The recent annual yield of the species in this unit is conservatively estimated at more than 231,000 t. Table 21-1 presents the best data available, though the yields are probably low for many species because separate landings data are not always re ported (many of the baitfishes are lumped into other categories, for example). Furthermore, data on sport catches are not available for many of these species, particularly the invertebrates. Recreational as- pects of some of these fisheries are very large; Chesapeake Bay sport crabbers alone caught an estimated 19,000 t of blue crabs in 1983 and $9,800 \mathrm{t}$ in 1988 , or $44 \%$ and $32.1 \%$ of the total harvests, respectively. Some species, such as tarpon and bonefish, are sought primarily for sport and usually released alive; consequently, few or no landings data for them are reported even though they provide significant local and regional economic benefits. 


\section{ISSUES}

Because of their reliance on nearshore habitats (i.e., estuaries, reefs, mangroves, etc.) species in this group are particularly susceptible to habitat loss, pollution, changes in freshwater flows, siltation, and other environmental problems. Pacific striped bass have been hurt by habitat degradation and salinity changes in the San Francisco Bay estuary; Chesapeake Bay species, such as river herrings and hickory shad, have declined drastically in recent years; and Atlantic coast and Gulf of Mexico oyster and hard clam harvests have been severely reduced by pollution, disease, salinity changes, and habitat losses. Louisiana alone loses an estimated 35,200 acres of coastal wetlands habitat each year.

Because many shellfish fisheries are close to large population areas, the likelihood of pollution problems is high; fishing closures due to shellfish bed contamination cause large economic losses each year. In addition to direct pollution impacts, excessive nutrient loads may increase toxic plankton blooms that cause red tides and paralytic shellfish poisoning. Environmental stresses also make fish more susceptible to diseases and parasites, either killing them outright or making them difficult or impossible to market.

Overutilization has been at least partially responsible for depleting such species as Pacific razor clams, Pismo clams, abalones, oysters, Pacific shrimp, and snook. Marine mammals also feed on some of these species and may compete with fishermen; for example, sea otters on the $\mathrm{Pa}$ cific coast have depleted abalone and sea urchin stocks, particularly in California. 


\section{INTRODUCTION}

Marine mammals are managed under the Marine Mammal Protection Act (MMPA) of 1972 and the Endangered Species Act (ESA) of 1973. Other responsibilities are addressed in the Magnuson Fishery Conservation and Management Act (MFCMA)

\section{SPECIES AND STATUS}

Thirty-six species of marine mammals range the U.S. Atlantic and Gulf of Mexico waters (34 whales, dolphins, and porpoises, and 2 seal species). Their status is poorly known, but some, like the right whale, Mid-Atlantic coastal bottlenose dolphin, and harbor porpoise, are under stresses that may affect their survival. of 1976, which extends the jurisdiction of the MMPA throughout the U.S. EEZ, and the Whale Conservation Act of 1976, which was intended to further aid the recovery of whales.

Table 22-1 shows what is (and is not) known about the status and trends of several Atlantic marine mammals. Brief summaries below for selected species give additional data on distribution, current and historical abundance, and population trends.
Table 22-1.-Stock assessments of selected marine mammals in U.S. waters of the North Atlantic ocean.

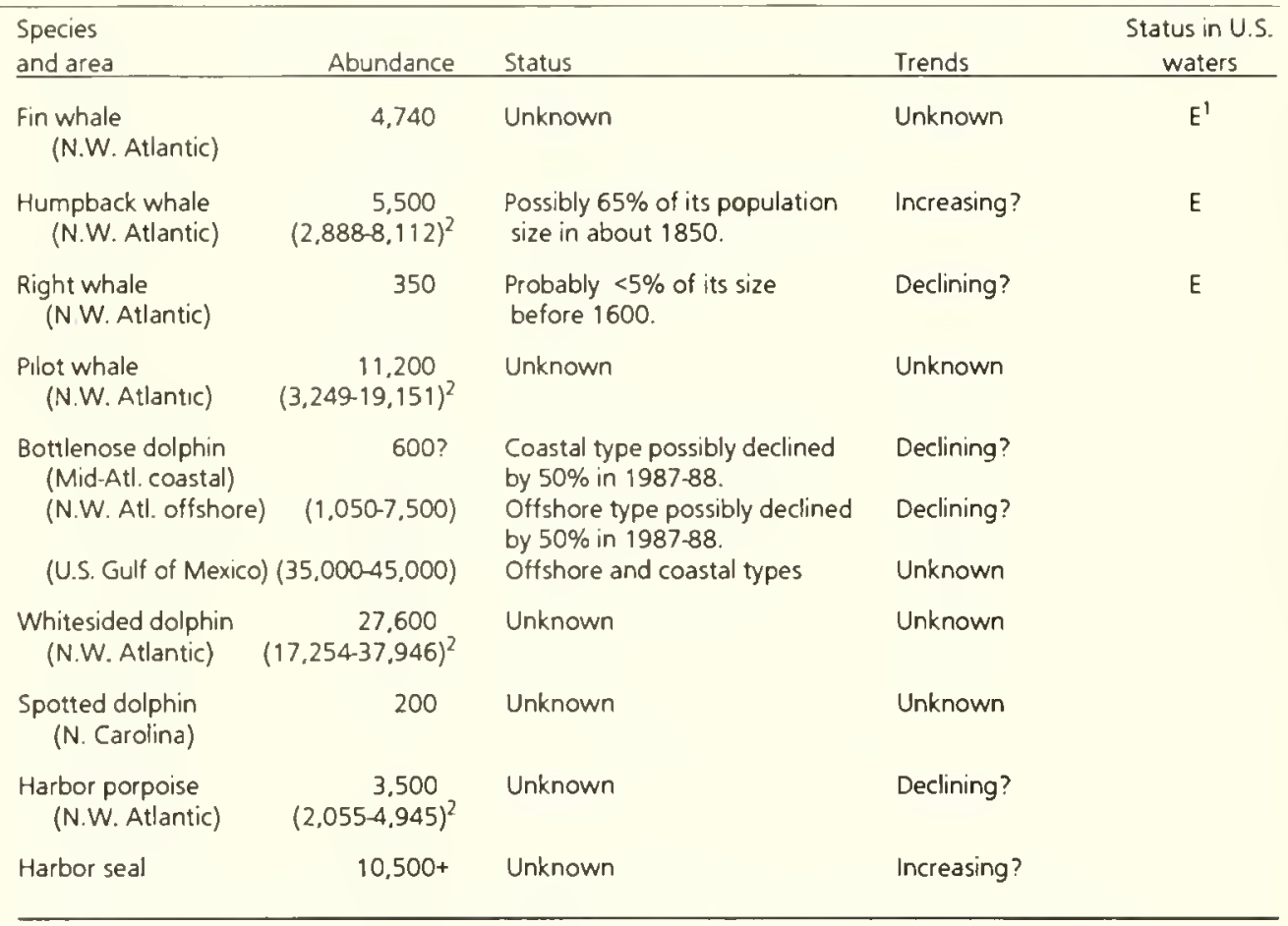

${ }^{\prime} E=$ Listed as endangered under the Endangered Species ACt

${ }^{2} 95 \%$ confidence interval

\section{Bottlenose Dolphin}

The number of stocks of bottlenose dolphins is unknown, although there appear to be offshore and coastal types, possibly forming two distinct populations. There are no comprehensive population estimates, but abundance in the Gulf of Mexico is $35,000-45,000$ in waters of $100 \mathrm{fm}$ or less. Nearshore aerial surveys between Cape
Hatteras and Nova Scotia in 197981 suggest that summer abundance was 4,30012,900 . However, a large die-off of bottlenose dolphins in 1987-88 may have resulted in a $50 \%$ or greater decline in the nearshore and offshore types. An offshore survey from New Jersey to Cape Hatteras in 1987 found about 1,050-7,500. 
Pilot Whales
There are two species of pilot whales in the western North Atlantic Ocean: Globicephala melas ranges from Iceland to North Carolina, and G. macrorhynchus ranges from Virginia to Venezuela. Pilot whales concentrate along the continental shelf edge of the Mid-Atlantic and southern
New England during midwinter and early spring, then move onto the shelf in late spring where they are widely distributed until autumn. Stock structure and abundance are unknown. Aerial surveys off the U.S. northeast coast in 1979-81 resulted in a rough estimate of 11,200 pilot whales.

\section{Fin Whale}

Fin whales, listed as endangered under the ESA, range widely and are probably the most numerous large cetacean in temperate waters of the western North Atlantic Ocean. They range throughout the continental shelf in all seasons, but most sight- ings are from off Cape Cod to the southwest Gulf of Maine. Stock structure and total abundance are unknown. An estimate of abundance off the northeast coast in $1979-81$ was 4,740 whales.

\section{Humpback Whale}

Also listed as endangered, the humpback whale has four or five stocks which summer in the Gulf of Maine, Gulf of St. Lawrence, and the waters of Newfoundland-Labrador, west Greenland, and possibly Iceland. Along the northeast coast, humpbacks frequent the Great South Channel, Georges Bank, Stellwagen Bank, and Jeffery's Ledge. The estimated total population is about 5,505 whales. A minimum estimate of the population prior to commercial whaling (about 1865) was 4,400-4,700 humpbacks. The Gulf of Maine hosted about 240 humpbacks in summer 1986 , the only group that summers exclusively in U.S. waters.

\section{Right whale}

Endangered right whales also frequent the continental shelf from Florida to Nova Scotia from spring to autumn. Winter distribution is not well known but may be offshore. The population is estimated at no more than 350 animals and may be declining. The pre-18th century population may have been as high as 10,000 and, if so, the current population is more than $95 \%$ depleted.

\section{Harbor Porpoise}

The harbor porpoise ranges from Maine to North Carolina-occasionally to Floridaand may constitute a single population. Summer and early autumn distribution is in the Bay of Fundy and northern Gulf of
Maine, and by late autumn some animals move southwest to winter in southern New England and Mid-Atlantic waters. Spring abundance estimates for a portion of the range was 3,541 . 
Three issues of particular concern are: 1) Have fisheries interactions and other human-related activities significantly altered the carrying capacity of the marine ecosystem or directly affected marine mammal populations, 2) are the depleted
Information on the incidental take of marine mammals in commercial fisheries is incomplete; a fishery-wide observer program was started in 1989, however. Besides the potential impacts of incidental marine mammal take, an assessment of the effect of fisheries and other human activities on the ecosystem is a critical long-term concern that requires more research. Meeting the 1988 amendments to the MMPA is an important first step in that process.

Bottlenose dolphins in the Gulf of Mexico are captured alive for use at public displays; additional animals are lost to commercial fishing operations and illegal shooting. The number of these losses is poorly known, though estimates run to more than $1 \%$ of the stock yearly. Pilot whales are sometimes killed in foreign and U.S. mackerel and swordfish drift gillnet fisheries off New England. Some whitesided dolphins, bottlenose dolphins, striped dolphins, and beaked whales may also be killed in these fisheries. The impact of this loss is unknown, but much of it has recently included pregnant and nursing females. marine mammal species recovering and have appropriate measures been taken to facilitate recovery, and 3 ) what is the significance of the recent mass strandings of marine mammals?

The incidental take of harbor porpoise in the Gulf of Maine groundfish gillnet fishery was estimated at 60-1,000 per year over the past decade; the larger takes probably have a significant impact on the population. Canadian studies found that incidental takes caused a shift toward smaller and younger animals in the population.

Direct interactions between fin whales and commercial fisheries are infrequent and usually not fatal. Recent studies suggest, however, that fin whales often feed on commercially valuable pelagic fishes. Humpback whales have been caught in a wide variety of fishing gear. From 1975 to 1990,51 humpbacks were reported entangled $(20-25 \%$ died, though most were released alive). Another 450 humpbacks became entangled in gear in Canadian waters during the same time period. Harbor seals are incidentally taken in several Gulf of Maine fisheries, particularly in groundfish gill nets, but the impact of the take is not known. Current levels of such losses are probably small. Harbor seals also steal lobster pot bait and eat penraised salmon.
Recovery of Protected Species
Six U.S. Atlantic coast marine mammals are listed as endangered under the ESA. Although data are incomplete, only the right whale appears at such a critically low level that its long-term survival is in question. A significant number of stranded right whales $(20 \%)$ show major injuries from large-vessel collisions. Young right whales seem particularly vulnerable. A loss of just 2-3 calves per year, for example, would equal about $10 \%$ or more of their annual production. Data needed for a comprehensive recovery and conservation plan include population trends, life history, and habitat requirements. Far too little data for the blue whale and other species exist to judge whether they are recovering or what other management actions are warranted. 
...strandings population of bottlenose dolphin may have died from causes related to a natural marine biotoxin. Increased strandings also occurred in the Gulf of Mexico in 1989-90 for unknown reasons. Fourteen humpback whales also apparently died of a "red tide" toxin near Cape Cod in late 1987, and seven other young humpbacks stranded and died for unknown reasons.

Some 350 harbor seals died from phocine influenza-A virus in 1980. Although the population has since recovered, these east coast harbor seals may be as vulnerable to viral disease as were the harbor seals that died by the thousands in northern European waters in recent years. 


\section{INTRODUCTION}

Marine mammals are managed under the Marine Mammal Protection Act (MMPA) of 1972 and the Endangered Species Act (ESA) of 1973. Other responsibilities are addressed in the Magnuson Fishery Conservation and Managernent Act (MFCMA) of 1976, which extends the jurisdiction of the MMPA throughout the U.S. EEZ, and the Whale Conservation Act of 1976, which was intended to further aid the recovery of whales.

\section{SPECIES AND STATUS}

Forty-two species of marine mammals occur in U.S. Pacific waters (31 whales, dolphins, and porpoises, and 11 species of seals and sea lions). Fourteen are commonly seen along the coast (gray whale, bottlenose dolphin, harbor seal, and others), whereas the 28 others frequent offshore or remote island waters (beaked whales, ribbon seal, Hawaiian monk seal, and others), or are severely reduced in numbers and thus seldom seen (blue whale, right whale, Guadalupe fur seal, for example).

Table 23-1 shows what is (and is not) known about the status and trends of several Pacific marine mammals. Brief summaries below for selected species give additional data on distribution, current and historical abundance, and population trends.
Table 23-1.-Stock assessments of selected marine mammals in U.S. North Pacific Ocean waters.

\begin{tabular}{|c|c|c|c|c|}
\hline $\begin{array}{l}\text { Species } \\
\text { and area }\end{array}$ & Abundance & Status & $\begin{array}{r}\text { Statu } \\
w\end{array}$ & $\begin{array}{l}\text { tus in U.S. } \\
\text { waters }\end{array}$ \\
\hline $\begin{array}{l}\text { Bowhead whale } \\
\text { (W. Arctic) }\end{array}$ & $\begin{array}{c}7.500 \\
.400-9.200)^{\prime}\end{array}$ & $\begin{array}{l}\text { Current population size } \\
\text { is } 40.9 \%(38.0-42.0 \%) \\
\text { of the } 1848 \text { population size. }\end{array}$ & $\begin{array}{l}\text { Increasing at } 3.1 \% \\
(0.1-6.2 \%) / \text { year, } \\
1978-88\end{array}$ & $E^{2}$ \\
\hline $\begin{array}{l}\text { Gray whale } \\
\text { (N.E. Pacific) }\end{array}$ & $\begin{array}{c}21,113 \\
737-22,489)^{\prime}\end{array}$ & $\begin{array}{l}\text { Fully recovered and now equal } \\
\text { or more abundant than } \\
\text { known since } 1846 \text {. }\end{array}$ & $\begin{array}{l}\text { Increasing at } 3.2 \% \\
(2.3-4.2 \%) / \text { year } \\
\text { since } 1968\end{array}$ & $E$ \\
\hline $\begin{array}{l}\text { Humpback whale } \\
\text { (E. Pacific) }\end{array}$ & $, 398-2,040$ & $\begin{array}{l}\text { Probably less than } 15 \% \text { of } \\
\text { abundance prior to } 1850 \text {. }\end{array}$ & Unknown & E \\
\hline $\begin{array}{l}\text { Harbor porpoise } \\
\text { (Washington/Oregon) }\end{array}$ & $35,000 ?$ & Unknown & Unknown & \\
\hline Hawaiian monk seal & 1,500 & $\begin{array}{l}\text { Unknown. Small remnant, } \\
\text { monotypic species. }\end{array}$ & $\begin{array}{l}\text { Unknown. Pup } \\
\text { counts declining. }\end{array}$ & E \\
\hline $\begin{array}{l}\text { Northern fur seal } \\
\text { (Pribilof Islands) }\end{array}$ & 871,000 & $\begin{array}{l}\text { Current level is }<40 \% \text { of the } \\
\text { population in the mid-1950's. }\end{array}$ & $\begin{array}{l}\text { No significant trend } \\
\text { since } 1983 \text { on St. Paul; } \\
\text { declining at } 6 \% / \text { year } \\
\text { on St. George. }\end{array}$ & $D^{3}$ \\
\hline $\begin{array}{l}\text { Steller sea lion } \\
\text { (N Pacific) }\end{array}$ & 42,000 & $\begin{array}{l}\text { Currently } 22 \% \text { of size } \\
\text { in the late } 1950^{\circ} \mathrm{s} \text {. }\end{array}$ & $\begin{array}{l}\text { Declining at } 4.2 \% / \text { year. } \\
1960-90 \text {. }\end{array}$ & $T^{4}$ \\
\hline $\begin{array}{l}\text { California sea lion } \\
\text { (California-Washington) }\end{array}$ & 87,000 & $\begin{array}{l}\text { Unknown, but believed to } \\
\text { be at or above the level of } \\
\text { maximum net production. }\end{array}$ & $\begin{array}{l}\text { Increasing at } 6 \% / \text { year. } \\
1975-86\end{array}$ & \\
\hline $\begin{array}{l}\text { Harbor seal } \\
\quad \text { (California-Washington) }\end{array}$ & 42,000 & Unknown & Increasing? & \\
\hline \multicolumn{5}{|l|}{ ETP Dolphins } \\
\hline N. offshore spotted & 658,300 & Unknown & \multicolumn{2}{|l|}{$\begin{array}{l}\text { Declining (1986-90) } \\
\text { based on preliminary } \\
\text { analyses of observer data. }\end{array}$} \\
\hline S. offshore spotted & 87,700 & Unknown & \multicolumn{2}{|l|}{ Unknown } \\
\hline E. spinner & 391,200 & Unknown & \multicolumn{2}{|l|}{$\begin{array}{l}\text { Stable ( } 1986-90) \text { based } \\
\text { on analysis of observer } \\
\text { data. }\end{array}$} \\
\hline Whitebelly spinner & 363,300 & Unknown & \multicolumn{2}{|l|}{ Unknown } \\
\hline N. common & 177,700 & Unknown & \multicolumn{2}{|l|}{ Unknown } \\
\hline Cent. common & 568,000 & Unknown & \multicolumn{2}{|l|}{ Unknown } \\
\hline S. common & $1,657,500$ & Unknown & \multicolumn{2}{|l|}{ Unknown } \\
\hline N. striped & 111,600 & Unknown & \multicolumn{2}{|l|}{ Unknown } \\
\hline S. striped & $1,115,600$ & Unknown & \multicolumn{2}{|l|}{ Unknown } \\
\hline
\end{tabular}


Eastern Tropical Pacific (ETP) Dolphins
At least four species (13 stocks) of dolphins are incidentally taken in the international fishery for yellowfin tuna in the tropical Pacific waters off Mexico and Central America (about 57,000 were killed in 1990). Because those four species also occur in U.S. waters, and because the United States is the major market for the fishery, the NMFS has assessed the dolphin populations.

The northern stock of spotted dolphins is estimated at 658,300-2,205,500 and the southern stock at 85,800-451,900 (198689). Dolphin sightings suggest that both stocks have declined. Eastern spinner dolphins number 391,200-754,200, while whitebelly spinner dolphin stocks number about $363,300-1,398,400$. The data are too variable to determine population trends. Common dolphin abundance for the northern, central, and southern stocks were about 177,700, 568,000, and 1,657,500, respectively. Differences in yearly estimates suggest that 1) variances are underestimated, 2) immigration is extensive, or 3) annual calf production or mortality may vary greatly. Estimates of striped dolphin abundance is 652,000-2,251,300.

\section{Harbo: Porpoise}

Harbor porpoises range throughout North American coastal waters. Surveys of them have been conducted off California since 1984, periodically off Oregon and Washington, and not at all off Alaska. Harbor porpoises tend to concentrate at the mouth of the Columbia River and at many other bays. Estimates of abundance are 11,100 in California (3,274 in central California alone which is $30-97 \%$ of the carrying capacity). About 700-1,000 range Washington's north coast. The species was once abundant in Washington's inland waters but is rare there now.

\section{Bowhead Whale}

The endangered bowhead whale has ranged as far as the polar ice fields of the Northern Hemisphere. Total prewhaling abundance exceeded 120,000 , but by 1900 it was probably in the low thousands. In the U.S. western Arctic, 18,650 bowheads were killed by Yankee whalers between 1848 and 1914 from a population estimated at less than 20,000. The take by Alaska Eskimos has averaged 20-40 whales per year since 1914. The present population, 7,500 , is about $40-60 \%$ of its 1848 carrying capacity. The stock has been increasing since commercial whaling ended and has increased $3.1 \% /$ year since 1978 (Fig. 23-1).

\section{Gray Whale}

Still listed under ESA as endangered are the two stocks of North Pacific gray whales. The eastern North Pacific or "California" stock was heavily exploited by Yankee whalers in the last half of the 19th century. The present stock size, 21,113 , is equal to or larger than the size of the 1846 population of $15,000-20,000$. Population growth rate is $3.2 \%$ /year despite a Soviet subsistence catch of 167 whales per year (Fig. 23-2).

\section{Humpback Whale}

The endangered humpbacks in the eastern North Pacific Ocean migrate between the subtropical waters of Hawaii and coastal Mexico during the calving season and the temperate and subarctic waters of northern California and Alaska where they feed.
The population is estimated at 1,3002,000 . Prewhaling numbers (ca. 1850) were about 15,000 , but this may have included humpbacks from the western North Pacific Ocean. No information exists on population trends. 
Figure 23-1.-Actual count of bowhead whales, 1978-88.
Figure 23-2.-Estimated population of gray whales, 1965-90.
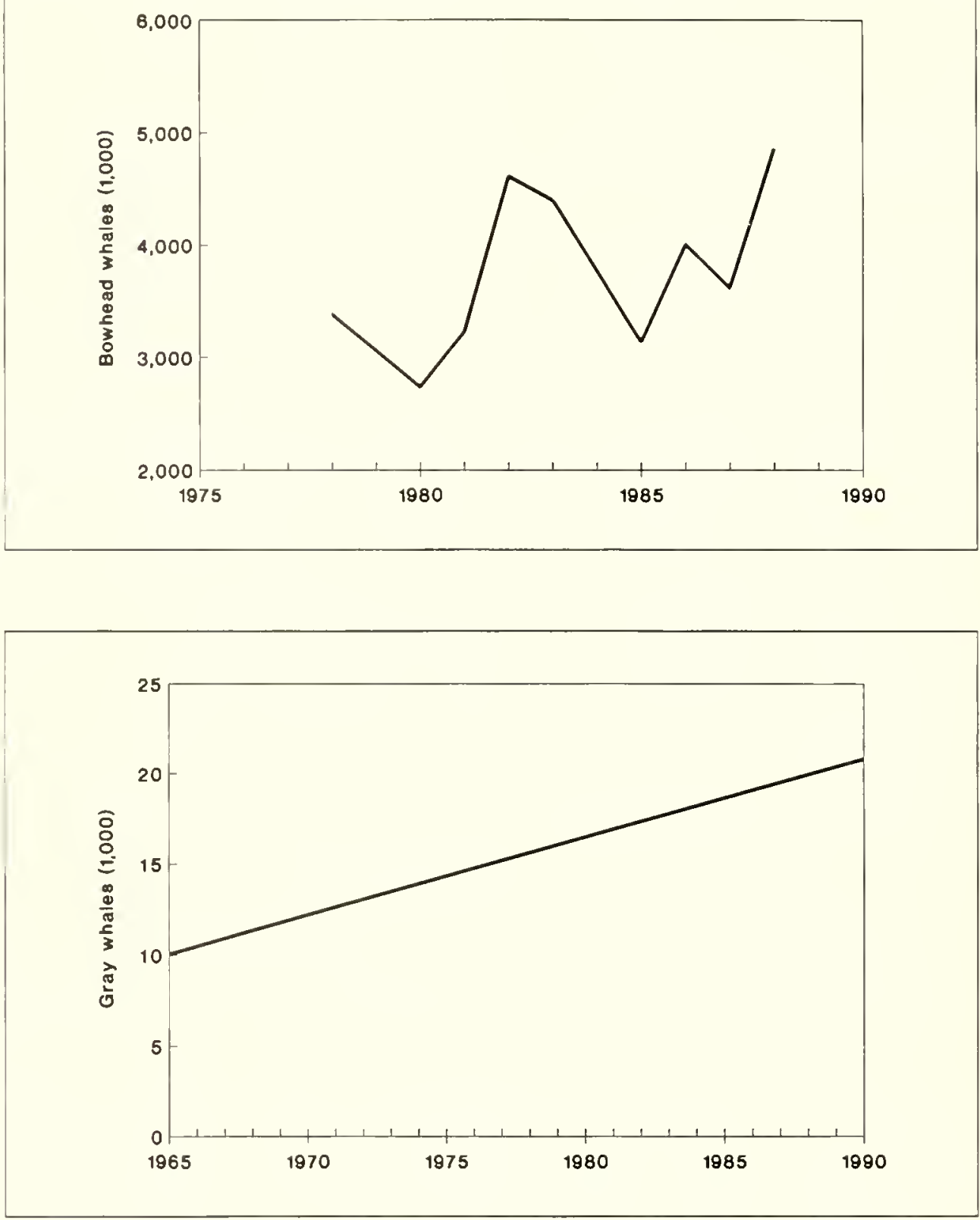

\section{Northern Sea Lion}

The northern or Steller sea lion, classified as threatened under the ESA, ranges coastal waters of the North Pacific Ocean from California to Japan. The species has declined sharply throughout its range in just the last 20 years, and is now well below its optimum level. The number of adults and juveniles in U.S. waters crashed from 154,000 in 1960 to 42,000 in 1990. Most of this $73 \%$ decline occurred in Alaska waters, where sea lion counts at three study sites were 105,289 in $1959 ; 89,364$ in 1976; 55,824 in 1985; and 23,000 in 1990 (Fig. 23-3). The decline in Alaska is believed to be due to a combination of incidental kills in fisheries, illegal shooting. changes in the numbers and/or quality of prey, and possibly other unidentified factors. (The Steller sea lion population off Washington and Oregon is low but stable at about 3,000, but in California they have slowly declined since the 1950's to about 2,000.) 
Figure 23-3.-Estimated U.S. population of Steller sea lions and population trends in Alaska, 1960-90.

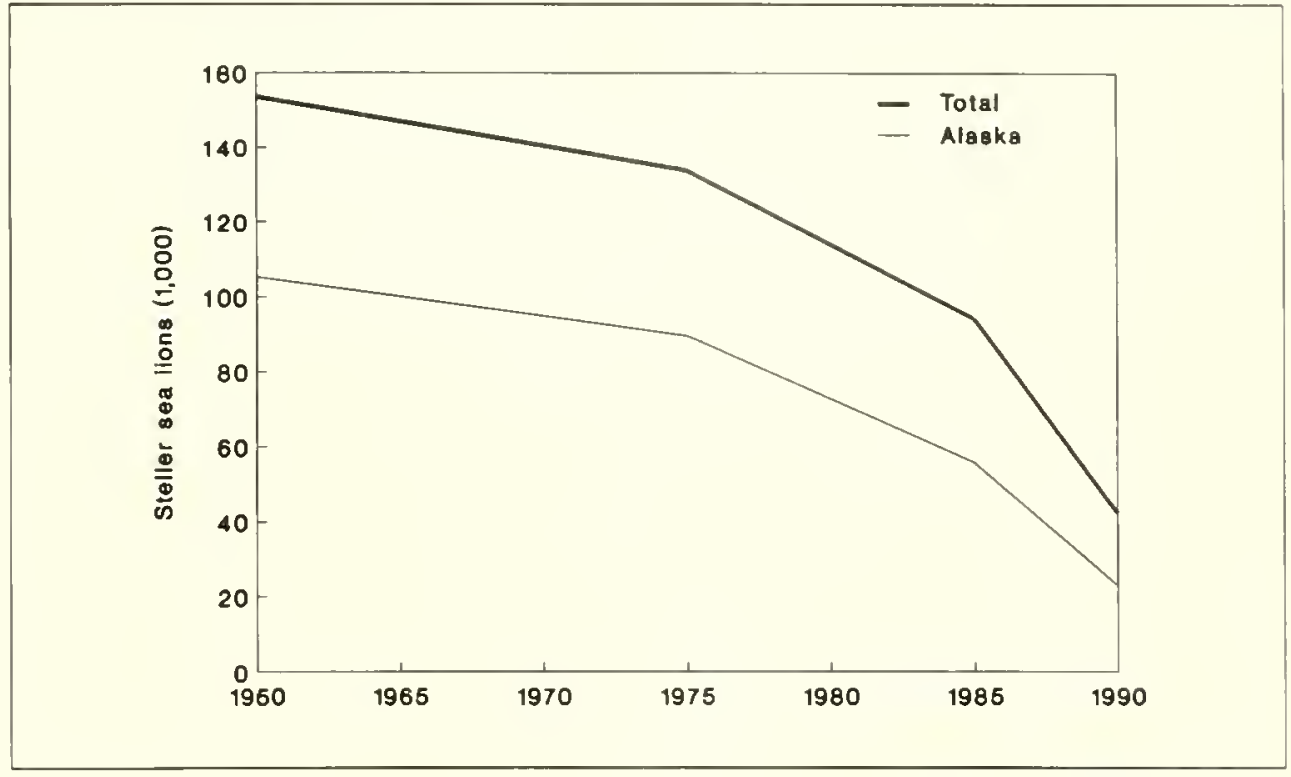

\section{Northern Fur Seal}

Figure 23-4.-Northern fur seal pup counts on St. Paul and St. George Islands, Alaska, 1970-90.
The northern fur seal of the North Pacific Ocean, considered depleted under the MMPA, ranges across subarctic Pacific Rim waters from California to Japan. It numbered 1.2 million in 1983 with 871,000 in U.S. waters. The major U.S. breeding population is on Alaska's Pribilof Islands of St. Paul and St. George. Production on the Pribilof Islands dropped more than 60\% between 1955 and 1980, but has since been stable. On St. George Island, production has continued to decline about 6\%/year since 1970 (Fig. 23-4). Small (I.S. breeding populations are also found on Alaska's Bogoslof Island (1,500), and California's San Miguel Island $(4,000)$. The Pribilof Islands' fur seal carrying capacity has changed little since the 1950's.

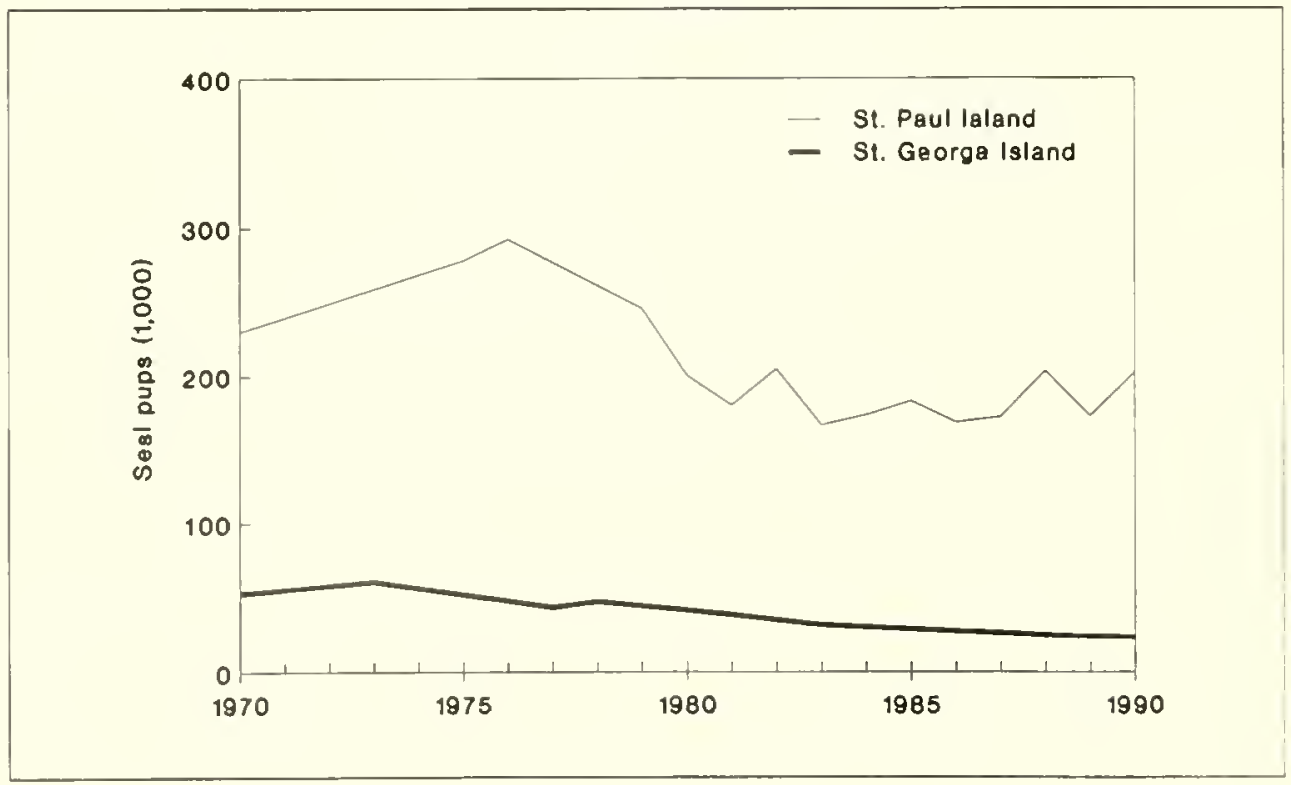




\section{California sea Lion}

Figure 23-5.-California sea lion pup counts on the Channel Islands, 1971-86.
The California sea lion has three subspecies living on the U.S. west coast and British Columbia, in the Galapagos Islands, and in Japan. Between Mexico and British Columbia the population, about 157,000 animals, has grown about $6 \% /$ year since the 1970's (Fig. 23-5). Annual production of 16,000-17,000 pups on the California Channel Islands in 1986 corresponds to a population size of about 87,000 animals. The California population in 1982 (prior to the 1982-83 El Niño warm water intrusion) was thought to be near or slightly below the lower end of its optimum population.

\section{Harbor seal}

Considered endangered under the ESA, the monk seal is limited to the small islands and atolls of the 1,100-mile Hawaiian Archipelago. The total population is about 1,500 animals, a $60 \%$ decline since 1958 . The monk seals at French Frigate Shoals have increased a bit recently. Average counts of the five major breeding sites increased from 468 to 639 during 1983-87 but dropped to 546 in 1990. Production increased during 1983-88 but dropped $23 \%$ in 1990 from the $1983-88$ average (Fig. 23-6). 
Figure 23-6.--Hawaiian monk seal live births, 1983-90.

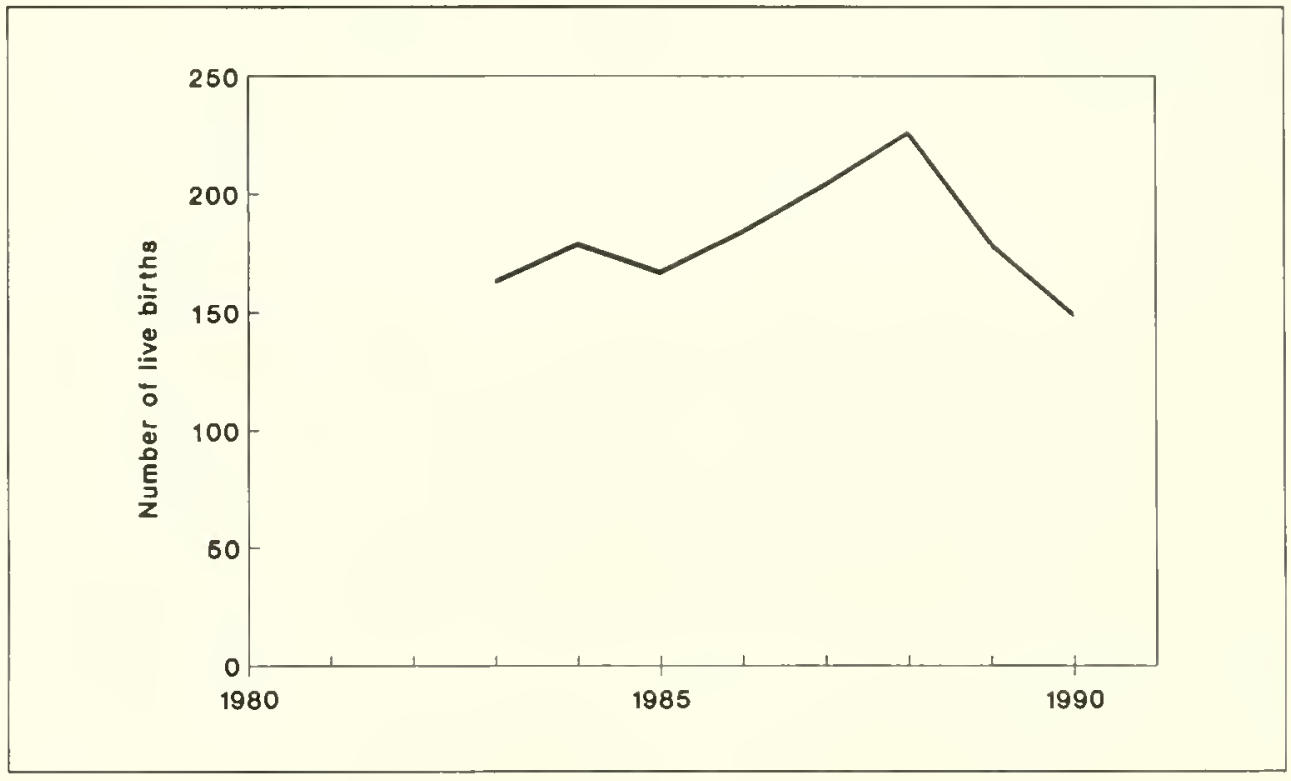

ISSUES
Important management issues are: 1) Have fisheries interactions and other human-related activities directly harmed marine mammals or significantly altered the carrying capacity of the marine ecosystem for them; 2) are the depleted marine mammals recovering, and have the best steps been taken to speed their recovery; and 3) what actions are necessary to minimize potential conflicts between the ESA, MMPA, MFCMA, and other Federal laws on marine resources and fisheries management?

\section{Fisheries Interactions}

One issue involves competition for food. U.S. and foreign commercial fisheries have been operating in the eastern North Pacific for more than 100 years and fish catches have been sustained there for many decades. Some fish populations, however, have collapsed and are no longer commercially viable. The impact of removing millions of fish and shellfish from the marine ecosystem each year on the marine mammals that also eat them is, however, unknown.

Accidental killing of marine mammals is another concern. Except for the northern spotted dolphin, the dolphin kill in the eastern tropical Pacific tuna fishery has declined drastically since the 1960 's. Monitoring must continue, to see if the dolphin populations increase. The current accidental annual kill of northern spotted dolphin $(36 \%)$ will have to decrease for the population to rebound.

The harbor porpoise kill in California's fisheries declined from 200-300/year in the mid-1980's to less than 100/year after gillnet fishing ceased. The harbor porpoise kill by the Makah Indian tribal setnet salmon fishery off the north coast of Washington declined from over 100 in 1987-88 to 13 in 1990 when fishing effort was reduced.

The known kill of Steller sea lions in Alaska fisheries has declined from over 1,400 in 1982 to 23 in 1990. The numbers killed in other fisheries is believed to be even smaller. Harbor seals are killed in low numbers, but data are incomplete.

Observed marine mammal kills in the foreign high-seas squid fishery in 1989 numbered 455 northern right whale dolphins, 254 white-sided dolphins, 208 fur seals, 141 Dall porpoises, 10 common dolphins, and 52 unidentified dolphins (only $4 \%$ of the fishery was monitored). One fur seal was reported killed in U.S. fisheries in 1990. 
Recovery of Protected species
Eleven U.S. west coast marine mammal species are listed as endangered or threatened under the ESA. Though the data are limited, right whales in the eastern North Pacific Ocean are at a critically low level: Only 5-7 sightings have been made in the past 25 years. There are far too few data on other species, such as blue and humpback whales, to judge whether any recovery is taking place. Some human activities may, however, be affecting the recovery of some species. For example, adult female humpback whales with calves have apparently been abandoning traditional nearshore calving and calf rearing habitat near Maui, Hawaii, owing to repeated human interference or contact. Recovery plan action will provide a way to gauge progress in the restoration of endangered and threatened resources.

\section{Conservation and} Fisheries Management conflicts
Some pinniped populations, such as Steller sea lion, northern fur seal, and harbor seal, have declined in the last 20 years. During the same period, other pinniped populations farther south along the west coast have increased, such as harbor seal, California sea lion, northern fur seal, and northern elephant seal. Growing marine mammal populations will raise different fishery management concerns. For one, fisheries management actions and the MFCMA may be in conflict with protective requirements of the MMPA and ESA, as when marine mammals prey on depleted fish stocks, like Pacific salmon, or if they are in turn accidentally killed in fishing operations. The biological information needed to assess and manage these problems is generally lacking. 


\section{INTRODUCTION}

Table 24-1.-Annual number of female sea turtles nesting on U.S. beaches.
Sea turtles are highly migratory and ply the world's oceans. Under the Endangered Species Act of 1973, all marine turtles are listed as endangered or threatened (Table 24-1). The NMFS has authority to protect and conserve marine turtles in the seas and the U.S. Fish and Wildlife Service maintains authority while turtles are on land.
The Kemp's ridley, hawksbill, and leatherback turtles are listed as endangered throughout their ranges. The loggerhead and olive ridley turtles are listed as threatened throughout their U.S. ranges, as is the green turtle, except the Florida nesting population which is listed as endangered.

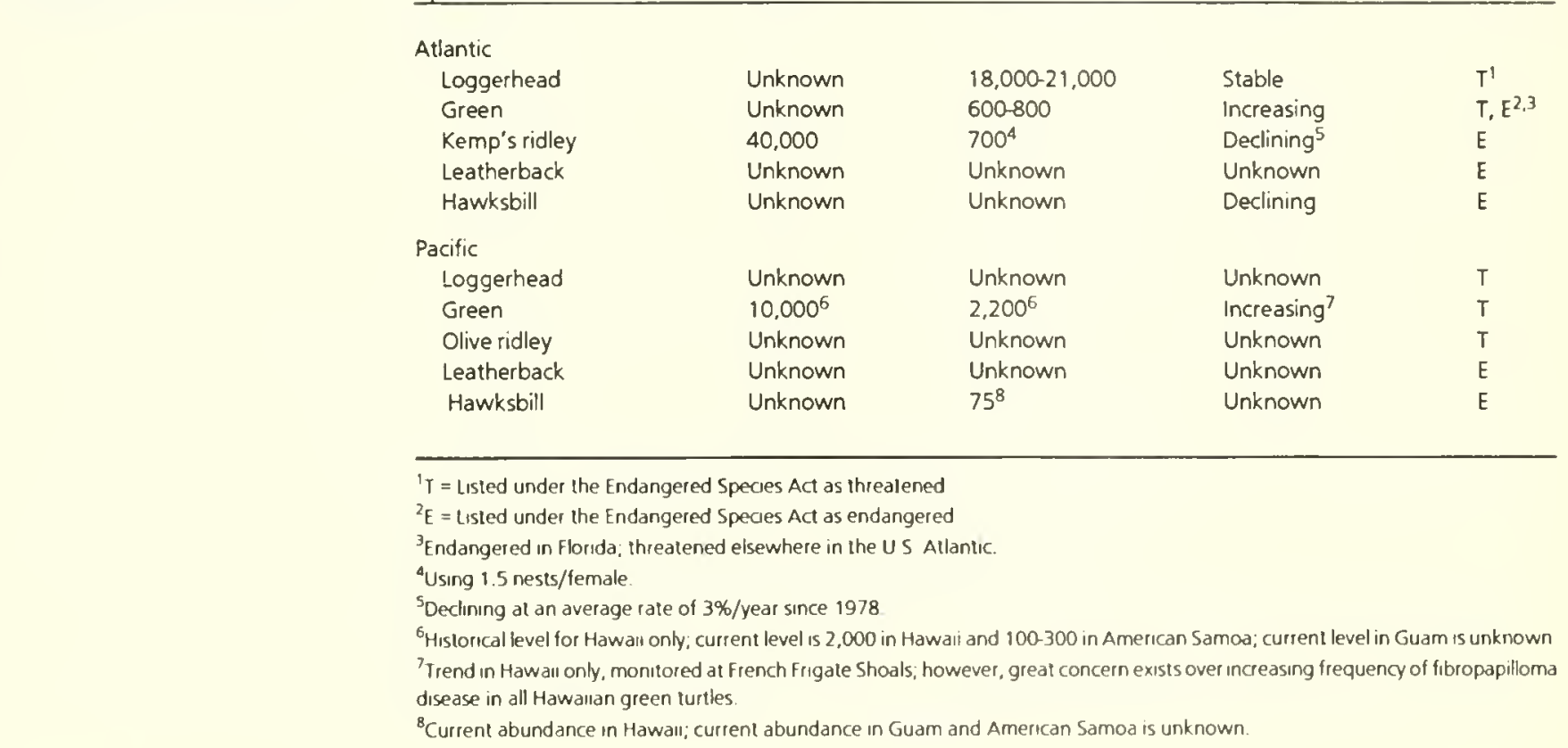

\section{SPECIES AND STATUS}

The six Pacific species are loggerhead, green, Kemp's ridley, leatherback, hawksbill, and olive ridley turtles. All six are also found in the Atlantic Ocean, but the olive ridley does not enter U.S. waters. In Hawaiian waters, the green and hawksbill are most abundant. Off the U.S. west coast, the loggerhead, leatherback, and olive ridley turtles are most commonly reported.

Historical data on sea turtle numbers are limited. In addition, the length of time that data have been collected has been short when compared with the long life and low reproductive rate of all turtle species. It is difficult to assess the long-term status of sea turtles owing to the limited data.

The 1982-84 number of loggerhead nesting females from North Carolina to Florida was 18,000-21,000 (Table 24-1). Most nest along Florida's east coast where nest numbers have been stable for five years. Only about 700 female Kemp's ridley turtles nest along a limited portion of Mexico's Atlantic coast. In 1947, on a single day, 40,000 females were seen nesting on one beach alone. The documented decline in the Kemp's ridley is probably indicative of dropoffs for other sea turtles, though the periods of their various declines may have differed (Fig. 24-1).

Historically, the green sea turtle has supported large fisheries along the Florida and Texas coasts, although its nesting on U.S. beaches has probably always been limited. In the late 1800's, 2,000 females reportedly nested at Key West, Fla. Currently, perhaps $600-800$ green turtles nest along the Florida coast. However, it appears that the 
Figure 24-1.-Number of nesting females of Kemp's ridley sea turtles, 1945 and 1978-89.

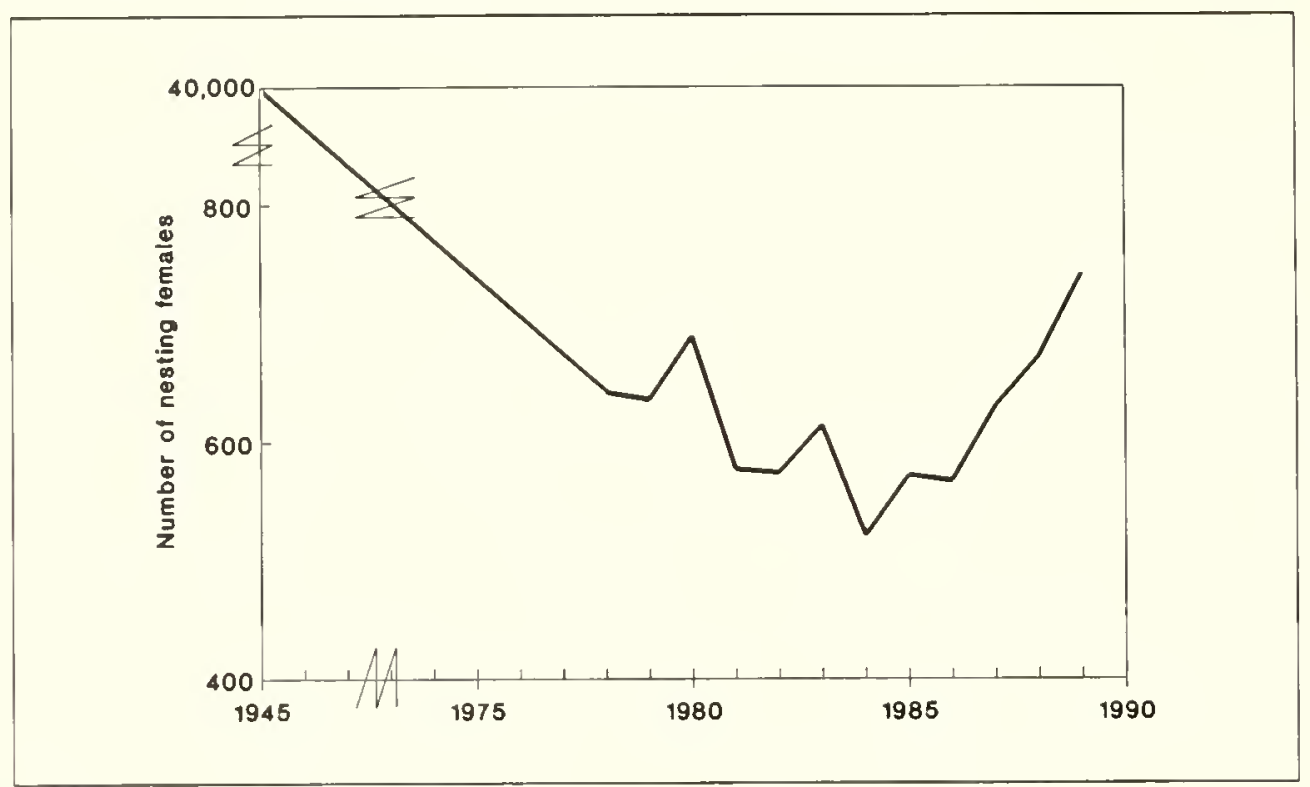

... SPECIES AND STATUS number of juvenile and subadult turtles in Florida's inshore waters has recently returned to historic levels. There are no historical estimates for the numbers of hawksbill or leatherback turtles nesting on U.S. Caribbean beaches. The hawksbill has been heavily exploited, and continued trade of products from this species suggests that further declines are possible. The trend over time of the leatherback turtle in U.S. waters is unknown.

Since 1973, Hawaiian surveys of nesting green turtles indicate that the adult population may currently number about 2,000 and that it is gradually increasing. No accurate historical record of green turtle populations exists. Despite an apparent increase in the nesting population, there is growing concern that fibropapilloma disease, which has infected green turtles of all ages in many inshore feeding and resting areas, may seriously curtail population recovery. The Hawaiian hawksbill turtle population is very small; only $12-15$ nests are recorded each year. In Hawaii, little is known of the species' reproductive biology or population trends.

\section{ISSUES}

In the North Pacific there are concerns about sea turtle deaths in the high-seas driftnet fisheries. Turtle bycatch rates are being monitored on driftnet vessels by U.S., Canadian, Japanese, Korean, and Taiwanese scientific observers. The effect of these driftnet fisheries on U.S. sea turtle populations is unknown. Turtles are also killed when accidentally caught in other fisheries. As many as 10,000 sea turtles may be taken annually in shrimp trawls. Turtle excluder devices (TED's) have been developed and, when attached to shrimp trawls, enhance turtle safety by releasing them. TED's reduce the turtle kill by shrimp trawls by $97 \%$, and their use is mandated for certain shrimp fishing areas. Studies indicate that the use of TED's has reduced shrimp catches only about $5-15 \%$. Shrimpers are concerned about reduced income owing to lower shrimp catches.

Sea turtles are fully protected in U.S. waters, but their habitats continue to be hurt. Coastal development is reducing nesting, nursery, and foraging habitats. Floating tar balls and plastics, if eaten, can harm or kill sea turtles. The magnitude of these problems is not fully known, but they occur worldwide, and international cooperation for marine turtle protection and recovery is needed. 
o Part 3: APPENDICES 

The following National Marine Fisheries Service scientists, listed alphabetically, assisted in writing this report: Frank Almeida, Vaughn Anthony, George Balazs, Jay Barlow, Norman Bartoo, Christofer Boggs, James Bohnsack, Howard Braham, John Brodziak, Joan Browder, Steven Clark, Darryl Christensen, George Darcy, Edward DeMartini, Douglas DeMaster, Steve Edwards, Kevin Friedland, Wendy Gabriel, William Gilmartin, Christopher Gledhill, Phillip Goodyear, Daniel Hayes, Larry Hansen, Douglas Harper, Ken Henry, Josef lodine, Lawrence Jacobson, Robert Kope, Phil Logan, Loh-Lee Low, Sandra Lowe, Alec MacCall, Ralph Mayo, Margaret McBride, James Meehan, Rick Methot, Steven Murawski, James Nance, Jim Olsen, Bob Otto, William Overholtz, Joan Palmer, Michael Parrack, Nancie Parrack, Patricia Phares, Jeffrey Polovina, Joseph Powers, Eric Prince, Jerry Reeves, Anne Richards,
Gerald Scott, Fredric Serchuk, Gary Shepherd, Allen Shimada, Michael Sissenwine, Joyce Sisson, Robert Skillman, David Somerton, Mark Terceiro, Nancy Thompson, Steven Turner, Douglas Vaughan, Gordon Waring, Vidar Wespestad, Jerry Wetherall, Susan Wigley. Pat Sullivan of the International Pacific Halibut Commission contributed to the section on Pacific halibut.

The following personnel in the NMFS Scientific Publications Office (SPO) and Office of Research and Environmental Information (OREI) produced this report: Editors were W. L. Hobart (SPO) and James Meehan (OREI), assisted by Sharyn Matriotti and Nancy Peacock (SPO). Shelley Arenas (SPO) completed the desktop publishing with assistance from Jackie Greenawalt (OREI), Jacki Geiger (SPO), and Joni Packard (SPO). Design, layout, and the front cover art was by Harold Spiess (SPO). 


\section{AND FISHERY MANAGEMENT PLANS}

114

NEW ENGLAND FISHERY MANA GEMENT COUNCIL
American Lobster Fishery Management

Plan

Fishery Management Plan for the

Northeast Multispecies Fishery
Fishery Management Plan for Atlantic Sea Scallops

Atlantic Salmon Fishery Management Plan

\begin{tabular}{lll}
\hline MID-ATLANTIC FISHERY & Fishery Management Plan for Atlantic & Fishery Management Plan for Atlantic \\
MANAGEMENT COUNCIL & Mackerel, Squid, and Butterfish Fisheries & Bluefish \\
& Fishery Management Plan for Atlantic & Fishery Management Plan for Summer \\
& Surf Clam and Ocean Quahog Fisheries & Flounder
\end{tabular}

SOUTH ATLANTIC FISHER Y MANAGEMENT COUNCIL
Fishery Management Plan for the Snapper-Grouper Fishery of the South Atlantic Region
Atlantic Coast Red Drum Fishery

Management Plan

\section{GULF OF MEXICO FISHER Y MANAGEMENT COUNCIL}

Fishery Management Plan for the Spiny Lobster Fishery of the Gulf of Mexico and South Atlantic

Fishery Management Plan for the Stone Crab Fishery of the Gulf of Mexico

Fishery Management Plan for the Shrimp Fishery of the Gulf of Mexico

Fishery Management Plan for Coastal Migratory Pelagic Resources of the Gulf of Mexico and South Atlantic

Fishery Management Plan for Coral and Coral Reefs in the Gulf of Mexico and South Atlantic Fishery Management Plan for the Reef Fish Resources of the Gulf of Mexico

Fishery Management Plan for the Red Drum Fishery of the Gulf of Mexico

\section{CARIBBEAN FISHER Y MANAGEMENT COUNCIL \\ Fishery Management Plan for the Spiny \\ Lobster Fishery of Puerto Rico and the \\ U.S. Virgin Islands}

Fishery Management Plan for the Shallow Water Reeffish Fishery of Puerto Rico and the U.S. Virgin Islands

\section{PACIFIC FISHER Y} MANAGEMENT COUNCIL
Fishery Management Plan for the

Groundfish Fishery off Washington,

Oregon, and California

Northern Anchovy Fishery Management

Plan

\begin{abstract}
Fishery Management Plan for Commercial and Recreational Salmon Fisheries off the Coasts of Washington, Oregon, and California
\end{abstract}

\section{WESTERN PACIFIC FISHER Y MANAGEMENT COUNCIL}

Fishery Management Plan for the

Crustacean Fishery of the Western

Pacific Region

Fishery Management Plan for the

Precious Corals Fisheries of the Western

Pacific Region
Fishery Management Plan for the Bottomfish and Seamount Groundfish Fisheries of the Western Pacific Region Fishery Management Plan for the Pelagic Fisheries of the Western Pacific Region 
NORTH PACIFIC FISHERY Fishery Management Plan for Groundfish MANAGEMENT COUNCIL of the Gulf of Alaska

Fishery Management Plan for the High Seas Salmon Fishery off the Coast of Alaska East of 175 Degrees East Longitude
Fishery Management Plan for the Groundfish Fishery of the Bering Sea and Aleutian Islands Area

Bering Sea/Aleutian Islands King and Tanner Crab Fishery Management Plan
SECRETARIAL PLANS Fishery Management Plan for Atlantic Swordfish
Fishery Management Plan for Atlantic Billfishes 
UNIT 1: NORTHEAST DEMERSAL FISHERIES
Principal Groundfish and Flounders

Atlantic cod, Gadus morhua

Haddock, Melanogrammus aeglefinus

Pollock, Pollachius virens

Redfish, Sebastes marinus

Silver hake, Merluccius bilinearis

Red hake, Urophycis chuss

Yellowtail flounder, Limanda ferruginea

Winter flounder, Pseudopleuronectes americanus

Summer flounder, Paralichthys dentatus

Witch flounder, Glyptocephalus cynoglossus

American plaice, Hippoglossoides platessoides

Windowpane, Scophthalmus aquosus

Skates and Spiny Dogfish

Spiny dogfish, Squalus acanthias

Skates, Raja spp.
Other Finfish

White hake, Urophycis tenuis

Goosefish, Lophius americanus

Cusk, Brosme brosme

Ocean pout, Macrozoarces americanus

Sculpins, Family Cottidae

Searobins, Family Triglidae

Scup, Stenotomus chrysops

Tilefish, Lopholatilus chamaeleonticeps

Wolffishes, Anarhichas spp.

Atlantic argentine, Argentina silus

Black sea bass, Centropristis striata

Smooth dogfish, Mustelus canis

Spot, Leiostomus xanthurus

Weakfish, Cynoscion regalis

Atlantic halibut, Hippoglossus

hippoglossus
UNIT 2: NORTHEAST PELAGIC FISHERIES
Atlantic (sea) herring, Clupea harengus

Atlantic mackerel, Scomber scombrus

Butterfish, Peprilus triacanthus
Bluefish, Pomatomus saltatrix

Long-finned squid, Loligo pealei

Short-finned squid, Illex illecebrosus

\section{UNIT 3: ATLANTIC \\ ANADROMOUS FISHERIES}

\section{Atlantic salmon, Salmo salar}

American shad, Alosa sapidissima

River herring (alewife), Alosa

pseudoharengus
Striped bass, Morone saxatilis

Atlantic sturgeon, Acipenser

oxyrhynchus

\section{UNIT 4: NORTHEAST INVERTEBRATE FISHERIES}

Sea scallop, Placopecten magellanicus American lobster, Homarus americanus Surf clam, Spisula solidissima
Ocean quahog, Arctica islandica Northern shrimp, Pandalis borealis

\section{UNIT 5: ATLANTIC HIGHLY MIGRATORY PELAGIC FISHERIES}

\footnotetext{
'Speoes are listed by the Unit in which they are lound. Not all are mentioned in the text since many are grouped together for managemenl purposes under one category (i e, pelagic fishery, groundfish fishery).
}

\author{
Atlantic swordfish, Xiphias gladius \\ Billfishes \\ Sailfish, Istiophorus platypterus \\ Blue marlin, Makaira nigricans \\ White marlin, Tetrapturus albidus \\ Longbill spearfish, Tetrapturus \\ pluegeri \\ Atlantic bluefin tuna, Thunnus \\ thynnus
}
Other Tunas
Albacore, Thunnus alalunga
Bigeye tuna, Thunnus obesus
Blackfin tuna, Thunnus atlanticus
Yellowfin tuna, Thunnus albacares
Little tunny, Euthynnus alletteratus
Skipjack tuna, Euthynnus pelamis
Bullet tuna, Auxis rochei
Frigate tuna, Auxis thazard


UNIT 6: ATLANTIC SHARK FISHERIES
Pelagic Sharks

Thresher shark, Alopias vulpinus

Bigeye thresher, Alopias superciliosus

Oceanic whitetip shark, Carcharhinus

longimanus

Sevengill shark, Heptrachias perlo

Sixgill shark, Hexanchus griseus

Bigeye sixgill shark, Hexanchus vitulus

Shortfin mako, Isurus oxyrinchus

Longfin mako, Isurus paucus

Porbeagle, Lamna nasus

Blue shark, Prionace glauca

Large Coastal Sharks

Sandbar shark, Carcharhinus plumbeus

Reef shark, Carcharhinus perezi

Blacktip shark, Carcharhinus limbatus

Dusky shark, Carcharhinus obscurus

Spinner shark, Carcharhinus brevipinna

Silky shark, Carcharhinus falciformis

Bull shark, Carcharhinus leucas

Bignose shark, Carcharhinus altimus

Galapagos shark, Carcharhinus galapagensis
Night shark, Carcharhinus signatus

White shark, Carcharodon charcharias

Basking shark, Cetorhinus maximus Tiger shark, Galeocerdo cuvieri

Nurse shark, Ginglymostoma cirratum

Lemon shark, Negaprion brevirostris

Ragged-tooth shark, Odontaspis ferox

Whale shark, Rhincodon typus

Scalloped hammerhead, Sphyrna lewini

Great hammerhead, Sphyrna mokarran

Smooth hammerhead, Sphyrna zygaena

Small Coastal Sharks

Finetooth shark, Carcharhinus isodon

Blacknose shark, Carcharhinus acronotus

Atlantic sharpnose shark, Rhizoprionodon terraenovae

Caribbean sharpnose shark. Rhizoprionodon porosus

Bonnethead, Sphyrna tiburo

Atlantic angel shark, Squatina dumerili

Cobia, Rachycentron canadum

Cero (mackerel), Scomberomorus regalis

Dolphin, Coryphaena hippurus

\section{UNIT 8: ATLANTIC/GULF OF MEXICO/CARIBBEAW REEF FISH FISHERIES}

Black snapper, Apsilus dentatus Queen snapper, Etelis oculatus Mutton snapper, Lutjanus analis Schoolmaster, Lutjanus apodus Blackfin snapper, Lutjanus buccanella Red snapper, Lutjanus campechanus Cubera snapper, Lutjanus cyanopterus Gray snapper, Lutjanus griseus Mahogany snapper, Lutjanus mahogoni Dog snapper, Lutjanus jocu Lane snapper, Lutjanus synagris

Silk snapper, Lutjanus vivanus Yellowtail snapper, Ocyurus chrysurus

Vermilion snapper, Rhomboplites aurorubens

Wenchman, Pristipomoides aquilonaris Voraz, Pristipomoides macrophthalmus Bank sea bass, Centropristis ocyurus

Rock sea bass, Centropristis philadelphica

Black sea bass, Centropristis striata
Dwarf sand perch, Diplectrum bivitlatum

Sand perch, Diplectrum formosum

Rock hind, Epinephelus adscensionis

Graysby, Epinephelus cruentatus

Speckled hind, Epinephelus drummondhayi

Yellowedge grouper, Epinephelus Ravolimbatus

Coney, Epinephelus fulvus

Red hind, Epinephelus guttatus

Jewfish, Epinephelus itajara

Red grouper, Epinephelus morio

Misty grouper, Epinephelus mystacinus

Warsaw grouper, Epinephelus nigrilus

Snowy grouper, Epinephelus niveatus

Nassau grouper, Epinephelus striatus

Black grouper, Mycleroperca bonaci

Yellowmouth grouper, Mycteroperca interstitialis

Gag, Mycteroperca microlepis 


\section{... ATLANTIC/GULF OF MEXICO/CARIBBEAN REEF FISH FISHERIES}

Scamp, Mycteroperca phenax

Tiger grouper, Mycteroperca tigris

Yellowfin grouper, Mycteroperca venenosa

Wreckfish, Polyprion americanus

Sheepshead, Archosargus probatocephalus

Sea bream, Archosargus rhomboidalis

Grass porgy, Calamus arctifrons

Jolthead porgy, Calamus bajonado

Saucereye porgy, Calamus calamus

Whitebone porgy, Calamus leucosteus

Knobbed porgy, Calamus nodosus

Sheepshead porgy, Calamus penna

Pluma, Calamus pennatula

Littlehead porgy, Calamus proridens

Pinfish, Lagodon rhomboides

Red porgy, Pagrus pagrus

Longspine porgy, Stenotomus caprinus

Scup, Stenotomus chrysops

Black margate, Anisotremus surinamensis

Porkfish, Anisotremus virginicus

Margate, Haemulon album

Tomtate, Haemulon aurolineatum

Smallmouth grunt, Haemulon chrysargyreum

French grunt, Haemulon flavolineatum

Spanish grunt, Haemulon macrostomum

Cottonwick, Haemulon melanurum

Sailors choice, Haemulon parrai

White grunt, Haemulon plumieri

Bluestriped grunt, Haemulon sciurus

Pigfish, Orthopristis chrysoptera

Goldface tilefish, Caulolatilus chrysops

Blackline tilefish, Caulolatilus cyanops

Anchor tilefish, Caulolatilus intermedius

Blueline (grey) tilefish, Caulolatilus microps

Tilefish (golden), Lopholatilus chamaeleonticeps

Sand tilefish, Malacanthus plumieri

Gray triggerfish, Balistes capriscus

Queen triggerfish, Balistes vetula

Ocean triggerfish, Canthidermis suffamen

Black durgon, Melichthys niger

Sargassum triggerfish, Xanthichthys ringens

Spanish hogfish, Bodianus rufus

Hogfish, Lachnolaimus maximus
Puddingwife, Halichoeres radiatus

Pearly razorfish, Hemipteronotus novacula

Yellow jack, Caranx bartholomaei

Blue runner, Caranx crysos

Crevalle jack, Caranx hippos

Horse-eye jack, Caranx latus

Black jack, Caranx lugubris

Bar jack, Caranx ruber

Greater amberjack, Seriola dumerili

Lesser amberjack, Seriola fasciata

Almaco jack, Seriola rivoliana

Squirrelfish, Holocentrus adscensionis

Longspine squirrelfish, Holocentrus rufus

Yellow goatfish, Mulloidichthys martinicus

Spotted goatfish, Pseudopeneus maculatus

Foureye butterflyfish, Chaetodon capistratus

Spotfin butterflyfish, Chaetodon ocellatus

Banded butterflyfish, Chaetodon striatus Queen angelfish, Holacanthus ciliaris

Rock beauty, Holacanthus tricolor

Gray angelfish, Pomacanthus arcuatus

French angelfish, Pomacanthus paru

Midnight parrotfish, Scarus coelestinus

Blue parrotfish, Scarus coeruleus

Striped parrotfish, Scarus croicensis

Rainbow parrotfish, Scarus quacamaia

Princess parrotfish, Scarus taeniopterus

Queen parrotfish, Scarus vetula

Redband parrotfish, Sparisoma aurofrenatum

Redtail parrotfish, Sparisoma chrysopterum

Stoplight parrotfish, Sparisoma viride

Ocean surgeonfish, Acanthurus chirurgus

Doctorfish, Acanthurus bahianus

Blue tang, Acanthurus coeruleus

Spotted trunkfish, Lactophrys bicaudalis

Honeycomb cowfish, Lactophrys polygonia

Scrawled cowfish, Laclophrys quadricornis

Trunkfish, Lactophrys trigonus

Smooth trunkfish, Lactophrys triqueter 


\section{UNIT 9: SOUTHEAST DRUM AND CROAKER FISHERIES}

Red drum, Sciaenops ocellatus Spotted seatrout, Cynoscion nebulosus Silver seatrout, Cynoscion nothus Sand seatrout, Cynoscion arenarius Spot, Leiostomus xanthurus Atlantic croaker, Micropogonias undulatus
Black drum, Pogonias cromis

Southern kingfish, Menticirrhus americanus

Gulf kingfish, Menticirrhus littoralis

Northern kingfish, Menticirrhus saxatilis
UNIT 10: SOUTHEAST
MENHADEN AND
BUTTERFISH FISHERIES

Atlantic menhaden, Brevoortia tyrannus

Gulf menhaden, Brevoortia patronus
Gulf butterfish, Peprilus burti

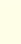

\section{UNIT 11: SOUTHEAST/ \\ CARIBBEAN INVER- TEBR ATE FISHERIES}

Spiny Lobsters/Stone Crabs Spiny lobster (SE/Caribbean), Panulirus argus

Slipper lobster, Scyllarides nodifer

Stone crab, Menippe mercenaria

Shrimp

Brown shrimp, Penaeus azlecus

White shrimp, Penaeus setiferus
Pink shrimp, Penaeus duorarum

Royal red shrimp, Hymenopenaeus robustus

Seabobs, Xiphopenaeus kroyeri

Rock shrimp, Sicyonia brevirostris

Others

Queen conch, Strombus gigas

Corals

\begin{abstract}
UNIT 12: PACIFIC
COAST SALMON

FISHERIES
\end{abstract}

Chinook salmon, Oncorhynchus tshawytscha

Coho salmon, Oncorhynchus kisutch
Pink salmon, Oncorhynchus gorbuscha Sockeye salmon, Oncorhynchus nerka Chum salmon, Oncorhynchus keta
UNIT 13: ALASKA
SALMON FISHERIES
Chinook salmon, Oncorhynchus tshawytscha

Coho salmon, Oncorhynchus kisutch
Pink salmon, Oncorhynchus gorbuscha Sockeye salmon, Oncorhynchus nerka

Chum salmon, Oncorhynchus keta

\section{UNIT 14: PACIFIC COAST AND ALASKA PELAGIC FISHERIES}

Northern anchovy, Engraulis mordax

Pacific herring (Alaska), Clupea harengus pallasi
Pacific (California) sardine, Sardinops
sagax
Jack mackerel, Trachurus symmetricus

\section{UNIT 15: PACIFIC COAST GROUNDFISH FISHERIES}

\section{Pacific hake (whiting), Merluccius productus}

Sablefish, Anoplopoma fimbria Dover sole, Microstomus pacificus

Thornyheads

Shortspine thornyhead, Sebastolobus alascanus
Longspine thornyhead, Sebastolobus altivelis

Rockfish

Aurora rockfish, Sebastes aurora

Bank rockfish, Sebastes rufus

Black-and-yellow rockfish, Sebastes chrysomelas 
... PACIFIC COAST GROUNDFISH FISHERIES
Rockfish (cont.)

Blackgill rockfish, Sebastes melanostomus

Blue rockfish, Sebastes mystinus

Bocaccio, Sebastes paucispinis

Bronzespotted rockfish, Sebastes gilli

Brown rockfish, Sebastes auriculatus

Calico rockfish, Sebastes dalli

Canary rockfish, Sebasles pinniger

Chilipepper, Sebastes goodei

China rockfish, Sebastes nebulosus

Copper rockfish, Sebastes caurinus

Cowcod, Sebastes levis

Darkblotched rockfish, Sebastes crameri

Dusty rockfish, Sebastes ciliatus

Flag rockfish, Sebastes rubrivinctus

Gopher rockfish, Sebastes carnatus

Grass rockfish, Sebastes rastrelliger

Greenblotched rockfish, Sebastes rosenblatti

Greenspotted rockfish, Sebastes chlorostictus

Greenstriped rockfish, Sebastes elongatus

Harlequin rockfish, Sebastes variegatus

Honeycomb rockfish, Sebastes umbrosus

Kelp rockfish, Sebastes atrovirens

Mexican rockfish, Sebastes macdonaldi

Olive rockfish, Sebastes serranoides

Pacific ocean perch, Sebastes alutus

Pink rockfish, Sebastes eos

Quillback rockfish, Sebastes maliger

Redbanded rockfish, Sebastes babcocki

Redstripe rockfish, Sebastes proriger

Rosethorn rockfish, Sebastes helvomaculatus

Rosy rockfish, Sebastes rosaceus

Rougheye rockfish, Sebastes aleutianus

Sharpchin rockfish, Sebastes zacentrus

Shortbelly rockfish, Sebastes jordani

Silvergray rockfish, Sebastes brevispinis

Speckled rockfish, Sebastes ovalis

Splitnose rockfish, Sebastes diploproa

Squarespot rockfish, Sebastes hopkinsi

Stripetail rockfish, Sebastes saxicola

Tiger rockfish, Sebastes nigrocinctus

Treefish, Sebastes serriceps

Vermilion rockfish, Sebastes miniatus

Widow rockfish, Sebastes entomelas

Yelloweye rockfish, Sebastes ruberrimus

Yellowmouth rockfish, Sebastes reedi

Yellowtail rockfish, Sebastes flavidus

Other Flatfishes

Arrowtooth flounder, Atheresthes stomias

Butter sole, Pleuronectes isolepis

English sole, Pleuronectes vetulus

Flathead sole, Hippoglossoides elassodon

Pacific sanddab, Citharichthys sordidus

Petrale sole, Eopsetta jordani

Rex sole, Errex zachirus

Rock sole, Pleuronectes bilineata

Sand sole, Psettichthys melanostictus

Starry flounder, Platichthys stellatus

Others

Leopard shark, Triakis semifasciata

Soupfin shark, Galeorhinus zyopterus

Spiny dogfish, Squalus acanthias

Big skate, Raja binoculata

California skate, Raja inornata

Longnose skate, Raja rhina

Spotted ratfish, Hydrolagus colliei

Finescale codling, Antimora microlepis

Pacific rattail, Coryphaenoides acrolepis

Cabezon, Scorpaenichthys marmoratus

Kelp greenling, Hexagrammos decagrammus

Lingcod, Ophiodon elongatus

Pacific cod, Gadus macrocephalus

California scorpionfish, Scorpaena guttata
UNIT 16: WESTERN PACIFIC INVERTEBRATE FISHERIES
Spiny lobster, Panulirus marginatus

Slipper lobster, Panulirus penicillatus
Precious corals, Family Scyllaridae 


\section{UNIT 17: WESTERN PACIFIC BOTTOMFISH AND ARMORHEAD FISHERIES}

Reef Fishes

Silverjaw jobfish, Aphareus rutilans

Gray jobfish, Aprion virescens

Squirrelfish snapper, Etelis carbunculus

Longtail snapper, Etelis coruscans

Bluestripe snapper, Lutjanus kasmira

Yellowtail snapper, Pristipomoides auricilla

Pink snapper, Pristipomoides filamentosus

Yelloweye snapper, Pristipomoides Ravipinnus

Snapper, Pristipomoides sieboldii. Pristipomoides zonatus

Giant trevally, Caranx ignoblis
Black jack, Caranx lugubris

Thick lipped trevally, Pseudocaranx dentex

Amberjack, Seriola dumerili

Blacktip grouper, Epinephelus fasciatus

Seabass, Epinephelus quernus

Lunartail grouper, Variola louti

Ambon emperor, Lethrinus amboinensis

Redgill emperor, Lethrinus rubrioperculatus

Seamount Fishes

Armorhead, Pentaceros richardsoni

Alfonsin, Beryx splendens

Raftish, Hyperoglyphe japonica

\section{UNIT 18: PACIFIC HIGHLY MIGRATOR Y PELAGIC FISHERIES}

\section{Swordfish, Xiphias gladius}

Blue marlin, Makaira nigricans

Striped marlin, Tetrapturus audax

Albacore (North $\&$ South), Thunnus alalunga

Bigeye tuna, Thunnus obesus

Yellowfin tuna, Thunnus albacares

Other Pelagics

Sailfish, Istiophorus platypterus

Black marlin, Makaira indica
Shortbill spearfish, Tetrapturus angustirostris

Dolphin (mahimahi), Coryphaena hippurus

Pompano dolphin, Coryphaena equisetis

Oceanic sharks, FamiliesCarcharhinidae, Alopiidae, Sphyrnidae, and Lamnidae Wahoo, Acanthocybium solanderi

\section{UNIT 19: ALASKA} GROUNDFISH FISHERIES
Walleye (Alaska) pollock, Theragra chalcogramma

Pacific cod, Gadus macrocephalus

Sablefish, Anoplopoma fimbria

Yellowfin sole, Pleuronectes asper

Pacific halibut, Hippoglossus stenolepis

Other Flatfishes

Arrowtooth flounder, Atheresthes stomias

Greenland halibut, Reinhardtius hippoglossoides

Rock sole, Pleuronectes bilineata

Flathead sole, Hippoglossoides elassodon

Alaska plaice, Pleuronectes quadrituberculatus

Rex sole, Errex zachirus

Butter sole, Pleuronectes isolepis

Longhead dab, Pleuronectes proboscidens

Dover sole, Microstomus pacificus

Starry flounder, Platichthys stellatus

Rockfishes

Pacific ocean perch, Sebastes alutus
Thornyhead rockfish, Sebastolobus spp.

Rougheye rockfish, Sebastes aleutianus

Dusky rockfish, Sebastes ciliatus

Northern rockfish, Sebastes polyspinis

Shortspine thornyhead, Sebastes alascanus

Shortraker rockfish, Sebastes borealis

Darkblotched rockfish, Sebastes crameri

Sharpchin rockfish, Sebastes zacentrus

Yelloweye rockfish, Sebastes ruberrimus

Blue rockfish, Sebastes mystinus Others

Atka mackerel, Pleurogrammus monopterygius

Rattail, Coryphaenoides sp.

Skates, Raja spp.

Squids, Sepioid and Teuthoid

Octopus, Octopoda 
UNIT 20. ALASKA SHELLFISH FISHERIES
King crabs

Red king crab, Paralithodes camtschatica

Blue king crab, Paralithodes platypus

Golden (brown) king crab, Lithodes aequispina

Tanner crabs, Chioneceles bairdi, Chionecetes opilio

Sea Snails, Neptunea pribiloffensis,
Neptunea heros, Neptunea lyrata, Neptunea ventricosa, Neptunea oregonensis, Buccinum angulossum, Buccinum plectrum, Buccinum scalariforme, Buccinum polare, Volutopsius middindorffii, Volutopsius fragilis, Plicifusus kroyeri, Pyrulofusus deformis

\section{UNIT 21. NEARSHORE RESOURCES}

Tarpon, Megalops atlanticus

Ladyfish, Elops saurus

Bonefish, Albula vulpes

American eel, Anguilla rostrata

Other shads, herrings, Alosa aestivalis, Alosa alabamae, Alosa mediocris, Dorosoma cepedianum, Dorosoma petenense, Etrumeus teres, Harengula clupeola, Harengula humeralis, Harengula jaguana

Atlantic thread herring, Opisthonema oglinum

Spanish sardine, Sardinella aurita Ballyhoo, Hemiramphus brasiliensis Surf smelt, Hypomesus pretiosus Eulachon, Thaleichthys pacificus

Common snook, Centropomus undecimalis

Florida pompano, Trachinotus carolinus

Permit, Trachinotus falcalus

California corvina, Menticirrhus undulatus

Surfperches, Family Embiotocidae
Mullets, Family Mugilidae

Tautog, Tautoga onitis

Striped bass (Pacific), Morone saxatilis

Abalone, Haliotis spp.

Whelk, Busycon spp.

Periwinkle, Littorina spp.

Pacific shrimps, Family Pandalidae

Dungeness crab, Cancer magister

Rock crab, Cancer irroratus

Jonah crab, Cancer borealis

Blue crab, Callinectes sapidus

Blue mussel, Mytilus edulis

Pacific razor clam, Siliqua patula

Pismo clam, Tivela stultorum

Pacific hard clams, Family Veneridae

Atlantic hard clam, Mercenaria mercenaria

Softshell clam, Mya arenaria

Bay scallop, Argopecten irradians

Calico scallop, Argopecten gibbus

Oyster (Atlantic), Crassostrea virginica

Oyster (Pacific), Crassostrea gigas

Sea urchins, Strongylocentrotus spp.

\section{UNIT 22. ATLANTIC MARINE MAMMALS}

Right whale, Eubalaena glacialis

Humpback whale, Megaptera novaeangliae

Longfin pilot whale, Globicephala melas

Shortfin pilot whale, Globicephala macrorhynchus

Harbor porpoise, Phocoena phocoena

Bottlenose dolphin, Tursiops truncatus

Harbor seal, Phoca vitulina

\section{Other Marine Mammals}

Fin whale, Balaenoptera physalus

Whitesided dolphin, Lagenorhynchus acutus

Striped dolphin, Stenella coeruleoalba Spotted dolphin (Atlantic), Stenella plagiodon

Beaked whales, Mesoplodon spp.

\section{UNIT 23. PACIFIC MARINE MAMMALS}

\section{Eastern Tropical Pacific Porpoises} Spinner dolphin, Stenella longirostris Spotted dolphin (Pacific), Stenella attenuata

Striped dolphin, Stenella coeruleoalba Common dolphin, Delphinus delphis Bowhead whale, Balaena mysticetus Gray whale, Eschrichtius robustus Humpback whale, Megaptera novaeangliae
Northern (Steller) sea lion, Eumetopias jubalus

Northern fur seal, Callorhinus ursinus

Hawaiian monk seal, Monachus schauinslandi

California sea lion, Zalophus californianus

Other Marine Mammals Dall's porpoise, Phocoenoides dalli Harbor porpoise, Phocoena phocoena 
...PACIFIC MARINE

MAMMALS
Other Marine Mammals (cont.)

Northern right-whale dolphin, Lissodelphis borealis
Whitesided dolphin, Lagenorhynchus obliquidens

Harbor seal, Phoca vitulina
Kemp's ridley sea turtle, Lepidochelys kempi

Olive ridley sea turtle, Lepidochelys olivacea

Leatherback sea turtle, Dermochelys coriacea

Green sea turtle, Chelonia mydas

Loggerhead sea turtle, Caretta caretta

Hawksbill sea turtle, Eretmochelys

imbricala 




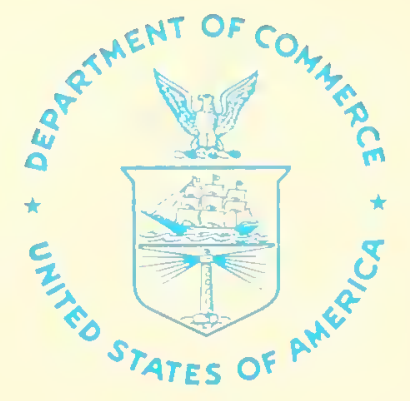

